Thiago Magri Benucci

\title{
O jeito yanomami de pendurar redes
}

Versão corrigida

Dissertação apresentada à Faculdade de Filosofia, Letras e Ciências Humanas da Universidade de São Paulo para obtenção do título de Mestre em Antropologia Social.

Área de concentração: Antropologia Social

Orientador: Prof. Dr. Pedro de Niemeyer Cesarino

São Paulo, 2020 
Autorizo a reprodução e divulgação total ou parcial deste trabalho, por qualquer meio convencional ou eletrônico, para fins de estudo e pesquisa, desde que citada a fonte.

Faculdade de Filosofia, Letras e Ciências Humanas da Universidade de São Paulo

Benucci, Thiago Magri

B456j O jeito yanomami de pendurar redes / Thiago Magri Benucci ; orientador Pedro de Niemeyer Cesarino. São Paulo, 2020.

$261 \mathrm{f}$.

Dissertação (Mestrado)- Faculdade de Filosofia, Letras e Ciếncias Humanas da Universidade de São Paulo. Departamento de Antropologia. Área de concentração: Antropologia Social.

1. Yanomami. 2. Arquitetura. 3. Casa. 4. Xamanismo. I. Cesarino, Pedro de Niemeyer, orient. II. Título. 


\section{ENTREGA DO EXEMPLAR CORRIGIDO DA DISSERTAÇÃO/TESE}

Termo de Ciência e Concordância do (a) orientador (a)

\section{Nome do (a) aluno (a): Thiago Magri Benucci}

Data da defesa: 27/11/2020

Nome do Prof. (a) orientador (a): Pedro de Niemeyer Cesarino

Nos termos da legislação vigente, declaro ESTAR CIENTE do conteúdo deste EXEMPLAR CORRIGIDO elaborado em atenção às sugestões dos membros da comissão Julgadora na sessão de defesa do trabalho, manifestando-me plenamente favorável ao seu encaminhamento e publicação no Portal Digital de Teses da USP.

São Paulo, $7 / 01 / 2021$

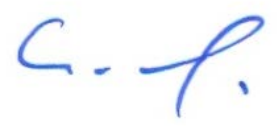


Benucci, Thiago Magri. O jeito yanomami de pendurar redes. 2020.

Dissertação de Mestrado, Programa de Pós-Graduação em Antropologia Social - Universidade de São Paulo, São Paulo.

Aprovado em: 27/11/2020

Banca Examinadora

Prof. Dr.: Pedro de Niemeyer Cesarino Instituição: Universidade de São Paulo Julgamento:

Prof. Dr.: Beatriz Perrone-Moisés Instituição: Universidade de São Paulo Julgamento:

Prof. Dr.: Guilherme Teixeira Wisnik Instituição: Universidade de São Paulo Julgamento:

Prof. Dr.: José Antonio Kelly Luciani Instituição: Universidade Federal de Santa Catarina Julgamento: 
À Italo Magri, meu avô, que não pôde ouvir o fim dessa história. 



\section{Agradecimentos}

Nomear as alianças afetivas que juntas teceram esse texto, para mim, é como um "ritual de coexistência" que explicita que os nossos "limites se confundem" e sempre são, na verdade, formas de "ser muitos" e de "existir com", como a linda imagem de uma "revoada de pássaros" invocada numa pequena nota de rodapé de Cafira Zoé (2019, p. 68-69).

As palavras grafadas nesta "pele de papel" (papel siki) são apenas um pedacinho de todo um mundo partilhado ao qual tive a alegria de viver junto. "Nossas palavras não acabam nunca", é o que sempre me diz Adriano Pukimapiwëteri, liderança do xapono ("casa-aldeia") Pukima Cachoeira. A ele e a toda sua família, minha mais sincera gratidão por receber-me, nestas últimas viagens, como aliado e, mais do que isso, como parte da família. Por todo o cuidado e o aprendizado, agradeço e muito, pois, como dizem por lá, "não foi pouco não" tudo o que vivi e aprendi ao redor do fogo, no meio do xapono, embrenhado no mato, trabalhando na roça, balançando e sonhando na rede, andando pra lá e pra cá na cidade, sentado na sala de aula e navegando rio acima e rio abaixo. A todos os Yanomami do Marauiá, meus tantos amigos, cunhados e parentes de pura afinidade potencial que sempre nos recebem com alegria e uma saudável desconfiança em suas casas, onde penduramos nossas redes, deixo aqui meu mais profundo agradecimento. Saibam que cada um e cada uma de vocês seguem vibrando nas entrelinhas desse texto e também em mim, com muito carinho, no interior da minha "morada do pensamento" (puhi; Lizot, 2004, p. 334).

Os caminhos que me conduziram até aqui foram abertos em 2016, quando conheci os Yanomami do Rio Marauiá (Amazonas, Brasil). Desde então, fiz quatro viagens para diferentes aldeias, ficando cerca de um mês em cada uma delas, e uma outra mais curta apenas para Santa Isabel do Rio Negro, como dizem, "para resolver problema" e "para fazer projeto". Em todas essas viagens nunca estive sozinho. Daniel Jabra, amigo do peito e duplo arquiteto-antropólogo como eu, sempre esteve junto, de modo quase indiscernível, a ponto de sermos chamados pelos Yanomami de ThiagoDaniel ou DanielThiago, mesmo quando separados, andando por aí, e até no telefone. Assim, imagine o leitor que nesse texto a primeira pessoa do singular não está sozinha, mas sempre junta e composta. Eu, 
aqui, somos nós. E ao Daniel, só tenho a agradecer pela partilha, pela paciência, pela parceria, pelo carinho e pelo cuidado.

Um agradecimento especial a Anne Ballester, quem mediou os nossos primeiros contatos com os Yanomami. Foi graças a seu apoio e sua confiança inicial que esse trabalho hoje existe. À ela, agradeço também pela ajuda com algumas traduções e pelas aulas à distância, valiosas para uma introdução à língua yanomami e importantes para nos manter em rede, especialmente agora com seu retorno à França e maior distância do Marauiá, onde morou por muitos anos e desenvolveu importantes projetos de formação na língua portuguesa e de formação política, apoiando fortemente a criação da Associação Kurikama Yanomami. Espero que, de diferentes maneiras, possamos dar continuidade aos trabalhos com os Yanomami com a mesma potência e seriedade.

Atualmente, como forma de continuar apoiando as escolas diferenciadas do Marauiá, organizamos o "Projeto Marauiá - Escola Yanomami", que dá apenas os primeiros passos e configura-se como um grupo de apoio aos projetos e demandas próprias dos Yanomami da região. Nesse projeto, estou aliado ao Daniel, a Tamara Miranda e a Thamirez Lutaif. Obrigado pela parceria. E como diz Adriano, "nossa luta é muito forte, nossa luta não vai acabar nunca" e, no que nos for possível, seguiremos "lutando junto". Agradeço também aos muitos colaboradores e colaboradoras, de distintas gerações e experiências, da recém formada Rede Pró-Yanomami e Ye'kwana, pelos aprendizados sobre os sentidos e potências do engajamento político e indigenista em tempos difíceis.

Meus sinceros agradecimentos a Pedro de Niemeyer Cesarino pela orientação sempre estimulante, atenta e cuidadosa. Agradeço também a Renato Sztutman e José Antonio Kelly Luciani pela leitura e pelos comentários valiosos na banca de qualificação. E pelo diálogo instigante e em muito iluminador estabelecido na banca de defesa, agradeço profundamente a José A. Kelly Luciani, Guilherme Wisnik e Beatriz Perrone-Moisés (além do Pedro Cesarino pela mediação), cujas falas e comentários seguem e seguirão ressoando em meu pensamento.

Agradeço a Karolin Obert, pela assessoria linguística e, mais do que isso, pela companhia vital, de perto e de longe; Helder Perri Ferreira, pelo apoio linguístico especializado e fundamental; Julia Thompson, pelo cuidado com as imagens que compõem esta dissertação; e Ismar Tirelli Neto, pelo cuidado com as palavras desse texto, mas também pelas oficinas 
de escrita, momentos e espaços vitais de aprendizado, debate, encontro e amizade.

Aos professores, funcionários e amigos da FFLCH-USP e do PPGAS, deixo aqui a minha gratidão a todos e todas que cruzaram meu caminho sempre com com muito a me ensinar, dentro e fora da universidade, em especial Pedro Cesarino, Renato Sztutman, Beatriz Perrone-Moisés, Morgane Avery, Erick Vidal, Lucas da Costa Maciel, Fabiano Azola, Brett Buckingham, Maria Carolina Fernandes, Luisa Suriani, Julia Ferezin e Paula Berbert.

Um agradecimento também aos muitos amigos e amigas, alunos e alunas, colegas, professores e professoras da Escola da Cidade pela escuta sempre atenta, pelo espaço tão generoso e pelo prazer de ensinar e de aprender. Ao Guilherme Paoliello e toda a equipe do escritório, agradeço o interesse constante, os estímulos e a paciência durante meus períodos de ausência, além da oportunidade que me é sempre tão cara de voltar os pés no chão para desenhar, construir e ver os espaços tomarem forma, corpo, espessura e densidade. À Marília Gallmeister, Cafira Zoé, Camila Mota e tantxs outrxs artistas do Teat(r)o Oficina e da Universidade Antropófaga, agradeço e celebro as partilhas, as confluências e as insurreições vitais, "importantes e miúdas", passadas e por vir.

Aos amigos e amigas, Pedro Correia, Vitor Pissaia, Bruno Buccalon, Bruna Keese, Rodrigo Messina, Wellington Cançado, Renata Marquez, Isabella Beneduci, Renee Nader e João Salaviza, obrigado pelos diálogos, pelas trocas e pelos encontros que provocaram, instigaram e alegraram esse caminho. Agradeço também Ederson Lopes, pelo equilíbrio e pelas pausas para respirar, cada vez mais necessárias; Maiara Moraes, pelos sons e pelos pios que fez nascer em mim, colorindo e musicando os caminhos; e Heloiza Abdalla, por ensinar-me a escutar a minha própria fala e também o meu próprio texto. À minha família, enfim, agradeço por fazerem com que tudo isso exista. Faltam as palavras para agradecer tamanho cuidado, estímulo, respeito, paciência e amor. À todos e todas que aqui invoco e celebro, mais uma vez, obrigado pela afinidade vital. 
O presente trabalho foi realizado com apoio da Coordenação de Aperfeiçoamento de Pessoal de Nível Superior - Brasil (CAPES) - Código de Financiamento 001.

This study was financed in part by the Coordenação de Aperfeiçoamento de Pessoal de Nível Superior - Brasil (CAPES) - Finance Code 001. 


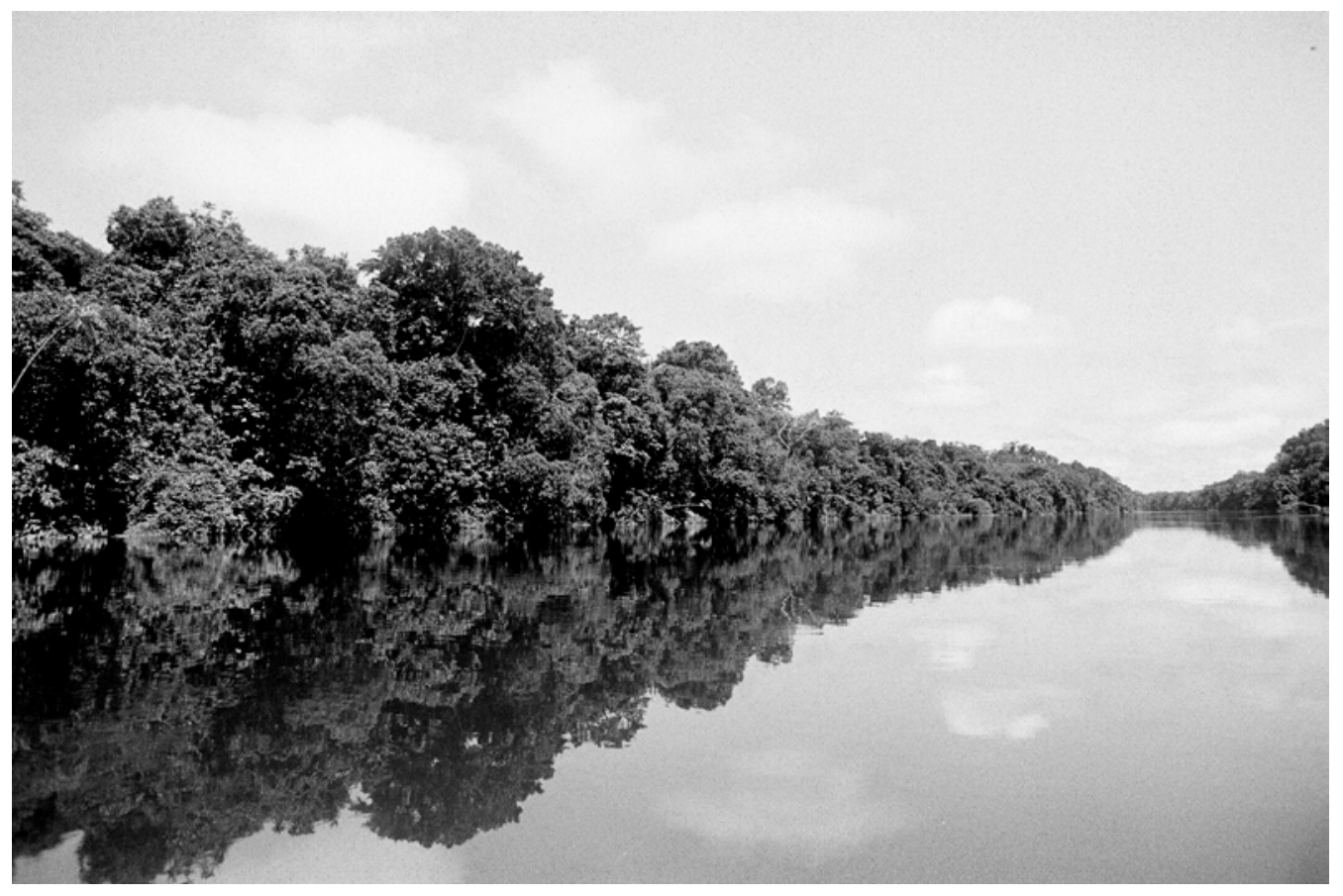

Fig. 01. "Subir um rio de afetos" (Jabra, 2020), pela primeira vez, em uma manhã de 2016, no Baixo Rio Marauiá. Fotografia de Daniel Jabra. 



\title{
Resumo
}

Esta dissertação é um estudo etnográfico sobre a arquitetura yanomami. A pesquisa parte da relação etnográfica construída com interlocutores do Rio Marauiá (Amazonas, Brasil) para descrever e pensar com as concepções em torno das formas de construir e habitar yanomami: os acampamentos temporários na floresta, as casas-aldeia nas clareiras domésticas, as casas-montanha habitadas pelos espíritos e também as casas de espíritos construídas no peito dos pajés durante as iniciações xamânicas. Dentre os problemas e conceitos que permeiam esse trabalho, destacam-se os movimentos de agregação e de desagregação dos grupos e das moradas; os regimes de transformação das casas e dos corpos; os sentidos míticos e xamânicos em torno das categorias do perecível e do imperecível; e a ubiquidade e a recursividade das casas de espíritos xamânicos.

Palavras-chave: Yanomami. Arquitetura. Casa. Xamanismo.

\begin{abstract}
This dissertation is an ethnographic study of Yanomami architecture. The research starts from the ethnographic relationship built with interlocutors from the Marauiá River (Amazonas, Brazil) to describe and think with the conceptions around the yanomami ways of building and dwelling: the temporary camps in the forest, the village-houses in the domestic clearings, the mountain-houses inhabited by the spirits and also the spirit houses built in the shamans' chest during shamanic initiations. Among the problems and concepts that permeate this work, stands out the movements of aggregation and disaggregation of groups and addresses; the transformation regimes of houses and bodies; the mythical and shamanic senses around the categories of the perishable and the imperishable; and the ubiquity and recursion of shamanic spirit houses.
\end{abstract}

Keywords: Yanomami. Architecture. House. Shamanism. 



\section{Sumário}

Apresentação

I

Sangue da Lua

33

Terra-floresta

61

II

Tapiri

81

Casa-aldeia

113

III

Viver junto

175

Casa-montanha

205

Assim é

249

Referências

253 



\section{Apresentação}

Eu estava me pensando e eu sou uma pequena dúvida.

Jonas Konapimateri Yanomami

(Miranda, 2020, p. 26)

Esta dissertação é um estudo etnográfico sobre a arquitetura yanomami. Por arquitetura, refiro-me às concepções em torno das casas e dos espaços construídos e habitados pelos Yanomami: os acampamentos temporários na floresta, as casas-aldeia nas clareiras domésticas, as casas-montanha habitadas pelos espíritos e também as casas de espíritos construídas no peito dos pajés durante as iniciações xamânicas. Em outros termos, assim como pensado conjuntamente com um interlocutor do Rio Marauiá, o conceito de arquitetura poderia ser traduzido (e com isso inventado) na língua yanomami por yãatamotima, com o sentido de (se retraduzido ao português) "como fazer as casas" ou "o jeito de pendurar redes". A pergunta de fundo que guia esse trabalho, então, é a seguinte: como os yanomami fazem suas casas e penduram as suas redes? Por esse caminho, esta etnografia desdobra-se como um experimento de diálogo com o pensamento yanomami e com os modos de habitar a terrafloresta (urihi) através do encontro de dois regimes intelectuais, poéticos e arquitetônicos.

Esse diálogo foi tecido por uma relação de aliança com interlocutores yanomami do Rio Marauiá (Amazonas, Brasil), onde esta etnografia se situa. O trabalho, entretanto, não se limita exclusivamente a esse contexto etnográfico e traça também conexões pontuais com outras regiões do território yanomami, assim como com outros autores e autoras. Tendo em vista as proximidades mas também as diferenças entre os grupos, a etnografia dialoga com os modos de habitar yanomami, de um ponto de vista mais amplo, através das diversas e importantes referências constantes na bibliografia yanomami. Estas, no entanto, são colocadas em diálogo com as reflexões que partiram da minha própria experiência no Marauiá. Apesar das conexões, este não é um trabalho comparativo sistemático da arquitetura dos diferentes subgrupos ou das diferentes regiões, pois certamente me faltam conhecimento, experiência e dados 
para tal empreitada. O texto resultante é o produto das relações e dos aprendizados que tive até então e, da mesma forma, seus limites e lacunas derivam também da curta duração do meu trabalho de campo (cerca de cinco meses distribuídos em cinco viagens entre julho de 2016 e fevereiro de 2020) e por meus muitos limites de compreensão e aprendizado da língua yanomami.

Dentre os estudos yanomami, essa etnografia se soma aos trabalhos de Bruce Albert \& William Milliken (1997), Graziano Gasparini e Luise Margolies (2004) e, especialmente, de Alejandro Reig (2013) que, de diferentes maneiras, se põem a pensar sobre as noções de espaço e as formas de construir e habitar dos Yanomami. Do ponto de vista teórico, esse trabalho estabelece um diálogo com a coletânea Habitações Indígenas, organizada por Sylvia Caiuby Novaes (1983), que reflete sobre as concepções e as formas de produção do espaço habitado em distintos povos indígenas no Brasil e, também, com os estudos associados ao campo da antropologia da arquitetura, conforme proposto e estimulado por Janet Carsten e Stephen Hugh-Jones em About the house: Lévi-Strauss and beyond (1995). O ponto central de tais estudos, que poderiam ser estendidos também a outras referências importantes (Hugh-Jones, C., 1979; Blier, 1987; Ingold, 2000; Low; Lawrence-Zúñiga, 2003; Fox, 2006; Marchand, 2009), é voltar a atenção para os potenciais significados da arquitetura, muitas vezes negligenciados pela análise antropológica, e pensar os espaços construídos e as casas, especialmente, de forma holística, através da relação entre as construções, as pessoas e as ideias que engendram aqueles espaços.

As casas, como sugerem Carsten e Hugh-Jones, tratando de contextos indígenas das terras baixas da América do Sul e do Sudeste Asiático, são "lugares nos quais o ir e vir da vida revela-se e é construído, modificado, movido ou abandonado de acordo com as mutáveis circunstâncias dos seus habitantes, e essas características dinâmicas e processuais das casas são encapsuladas na palavra 'habitação' (dwelling)" (1995, p. 1, tradução nossa, como todas as seguintes). Nesse sentido, habitar (to dwell), como propõe Giorgio Agambem a partir da releitura da análise linguística de Émile Benveniste, "significa criar, conservar e intensificar hábitos e costumes, isto é, modos de ser" e, assim, é como se significasse "ter certo modo de ser", de modo que "a habitação (dwelling) se torna uma categoria ontológica" (2019, p. 7). É na casa ou na habitação, 
portanto, que se "transforma o ser em um ter: em habilidades, técnicas, hábitos e costumes", transformando o lugar em seu "lugar de 'habitar', onde construir, conhecer e exercitar intensamente seus 'hábitos"' (2019, p. 7).

Seguindo ainda a proposição de Tim Ingold (2000), esse lugar de habitar, para além da habitação em si, deve ser pensado de uma certa perspectiva do habitar (dwelling perspective) que conceba a produção dos espaços como frutos de uma relação intrínseca entre humanos e não-humanos, assim como entre o habitar e o construir, e contrária à dicotomia entre sociedade e natureza. Tal perspectiva, contudo, não deve ser pensada de forma supostamente harmônica mas, pelo contrário, no âmbito de uma política do habitar (politics of dwelling; Ingold, 2005) que agencia múltiplos e contínuos processos de agregação e desagregação, alianças e conflitos, habitação e mudança, construção e destruição, estabilização e movimento. É a partir dessas perspectivas, então, que desenvolvo esse estudo etnográfico das formas e concepções em torno da casa e do habitar entre os Yanomami e, mais especificamente, do "jeito yanomami de pendurar redes".

A tradução do conceito de arquitetura que originou a ideia de "o jeito de pendurar redes", título e fio condutor deste trabalho, teve origem em uma longa assembleia que reuniu lideranças, professores, mulheres e pajés de todo Alto Rio Marauiá no xapono Pukima Beira em janeiro de 2019. O objetivo daquele encontro era de elaborarmos coletivamente o projeto arquitetônico das escolas nas aldeias, de acordo com as reivindicações dos Yanomami da região. No primeiro dia, Daniel Jabra e eu, enquanto arquitetos e aliados nesse processo, achamos por bem introduzir a disciplina e contamos um pouco sobre esse exótico ofício. A ideia do desenho como algo que antecede a construção, por exemplo, causou reações adversas e irônicas: "Mas os brancos precisam de desenho para fazerem as casas deles? Eu não!". E alguém complementou, orgulhoso: "Eu também não!". Concordamos, no entanto, que o desenho é um tipo de documento e os brancos realmente precisavam disso, afinal "eles gostam de papel".

Em uma das tardes da assembleia, já um pouco cansado, sugeri a um hábil tradutor yanomami, Maurício Iximawëteri, que pensasse na reinvenção da palavra "arquitetura". Passado alguns minutos, o estimado tradutor virou para o meu lado da carteira e disse, de modo certeiro como quem resolve uma charada: "yãatamotima". "Yãatamotima quer dizer como fazer as casas", explicou-me Maurício, num breve intervalo 
da complicada tradução simultânea que ele fazia, sentado entre nós, ao pé do nosso ouvido. Longe da aldeia e dessa vez retomando o esforço tradutório em seu sentido inverso, penso que o conceito de yãatamotima poderia ser retraduzido por "o jeito de pendurar redes". A retradução, como veremos a seguir, reinventa com alguma liberdade e criatividade poética a análise mais literal dos morfemas que compõem o termo criado por Maurício. Em todo caso, procura, assim, desvelar as implicações de ordem conceitual àquilo que nós, os napë (os "brancos"), chamamos de arquitetura ou, nesse caso, de arquitetura yanomami.

A estrutura morfológica da palavra yãatamotima (yãa-ta-motima / morar-fazer-INTR-NMLZ) reflete a habilidade e a criatividade do tradutor, mas também a liberdade e a flexibilidade que a língua yanomami tem para criar novas palavras. Esta, em particular, conforme análise em colaboração com o linguista Helder Perri Ferreira (informação pessoal), tem sua etimologia composta pela raiz verbal yã-, um verbo intransitivo, do tipo posicional, com o sentido de "estar pendurado por uma corda", cujo exemplo prototípico seria a rede. Como um derivado deste, o verbo transitivo yãai significa "pendurar algo por uma corda" e, da mesma forma prototípica, mas não exclusiva, "pendurar a rede". Já o verbo de estado e intransitivo yãa, que compõe a raiz da tradução de yãatamotima, é uma segunda derivação a partir do verbo transitivo (yãai), com o sentido de "ter a rede atada em um lugar", como também nota Jacques Lizot (2004, p. 485), mas também de "morar", "residir", "viver" e "habitar". Nesse caso, então, o verbo de estado yãa forma uma expressão com o verbo transitivo tai̇ ("fazer", "construir", "realizar", da raiz verbal ta-), yãa taí, com o sentido aproximado de "fazer morada para viver" - um tipo de construção que aparece com outros verbos de estado com sentido similar, como ohi tai, "procurar/trabalhar pela comida" e literalmente "fazer sentir fome. Seguindo com a análise, o morfema intransitivizador -mo-, geralmente associado a verbos que implicam em repetição ou hábito (Lizot, 2004, p. 232-233), torna a expressão reflexiva, de modo que yãa tamou passa a significar "fazer morada para si mesmo", assim como pode ser observado em outros casos dessa expressão verbal, como ohi tamou, "procurar/trabalhar por comida para si mesmo". Ao fim, o nominalizador -tima torna a expressão verbal reflexiva em um nome. Yãatamotima, assim, poderia ser literalmente traduzida como "o fazer morada para si mesmo". Ao que parece, yãatamotima é um neologismo, mas como aponta Ferreira 
(informação pessoal), cuja formação segue um padrão recorrente na língua, assim como a tradução de "economia" que este certa vez notou na língua Yanomam: ohith amotima (ohi-tha-mo-tima / fome-fazer-INTR-NMLZ).

Minha retradução por "o jeito de pendurar redes", entretanto, combina com alguma liberdade a análise morfológica ("o fazer morada para si mesmo") à explicação do próprio tradutor do termo yãatamotima: "como fazer as casas". Segundo Maurício, yãa- indica a "casa", de modo que se compreendermos o verbo de estado "morar" nominalizado em uma forma particular, temos aí a "casa" - síntese dessa arquitetura de morar yanomami. Assim como a raiz verbal përi-, que significar "morar" e tem sua etimologia relacionada ao sentido de "deitar na rede" (voltaremos a ela no capítulo "Tapiri”), conjugando a lógica da tradução de Maurício e o campo semântico da raiz verbal yã-, poderíamos pensar a ação de "pendurar a rede" como o ato de "habitar" e, com isso, compreender a "casa" como "o lugar onde penduro a rede". De forma análoga, por exemplo, o termo hato nahi pode significar tanto a "casa" quanto o "poste onde se ata a rede". Assim, "pendurar a rede" corresponderia tanto à raiz quanto ao elemento mínimo, no sentido de uma noção fundamental, da inventiva tradução de arquitetura. O "como fazer" da explicação de Maurício, por sua vez, me parece relacionar-se com a expressão formada com o verbo transitivo taì ("fazer") e também com o nominalizador (-tima) enquanto algo que possui uma forma própria de ser feita, "o jeito", e que se apresenta, portanto, como um hábito, tal como aponta o morfema -mo-. "O jeito de pendurar redes".

Maurício, não por acaso, é uma pessoa dedicada à manutenção, documentação e conhecimento da língua e do pensamento yanomami, além de ser Agente Indígena de Saúde (AIS, como se diz), o que lhe permite, através do conhecimento adquirido sobre e com o nosso mundo, realizar traduções provocantes como essa de arquitetura. Provocante, quero dizer, no sentido de sua capacidade de "fazer com que os conceitos alheios deformem e subvertam o dispositivo conceitual do tradutor [...] e assim transformar a língua de destino" (Viveiros de Castro, 2015, p. 87). Arquitetura era, realmente, um problema novo por ali e sua tradução e invenção por yãatamotima, para além de transformar a língua de destino (yanomami) acaba por subverter também a língua de origem (português). De forma análoga, a reflexão que construo em torno da retradução "o jeito de pendurar redes" procura, no limite, tensionar as nossas próprias noções 

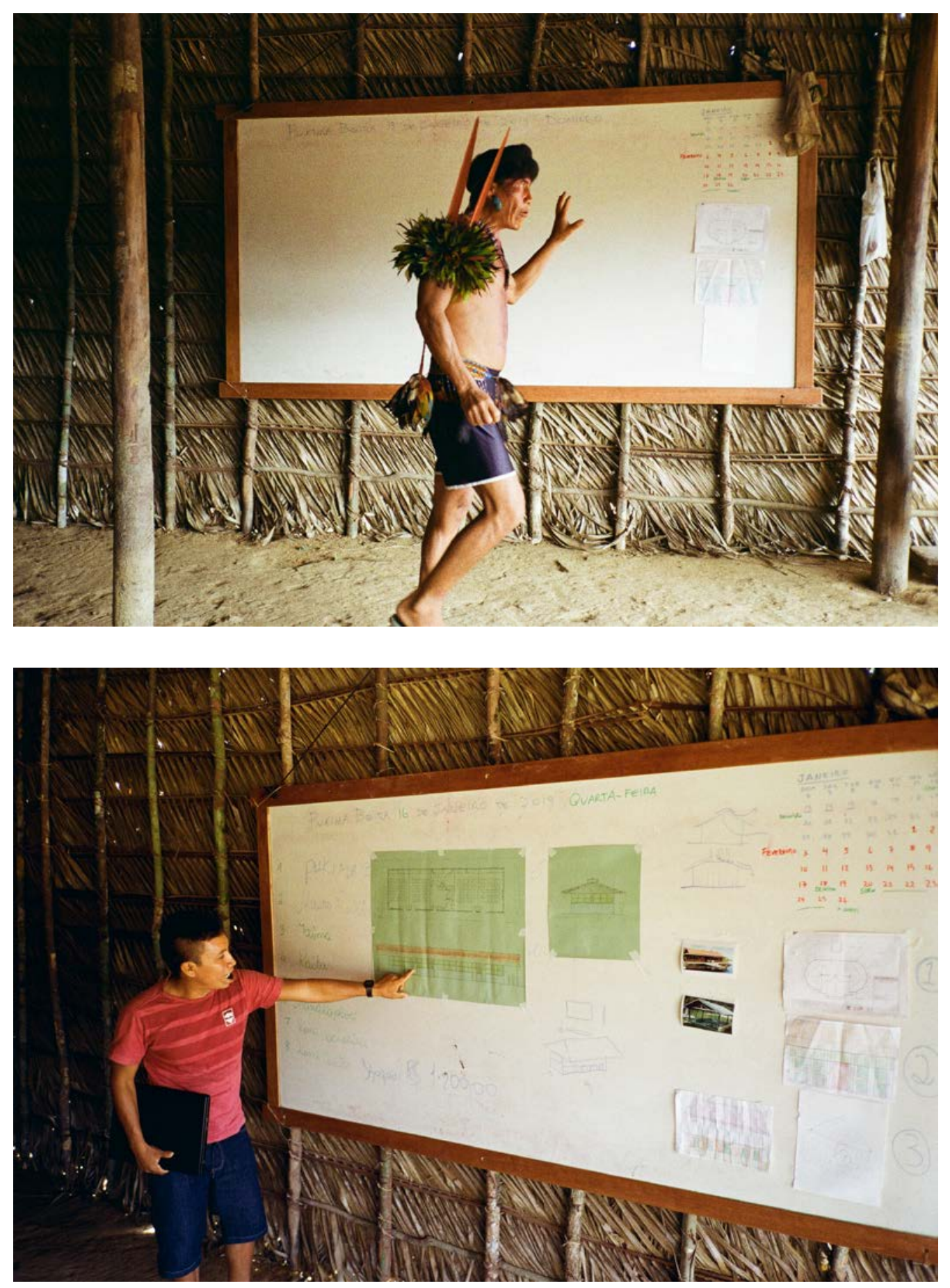

Fig. 02/03. Acima, Mario, pajé do Pukima Beira, durante assembleia no mesmo xapono, em 2019, para discutir e formular o projeto das escolas reivindicado pelos Yanomami do Alto Rio Marauiá. Abaixo, Francisco, agente indígena de saúde e pajé do Pukima Cachoeira, traduz e explica aos demais presentes na assembleia os desenhos técnicos que formulamos. 
de arquitetura, agora em contato com essa potencial arquitetura yanomami.

Esse procedimento tradutório, todavia, não pretende transpor problemas próprios de nosso pensamento para o dos outros, nem perseguir critérios filosóficos ocidentais e tampouco tratar dos modos de habitar yanomami a partir de nossas próprias categorias como forma de validar as práticas alheias. Como Neide Pukimapiwëteri (filha de Adriano $e$ jovem professora yanomami) me disse certa vez em uma elegante síntese: "Nosso pensamento. Outro pensamento". Por outros caminhos, a arquitetura é entendida aqui como "perspectiva" (Gow, 1996, p. 221), como ponto de vista e como ponto de partida explicitamente situado em nosso pensamento, mas que aponta para outro puhi, isto é, para outra "morada do pensamento" (Lizot, 2004, p. 334).

Dessa forma, o objetivo do exercício tradutório que guia esse trabalho é propor uma experiência de reflexão em que os problemas internos do pensamento yanomami sejam colocados em diálogo com os nossos (Cesarino, 2011, p. 19). Esse diálogo se dá através de uma reinvenção de nossa imaginação conceitual a partir dos termos da imaginação conceitual yanomami (ela própria hábil na tradução entre mundos), tal como traduzida por mim. Afinal, como diria Eduardo Viveiros de Castro, não temos outros termos de onde partir, "mas, e aqui está o ponto, isso deve ser feito de um modo capaz (se tudo 'der certo') de forçar nossa imaginação, e seus termos, a emitir significações completamente outras e inauditas" (2002, p. 15).

"Palavras existem em complexas relações umas com as outras", mas para que essas tenham efeito, como sugere Marilyn Strathern, é necessário aprender "como fazer relações" e "como fazer palavras" (2005, p. xii-xiii), de modo que as complexidades de tais inter-relações nasçam desse acordo. Assim, para que as relações de diálogo, aliança, invenção e tradução sejam devidamente feitas, mantidas e manejadas, atento-me especialmente para os jeitos de fazer, os "jeitos de pendurar redes" na terra-floresta, do tapiri à casa-aldeia, da casa-aldeia à casa montanha. Este é o começo da história. E no caminho que daqui se desdobra, a pergunta: como os Yanomami penduram as suas redes?

Como desdobramentos dessa questão, a arquitetura do texto dessa dissertação consiste em um conjunto de capítulos divididos em três partes, somadas a esta apresentação e à um epílogo ao final ("Assim é"), que procuram pensar com as complexidades e as multiplicidades 
implícitas à ideia de "o jeito de pendurar redes". Na parte I, de cunho introdutório, o capítulo "Sangue da Lua" organiza uma síntese do processo histórico de ocupação territorial do Rio Marauiá - onde este trabalho se situa e de lá parte - a partir de distintos referenciais. O marco inicial dessa história, bem como desse capítulo, foi a narrativa mítica sobre a origem dos Yanomami a partir do sangue da Lua (Periporiwë), contado por Adriano Pukimapiwëteri. Ao longo da descrição dos muitos movimentos, conflitos, cisões e fundações de novos xapono ("grupo local", "casa-aldeia") se configura, então, o campo sobre e com o qual esse trabalho foi desenvolvido. No capítulo seguinte, desdobro os múltiplos sentidos do conceito yanomami de urihi ("Terra-floresta", título do mesmo), promovendo um encontro do pensamento de Davi Kopenawa (e Bruce Albert) com o de Adriano. Nesse mesmo capítulo, apresento também outros conceitos base que permeiam o trabalho, como a noção de "imagem" (no uhutipi) e de "ser-imagem" ou "espírito" (hekura). Na parte II, em "Tapiri", discorro sobre as caminhadas e os acampamentos temporários (yãno) no mato, em diferentes contextos, apresentando as formas e também as variações de suas soluções construtivas. Na sequência, no capítulo "Casa-aldeia" penso com os distintos sentidos e perspectivas da ideia e da construção do xapono. Variando entre formas mais ou menos temporárias, o movimento de agregação e desagregação - problema que permeia a etnografia como um todo - configura-se em diferentes formas de habitar o xapono que, em suma, transformam-se continuamente. Na parte III, em "Viver junto", reflito sobre a dimensão da palavra na construção e na manutenção da vida coletiva (yaiprou, "viver junto") do xapono a partir dos diálogos kãwãamou. E no capítulo final "Casa-montanha" penso as distintas configurações do habitar através da oposição entre o perecível e o imperecível e apresento, assim, as ideias e as narrativas em torno da construção da "casa de espíritos" (hekura pë yahi pì) no peito dos pajés, processo que decorre de forma ubíqua, recursiva e simultânea à iniciação xamânica (taamayõu).

De diferentes maneiras, como se irá notar, em todas as partes dessa etnografia procuro articular as especulações míticas e xamânicas com elementos concretos da arquitetura yanomami com a intenção, portanto, de abrir um caminho (parcial e incompleto, evidentemente) rumo "às possibilidades inerentes à sua estrutura, suas virtualidades latentes" (Lévi-Strauss, 2013, p. 199). Assim, seguindo a lógica do pensamento 
mítico-xamânico, sugiro que para aprender sobre as formas yanomami de habitar e construir é fundamental deter-se também sobre seus processos de formação e montagens de mundo. Como propõe Lévi-Strauss, num contexto diferente, mas com o objetivo análogo de traçar possíveis conexões entre arquitetura e cosmologia: "para entender o que esse tipo de estrutura [arquitetônica]", ou esse modo de habitar, pode significar para os próprios yanomami, "devemos deixar que seus textos antigos [entendase, de minha parte, narrativas míticas e xamânicas] falem" (2001, p. 15).

Ailton Krenak, à sua maneira, compartilha de ideia análoga e que, fundamentalmente, inspira essa etnografia. Para ele uma das diferenças fundamentais entre as narrativas antigas ameríndias e as ocidentais é o fato de que as primeiras não são datadas, ao contrário, sua marca temporal "é quando foi criado o fogo, é quando foi criada a Lua, quando nasceram as estrelas, quando nasceram as montanhas, quando nasceram os rios" (Krenak, 1994, p. 202). E isso não quer dizer que nada existia antes do fogo ou da Lua: "Antes, antes, já existia uma memória puxando o sentido das coisas, relacionando o sentido dessa fundação do mundo com a vida, com o comportamento nosso, com aquilo que pode ser entendido como o jeito de viver" (Krenak, 1994, p. 202). Seguindo o pensamento de Krenak, são as histórias dos antigos que puxam "o sentido das coisas", de modo que cada vez que são recontadas estas se atualizam e conectam a construção do mundo com o jeito de viver junto na terra-floresta, ambos em constante transformação. E, enfim, o que me parece essencial para essa experiência de pensamento: "Esse jeito de viver que informa a nossa arquitetura, nossa medicina, a nossa arte, as nossas músicas, nossos cantos" (Krenak, 1994, 202). Assim, poderíamos pensar que são as narrativas antigas que informam o jeito de viver e, simultaneamente, são estas que que sustentam "o jeito de pendurar redes".

Ao fim, complementando esta apresentação ao texto, valem algumas breves notas sobre a língua e os subgrupos yanomami, bem como sobre as traduções e as imagens que aqui apresento. No texto, como já deve ter sido notado, me refiro aos Yanomami, enquanto povo, de duas maneiras. A primeira é Yanomami, que é o nome pelo qual todo o conjunto de subgrupos linguísticos e culturais é conhecido aqui e internacionalmente e, além disso, como estes se autodeterminam, especialmente no campo da política interétnica, como um único povo. Essa forma é mobilizada nos casos em que me refiro aos Yanomami de uma perspectiva mais geral e consciente 
dos limites desse tipo de formulação, dadas as muitas diferenças entre os grupos e mesmo no interior de cada um destes. A segunda é Yanomami, com " $\mathrm{i}$ ", que corresponde a um dentre os seis subgrupos linguísticos (com dezesseis dialetos falados no território brasileiro, todos relacionados à família linguística isolada yanomami [cf. Ferreira; Senra; Machado, 2019]) e que é a língua falada no Marauiá (dialeto Xamatari ou Yanomami do Oeste), onde os grupos que lá habitam também se reconhecem assim, isto é, como o subgrupo Yanomami, diferenciando-se dos demais subgrupos linguísticos e culturais (Yanomam, Ninam, Sanöma, Ỹaroamë, Ninam e Yãnoma). No Brasil, os Yanomami (também conhecidos por Yanomami ocidentais) ocupam o lado oeste da Terra Indígena Yanomami (homologada em 1992 e compartilhada ao norte com o povo Ye'kwana), tanto no extremo oeste, na região do estado do Amazonas, quanto nas terras altas da Serra Parima, na fronteiras entre Venezuela e Brasil, no estado de Roraima. E no todo da população estimado entre 36.000 pessoas, nos dois países, esse subgrupo corresponde a cerca de $60 \%$ da população, sendo que a maioria está no lado venezuelano do território.

O etnônimo "Yanomami", entretanto, é aqui mobilizado ao me referir especificamente ao povo (ou especificamente à língua) Yanomami do Rio Marauiá, ponto de partida da maioria das reflexões que compõem esta etnografia, de modo a especificar e situar o texto que aqui apresento. Nos casos em que me refiro a grupos yanomami de outras regiões ou a grupos yanomami de outros subgrupos linguísticos, a partir da extensa bibliografia yanomami, estes serão devidamente indicados e, quando for o caso, apresentarei a tradução alternativa do termo em questão. Um caso que merece destaque de antemão são as referências às palavras e ao pensamento do pajé Davi Kopenawa em colaboração com o tradutorantropólogo Bruce Albert, em especial, a partir d'A queda do céu (2015). Kopenawa é falante da língua yanomam que, dentre as seis línguas da família linguística, é aquele que apresenta maior proximidade ao yanomami. Além da proximidade linguística, há também relações estreitas no que diz respeito ao pensamento conceitual, xamânico e metafísico entre os dois grupos. Pontualmente, as diferenças marcantes serão apontadas e, em outros momentos, as relações de proximidade serão assim expostas, seja como forma de complementar ou de corroborar o meu argumento.

Diferente dos Yanomami e, principalmente, dos professores e professoras, lideranças, agentes de saúde, jovens que frequentam a escola e 


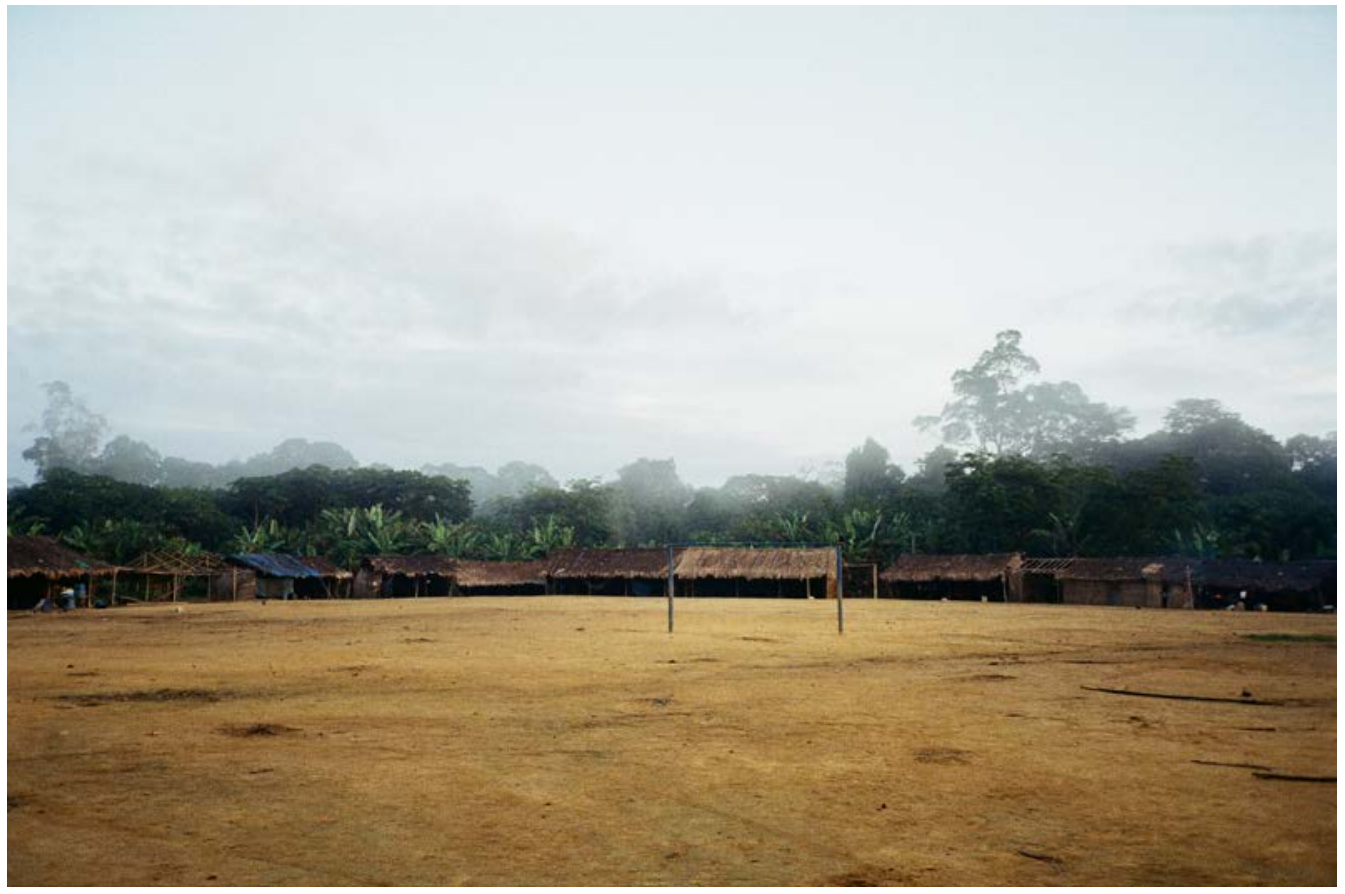

Fig. 04. Amanhecer no xapono Pukima Beira. Fotografia do autor, como todas em que a autoria não está indicada (2019). 
todos aqueles com maiores contatos com a cidade ou com possibilidades de estudo da língua portuguesa (os homens em maior proporção), não tenho ainda um domínio suficientemente razoável da língua yanomami para sustentar uma conversa cotidiana de modo fluído. Nossa relação, então, foi construída em torno da língua portuguesa e do paulatino aprendizado da língua yanomami, em paralelo ao constante esforço tradutório de ambas as partes. Os Yanomami, assim como os povos indígenas no geral, como se sabe, possuem um declarado interesse por línguas estrangeiras e são habilidosos tradutores. Logo, para aprender com as traduções feitas pelos indígenas, como sugere Beatriz Perrone-Moisés (2015), há de se atentar seriamente ao "português dos índios" e aos potenciais e desejosos ajustes de nosso vocabulário analítico-descritivo quando do encontro com estas outras traduções.

As traduções das poucas narrativas gravadas e que apresento de forma fragmentada nessa etnografia (especificamente no capítulo "Casamontanha") foram feitas a partir de dois relatos de Cândido, pai de Adriano, que é um reconhecido pajé e foi um grande guerreiro e o antigo përiomi do Pukima Cachoeira. A ele agradeço imensamente pela disposição, paciência e confiança, assim como pelo conhecimento transmitido e pelos atos de cuidado, mediados por seus espíritos auxiliares. Com a sua gentileza em gravarmos os relatos, pude posteriormente traduzi-los em conjunto com outros interlocutores e tradutores yanomami do Pukima Cachoeira: o primeiro, registrado em 2018 com Francisco, jovem pajé e Agente Indígena de Saúde (AIS), e o segundo, de 2019, com Mauro, professor na escola diferenciada. Aos dois, minha gratidão pela recepção sempre terna e pelos incontáveis ensinamentos. Nas transcrições e traduções diretas realizadas com interlocutores yanomami, ouvíamos os áudios, pausando quando necessário, dependendo do estilo de cada tradutor e da dificuldade de cada fala, sempre até o ponto em que sua capacidade mnemônica permitia, e eu tomava nota. Esse tempo variava de alguns segundos nas narrativas traduzidas mais minuciosamente e nas transcrições mais dificultosas - até alguns minutos - no caso das traduções livres e diretas de frases ou trechos inteiros dos relatos. Ao longo do trabalho estas serão indicadas, através de seus respectivos tradutores, no capítulo em questão.

Os Yanomami têm uma memória excepcional e conseguem fazer essas extensas traduções livres e diretas, nos dois sentidos (portuguêsyanomami e yanomami-português), com muita qualidade, inclusive 
de modo simultâneo ou após longas falas, como em assembleias ou reuniões interétnicas. Essa capacidade mnemônica é fruto da tradição de transmissão de conhecimento oral, através da longa reprodução de histórias antigas, narrativas míticas, infindáveis cantos associados aos pajés e espíritos hekura, um vasto repertório de cantos entoados durante os as festas funerárias reahu, além de histórias do contato com os brancos e suas formas de fazer política, com os serviços de saúde e de educação. Isso ficou evidente, sobretudo, nas longas horas que passei escutando e aprendendo com Adriano, enquanto ele atravessava os diversos gêneros dessas narrativas orais, às vezes numa só história. Foi especialmente com ele, então, que entendi como o modo propriamente yanomami de narrar uma história pode ser transposto e reinventado na língua portuguesa, de uma maneira excepcional, incluindo as citações diretas, o paralelismo, as interjeições, o ritmo e os gestos. Mais do que isso, com ele senti que estava sendo sistematicamente ensinado sobre o pensamento yanomami, no seu devido tempo e nos devidos espaços. E foi assim que aprendi um pouco sobre esse modo de pensar e de falar.

Nossos diálogos, no entanto, não teriam sido possíveis se mediados por um gravador de som, já que decorriam de situações cotidianas em momentos e lugares diversos: na beira do rio, no meio do mato, na soleira da casa ou ao redor do fogo, por exemplo. Com Adriano, portanto, aprendi e exercitei um pouco desse modo de apreensão, memorização e reprodução, só que através da escrita, replicando com citações diretas as falas e vozes de cada pessoa, do narrador ou de alguém citado, como nas práticas e nas artes verbais ameríndias. Às vezes o intervalo entre uma dada conversa e o momento em que conseguia tomar nota em meu caderno chegava a passar de um dia e, sendo assim, os relatos que aqui apresento nem sempre embasam-se em uma precisão absoluta, mas sim em uma criatividade atenta e responsável. Essas conversas com Adriano correspondem a grande parte das fontes que estruturam minha argumentação e, mesmo que não citadas na íntegra, foi com esses conhecimentos, transmitidos dessa maneira, que construí esse texto, reorganizando-os e complementando-os com outras fontes. Assim, tento transformar e transportar para a escrita, num contexto acadêmico, algo desse estilo de retórica, de pensamento e de diálogo. Penso esse texto, então, como um experimento de escrita ou, como instiga Donna Haraway, como uma pequena história capaz de sustentar "presentes espessos" sobre 
um mundo de "detalhes minuciosos de como viver e morrer juntxs" e sobre um modo "de viver densamente uns com os outrxs" (2020, p. 0910), mundo esse o qual tive a alegria de partilhar.

Por último, sobre as fotografias que apresento, de minha autoria ou de autoria de Daniel Jabra, ressalto que estas partem de acordos pragmáticos com os Yanomami sobre a possibilidade de captura e reprodução, em especial, aquelas em que corpos e rostos de pessoas são visíveis e reconhecíveis. Atualmente os Yanomami lidam com a produção de imagens sobretudo pela função política de sua circulação e, em outros casos, pela possibilidade de controle sobre sua destruição após a morte da pessoa fotografada. Isso, pois, quando essas não são devidamente destruídas junto com o corpo e os pertences da pessoa durante os procedimentos funerários, as imagens se constituem como marcas que podem trazer à tona a memória e a saudade das pessoas que deixaram essa terra rumo à aldeia dos mortos, causando sofrimento e dor entre os familiares, além de constituir um perigo sociocósmico que só pode ser manejado pelos pajés. Já nos casos em que a função política e pragmática é ressaltada, esses costumam partir de decisões individuais ou coletivas e, com isso, autorizando e assumindo os riscos do registro e da circulação. Como diz Adriano, "os brancos só acreditam nas coisas quando eles veem as suas imagens" e, por isso, para que essas gerem efeitos sobre os nãoyanomami, a produção e circulação das imagens são assim debatidas, negociadas e, eventualmente, autorizadas. Assim, as fotografias com pessoas identificáveis que apresento derivam de acordos pragmáticos específicos, seguindo as orientações e as restrições dos Yanomami, cuidado esse que deve à uma questão ética e ao meu mais profundo respeito a todos amigos e interlocutores do Marauiá. 


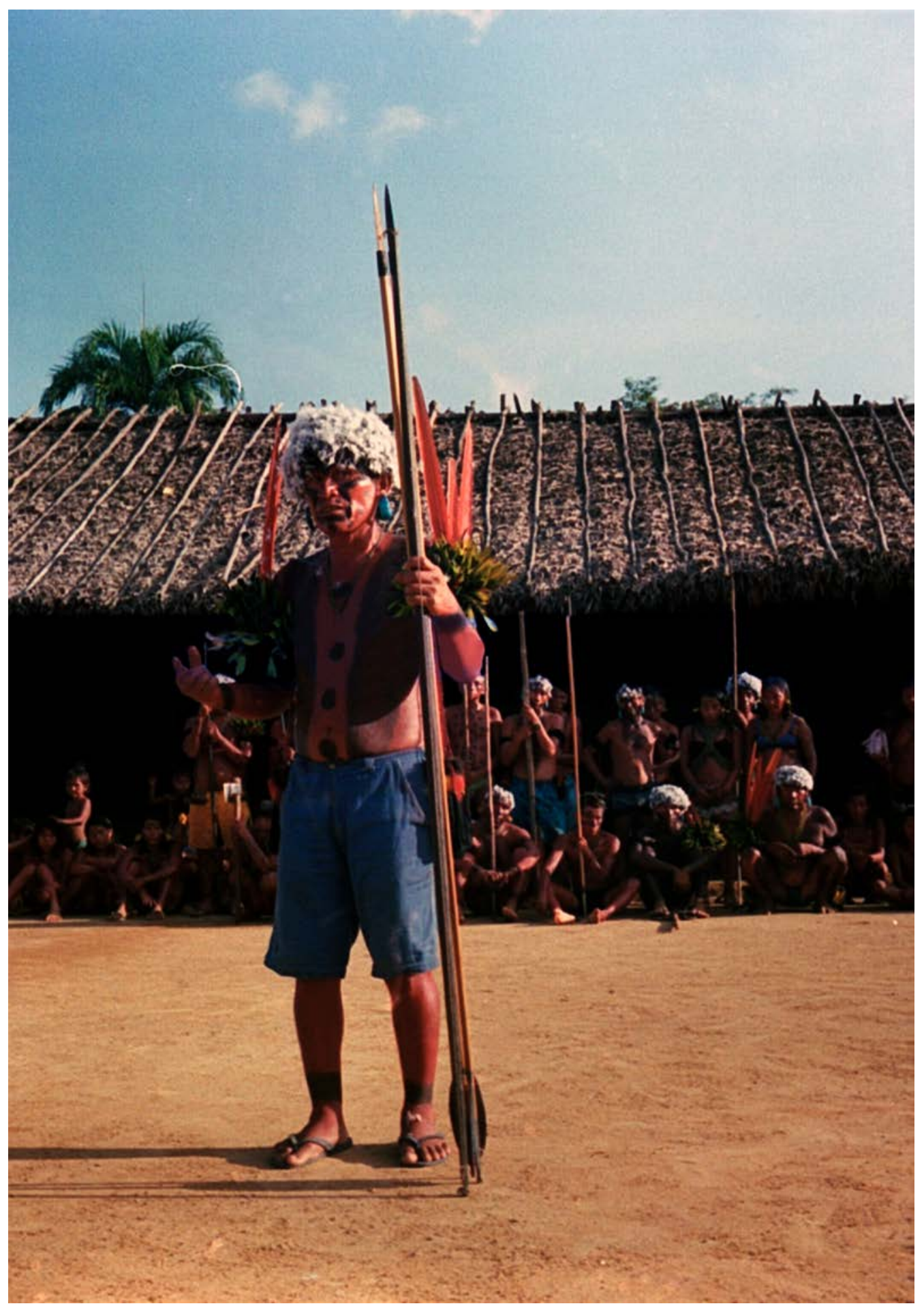

Fig. 05. O përiomi Adriano Pukimapiwëteri, à frente, faz uma fala dirigida aos "brancos" (napë) na festa que celebrava a construção da escola no Pukima Cachoeira, em 2020, projeto que desenvolvemos juntos. Ao fundo, parte do povo do xapono que concordou em aparecer na imagem. 



\section{Sangue da Lua}

Mil anos de guerras, mil anos de festas!

É o que desejo para os Yanomami.

Pierre Clastres (2004, p. 37)

As viagens dos napë (os "brancos", "não-yanomami”) para além dos confins do céu são um tema que com frequência surge nos diálogos com os Yanomami. Certo dia, já de tardinha, no xapono Pukima Beira do Alto Rio Marauiá, conversávamos sobre os astros e o céu e eu contava a um casal atento algumas histórias das viagens dos napë à Lua, conhecida por peripo pelos Yanomami. André, genro do përiomi (a liderança do xapono, isto é, da casa-aldeia), me escutava curioso e rindo, e nos melhores momentos traduzia para sua esposa, Fabíola, as notícias lunares que eu trazia. "Mas pisou mesmo?", ele me perguntava. Eu, que não sou nem de longe um especialista em astronomia, podia apenas afirmar que sim, tentando explicar a tara dos napë pelo espaço, pelo cosmos e pelos supostos seres extraterrestres. As imagens da missão Apollo 11 de 1969 me vinham à mente e eu tentava descrever a cena para eles: pisaram mesmo, com roupas estranhas, colocaram uma bandeira, caminharam, mas a gravidade é outra. E eu me esforçava para imitar o caminhar dos astronautas. A conclusão, dada por André, foi precisa: "É, eu acredito mesmo, do jeito que os brancos são curiosos". E ainda complementou, "os pajés também pensam assim, eles vão até lá e depois contam para nós".

Em uma outra ocasião, o antropólogo norte-americano Roy Wagner passou por situação semelhante. Em um encontro com o pajé yanomam Davi Kopenawa, descrito em uma entrevista de 2011, este o questionou, sem meias palavras: "Você conhece a lua de perto?". O que estava em jogo, entretanto, não eram os eventuais conhecimentos astronômicos ou cosmológicos do conhecido antropólogo, nativo da terra da missão Apollo 11 e que evidentemente nunca havia ido até a Lua, mas formas distintas de conhecer. E Kopenawa continuou, com uma gentil orientação: “Olha, 
quando você chegar lá, quando você for à lua, vai ventar muito forte e você vai ter que se segurar" (Ferrari et al., 2012, p. 968). E anos atrás, na época em que os norte-americanos colocaram o pé sobre o solo lunar, o Padre Luís Coco, que trabalhou muitos anos com os Yanomami do Rio Ocamo na Venezuela, conta que após dar a inédita notícia foi pego por uma inesperada falta de surpresa: "Os napë na Lua? [...] Nós, pajés yanomami, vamos a ela com muita frequência” (1972, p. 427, tradução minha).

Periporiwë, o ser-imagem da Lua, "é o tataravô dos Yanomami" (Cocco, 1972, p. 403). Uma vez flechado, em tempos antigos, seu sangue jorrou para todas as direções do território e ao cair, como chuva, transformava-se em Yanomami, os "filhos do sangue da Lua". O sufixo -riwë em yanomami (como o -ri de Urihinari em yanomam) denomina uma classe de seres-imagem e antepassados míticos atualizados enquanto espíritos ou pajés hekura, isto é, seres hiper-humanos e imortais transformados a partir dos antepassados humano-animais ou humano-vegetais, humano-corpos celestes, humano-fenômenos naturais e humano-objetos dos tempos primeiros. Os hekura (hekura pë, no plural) são também tomados como espíritos auxiliares dos pajés, sendo estes também considerados como hekura, como vimos, e por eles chamados para cantar, dançar e dialogar durante o hekuramou, o "fazer hekura" ou, como dizem alguns yanomami, o "fazer xamanismo". O sufixo -mou transforma o substantivo em verbo e, como indica Jacques Lizot, nesse caso, o morfema -mo-, de desinência verbal, é gramaticalizado com um vocábulo que se refere a "atividades essenciais para o sujeito e a ação afeta os objetos que são considerados como extensões da pessoa" (2004, p. 233). Assim, ao "fazer hekura" (hekuramou), como bem traduzem os Yanomami, o pajé se "espiritiza" (cf. Cesarino, 2011, 2013), efetuando um processo de tornar-se outro através da transformação do corpo e da ativação de características hiper ou extrahumanas, em diálogo com a rede de parentesco e de aliança sociocósmica dos espíritos auxiliares.

Periporiwë, assim, refere-se a um ser dos tempos primeiros, de importância fundamental na mitologia yanomami, e também ao hekura potencialmente perigoso e habitante do céu, em seu xapono celeste, assim como Motokariwë (Sol) e Omayariwë (Arco-íris). Embora sua origem remonte a tempos ancestrais, sua existência e também sua narrativa é constantemente atualizada, afinal, Periporiwë "ainda vive lá, no mesmo lugar onde foi flechado. Não morreu” (Ramirez, 1993, p. 139). Numa das 
vezes que escutei a história de Periporiwë, dias depois de eu ter pedido ao Adriano que contasse a história da ocupação do Marauiá - eixo central desse capítulo, não sem algumas derivações -, a qual ele afirmava saber dela "toda", o përiomi do xapono Pukima Cachoeira inesperadamente chegou em nossa casa, sentou-se na rede, ainda de toalhas logo após o banho no rio, e perguntou-nos, como de praxe, sobre os napë e suas viagens pelo espaço sideral. Conversamos um pouco, contei novamente sobre a estranha missão Apollo 11 e, nas horas seguintes escutamos a história das migrações desde o tempo de Periporiwë até tempos mais recentes, quando os últimos grupos Konapimateri e Momohiteri migraram da Venezuela para a região do Marauiá. Nesta manhã, foi notável como Adriano operou a mediação entre um período de tempo remoto - o tempo dos ancestrais no patapi, este que chamaríamos de "mítico" - e um período mais recente, situando o contexto das migrações dos Yanomami ao Rio Marauiá através de sua respectiva "cosmo-história" (Albert, 2000, p. 18), e assim desvelando como o tempo do "mito" e o tempo da "história" se interpenetram, coexistem e estão em continuidade no pensamento yanomami.

Assim contou o përiomi:

No início, Periporiwë morava em um xapono como o nosso. Periporiwë devorava as crianças, os filhos e as filhas dos parentes. Certa vez, tristes e com raiva de Periporiwë, os moradores do xapono saíram para o mato, saíram de wayumi [expedição de caça e coleta coletiva]. Em determinado momento, um deles voltou correndo, pois havia esquecido algo em sua casa e, ao entrar, encontrou Periporiwë fuçando as cinzas no meio do xapono, catando e comendo os restos de carne e os ossos da criança que havia sido cremada. 'Ũũũũũ', ele gemia e roncava enquanto comia tudo aquilo. O jovem, desesperado, voltou correndo para avisar o pai da criança, Suhirina [Escorpião, em outras fontes descrito como Suhirinariwë, cf. Cocco, 1972, p. 467], que era pajé grande. 'Ele está comendo as cinzas do meu filho?', perguntou, chorando. Suhirina voltou correndo ao xapono com seu irmão mais novo e outros jovens. Uhutimari [antepassado mítico que também se refere a uma espécie de escorpião, ou Uhutimatawë, cf. Ramirez, 1993, p. 138] flechava, flechava, flechava, mas não acertava Periporiwë. 'Tai, tai, tai, tai'. Flechava em vão e Periporiwë, desde o meio do xapono, começou a subir em direção ao céu, ficando cada vez mais alto. Subia, subia, repetindo, 'Peeeriporiwëëë, Peeeriporiwëëë, Peeeriporiwëëë'. Subia em direção à sua casa, 
sua rede estava escondida lá em cima. E quando já estava bem alto, pronto para entrar na sua casa, Suhirina foi atrás dele. Subiu quase até o céu, pegou seu arco, preparou sua flecha, puxou, puxou tão forte que quase estourou a corda, mirou bem e 'taaai!'. Acertou bem no peito. Ele não errou, não, Suhirina acertou com uma só flecha, lá no alto. No lugar que a flecha acertou, o sangue começou a esguichar como uma torneira, para todos os lados. O sangue caía se transformando em gente. Onde caíram gotas mais grossas surgiram os Yanomami mais guerreiros e onde caíram poucas gotas surgiram os menos guerreiros. Aqui caiu pouco sangue. Foi assim que surgiram nossos antepassados. Todos são filhos do sangue de Periporiwë. Todos são filhos do sangue da Lua.

"Na nossa terra, derramou pouco sangue. É por isso que não somos tão valentes como os Yanomami de lá, na terra dos quais derramou muito sangue" (Ramirez, 1993, p. 139), dizia em outros tempos um velho pajé do Rio Marauiá, ecoando a fala do përiomi do Pukima Cachoeira: "Lá para os lados da Venezuela, lá caiu sangue mesmo!”. A marcação da diferença em relação a um outro "de lá" corresponde a uma generalização das relações intercomunitárias classificadas por diferentes graus de alteridade e diferentes regimes de aliança ou hostilidade. São essas distintas formas de relação que fazem desse mito, tal como narrado por Adriano, um "mito da história" (Gow, 2001, p. 93), ao contrário de uma resposta, no sentido de um argumento histórico, à minha pergunta sobre a história da ocupação do Marauiá. Essa história aponta, assim, que a atual configuração socioespacial do Marauiá é apenas um dos pontos de uma linha contínua e inconclusa de transformações que perpassa e também que produz múltiplas gerações de parentes e afins, desde a formação primeira dos diferentes graus de alteridade e dos diferentes regimes de relações intercomunitárias. Segundo Bruce Albert, essas relações intercomunitárias podem ser classificadas em cinco categorias principais que configuram as bases da filosofia política e social yanomami: co-residentes, grupos locais aliados, pessoas hostis/inimigos atuais, inimigos virtuais/antigos, inimigos potenciais desconhecidos (1985, p. 193). Essas categorias são ainda projetadas virtualmente em uma cartografia de espaços sociopolíticos representados, esquematicamente, por círculos concêntricos. Dessa forma, à medida que as relações entre grupos se distanciam - partindo de um centro de co-residentes e dirigindo-se aos círculos exteriores até os inimigos desconhecidos - alteram-se o graus das relações de afinidade 
Fig. 06. "Poriporiwë, o espírito da lua, é muito feroz e por isso os outros espíritos o temem, ele pode devorar o ser maléfico Kamakari" (Iramari Yanomami; Machado, 2014, p. 59). Desenho de Joseca Mokahesi Poroaunahiki thëri Yanomami (2014).

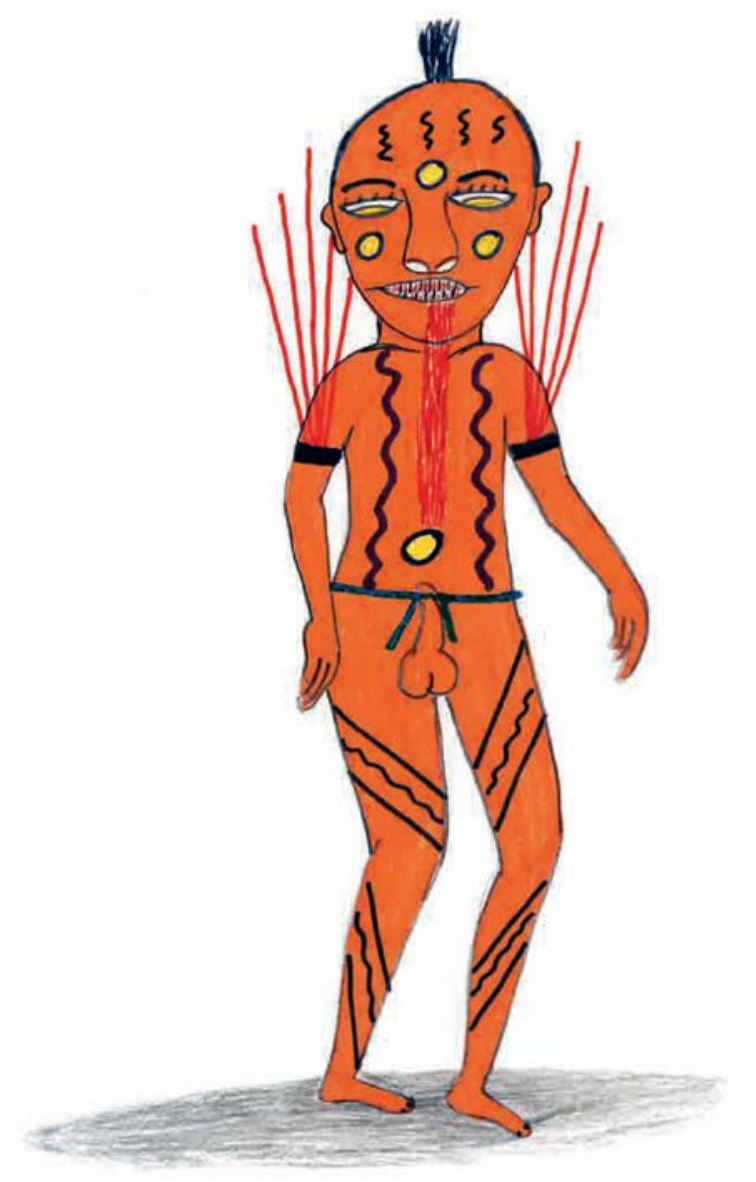


potencial (Viveiros de Castro, 2002), bem como a forma ou intensidade das relações hostis reais ou virtuais, potencialmente convergindo na troca de agressões físicas ou xamânicas.

No caso da cartografia mítica e prototípica estabelecida pelo sangue de Periporiwë, o grau estabelecido varia desde os co-residentes e os grupos locais aliados - cuja valentia, como diz o pajé do Marauiá, pode ser útil para somar forças para um eventual conflito com os demais grupos - até os outros que, segundo o pensamento mítico e a filosofia política yanomami, configuram os afins potencialmente inimigos. A história de Periporiwë, portanto, não trata apenas da origem da Lua e da origem dos Yanomami, mas, assim como nos mitos pan-ameríndios associados ao tema da Lua, serve a uma "mitologia da ambiguidade" (Lévi-Strauss, 2006, p. 98). Nesse caso, instaura uma oposição entre vida e morte (cf. Carrera Rubio, 2004 p. 149-161) e também uma oposição relacional entre os "mais guerreiros" (mais distantes) e os "menos guerreiros" (mais próximos), com o respectivo estabelecimento dos contínuos conflitos e ataques guerreiros, pois como retratam outras versões do mito: "O sangue caía se transformando logo em gente [...] que imediatamente flechava. [...] O sangue desceu flechando e não se esgotou. Os Yanomami, formados a partir do sangue da lua, mataram os habitantes do xapono do flecheiro de Lua [Periporiwë]" (Ballester, 2017ª, p. 100-101).

As flechas que atingem Periporiwë e fazem com que seu sangue "caía se transformando logo em gente" ressoam com outro mito sobre o surgimento da Lua, nesse caso uma narrativa do povo Marubo da Amazônia ocidental (Cesarino, 2013, p. 257-282). Nessa narrativa, o desfecho do ser Temĩ Txoki, antes de sua transformação final em Lua, implica também num ato de hostilidade e agressão. Ao invés de uma saraivada de flechas, Temĩ Txoki é esquartejado após uma certa desobediência dos critérios próprios de um povo outro com o qual se relacionava. As partes cortadas de seu corpo originam as sucuris e, num procedimento comum à mitologia marubo, desencadeia surgimentos diversos, seja a partir do sangue - de forma análoga ao sangue de Periporiwë -, das partes do corpo ou dos duplos que desprendem do invólucro corporal (Cesarino, 2013, p. 276, nota 29). Como indica Pedro Cesarino é num "sentido etiológico peculiar" que essa "violência decorrente da relação entre pessoas de distintas posições (...) dá origem às características do cosmos atual, cujas qualidades e elementos derivam, mais uma vez, do corpo como matéria 
de transformação privilegiada pelo pensamento mítico" (2013, p. 258). Esse sentido, portanto, é partilhado de alguma forma pela narrativa de Periporiwë, cuja mitologia da ambiguidade, justamente, resulta dessa violência etiológica, onde "o sangue caía se transformando em gente" e, como dizia Adriano, "onde caíram gotas mais grossas surgiram os Yanomami mais guerreiros e onde caíram poucas gotas surgiram os menos guerreiros".

A oposição entre "mais guerreiros" e "menos guerreiros", em outros contextos, pode também ser indicada pelo par waika/xamatari. Em síntese, trata-se de uma oposição sociológica e geográfica que indica os outros, os "mais guerreiros", de modo que normalmente não corresponde a grupos locais específicos e tampouco a uma autodesignação, já que waika/xamatari são sempre os "de lá". De modo aproximado, waika indica os Yanomami ao norte e ao leste do grupo de referência, enquanto xamatari indica os que se encontram ao sul e a oeste. No Marauiá, por exemplo, o termo waika abrange desde os grupos yanomami de Roraima, ao norte e ao leste, até alguns grupos distantes, do outro lado da serra, da Venezuela, ao norte. No sentido contrário, de Roraima para o Amazonas ou para a Venezuela, por exemplo, o termo genérico utilizado para se referir aos Yanomami da região é xamatari. Outra narrativa em torno da criação dos primeiros Yanomami pelo sangue da Lua, coletada por Hans Becher e publicada em 1974, oferece um raciocínio interessante para essa dualidade, sintetizando o par waika/xamatari e situando-o no território (brasileiro, pelo menos): “[...] exatamente como na lua e no primeiro céu havia uma metade oriental e uma ocidental, aqui foi dividido pelo Rio Padauairi" (Wilbert; Simoneau, 1990, p. 48, M15).

Xamatari, no entanto, pode ter um significado distinto ao se referir a um subgrupo linguístico ou dialeto específico e aos Xamatari "de verdade", isto é, a um grupo ou a um conjunto de grupos ancestrais, como é o caso entre os Yanomami do Marauiá que se incluem nas duas categorias. Os Xamatari "de verdade" estão associados ao antigo e grande xapono dos Aramamisiteri, localizado aproximadamente nas cabeceiras do Rio Rahuawä e Xukumöna (ou Matapiri e conhecido oficialmente como Rio Siapa, afluente do Canal Casiquiare), na região montanhosa da Serra de Unturan entre as cabeceiras do Rio Orinoco e Mavaca, na Venezuela. Conta-se que essa denominação surgiu no antigo grupo que habitava ao norte do Orinoco onde seu líder era chamado de Xamatari dada sua corpulência, comparável à de uma anta, xama. Assim, quando esta 
comunidade se dividiu no final do século XIX, teria sido essa liderança que conduziu o grupo, atravessando o Orinoco até as cabeceiras do Rio Siapa, dando origem aos Aramamisiteri e, provavelmente, difundindo a acepção do termo Xamatari para todos aqueles que migram ao sul do Orinoco (Valero, 1984, p. 542). A partir dos relatos dos Yanomami e também de autores como Luis Cocco (1972) e Helena Valero (1984), pode-se concluir que o grupo dos Aramamisiteri se dividiu posteriormente em pelo menos três grandes grupos: os Xamatari, os Kohoroxitari e os Karawëtari, sendo que os últimos são os que se estabeleceram no Rio Marauiá.

Estima-se que foi no início do século XIX que grupos yanomami vindos da Serra Parima desceram pelo seu lado meridional até as cabeceiras do Rio Orinoco, atravessando-as e ocupando as terras entre o Orinoco, o Mavaca e o Siapa (Cocco, 1972, p. 26). A região da Serra Parima, situada no interflúvio entre o Alto Rio Orinoco e o Alto Rio Parima, na fronteira do Brasil com a Venezuela e nas terras altas da região do Escudo das Guianas, é compreendida como local de origem dos Yanomami (e ainda densamente ocupada), segundo a tradição oral yanomami registrada por diversos autores, mas também de acordo com registros de fontes antigas (a partir século XVIII) e de análises linguísticas históricas (cf. Migliazza, 1972). Esse período entre os séculos XVIII e XIX, em particular, foi marcado por um intenso movimento, com grandes migrações e ampla expansão do território e da população yanomami para todas as direções do território. Os movimentos que caracterizam esse período foram realizados em menor e maior escala de distância, desde mudanças e fissões de grupos abrindo roças e clareiras em regiões não tão distantes das anteriores até grandes ou constantes mudanças em função de conflitos guerreiros entre grupos yanomami (Migliazza, 1972). Nessas regiões, os Yanomami ocupavam territórios de outros grupos desestabilizados pelas frentes de expansão colonial ou também em migrações constantes (como os Caribe, que migravam ao norte), ou as conquistavam através do contato e do conflito com povos Aruaque (Arawak), ao sul e a oeste, e povos Caribe (Karib, Carib), ao norte e ao leste. As hipóteses geográficas, como essas, assim como as econômicas e tecnológicas, relacionadas à introdução de objetos metálicos e do cultivo da banana-prata, para o exponencial aumento demográfico nesse período não são, afinal, nada mais do que hipóteses sustentadas por parcos dados concretos, como relembra Albert (1985, p. 38), e tampouco são objeto de atenção deste trabalho. Enfocaremos aqui, 
portanto, os deslocamentos entre os grupos Xamatari e, especificamente, dos Karawëtari que por volta da década de 1920 atravessaram a fronteira entre Brasil e Venezuela (Cocco, 1972, p. 26), passando a ocupar as cabeceiras do Rio Marauiá, afluente do Médio Rio Negro com cerca de $180 \mathrm{~km}$ de extensão, conhecido tradicionalmente por Komixipiwëi u.

Os antigos Karawëtari são os antepassados da maior parte dos grupos que atualmente habitam a região do Rio Marauiá. Além deles, há também os grupos dos Konapimateri (que migraram por volta dos anos 1980) e os Momohiteri (de migração mais recente) no afluente do Alto Marauiá conhecido como Rio do Kona e tradicionalmente como Hetumisiri, que significa algo como rio do "povo do céu". Os Konapimateri e os Momohiteri compartilham com os Karawëtari a região de origem e a descendência dos antigos Xamatari: "são parentes", aliados atualmente e inimigos antigamente. No entanto, apesar dos Konapimateri e dos Momohiteri possuírem relações de aliança com os grupos do Marauiá, têm vínculos de parentesco mais estreitos com os grupos que habitam a região do Alto Rio Padauari, no Rio Marari, e com grupos do lado de lá da fronteira, ambos de origem Xamatari. Mesmo assim, os atuais dezessete grupos que habitam a bacia do Rio Marauiá, assim como um grupo da mesma origem mas que vive no Rio Preto, afluente do Padauari, são representados politicamente através da Associação Kurikama (fundada em 2013). Os grupos do Marari, por sua vez, são historicamente aliados dos grupos do Marauiá e ainda hoje empreendem visitas mútuas, seja para estabelecer trocas ou comparecer às festas funerárias reahu, especialmente no caso dos Konapimateri e dos Momohiteri. Conforme relatos das antigas incursões guerreiras contra os ditos Kohoroxitari - "os excrementos de minhocas", autodenominados atualmente por Masiripiwëteri, sendo que o primeiro é um termo pejorativo dado pelos Karawëtari e assim consolidado na bibliografia antiga - da região do Rio Maturacá, Cauaburi e Maia, afluentes do Alto Rio Negro, com frequência estas eram feitas em conjunto com os grupos do Marari. O último conflito guerreiro entre os Masiripiwëteri e os Karawëtari do Marauiá ocorreu por volta dos anos 1960 (Re; Laudato, 1984, p. 34).

Karawëtari e Kohoroxitari partilham a mesma filiação Xamatari e a mesma região de origem, nas terras altas entre o Alto Rio Mavaca e Orinoco, na Serra de Unturan. Os Kohoroxitari foram os primeiros a migrar para a bacia do Rio Negro, atravessando a Serra do Tapirapecó e a fronteira entre 
Brasil e Venezuela, por volta de 1920. Era um período de muitos conflitos e também de intensa mobilidade e grandes migrações. Segundo o përiomi do xapono Pukima Cachoeira, os Karawëtari e Kohoroxitari habitavam uma mesma região e, possivelmente, um mesmo xapono, "xapono grande mesmo". Os Kohoroxitari, segundo ele, foram os primeiros a se dividir, fugindo dos conflitos com os demais grupos Xamatari e também com os próprios Karawëtari. Atravessaram o Rio Siapa e, provavelmente, seguindo o curso do igarapé Castaño em direção às cabeceiras, atravessaram a Serra do Tapirapecó, atingindo as cabeceiras do Rio Padauari, no alto curso do afluente Marari. Do Alto Marari, seguiram para a região do Alto Marauiá, atravessando o Rio do Kona e o Rio Pukima ("mutuca", espécie não identificada), ambos afluentes do alto curso do Marauiá. Atravessaram a Serra do Imeri, onde encontra-se o Pico da Neblina, conhecido por yaripo, "montanha do vento", e seguiram rumo ao Rio Maiá, no alto Cauaburí, e ao Maturacá, região que habitam desde então.

Os Karawëtari seguiram os caminhos abertos pelos Kohoroxitari rumo ao lado da serra em território brasileiro. Segundo o përiomi do Pukima Cachoeira, seus avôs e tataravós iam guerreando, se apossando, ocupando e morando nos acampamentos que os ditos Kohoroxitari deixavam para trás em fuga. Os Kohoroxitari faziam novas roças e eram novamente espantados pelos Karawëtari. Segundo relata Adriano, tal como registrado por Tamara Miranda, os Kohoroxitari "faziam xapono e os Karawëtari já faziam guerra e os espantavam, depois mudavam-se para seu xapono e comiam a comida deles" (2020, p. 40). O conflito entre os dois grupos, portanto, persistiu durante a longa migração. Na verdade, os processos são concomitantes e na medida em que os Karawëtari se aproximavam, fugindo de outros conflitos com os Xamatari, empurravam cada vez mais os Kohoroxitari, assim ampliando exponencialmente a distância percorrida nessa longa caminhada. Atrás desses grupos, os Xamatari também migraram ao sul, habitando a região do Alto Mavaca e, um dos grupos, os Abruwëteri, atravessaram também a fronteira e se estabeleceram no Marari, na mesma época (Cocco, 1972, p. 26). Uma vez estabelecidos e separados dos Kohoroxitari pela Serra do Imeri, os Karawëtari se estabeleceram aos poucos na região do Marauiá, passando uma série de moradas mais efêmeras em função dos constantes conflitos com grupos próximos, como os Posikomimateri, e habitando em sucessivos acampamentos na floresta, em locais conhecidos como Xekerei (próximo às 
cabeceiras do Marari), Apiapihiwëi (próximo do atual Kona), Hõriapiwëi, Yãimoropiwëi e Xitipapiwëi (voltando às cabeceiras do Marauiá e do Pukima). Passado algum tempo de muitas andanças e acampamentos, e buscando refúgio dos conflitos com os Posikomimateri, abriram o grande xapono Hayanae na região do Rio Kapirota, próximo das cabeceiras do Igarapé Rapi Rapi, atualmente conhecido por Rio do Pohoroa (cacaueiro, Theobroma cacao), nas cabeceiras do Rio Marauiá. Como resume Adriano: "Primeiro os Karawëtari moravam num xapono que era dos Kohoroxitari, chamado Xitipapiwei, e quando viram que os inimigos já estava longe, subindo e descendo, subindo e descendo a serra, resolveram fazer um xapono deles mesmo e fizeram o Hayanae. Assim que foi".

Nessa época, de data incerta (entre a década de 1920 e 1950), o Hayanae era o único xapono do Marauiá e concentrava os antepassados dos grupos que depois se dividiram até a configuração atual, mas ainda dinâmica, das comunidades que lá habitam. Segundo conta-se, o xapono era "grande, grande mesmo". A escala do xapono destoa dos padrões demográficos dos antigos grupos locais e nos relatos dos próprios Yanomami esta adquire um curioso aspecto mítico. Como relata Tamara Miranda, certa vez um jovem do xapono Bicho-Açu lhe descreveu o Hayanae da seguinte maneira: "era muito grande, se vocễ sair hoje, não chega não [do outro lado], tem que dormir no caminho" (2020, p. 52). Conta ela também de uma descrição semelhante sobre o antigo xapono dos Aramamisiteri que, segundo seu interlocutor Konapimateri, eram os verdadeiros Peripoiyëteri, ou seja, os que realmente nasceram do sangue da Lua: "lá onde tinha o xapono dos Aramamisiteri, os antepassados dos Konapimateri, Momohiteri, Toxamoxiteri, Xamatari, Apruwëteri, Kepropëteri, Karawëtari e Kohoroxitari viviam todos juntos" e, assim como Hayanae, por lá "não chega rápido do outro lado quando passeia [caminhando ao redor do círculo de casas do xapono]" (2020, p. 52).

Segundo Maurício Iximawëteri é o ser-imagem da Jibóia, por meio de seu canto, que diz aos pajés o nome que devem dar aos locais que habitam os Yanomami (Miranda, 2020, p. 39). O nome Karawëtari faz referência à serra Karawë, próximo de um igarapé de mesmo nome, nas cabeceiras do Rio Siapa e, provavelmente, próximo também do xapono Aramamiseteri, onde habitavam os antigos. Locais de moradia anteriores ao Aramamisiteri não são nomeados atualmente e segundo alguns interlocutores Yanomami teria sido ali mesmo que surgiram, conectando 


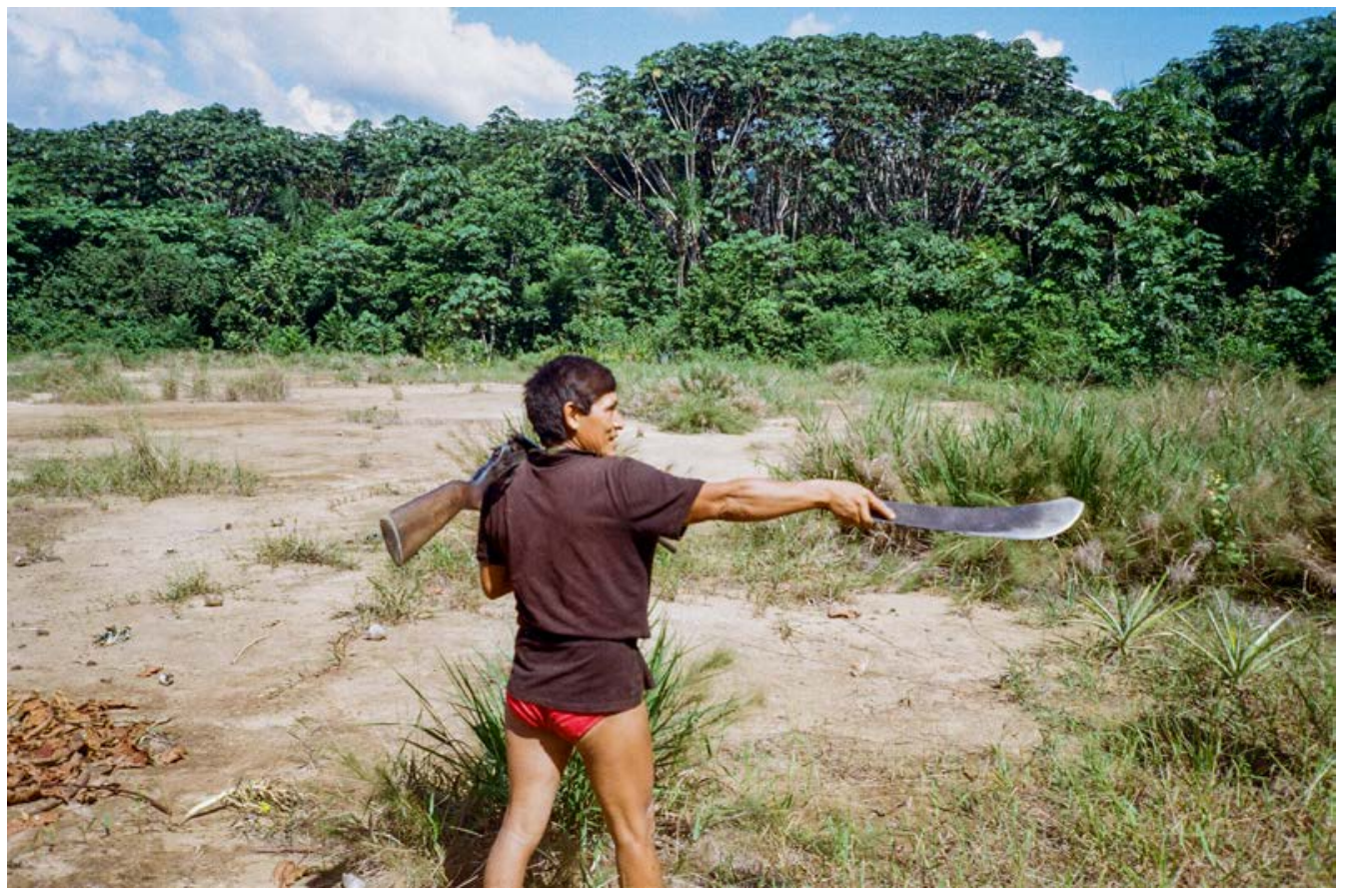

Fig. 07. Adriano Pukimapiwëteri, na clareira do antigo xapono Pukima Cachoeira, a caminho de sua roça de bananas no sopé das serras (2019). 
suas origens agora não com o mito de origem da Lua, como no relato acima, mas com outro importante mito de origem, conhecido pelo mito do "homem da panturrilha grávida" ou das "primeiras mulheres" (cf. Lizot et. al., 1993, p. 84-85): "Meus antigos surgiram na Venezuela, são os Karawëtari. Onde tem a serra Karawë, foi lá que eles surgiram primeiro, antes disso havia ső o povo que nasceu da perna daquele homem" (Miranda, 2020, p. 50).

Ao que parece o grupo Karawëtari continha em si uma subdivisão em quatro grupos menores, todos compartilhando nominações a partir de elementos da paisagem da região situada nas cabeceiras do Rio Siapa, o que reforça o dado de que são oriundos dessa região: Warapawëteri, Amianateri, Maneiwëteri e Heweriwëteri (Valero, 1984, p. 541). O nome Karawëtari, convencionalizado como referente histórico e identitário desse período, atualmente é utilizado apenas ao se referir às histórias antigas. Na esfera local este não é mais usado como forma de se definir, mas ainda pode ser o nome pelo qual os grupos do Rio Marauiá são reconhecidos por outros Yanomami de outras regiões. Conta Miranda que os Konapimateri muitas vezes se referem aos outros Yanomami do Marauiá como "os Karawëtari” (2020, p. 54). Além disso, em contextos de assembleias onde se reúnem grupos Yanomami de diversas regiões do Brasil e da Venezuela, as designações mais antigas ainda são eficazes: "Adriano [përiomi do xapono Pukima Cachoeira] esteve em Puerto Ayacucho na Venezuela participando de um evento [o seminário "Direitos Indígenas y políticas nacionales: analizando el caso de los Yanomami de Venezuela y Brasil" em 2013] e conta que, ao se apresentar para os outros Yanomami, identificou-se como Karawëtari, nome usado por seus antepassados. Assim o fez porque aqueles grupos de regiões distantes e com os quais não mantém contato conhecem apenas esta denominação mais antiga, do tempo anterior ao que os Karawëtari cruzaram a fronteira da Venezuela" (Miranda, 2020, p. 54).

O único registro contemporâneo a esse período de intensos conflitos e mudanças encontra-se no famoso relato de Helena Valero, a napëyoma ("mulher branca") que viveu mais de duas décadas com os Yanomami. Em 1933, os ditos Kohoroxitari se depararam com a canoa da família de Helena Valero nas cabeceiras do Rio Demiti (Dimití), afluente do Alto Rio Negro, e atacaram com flechas, interessados sobretudo nos facões, machados e outros bens que ali estavam. A família de Helena Valero, embora ferida, 
conseguiu fugir e a jovem garota de 14 anos de idade ficou para trás. A jovem foi capturada pelos Kohoroxitari e levada ao acampamento nas imediações do conflito, no extremo oeste do seu território. Segundo o relato, permaneceu alguns dias do acampamento e com os Kohoroxitari empreendeu uma longa viagem de volta às cabeceiras do Cauaburi, onde tinham seu xapono. Após um conflito com um grupo Xamatari do Alto Orinoco, os Matakïwëteri, o grupo Kohoroxitari se mudou para outra localidade, construíram um novo xapono e foram atacados pelos Karawëtari. Junto de outras mulheres, Helena Valero foi capturada pelos Karawëtari e se mudou, caminhando para lá da Serra do Imeri, na região do Alto Marauiá.

Helena Valero viveu apenas uma semana com os Karawëtari, por volta dos anos de 1933 e 1934. Conta ela que no caminho passaram no antigo acampamento Huriãpiwei dos Karawëtari, "assim chamado porque, ao pé da colina huria [e do igarapé, de mesmo nome], havia muitos pés de huria [huriã anahi, Clarisia ilicifolia, um pequeno fruto comestível]" (1984, p. 55), consoante com os relatos dos antigos locais de acampamento tal como relatado acima. Foi nesse mesmo local que os Karawëtari acamparam na viagem de ida, quando iam ao encontro com os Kohoroxitari, e nos mesmos tapiris passaram a noite, após refazerem as coberturas dessas estruturas conhecidas em yanomami por yãno: "As mulheres trouxeram folhas de miyõma e começaram a reformar os telhados. Essas folhas são usadas e, em seguida, carregadas até o lugar seguinte, se não houver certeza de encontrar novas, como desta vez. A folha de miyõma [miyõma henakí, Geonoma sp.] é dura e resistente, e não se encontra onde há savana" (1984, p. 55). Durante a primeira noite com os Karawëtari, relata ela, os përiomi discutiam as tarefas do dia seguinte e, logo ao amanhecer, se puseram a limpar o antigo xapono e a buscar palha para cobrir a antiga casa: "O dia todo carregando folhas. Era grande essa maloca, porque era grande a tribo dos Karawëtari. Depois de três dias de trabalho nós entramos [saindo do acampamento e voltando ao xapono reformado e retomado]. Estava bonito, limpo" (Valero, 1984, p. 55). Noutra fonte, Helena Valero conta ainda que "o xapono era muito grande; maior até do que o dos Kohoroxitari [...]. Os Karawëtari eram muito mais numerosos que os Kohoroxitari. Eram mais de cem e tinham muitas mulheres e crianças" (Biocca, 1996, p. 45).

Dias depois chegaram visitantes ao encontro dos Karawëtari e estes 
foram convidados pelos Xekereiteri (ou Hekurawëtari, variando entre as fontes) para um reahu, uma festa funerária, em seu xapono no Matapiri, afluente do Alto Rio Siapa, e a garota seguiu com eles (Valero, 1984, p. 61; Cocco, 1972, p. 105). Como estavam sob constante alerta da vingança dos Kohoroxitari e tinham acabado de fazer uma grande viagem, apenas parte do xapono aceitou comparecer e Helena os acompanhou. Conta ela que foram subindo pela serra Huriãpiwei, e após dias andando pela região da Serra do Tapirapecó chegaram ao antigo acampamento Xitipapiwei, cheio de palmeiras (pupunheiras, provavelmente) e de cacau, onde havia um xapono abandonado no pé da montanha de mesmo nome. Conta ela que esse era um acampamento antigo dos Kohoroxitari e, de acordo com os relatos dos antigos acampamentos dos Karawëtari, também um antigo xapono tomado por estes e, nesse momento, reativado como acampamento durante a longa viagem. A partir daí, sua história vai longe e, curiosamente, refaz o caminho das migrações históricas do período de expansão demográfica e territorial, mas pelo sentido inverso, indo de sul à norte, saindo das imediações do Rio Negro até o Orinoco.

A estada de Helena Valero entre os Karawëtari aconteceu, provavelmente, pouco antes do grupo se estabilizar e fundar o xapono Hayanae. Nos relatos que os Yanomami fazem sobre esse período, a história da ocupação e dos xapono do Marauiá costuma partir do Hayanae, provavelmente por esse caráter de maior estabilidade e, também, de maior escala, ao que parece, juntando os grupos que poderiam estar dispersos em acampamentos pela mata. Algumas pessoas nascidas nesse xapono ainda estão vivas e estima-se que sua cisão ocorreu em meados da década de 1950. Nesse momento, o xapono que era o único a ocupar a região do Marauiá se dividiu em quatro grupos, provavelmente os mesmos quatro grupos familiares com nomes relacionados às cabeceiras do Rio Siapa, como mencionado acima. Liderados por quatro "grandes chefes", përiomi, estes grupos já mantinham certa autonomia uns em relação aos outros e, conforme relatam, costumavam se movimentar separadamente pela floresta, acompanhados de seus familiares, nas épocas de conflitos guerreiros ou de expedições de caça e coleta coletiva, wayumi (Miranda, 2020, p. 53). Com a mudança, os nomes dos grupos e dos xapono também foram atualizados em função dos novos territórios que passavam a ocupar, entre sopés de serras e rios e igarapés, e surgiram, então, os Ironasiteri, Xamatawëteri, Pohoroawëteri e Pukimawëteri. 
As construções dos novos xapono, no entanto, não foram imediatas. Foi o caso dos Pukimawëteri, grupo que serve de ponto de partida para esta etnografia. Entre a cisão do Hayanae e o assentamento no xapono Pukima, este grupo habitou em moradas temporárias e acampamentos em diferentes regiões, dentre elas as conhecidas por Purimapiwëi, Masiripiwëi e Pukimapiwëi. Os nomes desses lugares correspondem aos nomes dos igarapés (nas cabeceiras do Rio Pukima) e das serras em cujos sopés se situavam os acampamentos. Segundo contam os antigos, nascidos em sua maioria em algum desses acampamentos, nesse mesmo período (provavelmente entre as décadas de 60 e 70) foram atingidos por uma epidemia de sarampo, transmitido quando de uma visita a uma parte do grupo dos Xamatawëteri que migrou para a região do Rio Padauari e estabeleceu contato com as populações de extratores de piaçava locais. De volta à região do Marauiá, partes do grupo Pukima se separaram, saindo de wayumi como que de quarentena, evitando o contágio generalizado até que estivessem curados, o que explica a grande variedade de locais de morada provisória no mato. Não apenas por isso, mantinham-se ainda movimentos intensos, com muitas expedições guerreiras e saídas de wayumi para caça e coleta de frutos. Por essa razão, isto é, por conta dessa instabilidade em se estabelecer em um mesmo local, com o grupo coeso e saudável, ao se referirem aos locais que habitaram no passado antes do estabelecimento do xapono Pukima, os associam a acampamentos temporários, com círculos de yãno numa clareira improvisada em meio à mata, e não exatamente a aldeias, com os terreiros limpos e círculos de casas (yahi), menos temporárias e mais duráveis, conformando um xapono. Dessa forma, ao relatarem o passado ou o xapono de origem dos Pukimawëteri a principal referência é o xapono Pukima, de forma análoga à menção ao Hayanae em se tratando dos Karawëtari.

Com a cisão do Hayanae, deu-se continuidade ao processo de expansão do território yanomami que se arrastava desde o século XVIII e nesse período, apesar de ocorrer em outra escala, acabam por se definir os limites do território posteriormente demarcado (no lado brasileiro). Nesse momento, conta-se que os Ironasiteri teriam avistado estranhos, uma gente outra, no baixo curso do rio, durante uma expedição de caça e retornaram ao xapono para alertar todos. Soube-se depois que os que foram vistos pelos Ironasiteri eram grupos remanescentes de povos de língua aruaque (arawak) conhecidos por Yabahana, e que trabalhavam 
na região extraindo seringa, provavelmente misturados com caboclos da região. A história do conflito subsequente é famosa e me foi contada por um velho do xapono Bicho-Açu, atual morada das famílias de origem Ironasiteri, situado no baixo curso do rio onde literalmente se tropeça em cacos de cerâmica e achados arqueológicos dos grupos yabahana que lá habitavam. O resumo da trama é o saldo de cinco Yabahana flechados e mortos, dois Ironasiteri também mortos e a fuga dos Yabahana e da população que lá morava, abrindo os caminhos para a continuidade da expansão territorial yanomami quase até a foz do Marauiá com o Rio Negro. A data do conflito é incerta, mas sabe-se que foi somente após o ocorrido, e já nessa configuração socioespacial em expansão, digamos, que o padre e missionário Antônio Goes encontrou os grupos da região do Marauiá e estabeleceu os primeiros contatos no ano de 1958 (Cocco, 1972, p. 96).

Antes disso, em 1954, o padre havia fundado a primeira missão salesiana entre os Yanomami, a Missão Nossa Senhora de Lourdes, na região habitada pelos Kohoroxitari, temidos na região em função de conflitos com as populações locais e com quem o padre travou os primeiros contatos em 1952 (Re; Laudato, 1984, p. 34). Os Kohoroxitari, aos poucos e provavelmente na medida em que o padre começava a lhes entender, revelaram a Antônio Goes a presença de outros grupos yanomami, em uma região próxima, do outro lado da Serra do Imeri e do Pico da Neblina, os velhos inimigos Karawëtari. Em 1962 o padre funda a Missão Sagrada Família no Rio Marauiá, na margem oposta e na mesma altura do afluente Rapi Rapi, conhecido atualmente como Rio do Pohoroa e onde já habitava o grupo de mesmo nome (Re; Laudato, 1984, p. 35).

Na região do Marauiá, Antônio Goes fez contato primeiramente com o pequeno grupo Ironasiteri que havia descido ao baixo curso do rio, chegando até o Rio Negro e, em seguida, com os Xamatawëteri (Cocco, 1972, p. 96), junto aos quais se estabeleceu em 1962. Conta-se que, subindo o Marauiá até a boca do Rapi Rapi, aproximadamente no médio curso do rio, o padre seguiu a trilha que o conduziu até o sopé da Serra Xamata (xama significa "anta", Tapirus terrestris), na margem oposta da Serra do Imeri, e encontrou o grupo Xamatawëteri. Segundo Luís Laudato, padre que assumiu a missão junto de seu irmão Francisco anos após a morte repentina do Pe. Goes em Manaus, a "técnica" usada pelo seu antecessor era de "logo distribuir as ferramentas indispensáveis 


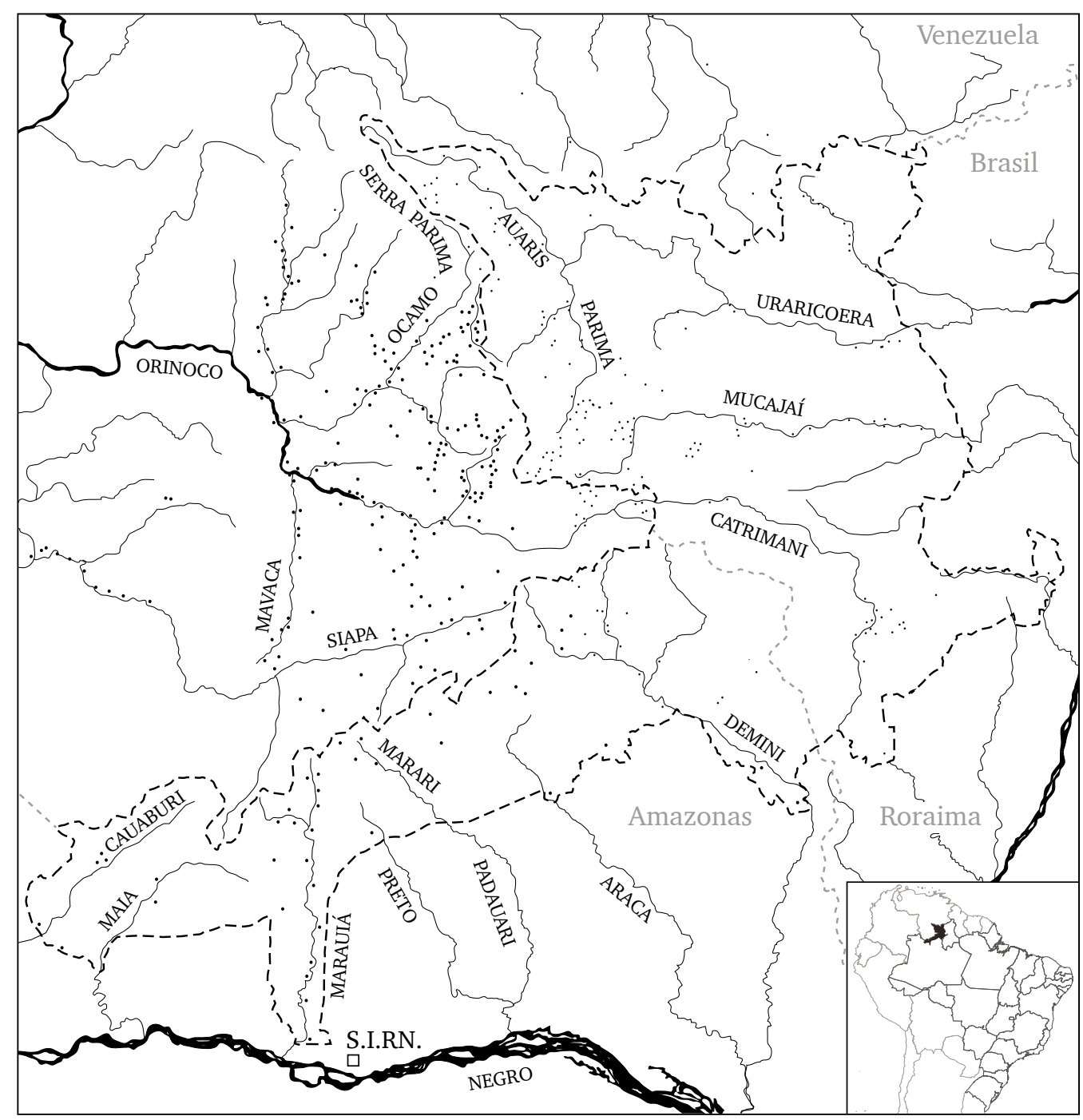

Fig. 08. Mapa geral do território yanomami (entre Brasil e Venezuela), com a Terra Indígena Yanomami indicada em linhas tracejadas (no lado brasileiro), e, de forma aproximada, pontos que correspondem à distribuição dos grupos locais pelo território (adaptado de mapa binacional elaborado pelo Instituto Socioambiental em 2014). 
para iniciar o cultivo de produtos agrícolas", supostamente para resolver as "crises periódicas de falta de alimentos pelas secas imprevistas que, às vezes, assolam as matas amazônicas" (Laudato, 1998, p. 58, nota 20). E, dito isso, Laudato explica:

O padre já conhecia a língua e, com certeza, foi mais fácil o encontro e mais rápido convencer os Karawëtari a descerem para as beiras do Marauiá, para derrubarem um bom pedaço de mato, para ajuda-lo a construir a sua casa e, ao mesmo tempo, o novo xapono, para tornar mais prático o escoamento dos produtos agrícolas que iriam produzir, no futuro (Laudato, 1998, p. 58).

Assim, na base da troca de ferramentas por serviços, sob a pretensa ideia de produção agrícola do padre civilizador, os Xamatawëteri aproximaram-se das margens do Marauiá e deram início a um movimento que se estendeu até a primeira década dos anos 2000 com a mudança do último xapono "no mato" para próximo do rio, o dos Pukimapiwëteri.

Conta-se que os padres presentearam os xapono distantes da missão ou da beira do rio com canoas, uma para o Pohoroa, outra para o Ironasi e outra ao Pukima. A proposta, conforme me foi relatado por Adriano, era "pensar sobre" a ideia de se aproximar das margens do Marauiá para facilitar o acesso dos serviços de saúde e educação fornecidos ou mediados pelos salesianos. Ainda a remo, as canoas abriram um novo eixo de circulação no território do Marauiá e também um eixo de acesso à cidade e à missão. Na subida, à montante, deixava-se a canoa atracada na missão e o restante do caminho era feito a pé, no caso do Pukima, em dois ou três dias de caminhada, acampando no mato, construindo e habitando os tapiris (yãno).

Nessa época, o përiomi do xapono dos Pukimapiwëteri era Cândido, o pai de Adriano, atual liderança do xapono Pukima Cachoeira. Seu pai foi um grande guerreiro e é um dos grandes pajés do Marauiá, respeitado rio acima e rio abaixo. Segundo conta Adriano, seu pai tinha uma boa relação com o Pe. Goes, mas sempre com uma certa reserva, mantendo a distância e recusando os "convites" do padre para que se mudassem para uma localidade mais próxima da beira do Marauiá ou mais próximo da Missão, para facilitar o contato e as trocas e para que seu filho mais velho, Adriano, pudesse estudar a língua portuguesa na escola da Missão. Ao invés de mudarem-se, o antigo chefe teve uma ideia melhor e enviou o filho para estudar, "para aprender português para lutar melhor", conta Adriano. A noção de estudar, evidentemente, não era partilhada 
exatamente nos mesmos termos entre o padre e o përiomi, pois se para um a educação era uma forma de estimular a autonomia dos indígenas no trato e no papo com os brancos, ao mesmo tempo que uma via para catequização, como relata Adriano, para os outros a tal educação era e é uma via de gerar autonomia no trato e nas trocas, mas com um propósito e uma finalidade divergente, isto é, para resistir, reagir, recusar e moverse contra a catequização, contra as políticas discriminatórias e contra as medidas espoliadoras do Estado e dos napë, como bem faz Adriano desde que foi expulso da escola salesiana ainda jovem, "por arrumar muita confusão".

Além do Pe. Goes, o antigo përiomi manteve também boas relações com os irmãos Laudato, que assumiram a missão em 1978, com as mesmas ressalvas, reservas e técnicas de recusa. As trocas de bens e serviços com ambas as gerações de padres eram mútuas, embora também equívocas, como no caso das espingardas fornecidas por Antonio Goes para a caça e não para a guerra contra os Kohoroxitari. Em diferentes momentos, no entanto, todos os xapono do Marauiá aproximaram-se das beiras do rio, facilitando o acesso não apenas dos salesianos, mas também dos serviços de saúde (através da Funai, Funasa e Sesai, por parte do Estado, e da Secoya, organização não-governamental, em diferentes períodos) e de educação (pelos salesianos, pela Secoya e pelo Estado, além de oficinas providas por Anne Ballester).

Foi através dessas relações de contato, iniciadas com a missão salesiana, mas intensificadas e consolidadas com a implantação do sistema de saúde a partir da década de 1990, no entanto, que várias mudanças, cisões e movimentações conformaram a atual forma de ocupação das margens do Marauiá. Através de interesses de aproximação e atendimento por parte dos indígenas, simultâneos aos pedidos de aproximação por parte do Estado - preocupado com a logística e a viabilidade do empreendimento público de atendimento -, gerou-se transformações nos modos de ocupação da terra-floresta, tanto de ordem territorial quanto, digamos, arquitetônica, como veremos no decorrer desse trabalho. E, com isso, os efeitos dessa aproximação às margens dos rios e a consolidação do Marauiá (assim como os afluentes Rio Pukima, Kona e Pohoroa) como fluída via de acesso (embora ainda complicada por conta das cachoeiras e corredeiras que dificultam a viagem) geram ainda hoje ressalvas e acenos ao "tempo que a gente morava na serra", como o próprio Adriano costuma 
dizer com certa nostalgia.

Nesse processo de contato, é também notável como as relações com os napë fazem com que estes transitem entre as categorias que configuram as bases da filosofia política yanomami. Antigamente, como relata Adriano, esses estranhos forasteiros eram conhecidos como os Poowëteri, "povo do machado" (poo, "machado de pedra"). A categoria ainda é utilizada por Adriano, o que me parece uma ressignificação da categoria dos antigos para denominar esse tal "povo da mercadoria", como diria Kopenawa. A passagem de Poowëteri - "povo do machado" - para napë pë (napë thëpë, em yanomam, no plural, pl. pë) - categoria das relações intercomunitárias yanomami, conforme o esquema de Albert apresentado acima - indica a passagem de um povo estranho e desconhecido para um povo agora conhecido e potencialmente aliado. Se napë pë, antes do contato, indicava os inimigos atuais e as pessoas hostis, com a regularidade e estabilização da relação com os Poowëteri passa assim a indicar os potenciais aliados, parceiros, amigos e, com alguma frequência, ainda inimigos. Trata-se de um processo relacional onde essas categorias são negociadas e assim se atualizam de uma forma ou de outra - como aliado ou como inimigo, portanto. No Marauiá, inclusive, uma nova categoria foi criada, num esforço de traduzir e diferenciar os napë "comuns" daqueles "que mandam". São estes os napë patamorewë, indicando algo como os "representantes de Estado", "o governo" ou aqueles "que têm poder e dinheiro".

É através desse caráter dinâmico e relacional que se constitui o atual espaço sociopolítico yanomamí, em particular, na região do Rio Marauiá. Como sugere José A. Kelly Luciani (2005, 2011), a partir de Roy Wagner, as transformações do "espaço convencional Yanomami" no sentido das relações intercomunitárias tradicionais ou "convencionais" e de suas respectivas categorias sociopolíticas (cf. Albert, 1985) apresentam "uma constante dialética entre convenção e inovação" (Luciani, 2011, p. 74). Através dessa dialética, as relações sociopolíticas são constantemente atualizadas, a partir das crescentes relações com os napë e com os napë patamorewë ("o governo") - no que o autor nomeia como "eixo de transformação em branco" -, produzindo "novos conjuntos de relações convencionais" e, sem que um deixe de existir em função do outro, convenção e inovação coexistem e, variando em função do contexto da relação (Luciani, 2011, p. 74).

No começo da década de 1990, já no contexto da regularidade 
dos contatos com os napë e com a crescente implantação dos serviços de saúde, o grupo que atualmente habita o xapono Raita foi o primeiro a derivar do grande Pukima, conhecido atualmente como Pukima Centro, onde todos Pukimapiwëteri moravam juntos. Os motivos da mudança transcenderam a presença missionária e conta-se que foi decorrente de um conflito familiar, como costuma ocorrer (cf. Miranda, 2020, p. 47). Na medida em que um conflito entre famílias, por exemplo, chega a seu limite, isto é, num ponto a partir do qual poderia resultar em atos violentos e agressivos, desestabilizando a coesão e o bem-estar do xapono, um dos grupos decide por sair, fundando o seu próprio xapono em outra localidade. Esse movimento pode ser de súbito, mas normalmente é antecedido pela definição de um novo terreno, a abertura de novas roças e a construção de abrigos temporários ou casas mais provisórias. No caso do Raita, mudaram-se para um local onde já haviam abertos roças e havia muitas batatas nativas conhecidas por rai. Com a mudança, o grupo do Raita aproximou-se um pouco do curso do Marauiá, embora a real implantação do xapono nas margens do rio, separado por um caminho de algumas centenas de metros, só viesse a acontecer numa segunda mudança, do chamado Raita Centro, hetu hami, ao Raita Beira, koro ahami.

Hetu hami indica tudo aquilo que está "acima", como os xapono "na serra" ou "no mato", como costumam dizer em português. O termo, entretanto, possui um sentido complementar uma vez que hetu indica também a claridade do céu, visto através de uma clareira, seja a de um xapono, de uma roça ou em um rio. Diferente da noção de hetu misi, que se refere à camada celeste acima do patamar terreno, ou ao que chamamos de abóbada celeste ou céu num sentido mais geral, hetu refere-se então ao céu entrecortado pela mata ao redor, à clareira não no sentido terreno, mas celeste. Assim, hetu hami quer dizer algo como ir "ao céu", ir "até o céu" ou, simplesmente, "subir", no sentido de "subir em direção ao céu" (Lizot, 2004, p. 80). Koro hami, por sua vez, indica o que está "rio abaixo", como os xapono "de baixo" ou "da beira". Koro também compõe um dos polos da oposição binária e eixo de orientação espacial, koro/ora, algo como "rio abaixo"/"rio acima", embora seu uso vá além dos caminhos fluviais e inclua também os caminhos na mata (peiyo), de modo que o koro indica normalmente a parte do caminho que parte do xapono e ora a parte contrária (Lizot, 2004, p. 174).

Esta oposição entre acima e abaixo, ou montante e jusante, é 
também uma diferenciação relevante nas atuais categorias sociopolíticas da região que claramente divide os grupos do Alto Marauiá e do Baixo Marauiá. A cisão decorre das sucessivas mudanças dos quatro grupos derivados do Hayanae, cada um definindo novas regiões a serem habitadas e também implantação da missão, no médio curso do Marauiá. Assim, esquematicamente, os grupos "de baixo" referem-se aqueles que se aliaram mais aos salesianos, e que habitam da missão à foz (incluindo os afluentes situados nesse intervalo), e os "do alto indicam aqueles que se aliaram menos, deliberadamente recusando a proximidade com o "povo de Deus" (Deusteri, como dizem), e que habitam cabeceiras do Marauiá.

Tratando-se então dos grupos do Alto Marauiá, pouco tempo após a cisão do Raita o xapono Pukima foi parcialmente abandonado e os grupos que lá habitam desceram o rio, aproximando-se das margens do Marauiá. Segundo contam os os atuais përiomi, o movimento decorreu após muita discussão entre os moradores do xapono e destinava-se a atender o pedido de aproximação dos órgãos de saúde. Contam os përiomi que os enfermeiros e técnicos de estavam fartos de caminhar por horas mata adentro, carregando nas costas as pesadas bagagens com equipamentos e medicamentos, mas também, com a aproximação às margens, permitirse-ia ampliar o acesso ao sistema de saúde e ainda agilizar a remoção de pacientes. Foi com esse movimento em direção à beira do Marauiá, motivado pela questão da saúde, que o xapono Pukima passou a ser chamado de Pukima Centro e o novo xapono de Pukima Beira.

Nota-se que através desse movimento rio abaixo - e na medida em que foi se ampliando o acesso aos serviços de saúde e educação, atualmente estadualizados - a onomástica dos grupos e a toponímia dos lugares que estes habitam também passaram por modificações. Além da oposição e dos termos "centro" e "beira", os nomes foram reduzidos, como por exemplo a passagem de Pukimapiwëi para Pukima, para adequar-se ao léxico da burocracia estatal. Além do mais, a própria mudança dos nomes dos grupos locais e das aldeias que, como vimos, era frequente e decorrente da mudança da localidade habitada, tomando para si o nome dado a cada porção da terra-floresta (urihi), tornou-se um empecilho já que, complica a gestão dos postos de saúde e seus respectivos cadastros, fichas, relatórios e coisas do gênero. No entanto, o empecilho não é um impeditivo à mudança, de modo que atualmente, se necessário, mantêmse os nomes, acerta-se com a secretaria de saúde SESAI, mas o xapono 
muda-se, largando postos de saúde e escolas para trás.

Segundo Hipólito, o atual përiomi do Pukima Beira, foi seu pai que se convenceu da importância de uma aproximação do atendimento de saúde durante uma visita ao xapono Bicho-Açu, no Baixo Marauiá, e a partir do diálogo com uma antiga liderança e parente daquele grupo dos antigos Ironasiteri. Ao retornar para o Pukima Centro, explicou para toda a comunidade e decidiram, ao fim, pela mudança. Como sugere Luciani, tais deslocamentos são frequentemente vistos de maneira equívoca, de modo que aquilo que para os yanomami é visto como uma estratégia de resistência e uma perspectiva de um futuro melhor, aos olhos dos napë surge como degeneração e perda da cultura (2011, p. 92). Após essa mudança, manteve-se uma série de idas e vindas entre o Pukima Centro e o Pukima Beira até que em 2008, após um conflito entre famílias, parte do grupo se separou e voltaram para o afluente Pukima, à montante do Marauiá.

O desentendimento deu-se na esteira de uma forte epidemia de malária que assolou o grupo Pukimapiwëi nessa nova localidade. Muitos morreram com esse impacto, apesar do posto de saúde recém instalado, e a epidemia foi ali compreendida como efeito direto da aproximação da margem do Marauiá já que, como dizem, "no tempo que a gente morava na serra não tinha esse mosquito". Parte do grupo resistiu, então, em manterse ali, onde tantos já haviam morrido, marcando negativamente o espaço do xapono, e optaram por voltar às cabeceiras. Como diz Guimarães Rosa, no conto "Sarapalha", de Sagarana, a malária ficou e "quem foi s'embora foram os moradores". Mas, diferente do conto, a outra parte do grupo também ficou e somente em 2016 que mudaram de local, migrando um pouco rio acima. O grupo que saiu e voltou ao Pukima Centro, tempos depois, decidiu por abrir um segundo xapono, o Pukima Cachoeira, bem na cabeceira do Rio Pukima, onde uma grande cachoeira define o ponto final da passagem dos barcos a motor e, assim, mantiveram-se ainda um tanto afastado das margens do Marauiá (como fez o Raita Centro), mas ainda possibilitando o acesso de barcos e transformando a antiga caminhada de cinco horas em uma de poucos minutos. Em 2014, entretanto, o Pukima Cachoeira mudou-se novamente, descendo o rio e, dessa vez, implantando o xapono mais próximo das margens e em 2016 separou também um pequeno grupo, abrindo outra clareira entre o Pukima Cachoeira e o Raita e fundando um outro xapono, o Tomoropiwëi.

Os demais grupos passaram por processos de mudança e cisão 
análogos (e para uma descrição mais completa, cf. Miranda, 2020), de modo que dos Xamatawëteri originaram-se os atuais Ixima, Komixiwë (no mesmo local que a Missão Marauiá) e Água Viva (no Rio Preto, afluente do Padauari); do Pohoroawëteri passou-se ao Pohoroa (equivalente ao "beira" em oposição ao antigo "centro"), Jutaí, Tabuleiro e, mais recentemente, Serrinha; do Ironasiteri, passando por distintos lugares, resultou-se no Bicho-Açu e, recentemente, no Apuí; e os Konapimateri, que diferente dos demais grupos não derivaram do Hayanae, dividiram-se recentemente entre Kona Centro e Kona Cachoeira e somaram-se a outros dois grupos Momohiteri, aparentados e recém migrantes da Venezuela, Manakapiwëi e Xamakorona. Atualmente a população que vive nas margens e afluentes do Marauiá, segundo o censo do Distrito de Saúde Estadual Indígena Yanomami (DSEI-Y) de 2018, consiste em cerca de 2.478 pessoas, representando uma expressiva multiplicação populacional em um século de mudanças e andanças e, especialmente, partindo de um único xapono, o mítico Hayanae.

Conforme as definições clássicas de Albert (1985, p. 211), o atual conjunto dos 17 xapono da região do Rio Marauiá poderia ser configurado como um extenso "conjunto multicomunitário [ensemble multicommunautaire]" de grupos próximos (mas não tão próximos em seus extremos e sim a dias de distância, mesmo que de barco), que habitam uma área geográfica comum (a bacia do Rio Marauiá) e são provenientes de uma mesma comunidade de origem (do Hayanae), além de alguns grupos de origem histórica um pouco distinta mas que atualmente habitam a mesma área e mantêm relações de vizinhança e aliança (os Konapimateri e Momohiteri). Esse extenso "conjunto multicomunitário" compõe-se de parentes consanguíneos e afins conectados por alianças políticas, redes de trocas e casamentos, encontros e diálogo entre os pajés, e convites mútuos às festas funerárias.

Ao mesmo tempo, as relações no interior do extenso conjunto são tensionadas pela distância, ressignificada também pela possibilidade de deslocar-se de barco pelo rio, e pelas novas formas de fazer política, através da Associação Kurikama por exemplo, e também pelas diferentes formas de relação com o Estado ou os salesianos ou organizações diversas, evidenciadas na divisão maior entre Alto e Baixo Marauiá. Nesse contexto de extensão da ideia de "conjunto multicomunitário", onde as relações de vizinhança e aliança são complexificadas e expandidas, o que se nota é 


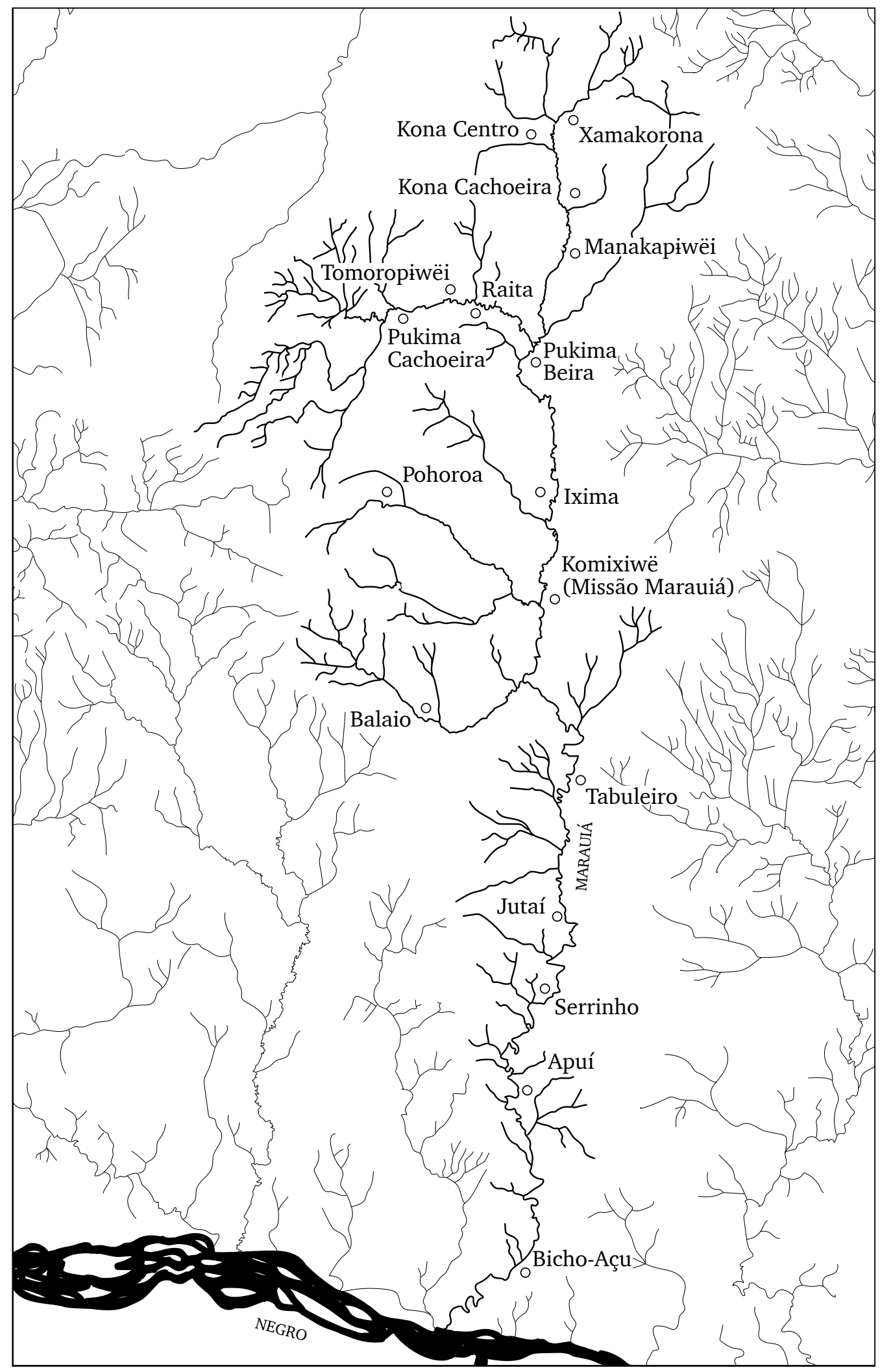

Fig. 09. Mapa com a configuração espacial dos xapono na região do Rio Marauiá em 2020. 
uma maior relação de trocas, visitas e casamentos mútuos no interior de cada grupo de origem derivado do Hayanae (Ironasiteri, Xamatawëteri, Pohoroawëteri e Pukimawëteri) e entre os grupos menores que posteriormente migraram para o Marauiá (Konapimateri e Momohiteri), muito embora nas festas reahu e, sobretudo, no contexto interétnico da Associação Kurikama essa forma seja expandida e atualizada. Cada um desses grupos, como os Pukimawëteri (divididos atualmente entre os grupos do Raita, Pukima Beira, Pukima Cachoeira e Tomoropiwëi) conformam então um yahiterimi, um grupo residencial com privilegiadas relações de afinidade e consanguinidade (Lizot, 1984).

Os grupos residenciais yahiterimi consistem em um conjunto de grupos locais, cada um em uma mesma unidade residencial, os xapono. Cada um dos xapono é econômica e politicamente autônomo e, em termos ideais, visto como unidade endogâmica. No entanto, é comum que haja casamentos exogâmicos e, no caso do Marauiá, inclusive entre diferentes grupos residenciais. Com isso, instaura-se uma grande dinâmica na composição dos grupos locais e é notável o fluxo de rapazes entre os xapono, mudando-se à medida que se casam, se separam e casam-se de novo, seguindo os rumos matrilocais da presente noiva. Como tudo, entretanto, a matrilocalidade não configura uma regra estanque e exceções ao modelo são comuns, seja por razões atuais, como a vinculação do rapaz que pode ser um professor na escola do seu xapono de origem, o que o impede ou complica sua mudança, seja por razões de conflitos diversos no interior de uma família, não exatamente afetadas pela presença do Estado ou algo do tipo. Os casamentos exogâmicos são comuns entre os xapono que foram outrora um mesmo xapono, uma mesma comunidade, como alguém do Pukima Beira casar-se com alguém do Pukima Cachoeira. Assim, costumase casar perto muito embora haja também casamentos fora, ou seja, em aldeias das quais há uma certa distância física ou de parentesco; mas como todos são descendentes do Hayanae sempre há algum parente em comum.

Dessa maneira, embora os xapono sejam autônomos, cada um com seus respectivos përiomi, o Marauiá consiste em uma intrincada malha sociopolítica que extrapola inclusive a bacia do rio e alcança o xapono Água Viva, no Rio Preto, afluente do Padauari, representada atualmente pela Associação Kurikama. Essa malha, além disso, eventualmente sobrepõe-se a outras malhas sociopolíticas, como do Marari ou do Maturacá, conectase via radiofonia, cruza-se com uma série de outras redes políticas ou 
de serviços através dos napë e suas instituições, configurando então um regime complexo de redes de aliança e intercâmbio intercomunitários que, como sintetiza Albert, "liga a totalidade das unidades locais Yanomami de um extremo ao outro de seu território" (1992, p. 3).

Esse extenso processo de fissões e de mudanças expande as redes de aliança e a malha sociopolítica yanomami desde os tempos de Periporiwë, passando pelas grandes migraç̃es do século XVIII e, no caso do Marauiá, com intensas e ininterruptas movimentações desde o começo do século XX. Assim como os conflitos que as originam e as novas alianças que resultam, as diferentes formas de mobilidade não cessam, mas transformam-se e continuam, numa incessante reinvenção das "estratégias de mobilidade" (Nilsson \& Fearnside, 2011) como modo de ocupar e habitar a terrafloresta urihi. As transformações no território compartilham com as transformações míticas essa espécie de conjugação em um pretérito imperfeito. Os movimentos, assim, partem do tempo de Periporiwë, ainda em aberto e inconcluso, atravessam gerações, atualizam-se, transformamse e continuam. Como diria um pajé Parahiteri, "onde aconteceu essa história, outra segue" (Ballester, 2017, p. 33). 


\section{Terra-floresta}

A floresta respira, mas os brancos não percebem.

Davi Kopenawa

(Kopenawa; Albert, 2015, p. 472)

Numa tarde destas, trabalhando na roça de Adriano, përiomi do Pukima Cachoeira, e ajudando uma de suas filhas, Neide (uma dedicada professora na aldeia), a queimar o mato que havíamos cortado, fizemos uma pausa sentados sobre um tronco tombado, com tabaco brotando debaixo de sua sombra e de suas cinzas. Como de costume, papeávamos sobre nossos lugares de origem e suas radicais diferenças. Já que eu era parte do "povo de São Paulo", perguntei a ela como ela se identificaria e ela afirmou, misturando o português com o yanomami: "Eu sou Neide urihiteriyoma", o que poderia ser traduzido por "eu sou Neide mulher (-yoma) do povo (-teri-) da terra-floresta (urihi)". A resposta foi um tanto peculiar, pois antes de se identificar com seu respectivo grupo local, optou por evidenciar o contraste com os brancos e sua "terra-cidade" (napë pë urihi pi) marcando seu vínculo cognático e residencial. "Mulher do povo da terra-floresta", urihiteriyoma.

O sufixo -teri indica uma comunidade, um grupo local ou também um membro destes, ou seja, um morador de determinado lugar (Lizot, 2004, p. 437). Ao se referirem a nós, por exemplo, no cotidiano da aldeia, é comum escutarmos algum chamado pelo "povo de São Paulo". Os grupos locais são assim constituídos por uma parentela onde o 'nós' cognático é idealmente identificado ao 'nós' residencial e assim as pessoas são identificadas pelo seu local de residência atual e, em alguns casos, pelos seus locais de origem. Adriano, por exemplo, se identifica como "Adriano Pukimapiwëteri Yanomami". O primeiro nome é de explícita função pragmática, destinado a se relacionar com os modos de operação do Estado e seus tantos papéis, registros, listas, fichas, certidões e documentos - substituindo, eficazmente, o nome originário yanomami que não pode ser dito. O segundo, então, indica o grupo local ao qual pertence, dos Pukimapiwëteri, "o povo do Pukima”, seguindo a mesma lógica e os mesmos termos da tradução feita por eles. E o terceiro, "Yanomami" é parte do 
idioma de Estado e forma de identificar os indígenas vinculando-os a seu respectivo povo de origem. Não se trata, no entanto, de subserviência. $\mathrm{O}$ idioma do Estado é também canibalizado pelos indígenas e convertido em parte do idioma do movimento indígena, sendo um eficaz procedimento de autodeterminação enquanto um povo específico e organizado.

$E$ É nesse contexto de intensificação da relação com os napë e, especialmente, com formas outras de fazer política, que se evidencia a passagem "de um discurso cosmológico sobre a alteridade a um discurso político sobre a etnicidade" (Albert, 1995, p. 5), notável na passagem de urihiteri pë, "povo da terra-floresta", à identificação como "índios Yanomami", num ambiente político mais amplo ou associado ao movimento indígena. Na floresta, o contraste necessário é outro, como vimos com a breve parábola da roça. Aqui, entretanto, pretendo desdobrar algumas linhas não sobre a questão da etnicidade, mas sobre as noções em torno da ideia de urihi e sua respectiva tradução por "terra-floresta", proposta inicialmente por Davi Kopenawa e Bruce Albert (1995), mas atualmente consolidada inclusive no discurso político das associações yanomami no trato com os napë (os "brancos", "não-indígenas"). Adoto aqui justamente essa tradução, pois ela me parece resolver melhor a abrangência do campo semântico, conceitual e cosmológico da noção de urihi.

Comecemos então falando da terra-floresta, pois é aqui, essencialmente, que os Yanomami penduram suas redes. Para isso, me pautarei pela profícua colaboração e conexão cosmopolítica, intelectual e estética (cf. Cesarino 2014) entre Kopenawa e Albert (2015), mas adicionando mais uma camada e relacionando-as com diálogos meus com Adriano, especialmente aqueles ocorridos durante caminhadas floresta adentro. Tais caminhadas são sempre prazerosas e cansativas, mas, sobretudo, importantes espaços e momentos de aprendizagem. Nelas, Adriano se compraz em nos conduzir pelas trilhas na mata, comentando sobre as antigas rotas e os antigos locais de moradia, sobre espécies diversas da fauna e flora e sobre elementos de sua história vinculada à resistência e a relação com os napë. As histórias são sempre situadas no território, com relatos que conectam cada igarapé, cada serra e cada caminho a alguma passagem de seu passado recente ou de seus antepassados, sobrepondo camadas históricas às folhas e aos seixos da mata e conferindo uma densidade outra a afirmações como "a nossa floresta", kamiyë yama ki urihi pë ou "a minha terra", ipa urihi a. 
É através dessa imbricada malha (reticular e não exatamente concêntrica, como descrito historicamente, cf. Albert \& Le Tourneau 2007) de rios e caminhos, conectando uma verdadeira galáxia de pontos - casas, casas vizinhas, roças ativas, roças abandonadas, locais de acampamento, rotas de caça, locais de coleta e cidades -, que podemos aprender sobre a noção de "nossa floresta" e "minha terra". Nas traduções para o português é comum essa variação entre "terra" como categoria jurídica e "floresta" como formação vegetal. Tais soluções operam drásticas contrações semânticas ao mesmo tempo em que sabiamente se ajustam aos termos da comunicação interétnica (Albert, 1995). "Minha terra" ou "nossa floresta", no entanto, não se referem apenas a um local estático ou burocrático como uma categoria jurídica, mas ao espaço habitado ao longo da história de vida de um determinado grupo ou pessoa. Como sugere Bruce Albert, a partir do momento em que escutamos os habitantes do chamado "território yanomami" (entre o Brasil e a Venezuela, no interflúvio Oricono-Amazonas) ou, no lado brasileiro, da Terra Indígena Yanomami, o aparente espaço achatado da cartografia estatal adquire outras dimensões, desvelando-se, na verdade, uma sociocosmologia com complexas coordenadas onde as relações espaciais são intrinsecamente conectadas às relações temporais, como um macro-cronótopo (a partir de Mikhail Bakhtin; cf. Albert, 2009, p. 147).

Adriano, numa destas conversas, por exemplo, me contava sobre sua ida a uma manifestação do movimento indígena em Manaus, anos atrás, e da fala que fez dirigida aos deputados e ao então vice-governador, junto de outros indígenas "parentes" do Amazonas: “(...) Vocês, governantes, vocês não são meu pai. Meu pai tá aqui [no xapono, na urihi], meu pai tá aqui. Ele é diferente de vocês. Ele mora na floresta. Essa floresta é nossa, nós somos os donos, aqui que eu nasci, aqui que meu pai nasceu". Nesse fragmento, enunciado originalmente em português, podemos notar a variação do sentido de floresta (urihi) para designar a mata e o ambiente ("Ele mora na floresta") e também o território ou o espaço ocupado ("Essa floresta é nossa").

Frente ao enunciado de que "essa floresta é nossa" é importante não se apressar na leitura, conectando-a apenas aos pressupostos do regime euro-americano de posse. Logo, esta é contrastada e complexificada ao dizer que "aqui que eu nasci, aqui que meu pai nasceu". Assim, sinteticamente, a ideia de urihi conjuga as relações temporais e espaciais 
de um determinado grupo e indica o local onde se habita naquele instante, ao mesmo tempo que os espaços e clareiras habitados pelos ancestrais ao longo de sucessivas migrações, dialogando com a proposição do cronótopo de Bruce Albert, embora não mais numa escala macro e sim micro. A referência de Adriano ao seu pai, e ao local onde ele habita, é frequente em suas declarações. Em contextos de assembleias interétnicas, inclusive, é recorrente escutar das lideranças yanomamí, Adriano por exemplo, contraposições ao governo como "vocês [representantes do Estado] não são meu pai!". Nessas afirmativas, para além da resistência dos indígenas a um certo paternalismo estatal, reforçando a autonomia política que insiste em se fazer presente, é também notável a relação com a questão da ancestralidade e do parentesco assentada sobre a floresta, o território, a terra, a Terra e a urihi, simultaneamente.

A passagem da escala global ou macro à escala local ou micro da noção de urihi é evidenciada pela replicação escalar dos grandes movimentos migratórios às redes de caminhos e clareiras abertas na história de um determinado grupo ou indivíduo. Vimos no capítulo anterior ("Sangue da Lua") como isso ocorre especificamente no Rio Marauiá de modo que "a 'terra-floresta' global e a 'terra-floresta' local parecem estar conectadas não só por uma inter-relação semântica, mas também por uma espécie de geometria fractal" (Albert, 2009, p. 155). Em ambas as escalas, entretanto, há em comum a ideia de que é através do movimento ao longo de um caminho de vida que o "povo da terra-floresta", urihiteri pë, produz a urihi. Dessa forma, expressões como "a nossa floresta", kamiyë yama ki urihi pë, ou "a minha terra", ipa urihi, designam a área habitada atualmente, incluindo os caminhos pela mata, as clareiras com roças familiares e a aldeia, sendo o meio do xapono o ponto focal de onde a perspectiva é construída. Mas esse modelo micro é também sobreposto ao modelo macro, passando a indicar também as extensões dos caminhos pelo tempo e, com isso, todos os espaços previamente ocupados na história de migrações desse povo.

Em outras palavras, ser "povo da terra-floresta", urihiteri pë não é estar em um lugar único e fixo, mas ao longo de caminhos -"caminhos de identificação [paths of identification]", diria Albert (2009, p. 156). Dessa forma, como nota Albert, o conceito de urihi contrasta radicalmente com a "visão de mundo ruralista contaminada pela metafísica da autenticidade e 'raiz"' (2009, p. 146). A partir de outros pressupostos e outras relações 
entre territorialidade, temporalidade e identidade, o conceito de urihi se aproxima mais de uma geometria rizomática e dinâmica, constituída de múltiplas camadas de tempo e história: um "território portátil", como define Albert, inspirado em Gilles Deleuze e Felix Guattari, "que pode deslizar sobre o chão da floresta de uma região para a outra" (2009, p. 155-156).

Outro exemplo que estende os sentidos de urihi como esse território (ou categoria, ou conceito) portátil para além da própria floresta é um relato de Kopenawa sobre uma de suas viagens à Europa, a "terra dos antigos brancos", "a terra que eu nomeei eropa urihi a" (Kopenawa; Albert, 2015, p. 396). Nesse contexto, Kopenawa situa a terra estrangeira em um esquema cosmológico associado aos rastros da fuga mítica do demiurgo Omama, no fim do processo de montagem do mundo e da terra-floresta urihi, que resulta na criação dos napë e, ao mesmo tempo, de sua terra, entendida enquanto "terra-espelho" (urihi mirekopë) dos espíritos xapiri (m.q. hekura, na língua yanomamì), uma vez que é dessa região, na direção do sol nascente, que muitos dos espíritos auxiliares dos pajés vêm dançando em seus caminhos de espelho em direção a eles (Kopenawa; Albert, 2015, p. 400). Paris, por exemplo, foi nomeada a Kopenawa pelos espíritos auxiliares que o guiavam, enquanto "kahëhei urihi, a terra que treme" (Kopenawa \& Albert 2015, p. 422). Segundo o pajé, desde o momento em que ali pisou, sentiu-se cambaleante, como se estivesse "de pé numa canoa no meio do rio!" e, preocupado, perguntavase se aquela terra estranha não o faria, de fato, virar outro (në aipë). A explicação é situada no esquema cosmológico yanomami, de modo que a terra do sol nascente, eropa urihi $a$, se localiza nas bordas da camada terrestre, enquanto a yanomae thë pë urihipë, a "terra-floresta dos seres humanos", se encontra no centro, no coração da terra. Apesar da distância e das diferenças radicais, o conceito de urihi pressupõe sua outra face além-mar, nas bordas da terra, multiplicando seus sentidos e situando a estranha terra que treme num mesmo esquema cosmológico, pois como disse Kopenawa, "trata-se da mesma e única terra" (2015, p. 396), urihi pata, "o mundo todo".

Emaranhada nessa malha socioespacial, a dimensão mítica e cosmológica do conceito de urihi, tal qual a manipulada por Kopenawa, é fundamental para nos aproximarmos de outras camadas de significação do conceito e também daquilo que excede os limites tradutórios e ontológicos, 
no sentido dado por Marisol de la Cadena (2015), da conjugação feita entre terra e floresta, "terra-floresta". Esses limites podem assim ser entendidos como os contornos da diferença radical, que emergem a partir de equívocos entre sujeitos de diferentes perspectivas (cf. Viveiros de Castro, 2004), de modo que o excesso, ou aquilo que excede, é precisamente o que está além do limite, sendo esse, por sua vez, ontológico (cf. De la Cadena, 2015, p. 275). Trocando em miúdos, é numa formulação como a que abrimos este capítulo, "a floresta respira, mas os brancos não percebem" (Kopenawa; Albert, 2015, p. 472), que parte das perspectivas cosmológicas e xamânicas yanomami, que os limites de nossas categorias são excedidos e tornam-se ainda mais visíveis, nesse caso, como as noções em torno de floresta, mas também de respirar e perceber.

No início dos tempos, segundo as narrativas míticas yanomami, o céu caiu sobre a terra. Neste período primordial, o céu ainda era novo e muito frágil, não havia a noite e os dias não terminavam nunca. Com esse evento cataclísmico, uma nova composição dos planos cósmicos que estruturam o universo foi gerada e tornou-se o presente estado do cosmos yanomami, construído e reconstruído pelo demiurgo Omama (ou Omawë, entre os Yanomami) - um "artista", de acordo com Kopenawa (Gomes; Kopenawa, 2015, p. 150). De uma perspectiva vertical, a cosmologia yanomami (sobretudo através das formulações dos Yanomam, mediadas por Bruce Albert) organiza o universo em quatro níveis superpostos, cercados de um grande vazio. O nível superior é entendido como um céu novo, ainda em gestação e de natureza embrionária. Este jovem céu destina-se a substituir a camada celeste abaixo, após a sua queda em uma eventual catástrofe cósmica. Esta camada abaixo é entendida como algo próximo do que chamamos de abóbada celeste, no entanto, possuindo duas faces, do ponto de vista de quem a observa da camada terrena: a superior e não visível, entendida como as costas do céu, e a inferior e visível, tida como o peito do céu. Deste modo, com a queda dessa camada celeste, as outras camadas do cosmos também descendem um nível abaixo. Logo, o céu jovem passa à condição e ao patamar de céu atual originando, em seguida, um novo céu embrionário -, o antigo céu passa a ocupar a camada terrena, e a antiga camada terrena passa ao último nível, o inframundo (cf. Kopenawa; Albert, 2015; Albert, 2009).

Com a queda do céu, nos tempos primevos, todas as montanhas e florestas que compunham a antiga camada terrena, junto de seus 
habitantes ancestrais, foram arremessados para o mundo subterrâneo e somente alguns sobreviventes conseguiram retornar à terra, isto é, às costas do antigo céu. Os sobreviventes, a gente que saiu do céu, conseguiram escapar através de um buraco na atual camada terrena, aberto com a ajuda de mordiscadas de um papagaio mítico. A camada terrena ou o que chamaríamos de terra, por sua vez, é chamada tanto de hutukara, traduzida recentemente por Kopenawa como "antigo céu", "terra", "mundo", "universo", "barriga da nossa terra mãe", "um corpo que é unido e não pode ficar separado", "uma grande casa e estamos dentro do corpo dela" (Gomes \& Kopenawa, 2015), quanto de urihi a pree ou urihi pata, e traduzido outrora por Kopenawa como "a grande terra-floresta" ou "o mundo todo" (Albert, 2009). Nesse sentido, urihi, "terra-floresta", compartilha com hutukara, "o antigo céu", o sentido de patamar terrestre, de terra, ao mesmo tempo em que expressa também o sentido daquilo que está sobre o mesmo, a floresta, "o cabelo da terra, da hutukara", diria Kopenawa (Gomes; Kopenawa, 2015, p. 150). O ponto central, no entanto, é que assim como o cosmos, cujo colapso dos tempos ancestrais pode ocorrer mais uma vez a qualquer momento, e como os urihiteri pë, o "povo da terra-floresta", que segue traçando trilhas nas matas da vida, a terra-floresta não é inerte e tampouco meramente possuível, dominável ou silenciável.

Como nos contam os pajés, mediadores da terra-floresta e do cosmos yanomami, a floresta é viva e respira. Contam os pajés que durante a noite emana do solo úmido seu "sopro de vida" (wahari a), o "sopro vital da floresta" (urihi wixia), que vem da escuridão do mundo de baixo. E de dia, sob o sol quente, retorna para o chão pelos poros da pele da floresta, cujas costas, que correspondem às costas do antigo céu hutukara, estão devidamente vestidas de folhas e protegidas pelas árvores. É essa pele vegetal, feita de flores e folhas caídas, que dá à terra-floresta o que os Yanomam chamam de në rope, seu valor de fertilidade, atributo vital e provedor de umidade, abundância, alimento, perfume e beleza, como um "orvalho fresco [...], líquido como o esperma [que] emprenha as árvores [e] as faz crescer e florescer" (Kopenawa; Albert, 2015, p. 471). É a dança da "imagem do valor da fertilidade në roperi" (Kopenawa; Albert, 2015, p. 475) e os movimentos de toda uma infinidade de seres-imagem da floresta que a torna viva, durável e renovável com um sopro de vida (urihi wixia) longo em oposição ao sopro breve e efêmero dos humanos. 
Fig. 10. "Sou o espírito feminino Parahorioma, circundada por sopros de vento. O perfume das árvores roko ahi se espalha por toda parte rio abaixo, suas flores cobrem o chão. Nossa floresta dos xapiripë é toda adornada por magníficas flores azul-claras" (Iramari Yanomami; Machado, 2014, p. 33). Desenho de Joseca Mokahesi Poroaunahiki thëri Yanomami (2014).

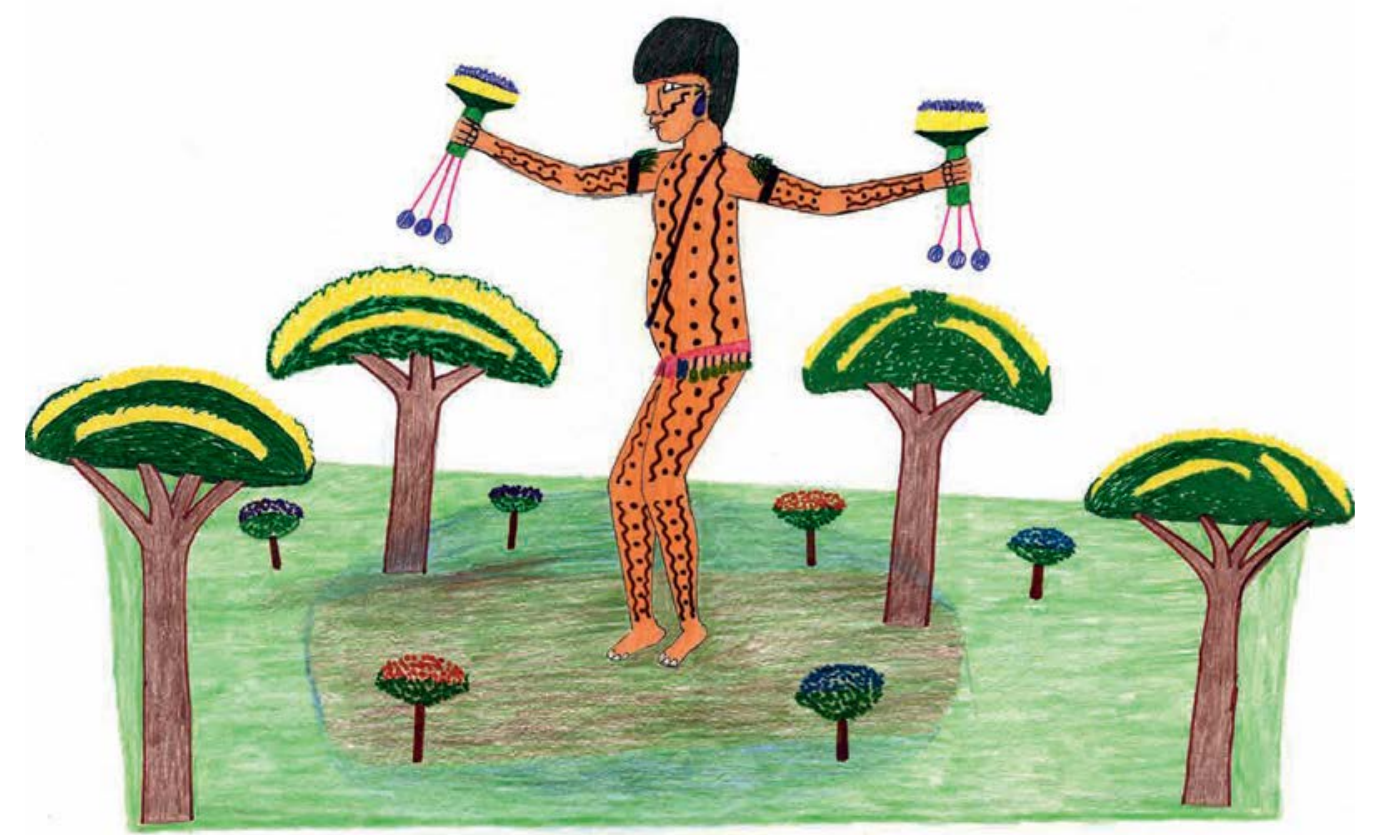


É o que diz Kopenawa: "O que eles chamam de natureza é, na nossa língua antiga, urihi $a$, a terra-floresta, e também sua imagem, visível apenas para os xamãs, que nomeamos Urihinari, o espírito da floresta. É graças a ela que as árvores estão vivas" (2015, p. 475). A correspondência entre "natureza" e "urihi", no entanto, implica num tensionamento radical dos limites da nossa própria categoria de natureza, pois antes de ser um recurso inerte, a terra-floresta é constituída e povoada por uma complexa multiplicidade de seres-imagem, como Urihinari. A noção de imagem utupë em yanomam e no uhutipi em yanomami -, assim, é literalmente vital para aprendermos sobre o conceito de urihi. E para além das camadas socioespaciais, cosmológicas e míticas, é através dela que transparece um outro excesso ontológico importante para essa reflexão.

A tradução de no uhutipi por "imagem" é a solução que aparenta ser mais precisa, de acordo com os meus interlocutores do Alto Marauiá, diferente de outras possibilidades, como "alma", "duplo" ou "espírito". "Imagem", aqui, pode ser compreendida como um dos componentes da pessoa e de tudo que existe no cosmos e na terra-floresta, potencialmente colocadas em diálogo através de seus respectivos seres-imagem - estes sim frequentemente traduzidos por "espíritos", quando a referência é feita de forma genérica. Esse componente (no uhutipi) configura-se como uma indexação de afetos essenciais e indiciais do tempo das origens, o tempo mítico da indiferenciação entre humanos e animais. "Imagem", portanto, é aquilo que compõe e que antecede a configuração enquanto pessoa, coisa ou "espírito" - e talvez por isso a preferência do termo "imagem" para traduzir no uhutipi, diferenciando de "espírito", por exemplo, e reservando essa tradução para os seres-imagem hekura. No uhutipi, assim, trata de imagens não-icônicas, e também não-visíveis para os nãopajés. Como pensa Viveiros de Castro, se "o que define uma 'imagem' é sua visibilidade eminente", aqui as imagens no uhutipi (ou utupë) "são imagens interiores, 'moldes internos', inacessíveis ao exercício empírico da visão" ou "imagens que seriam então como a condição daquilo que são imagem" (2006, p. 325). Logo, não se trata de imagem como representação, tal como compreende o pensamento ocidental, mas como imagem-duplo. As imagens, nesse contexto, são como "representantes que não são representações"; em outras palavras, os seres-imagem "não se parecem com os animais, mas, no contexto mítico-xamânico, os animais se parecem com eles" (Viveiros de Castro, 2016, p. 325). 
Os seres-imagens correspondem aos hekura ou xapiri (em yanomam), normalmente traduzidos pelos meus interlocutores do Marauiá por "espíritos" ou, também, por "pajés". Dizem os pajés do Alto Marauiá que os hekura "são gente", "como os pajés", "mas muito bonitos, muito enfeitados" e "brilhantes". Kopenawa, por sua vez, os descreve como seres humanoides minúsculos e extremamente ornamentados, brilhantes, luminosos e coloridos, que os pajés tornados espírito podem "chamar", "fazer descer" e "fazer dançar" enquanto espíritos auxiliares (2015, p. 610, nota 3). A tradução por "espírito", nota-se, é imprecisa e provisória, pois como diz o próprio Kopenawa, "vocês os chamam 'espíritos', mas [eles] são outros" (2015, p. 111). Estes são classificados geralmente com o sufixo -riwë (ou -ri em yanomam) que identifica os "espíritos" a partir da indexação dos "afetos característicos daquilo de que são a imagem sem, por isso, parecerem com aquilo de que são a imagem: são índices, não ícones" (Viveiros de Castro, 2006, p. 325). Dessa forma, o sufixo denota a intrínseca intensidade, exemplaridade, multiplicidade, hiper e extra-humanidade, imortalidade, invisibilidade (aos olhos de um não-pajé) e alteridade dos seres-imagem em relação ao seres meramente existentes (e visíveis por qualquer um). Como frariwë, por exemplo, onde ira refere-se ao animal, atual, a onça, e -riwë indica seu respectivo serimagem (hekura), mítico e xamânico, do tempo anterior a distinção entre humanos e animais, colocado em diálogo e posto para dançar e cantar pelos pajés (hekura) e traduzido aqui como Onça (com maiúscula). Como dizem no Marauiá, frariwë "é tipo a onça, mas é gente, é pajé grande".

Contudo, o termo hekura, assim como as diversas classes de espíritos assinaladas pelo sufixo -riwë, antes de ser entendido como um substantivo ou um nome singular, designando um ser-imagem em específico, deve ser compreendido através de seu aspecto intrinsecamente múltiplo e intenso. Hekura, nesse sentido, indica a forma pela qual um coletivo (e não um indivíduo) se constitui enquanto seres-imagem, no plural. Assim, quando me refiro aos hekura (eximindo-me de incluir a marca do plural

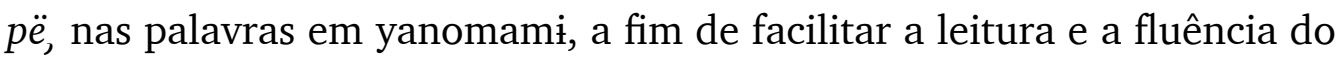
texto em português) ou a uma classe (e não um indivíduo, novamente) específica de hekura, como frariwë (Onça), muito embora a referência seja feita no singular, é de uma multiplicidade intensiva que se trata: "O nome próprio é a apreensão instantânea de uma multiplicidade. O nome próprio é o sujeito de um puro infinitivo compreendido como tal num 
Fig. 11. Ninhos de japim pendurados no ser-imagem da árvore jatobá. Desenho de Joseca Mokahesi Poroaunahiki thëri Yanomami (2013).

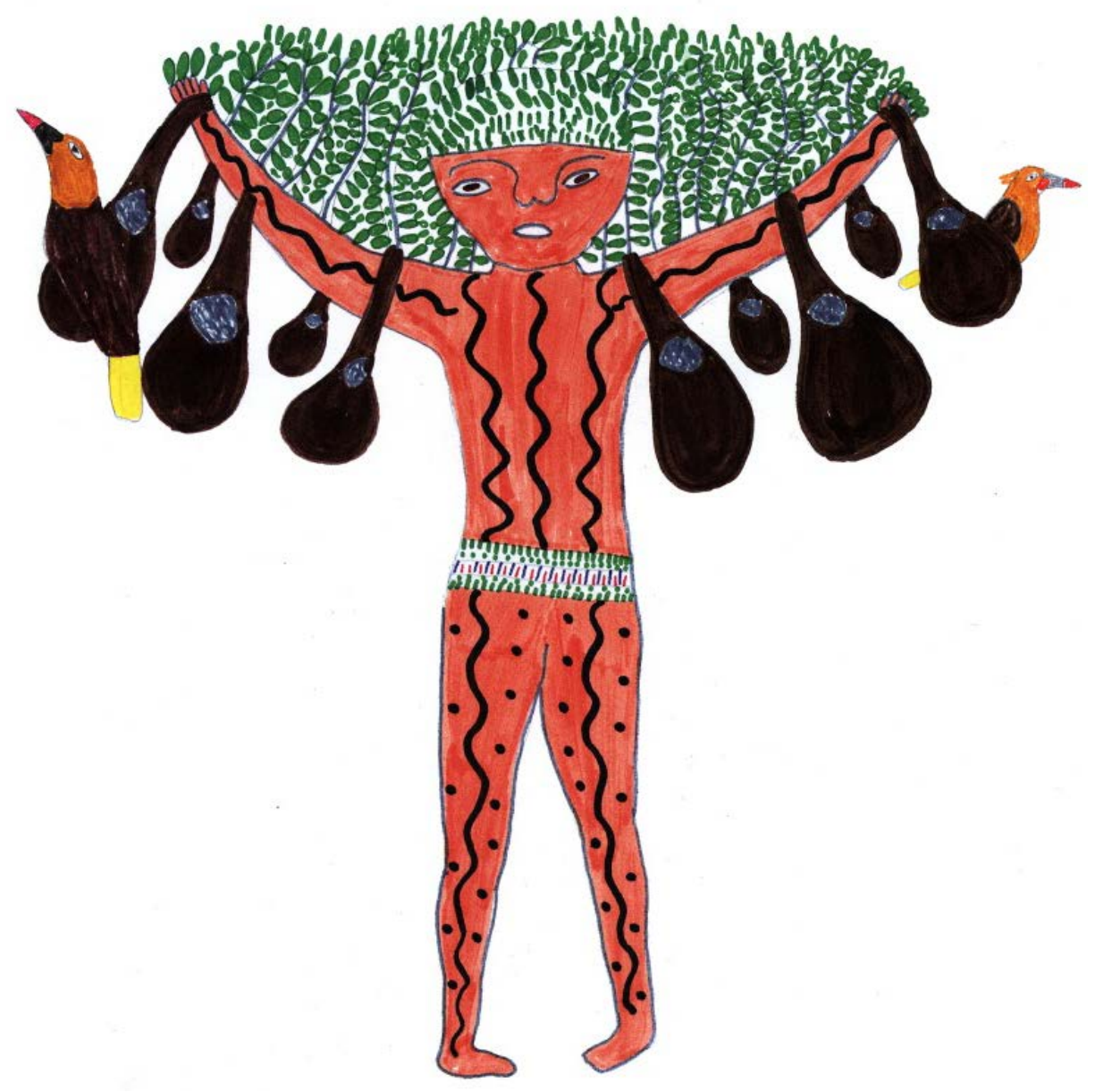


campo de intensidade" (Deleuze; Guattari, 1995, p. 49). Nesse sentido, não se poderia compreender a Onça resumida ao dualismo um/múltiplo, mas, como apontam Deleuze e Guattari:

Seria preciso fazer o inverso, seria preciso compreender em intensidade: o Lobo [ou, a Onça] é a matilha, quer dizer, a multiplicidade apreendida como tal em um instante, por sua aproximação e seu distanciamento de zero - distâncias sempre indecomponíveis (1995, p. 43).

Os pajés compartilham com os ditos espíritos o mesmo termo hekura (ou xapiri em yanomam), de modo que são também eles próprios considerados como "espíritos", no sentido de que ao morrer suas imagens permanecem como aptas a serem atualizadas e postas em diálogo por futuros pajés, especialmente no caso dos pata hekura, isto é, os grandes pajés. Assim, são os pajés enquanto "ser múltiplo, uma micropopulação de agências xamânicas abrigada em um corpo" (Rodgers apud. Viveiros de Castro, 2006, p. 322), que nos revelam o universo dos múltiplos seres-imagem da floresta, essa outra "população de afetos moleculares" (Viveiros de Castro, 2006, p. 321), e aquilo que os brancos não veem, como nos lembra Kopenawa (ele próprio um reconhecido pajé yanomam).

Dentre esses poderosos seres-imagem que descem ou dançam com os pajés, estão Urihinari (o ser-imagem da floresta), Në roperi (o serimagem do valor de fertilidade da floresta) e também "as inumeráveis imagens das árvores, as das folhas que são seus cabelos e as dos cipós", assim como "as dos animais e dos peixes, das abelhas, dos jabutis, dos lagartos, das minhocas e até mesmo as dos grandes caracóis" (Kopenawa; Albert 2015, p. 475). Esta multidão infinita de seres-imagem, segundo Kopenawa, são os verdadeiros "donos" e fontes vitais da terra-floresta urihi: "Os brancos acham bonita a natureza que veem, sem saber por quê. Nós, ao contrário, sabemos que a verdadeira natureza é tanto a floresta como as multidões de xapiri seus habitantes" (2015, p. 476). Não à toa, a necessidade de se contrapor às investidas dos seres "comedores de terrafloresta" (urihi wapopë). São estes que deixam "rastros ruins" na floresta e que, diz Kopenawa, "não se preocupam em nada que suas árvores sejam trocadas por capim e seus rios por córregos lamacentos! Com certeza devem pensar que tanto faz, mais tarde poderão cobrir seu solo com o cimento de suas cidades!" (2015, p. 469).

Os temas "ecológicos" no discurso de Kopenawa (e também de Adriano, como veremos a seguir) constituem uma poderosa "crítica xamânica da economia política da natureza" (Albert, 1995) e expandem 
ainda mais a extensão do conceito de urihi. Para Kopenawa e para os Yanomami, "proteger a floresta" (urihi noamãi) implica numa outra forma de ver, ouvir, pensar e conhecer a floresta. Os pajés veem e dançam com os espíritos da floresta. Os brancos veem os seus desenhos de escrita, leem suas peles de papel. Para os brancos, a floresta é do governo; para os Yanomami a floresta é dos xapiri. Nesse contexto, não é cabível pensar a terra-floresta "como se" fosse mero "meio ambiente" - tomando aqui o sentido de "como se" como um "fingimento heurístico" no qual conceitos ocidentais são utilizados para traduzir "costumes nativos", segundo a provocação feita há tempos por Roy Wagner (2010, p. 238). "Meio", como diz Kopenawa, é tudo aquilo que a terra-floresta não é. Na verdade, para o pajé, "meio" (de "meio ambiente") é "o que resta de tudo o que eles destruíram até agora" (Kopenawa; Albert, 2015, p. 484). A terra-floresta é um mundo por inteiro. Uma multidão de seres, incluindo os infinitos seres-imagem: "Na floresta, a ecologia somos nós, os humanos. Mas são também, tanto quanto nós, os xapiri, os animais, as árvores, os rios, os peixes, o céu, a chuva, o vento e o sol!" (Kopenawa; Albert, 2015, p. 480).

Numa de nossas idas para o mato com Adriano e suas filhas, subindo e descendo as serras ao redor do Pukima Cachoeira, fizemos uma pausa e antes de tomarmos o caminho de volta, sentados num barranco na beira do igarapé, o përiomi nos contou de uma ocasião em que conversou diretamente com um "fazendeiro", "um garimpeiro", "um político" ou um tipo qualquer "que destrói a floresta" em Boa Vista, como fez questão de desdenhar. No diálogo, ao falar dos componentes da urihi, como as montanhas, os ventos e as tempestades, bem como de seus respectivos seres-imagem, transparecem os excessos ontológicos e os limites tradutórios associados ao conceito de urihi, numa potente variação da "crítica xamânica da economia política da natureza" (Albert, 1995). Assim contou Adriano:

Daí eu perguntei para ele, bem na cara dele, "você sabe por que vocês morrem?". E ele disse que "não". E eu respondi: "vocês morrem porque vocês destroem e desmatam as montanhas na floresta, lá são casas de pajés, casas de espíritos perigosos. Eles ficam furiosos com isso, por isso vocês morrem muitos e de súbito. As montanhas são casas de pajés [espíritos hekura] perigosos. Se continuarem destruindo tudo", eu disse a ele, "os pajés vão ficar muito bravos e vão cortar o céu. Eles sabem onde estão os buracos, eles sabem cortar o céu, e se isso acontecer, esse céu vai 

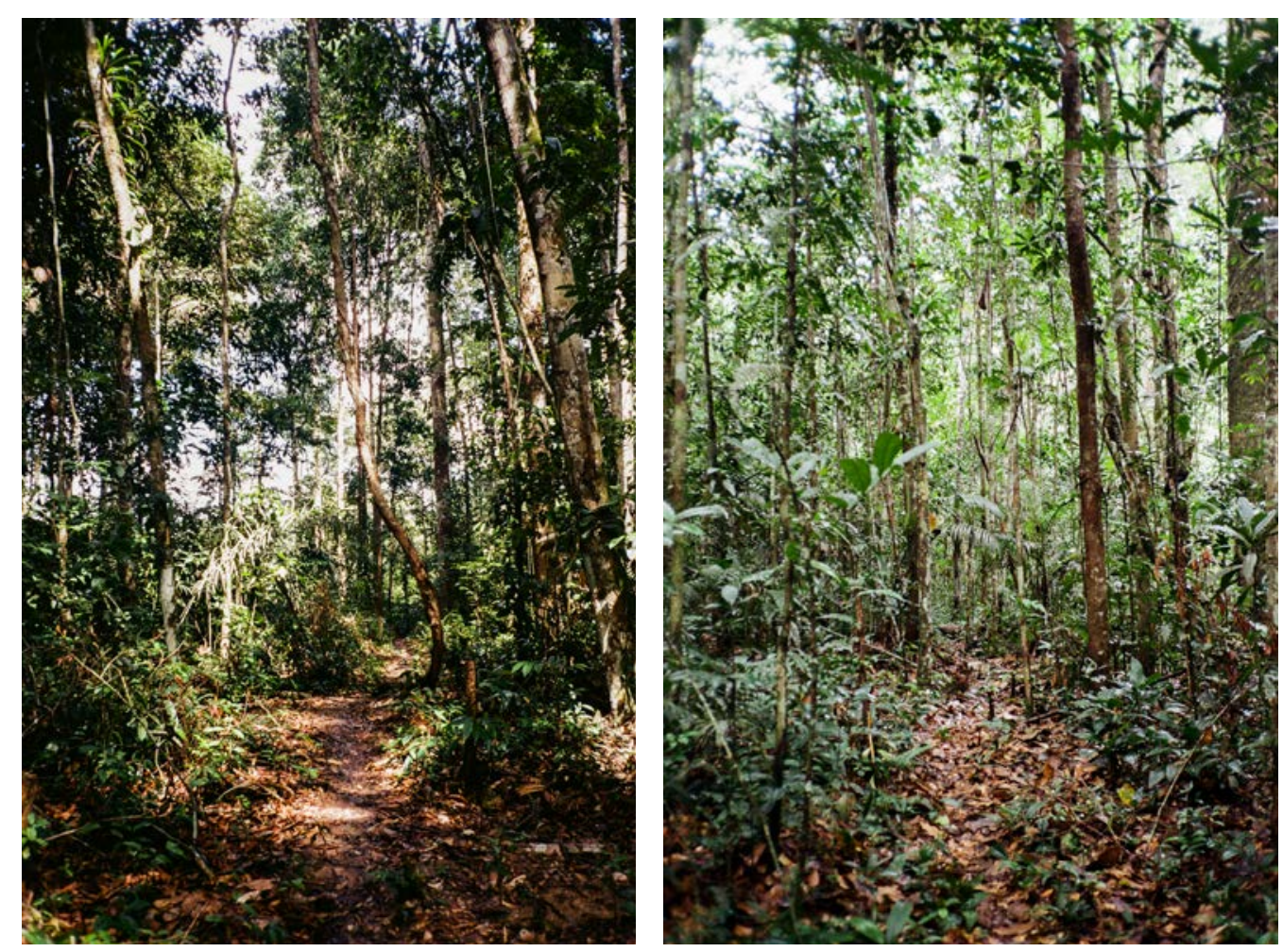

Fig. 12. Caminhos pela terra-floresta (urihi), próximo ao xapono Pukima Cachoeira (2020). 
cair, assim como esse aqui [apontando para o chão, para a terra] que já caiu antigamente. Abaixo daqui tem outros Yanomami e quando aquele céu cair todos vão morrer".

O tema da mortalidade, enunciado de súbito e certamente causando uma desorientação ao tipo que "destrói a floresta", não é “à toa", como diria o próprio Adriano. Em oposição à imortalidade dos seres-imagem hekura, traduzido com precisão por Adriano como "pajé" (evocando a mesma indistinção que é feita na língua e no pensamento yanomami entre espírito e pajé, hekura), os "comedores de terra-floresta" estão também sujeitos aos efeitos incontroláveis e porventura fatais decorrentes da destruição da urihi. Especificamente, Adriano refere-se à destruição das montanhas (pei maki) habitadas por "pajés" (hekura) perigosos e colocadas no solo em tempos ancestrais pelo demiurgo Omawë (ou Omama, em Yanomam). E assim como a urihi é composta dessa "trama de coordenadas sociais e de intercâmbios cosmológicos" (Albert, 1995, p. 10), os potenciais efeitos de sua destruição são também mediados por toda essa multiplicidade de seres e agências xamânicas que a compõe - os "pajés perigosos", como evoca Adriano.

A agência desses "pajés" é assim marcada por uma espécie de relação farmacológica, na qual, tal como sugere Isabelle Stengers, não se resume a um sentido único ou estático mas a uma instabilidade que, a depender da dosagem, podem se dar como remédio ou como veneno (cf. 2011, p. 307). Nesse sentido, trata-se de uma relação nem boa nem má, mas potencialmente perigosa e que implica assim numa constante negociação, numa forma de encontrar um equilíbrio. Em outras palavras, trata-se de uma relação cuja instabilidade é implícita às formas de mediação com os "pajés", na qual as formas de engajamento envolvem tanto as ações voltadas à cura, como o tratamento de uma aparente doença causada por um feitiço, quanto também às diferentes formas de agressão, como o próprio endereçamento de um feitiço. O "perigo" que Adriano associa aos "pajés", portanto, é intrínseco à agência potencial desses seres. E, no que diz respeito à destruição da urihi (a "terra-floresta" que é também sua morada), uma vez que esta seja definitivamente desequilibrada, isto é, completamente destruída, estes vão se enfurecer, "vão cortar o céu" e, enfim, "todos vão morrer".

No entanto, seguindo a lógica de Stengers ao pensar a "intrusão de Gaia" (a partir da teoria de Gaia formulada por James Lovelock e 
Lynn Margulies na década de 1970), não se trata de uma desforra da urihi (a "terra-floresta") e de seus múltiplos agentes (os "pajés", hekura), pois isso seria como mobilizar um tipo de psicologia e atribuir-lhe uma intencionalidade e responsabilidade equívoca e inapropriada. Não se trata, portanto, de evitar a morte lutando contra os "pajés perigosos", assim como não faz sentido, segundo Stengers, "falar de uma luta contra o aquecimento global", mas o importante é lutar contra o que provocou os "pajés", assim como com "o que provocou Gaia, não contra sua resposta" (2015, p. 40, nota 2). O ponto, diria a filósofa, é "ter cuidado" para "não abusar de sua tolerância" (Stengers, 2015, p. 39). E como me disse Adriano, naquele mesmo igarapé, para que o céu não caia (isto é, para que não seja cortado e com isso feito cair) é importante "saber dialogar com os hekura", coisa que os pajés yanomami se empenham, cotidianamente, em fazer. "Ter cuidado", assim, equivale à saber ouvir e falar com, isto é, em "saber dialogar com os hekura", e não contra. Dessa maneira, o que se busca é justamente um equilíbrio, através da mediação dos pajés, dentro dessa relação com a urihi que é por si instável e potencialmente perigosa. O alerta de Adriano, então, indica que uma vez que a destruição da urihi for completa não restarão mais os pajés para dialogarem com os hekura perigosos e, com eles, fazerem essa negociação e assim segurar o céu. Sem eles, "esse céu vai cair".

Os "cientistas e pesquisadores", disse o përiomi numa outra ocasião, devem também aprender a ouvir também os pajés yanomami, pois são eles quem de fato conhecem os "lugares de perigo" que os ousados napë insistem em pisar e deixar seus rastros de destruição:

Tem hekura que mora na Lua, lá é casa deles, casa de espíritos; os brancos vão até lá, pisam nela, mas não sabem disso; assim como tem hekura em outros lugares do universo, como tem casa de espíritos nas árvores altas da floresta e nas cachoeiras; por isso que ir para esses lugares, subir nessas árvores, subir nas montanhas, é perigoso; por isso o conhecimento dos hekura [os pajés] de que esses são lugares perigosos, lugares de perigo; são eles que sabem da origem do mundo, como tudo se formou.

Do contrário, se as suas casas forem destruídas - tanto as casas-montanha quanto as casas-aldeia na floresta - cessam as possibilidade de diálogo e o perigo em potencial abre passagem para o perigo real. Assim, se antes a relação era instável, a partir da impossibilidade de negociação com os hekura, feita pelos pajés do "povo da floresta" (urihiteri), esta cede lugar 


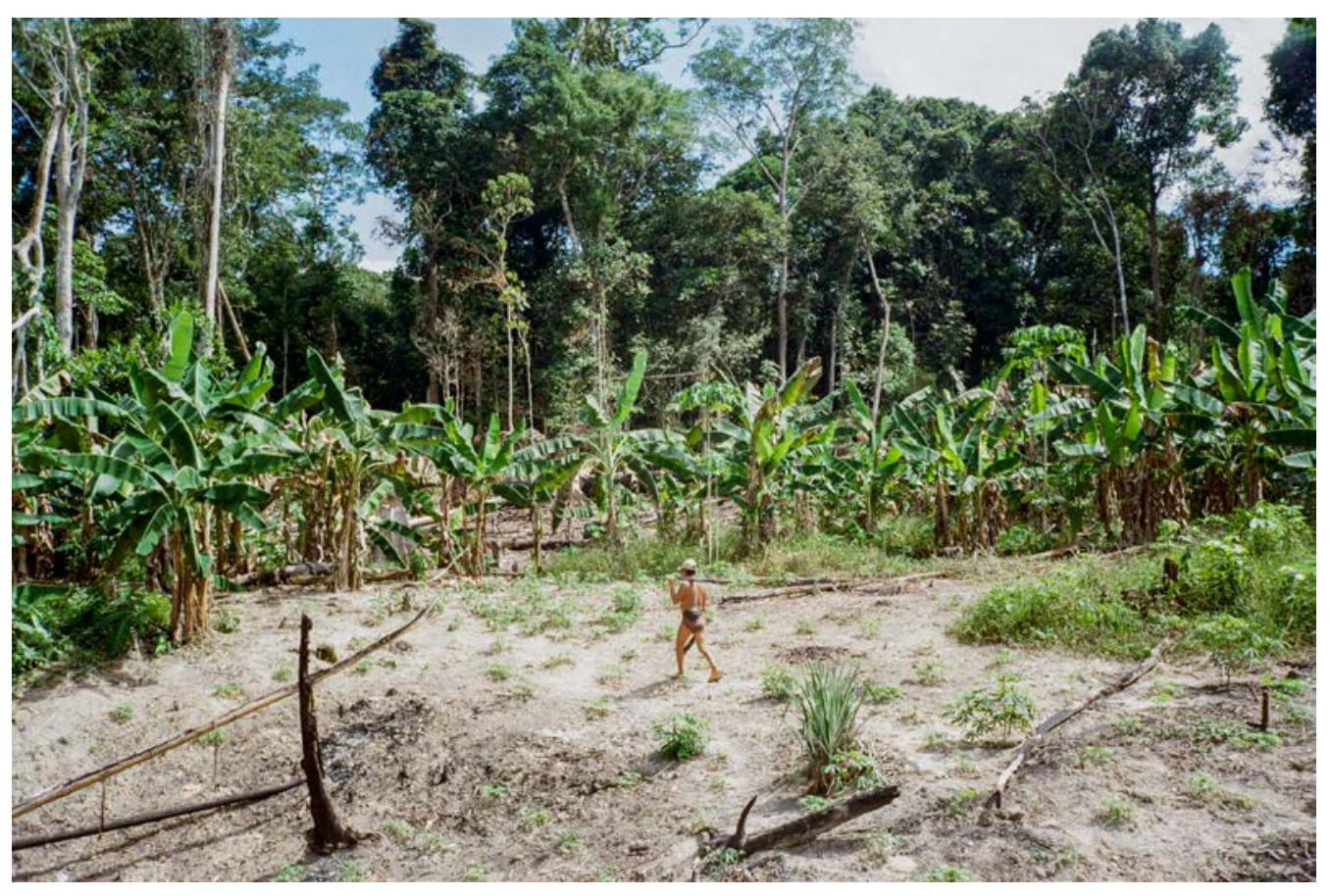

Fig. 13. Caminhando através de uma roça de bananeiras com Adriano, prestes a adentrar a floresta, próximo do Pukima Cachoeira (2019). 
a uma agência unívoca; e catastrófica.

Retomando o diálogo no mato, Adriano seguiu com a história do encontro em Boa Vista, reforçando o alerta ao tipo "comedor de terrafloresta" e evidenciando mais efeitos da potência dos pajés:

E você sabe o que é esse vento? São os pajés [espíritos hekura] brincando. As tempestades são a morte dos pajés. Você sabe por que os aviões caem? Eles caem porque tem muitos espíritos no céu e eles ficam bravos, furiosos com o barulho e a sujeira dos aviões. Os napë não sabem disso, eles não veem, eles só veem dinheiro. Os carros, os barcos, tudo isso tem espírito, é Siparariwë. Ele destrói as coisas mais duras. Se vocês continuarem destruindo tudo, é isso que vai acontecer. São os pajés que seguram o céu e não deixam os outros pajés [espíritos hekura] de lá cortarem, mas se vocês continuarem destruindo tudo os pajés vão ficar muito bravos e o céu vai cair'. Foi assim que eu disse para ele.

"Tudo tem espírito", é o que diz Adriano e o que sempre dizem os Yanomami. Ventos e tempestades, mas também os carros e os barcos. Siparariwë, como explicam os pajés, é o ser-imagem do metal, um poderoso hekura que os pajés "chamam" e "fazem dançar" para lidar com as coisas e com as doenças causadas pelos brancos. Como indica Pedro Cesarino, falando de Shoma Wetsa, ser associado ao "duplo do ferro" entre os Marubo (falantes de língua Pano da Amazônia ocidental), para além da sua importância na fabricação e montagem do cosmos - servindo aos pajés "pra fazer tudo, para fazer lancha, para fazer ferro" - este é também uma "figura de pensamento através da qual a mitopoese se presta a retraduzir as coisas dos brancos" (2013, p. 163-164). Um procedimento análogo poderia ser pensado a partir de Siparariwë. Sipara, em yanomami, é como se nomeiam os terçados adquiridos a partir do contato com os napë e, num sentido mais geral, é um termo usado também para indicar variados tipos de metal. Segundo Jacques Lizot, Siparariwë corresponde também ao nome dado à piranha-preta (Serrasalmus rhombeus), considerada a maior e mais agressiva das piranhas, com dentes muito afiados e apetite insaciável, o que corresponde, de certa maneira, à potência do pajé Siparariwë que, re-traduzido, é capaz de destruir as coisas mais duras e "esquartejar" as doenças xawara advindas dos napë (Lizot, 2004, p. 368). Siparariwë, então, possui essa capacidade de destruição equivalente à dureza de sua imagem e de seus duplos atualizados na terra, como os carros e barcos, feitos de metal. 
Mas é a falta de cuidado dos napë, no seu sentido mais devastador e destrutivo, que coloca a estabilidade do cosmos e toda a terra-floresta em perigo. Se os brancos continuarem deste jeito, não sabendo dialogar com os pajés perigosos, insistindo em destruir suas moradas, lhes perturbando com sua sujeira e sua fumaça na terra e nos céus, não haverá outra saída que não a queda do céu. Como Adriano alerta, trata-se de um problema de ponto de vista e, portanto, de conhecimento ou da falta dele: "Os napë não sabem disso, eles não veem, eles só veem dinheiro". 



\section{Tapiri}

Hõrõnami estaba em la selva. Como amenazaba lluvia,
recogió hojas, amarro um palo entre dos árboles,
apoyó las hojas sobre el palo y se abrigo debajo.

Fragmento de mito narrado por interlocutor Karohiteri

(Lizot et al., 1993, p. 63)

Dizem os pajés Parahiteri que foi Horonami quem ensinou os Yanomami a morar na floresta. Horonami foi um grande pajé e conta-se que, nos tempos primeiros, ele "surgiu dele mesmo; surgiu ao mesmo tempo que esta floresta e foi quem ensinou os Yanomami a morar nela" (Ballester, 2017b, p. 25). Junto de seu cunhado, passavam longos períodos longe do xapono e morando na floresta. E foi assim que "ensinou os descendentes como ir de wayumi" (Ballester, 2017b, p. 26). "Ir de wayumi" ou "sair de wayumi" (wayumi huu), como costuma-se dizer, indica a prática de sair da morada principal, o xapono, e ir viver no mato, em acampamentos yãno, onde o grupo familiar e eventualmente todo o grupo local passa a habitar temporariamente. Nesse capítulo trataremos especificamente dessa forma de habitar a terra-floresta, partindo de uma reflexão sobre a prática do wayumi - o "sair para o mato" - e, na sequência, de uma descrição detalhada do yãno - o "morar no mato", como dizem no Marauiá.

O motivo mais comum para "sair de wayumi" talvez seja o esgotamento dos alimentos nas roças e o aproveitamento das épocas de colheita de abundantes frutos da floresta, como o açaí, a bacaba, o patauá, o buriti e castanhas. Nesse contexto, "sair de wayumï" equivale à uma expedição coletiva onde os grupos se afastam de suas roças e passam a viver integralmente da caça e da coleta na floresta. Horonami, por sua vez, ao ensinar "como ir de wayumï", transmitiu também o conhecimento necessário para essas atividades essenciais:

O pajé Horonami foi quem procurou e descobriu nossa comida, nosso conhecimento da floresta e o habitat dos animais, para que, quando os Yanomami ocupassem a floresta, eles fossem capazes de aplacar 
sua fome de carne. Ele descobriu o nome dos animais quando eles viviam como nós. Apesar de serem animais, antes eles viviam do mesmo modo que os Yanomami (Ballester, 2017b, p. 26-27).

"Sair de wayumï" pode ser também uma forma de amenizar um conflito dentro do xapono e, assim, uma possibilidade de evitar a cisão definitiva de um determinado grupo familiar. Quando o conflito é externo e com outros grupos, "sair de wayumì é também uma estratégia de defesa costumeira. Temendo represálias, após um ataque ao inimigo, os grupos se refugiam na floresta e, assim, dispersam os inimigos e escapam de uma nova incursão guerreira. Em todos esses cenários o tempo de ausência é variável, entre semanas a alguns meses, e estima-se que em regiões mais isoladas ou em tempos mais antigos o período total vivendo fora do xapono pode variar entre um terço e até metade do ano (cf. Good, 1989). No caso de grupos populosos, os acampamentos podem ser divididos em grupos e, no caso de saídas de tempo estendido, os grupos seguem se deslocando sucessivamente, em busca de comida ou fugindo de inimigos por exemplo, refazendo os acampamentos em cada paragem.

Como uma variante da estratégia de defesa guerreira, "sair de wayum‡" é também uma conhecida e eficiente prática para enfrentar surtos epidêmicos. Em um passado recente, as doenças infectocontagiosas disseminadas pelos Poowëteri - o "povo do machado", os "brancos" -, como a gripe, o sarampo, a coqueluche, a malária e a tuberculose, faziam com que as famílias se isolassem na floresta, a fim de evitar a propagação do contágio. Em diferentes regiões do território as histórias das epidemias que dizimaram famílias e comunidades inteiras estão ainda vívidas na memória coletiva. Estas doenças são nomeadas pelos Yanomami de xawara. Como explica Davi Kopenawa, xawara se refere a "todas as doenças de brancos que nos matam para devorar nossa carne" (2015, p. 366). E de acordo com os pajés, como o próprio Kopenawa:

Gente comum só conhece delas os eflúvios que as propagam. Porém nós, xamãs, vemos também nelas a imagem dos espíritos da epidemia, que chamamos de xawarari. Esses seres maléficos se parecem com os brancos, com roupas, óculos e chapéus, mas estão envoltos numa fumaça densa e têm presas afiadas (2015, p. 366).

Os surtos epidêmicos desestabilizam completamente a organização, a coesão e, obviamente, a saúde dos grupos locais. "Sair de wayumï", nessas circunstâncias, mais do que uma estratégia de defesa, é uma estratégia de sobrevivência e de resistência. Durante os períodos isolados na floresta, 
a depender do caso, a estadia pode ser conturbada, diferente do cenário ideal da expedição de caça e coleta coletiva com fartos resultados. É o que conta Kopenawa, num depoimento a Bruce Albert da década de 1990, período anterior a homologação da terra indígena e em meio à um verdadeiro surto de invasão de garimpeiros ilegais (história que se repete hoje em dia) e, consequentemente, das epidemias xawara trazidas e disseminadas por estes: "Hoje, os Yanomami nem fazem sua grandes malocas, [...] só moram em pequenos tapiris no mato, embaixo de lona de plástico. Não fazem nem roça, nem vão caçar mais, porque eles ficam doentes o tempo todo" (1990, p. 14).

Resistir contra a xawara implica em evitar os "eflúvios que as propagam", mas também em se afastar dos seres maléficos xawarari, estes que, não à toa, "se parecem com os brancos" (Kopenawa; Albert, 2015, p. 366). Como conta Kopenawa, "é acompanhando os objetos dos brancos" que a xawara se instala nas casas, "como convidados invisíveis" (2015, p. 368). Os seres maléficos xawarari acompanham as mercadorias dos Poowëteri e, diz Kopenawa, que "quando um avião carregado voa para nossa floresta, eles seguem atentamente o seu trajeto" e, antes mesmo de aterrissar, "começam a buscar humanos para devorar nos arredores" (2015, p. 368).

As epidemias que seguem "o caminho dos brancos" (Kopenawa; Albert, 2015, p. 306) não cessam e a descrição de Kopenawa, infelizmente, se atualiza, indo de encontro com o relato de um jovem Pukimapiwëteri do Alto Rio Marauiá, transmitido para nós através do orelhão da aldeia Pukima Beira. No dia que recebemos essa ligação (10 de abril de 2020) o Brasil contabilizava oficialmente (ou seja, considerando a subnotificação e a certeza de que os números eram ainda maiores) 19.943 infectados em todos os estados e 1.074 mortos pelo novo coronavírus, Sars-Cov-19. Do telefone, nosso amigo dizia ao Daniel, do outro lado da linha:

Heriyë [cunhado], eu estou preocupado, tem muito avião ainda voando aqui no nosso território. Eu fico preocupado porque eu estou pensando: de onde vêm esses aviões? Eu acho que a maioria vem de Boa Vista, e lá já tem caso confirmado de contaminação. Por isso eu estou pensando: esses medicamentos vêm de Brasília, se alguém em Brasília está contaminado e aí esse contaminado pega as caixas para por dentro do avião, aí o avião vai para Boa Vista com as coisas de medicamento e depois vai para Santa Isabel [do Rio Negro] e de Santa Isabel vem para o Marauiá, 
nosso território, aí que vai chegar essa contaminação. Por isso que eu e o $\mathrm{H}$. [liderança do Pukima Beira] estamos pedindo para a Sesai [Secretaria Especial de Saúde Indígena] parar com esses voos e deixar somente os voos de Santa Isabel, porque em Santa Isabel ainda não tá confirmado caso dessa xawara.

Um dia antes dessa ligação (9 de abril de 2020) o surto de Covid-19 fez sua primeira vítima entre os Yanomami. Um jovem do subgrupo ninam faleceu em Boa Vista e, "como uma segunda morte em vida" (Albert, 2020), não teve direito aos rituais funerários tradicionais e o sepultamento sequer contou com o consentimento e o diálogo adequado com seus familiares. Poucos dias depois a xawara chegou em Santa Isabel do Rio Negro e, conscientes do perigo que chegava cada vez mais perto, os Yanomami do Alto Rio Marauiá decidiram: sair para o mato para fugir da xawara.

As ligações com os Yanomami cessaram, e ficamos sabendo pelo povo de Santa Isabel que todos os servidores da Sesai e todos os Poowëteri - por determinação da associação local Kurikama - já estão fora do Rio Marauiá. Os Yanomami foram para o mato. Entre os Pukimapiwëteri as saídas de wayumí não aconteciam desde 2001, quando contam que pegou fogo na roça, por acidente, e acabaram os alimentos maduros, fazendoos com que saíssem do xapono e fossem para o mato coletar frutos e intensificar as caçarias (beneficiadas pelo afastamento e pelo deslocamento sucessivo). Atualizando a prática - tanto imanente quanto latente (cf. Gow, 2011, p. 39), que vem sendo abrandada em todo o território - contra a nova pandemia xawara, os Yanomami do Pukima Cachoeira e do Pukima Beira (quem tivemos notícias mais recentes) saíram todos dos xapono. Em grupo, os Pukimapiwëteri caminham pela mata, cujos caminhos e locais foram previamente discutidos, selecionados e abertos, e carregam tudo, inclusive microscópio e baterias, rádio e antenas, e, todos juntos, se refugiam na floresta.

A retomada da prática do wayumí como estratégia de resistência frente às epidemias xawara também tem sido feita em outras regiões do território. Segundo Dário Kopenawa, vice-presidente Hutukara Associação Yanomami que acompanha as movimentações pela radiofonia, saíram para o mato também grupos das regiões dos rios Cauaburis, Parawau e Demini (incluindo a sua família e seu pai Davi Kopenawa), no estado do Amazonas, e grupos ninam, no estado de Roraima (cf. Hamdan, 2020). Na região do Maturacá, do Rio Cauaburis e afluentes - das regiões que mais se sedentarizaram nas últimas décadas (cf. Nilsson \& Fearnside, 2011) 
- José Mário Pereira Góes (presidente da Associação Yanomami do Rio Cauaburis e Afluentes - Ayrca) conta que atualmente 12 famílias já saíram para o mato e outras se preparam para seguir o mesmo caminho, com alertas crescentes na cidade mais próxima de São Gabriel da Cachoeira. Segundo a liderança, a estratégia é a seguinte:

Quando uma família vai, outras famílias vão, a vizinhada vai. Porque na comunidade somos todos parentes, então eles levaram toda a família. [...] Levaram alimentos principais como farinha, banana, tapioca, beiju, e também café, açúcar, arroz, feijão e materiais de caça e pesca. E quando acaba os alimentos eles vêm buscar banana, pegar estoque de farinha (Hamdan, 2020).

$\mathrm{O}$ atual e estratégico afastamento de todos Poowëteri, saindo de wayumi e se isolando no mato, ressoa também com o período anterior (e, em parte, consecutivo) ao contato com os brancos, quando os Yanomami se encontravam em intensa movimentação, migração e expansão do território. No Marauiá, por exemplo, o afastamento por vezes é relatado como deliberada recusa, no sentido de uma "decisão política" (cf. Gow, 2011) e de uma "estratégia de sobrevivência" (Viveiros de Castro, 2019). Foi o que contou Adriano Pukimapiwëteri, referindo-se ao momento da fundação da missão salesiana no Médio Marauiá, quando "mensageiros" (pessoas encarregadas de trazer e fazer circular as notícias e convites para festas funerárias) chegavam ao acampamento onde os Pukimapiwëteri estavam de wayumi e contavam aos seus avós que o tais Poowëteri (Deusteri, como dizem, se referindo especificamente aos missionários, o "povo de Deus") traziam muitas coisas: "escola, missão, saúde" mas, também, "presentes, machado, enxada, terçado". O recado, essencialmente, transmitia aos patapata pë a intenção dos missionários de subir até o Pukima e fazer contato com mais esse grupo. Contrariando a proposta, conta Adriano, o seu avô dizia:

Não, não, não. Eu não quero. Eu não quero chegar perto dos brancos. Eu sei, eu sei que os brancos que estão chegando tão trazendo doença feia. Eu não quero que esse traga a doença. Eu sempre eu vou morar aqui no Centro [Pukima Centro, referindose a atração para as margens do Marauiá], nas cabeceiras que não tem doença. Não tem doença. Quando é pra baixo do rio, aonde passa os brancos, têm a doença feia. Eu não quero pegar essa doença. Eu não quero chegar. Eu não quero saber que tem branco. 
A recusa em seguir "o caminho dos brancos", tal como dito por Kopenawa (2015, p. 306) e reafirmada pelo avô do Adriano, ecoa com outra reflexão de José A. Kelly Luciani a partir do que os seus interlocutores também se referiam como "o caminho dos brancos" (traduzido por ele como "path/trail of the napë" ou napë's path; cf. 2011, p. 176). Sugere ele que assim como os Yanomami "falam do passado como movimentos na floresta, referindo a lugares de antigas residências, roças e acontecimentos", o próprio "progresso" - uma vez seguido o "caminho dos brancos" - é "explicado como uma trajetória ao longo de um caminho" (Luciani, 2011, p. 176-177). E assim sintetiza a ideia: "Deslocar-se elicita [elicits] a narração da história; a história pode assumir a forma de um trajeto. É apropriado, então, que o progresso seja expresso como uma trajetória" (Luciani, 2011, p. 177). O contexto dessa reflexão era justamente um encontro para discutir a situação da saúde indígena na região do Alto Orinoco, na Venezuela, e assim argumentava um enfermeiro yanomami do Rio Ocamo, não como recusa, mas pelo contrário, a favor do tal "progresso": "O problema é importante. Por que isso é importante? Porque a xawara está sempre nos atacando. [...] Se nós já estamos no caminho dos brancos, por que que nós não estamos virando enfermeiros?" (Luciani, 2011, p. 176).

A situação do momento com a Covid-19, entretanto, é distinta. E, ao menos como seguido por alguns grupos yanomami, implica na tomada de outro caminho, o caminho tal qual faziam os antigos, o caminho do wayumi, longe dos brancos (inclusive enfermeiros e enfermeiras, potenciais fontes de transmissão). O momento é parcialmente inédito e, parafraseando José A. Kelly Luciani, mais uma vez uma epidemia xawara elicita (elicits) a história; a história assume a forma de um trajeto; e o "progresso" (ou "regresso") é expresso como uma trajetória, nesse caso de recusa, uma saída de wayumi, fugindo para o mato. A situação, assim, inverte o movimento de aproximação às margens do rio, decorrente do contato e da implantação dos sistemas de saúde do Estado, num sentido simetricamente oposto, o "re-isolamento voluntário" (Viveiros de Castro, 2019, p. 14). Em um movimento contrário e atento aos altos riscos de contágio através de profissionais de saúde e outros não-indígenas possivelmente contaminados transitando pelo rio, os Yanomami pedem para que todos os não-indígenas se retirem da região do rio Marauiá. Ao mesmo tempo em que saem de suas aldeias e se refugiam longe das 
margens dos rios, deixando para trás as escolas e postos de saúde, indo de wayumi para o mato e voltando para o "toco das serras", como diz Adriano, onde habitavam antes do contato com os Poowëteri. Nesse movimento, renunciam e recusam a atual proximidade e o convívio com os napë pë, antecipando uma eventual nova catástrofe e evitando deliberadamente e temporariamente a presença do Estado e seus agentes.

Através desses caminhos mata a dentro é notável que para além dos relatos que povoam os movimentos pela terra-floresta, a floresta em si é marcada tanto pelos rastros e pelos caminhos (mayo, peiyo) quanto pelos artefatos ou construções que, como diria Alejandro Reig, "adornam" e "equipam" a floresta (2013, p. 145). Essas pequenas intervenções na floresta constituem-se nas trilhas em si, mas também em pontes feitas de troncos e cipós para atravessar cursos d'água; andaimes e anéis de cipó para subir nas palmeiras e coletar frutos; buracos para pilar o timbó; penas do rabo do mutum fincadas em linha reta na terra como testemunho das habilidades de um caçador; cortes nas árvores marcadas pelo facão ou galhos quebrados à mão demarcando os caminhos; e pequenos tapiris chamados de yãno, as vezes um conjunto deles numa exígua clareira, que em diferentes estágios de conservação ora se confundem com os troncos das árvores e ora despontam na mata, com suas coberturas de palha ainda intactas ou com a clara geometria de base triangular dos esteios fincados no solo.

Os yãno são abrigos temporários construídos na floresta de forma ligeira e em diferentes situações, como nas saídas de wayumi̇ (por distintas razões, como vimos), mas também em processos de mudança e construção de novas roças e novas aldeias, antecedendo as casas construídas de forma mais cuidadosa e duradoura; em expedições e caçadas coletivas na floresta, que duram vários dias e costumam ser feitas durante as festas funerárias reahu, chamadas de henimou; ou ainda durante viagens mais curtas, de apenas alguns dias, visitando outras comunidades ou indo e voltando da cidade mais próxima. Essas estruturas ligeiras, leves e transitórias são formas essenciais ao "jeito de pendurar redes" e embora as formas de se construir o yãno variem de modo orgânico, as variações formais, técnicas ou materiais transformam-se a partir de um tema comum: o arranjo triangular dos esteios, das vigas e das redes atadas a ela, em torno de uma fogueira central. As palavras nas diferentes línguas yanomami também variam, mas a estrutura elementar do yãno é uma constante. Como observa 

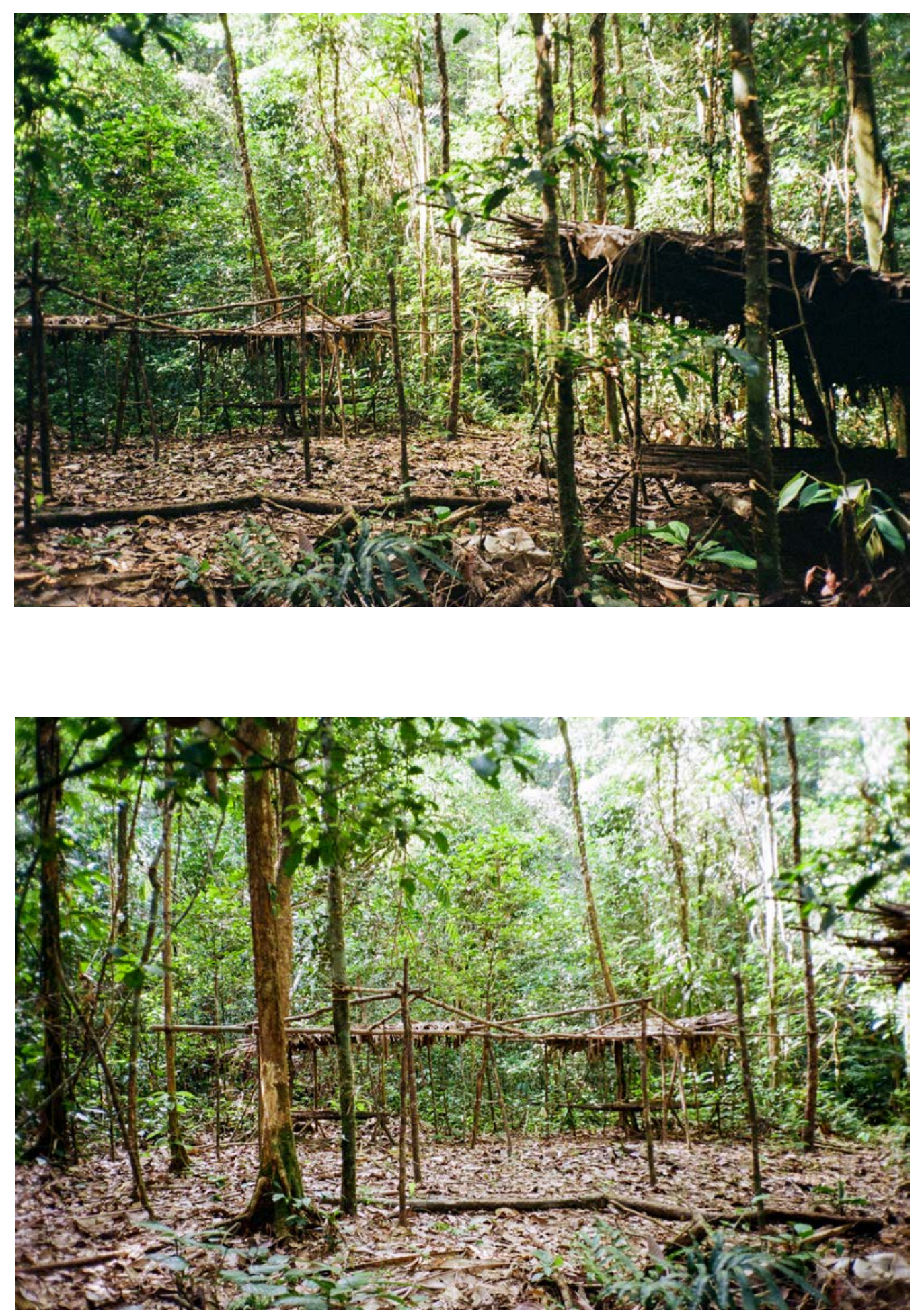

Fig. 14/15. Conjunto de acampamentos (yãno) abandonados e, antes, utilizados em uma expedição de caça (henimou), situado ao longo de uma trilha que parte do xapono Pukima Cachoeira (2019) 
o linguista italiano Ernest Migliazza, figura importante na sistematização das línguas yanomami em torno de uma família comum, "o único modelo de habitação comum a todos Yanomami é o abrigo temporário" (1972, p. 412).

Ao navegar pelo Rio Marauiá vê-se uma série de yãno em pequenas clareiras nas margens dos rios - separadas da beira por um trecho de mata, mantendo certa reserva, e com o chão limpo o suficiente para ocupar o espaço com um ou alguns yãno, enquanto que no nível das copas mantemse parcialmente sombreada pelas árvores ao redor. Essas estruturas são construídas nas idas e vindas da cidade de Santa Isabel do Rio Negro e servem como acampamentos para pernoitar durante a viagem que pode durar vários dias. Essas viagens costumam ser feitas em grupos, com dois ou mais barcos cheios de gente, às vezes de xapono distintos, mas sempre de grupos aliados e com boas relações de afinidade, que se ajudam nas travessias das cachoeiras e acampam juntos, cada qual em seu yãno. Os pernoites são sempre feitos nestes acampamentos e a viagem a duração da viagem é calculada sempre em função dos locais de acampamento, de acordo com a carga e potência do barco e do motor e o nível da água do rio. De modo que ao perguntar quanto tempo a viagem demorará a resposta costuma ser a enunciação dos prováveis locais de acampamento, já previamente planejados e também previamente ocupados por esses e outros grupos. Assim, as pequenas clareiras já se encontram abertas e, por vezes, inclusive, os yãno já se encontram prontos, pré-construídos por um grupo que passou antes por ali, no caso de não ter sido destruído com o tempo ou, eventualmente, para virar lenha.

A viagem costuma conter paradas em alguns xapono para usar o rádio e transmitir notícias da viagem para os familiares e, eventualmente, a parada também serve para transmitir notícias para os residentes do xapono de parada. Nesse caso, entra-se discretamente no xapono, pelo fundo das casas ou tentando ser discreto caminhando pelos beirais sombreados das casas, na soleira com o terreiro central. Essas visitas, comuns nos regimes de deslocamento e movimentações atuais, em função das idas à cidade, são destituídas das prerrogativas cerimoniais das visitas mútuas (que ainda ocorrem, em paralelo) para se fazer convites ou se fazer presentes nas festas funerárias reahu, para trocas de bens e trocas de ensinamentos com os pajés, ou, de forma reinventada atualmente a partir das formas anteriores, para comparecer em assembleias da associação local, a Associação Kurikama Yanomami. Nestas, a chegada dos convidados no 
xapono em que se realizará o evento é marcada por uma espécie de forma ampliada e condensada na apresentação cerimonial que ocorre nas festas reahu. E os representantes políticos do xapono, cerca de dez normalmente, que chegam ao xapono aliado pela associação, adentram o terreiro central todos pintados, adornados e armados, dançando e cantando com uma tônica guerreira, reinventada para o atual contexto.

Os pernoites durante as viagens pelo rio, entretanto, nunca são feitos em algum xapono, independente de ser aliado ou não. A restrição, completamente implícita no planejamento das viagens, provavelmente pretende evitar a completa destituição das prerrogativas cerimoniais que o pernoite no xapono de um grupo aliado costuma prever, tal como numa festa reahu ou numa assembleia da associação. Ao mesmo tempo, a restrição parece decorrer também de razões sociopolíticas, evitando conflitos latentes que podem ser disparados pela permanência junto aos residentes de tal xapono, resultando, inclusive, em ataques ou feitiços causados pelos pajés locais. Assim, não se dorme "à toa", como se diz, num xapono alheio. Desta forma, os yãno nas margens do rio reinventam os mesmos yãno que eram construídos ao longo das trilhas pela mata que conectavam (ou ainda conectam, em poucos casos) os xapono vizinhos e aliados. Desde a década de 1990, ao que parece, com o acesso facilitado a botes e canoas e a motores à combustão - comprados, trocados ou ganhados, como vimos na prática dos missionários salesianos que davam barcos "de presente" para facilitar o contato e a aproximação - os caminhos que conectam os xapono foram substituídos pelos caminhos fluviais, mais ágeis de serem percorridos, menos cansativos fisicamente, mas, sobretudo, muito mais eficazes para transportar cargas e materiais dos mais diversos, tanto pelos Yanomami quanto pelos serviços de saúde ou educação do Estado e município - estes, como vimos acima, evidentemente estimularam essa nova prática a fim de facilitar a logística e gestão dos postos, escolas e afins.

Nestes yãno reinventados pelos novos caminhos fluviais, um dos materiais que constituem sua estrutura elementar também é transformado de maneira estratégica. As lonas plásticas, adquiridas na cidade, substituem, assim, as coberturas de palha, de modo que a mesma lona que serve para proteger pessoas e coisas dos temporais nas viagens de canoa pelo rio, serve também para cobrir os acampamentos. Estas são atadas com muita agilidade na hora da chegada, antes do anoitecer; e antes de partir, pela manhã, são agilmente recolhidas, dobradas e guardadas 


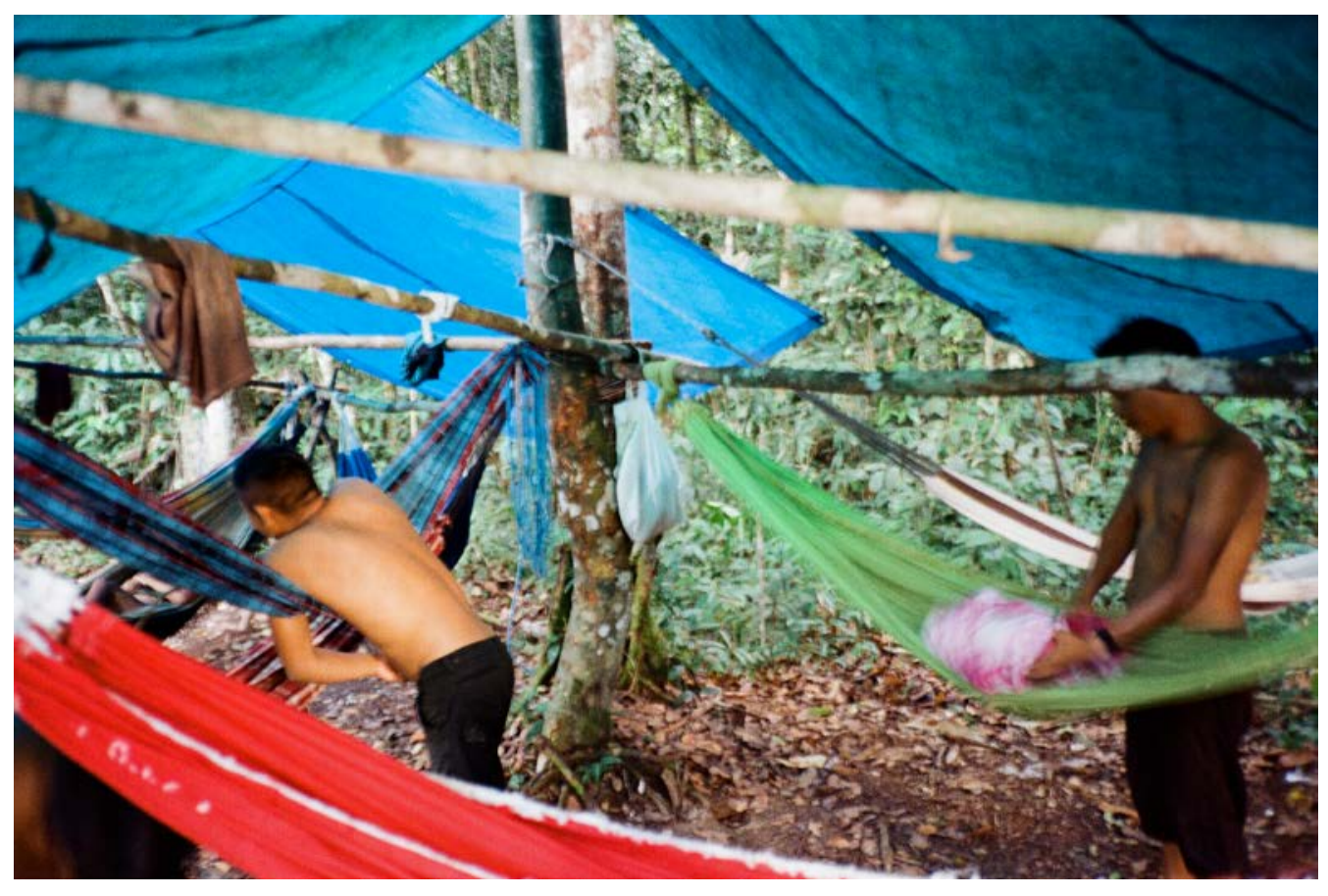

Fig. 16. Triângulo de redes em um acampamento (yãno) na beira do Rio Marauiá, coberto com lonas plásticas e utilizando o tronco de uma árvore (hii hi) como esteio improvisado, registro de uma das noites de nossa viagem rio acima em 2019 com os Yanomami do Pukima Beira. 
de volta na canoa. Além disso, a construção com o teto de palha está sujeita a disponibilidade das palmeiras adequadas na área, o que nem sempre ocorre. Nesses casos, é necessário percorrer distâncias maiores a pé no mato para buscar o material, o que pode atrasar a viagem e a construção do abrigo, feito idealmente de maneira cronometrada antes do anoitecer. Dessa forma, a alteração do material corresponde também a uma transformação da forma do yãno. Assim, o plano inclinado e mais ou menos retangular de ripas e folhas de alguma palmeira, que fechava a parte superior do triângulo de apoios do yãno, é substituído por uma lona esticada mais acima dos triângulos de esteios e redes, tensionada pela cumeeira com corda ou cipó entre duas árvores, formando uma cobertura de duas águas, com as pontas amarradas e esticadas em paus fincados na terra ao redor do acampamento. A transformação, todavia, poderia ser vista como uma transformação estrutural aplicada à arquitetura, como propõe Claude Lévi-Strauss (2001, p. 29), de modo que através da variação de materiais, formas e técnicas - da palha ao plástico - mantém-se os sentidos mais fundamentais da estrutura do yãno, ainda estrategicamente aperfeiçoados: a agilidade, a efemeridade e a ligeireza.

Numa destas viagens, quando subíamos o rio até suas cabeceiras, em direção ao Pukima Cachoeira, paramos numa clareira em que não havia nenhum yãno pré-montado, embora a clareira já estava aberta, ao lado de um igarapé no seu encontro com o Marauiá. Assim que os dois barcos que faziam a viagem encostaram na beira, um do Pukima Beira e outro do Pukima Cachoeira, homens de cada um dos barcos pularam dos botes e se meterão rapidamente mata adentro para buscar cipó, lenha e as "varas", isto é, os esteios e as vigas, para compor com as árvores da pequena clareira e rapidamente montar dois yãno. Em poucos minutos escutava-se o som dos paus sendo arrastados pelas folhas, abrindo novos caminhos improvisados com o facão, e rapidamente todos retornaram a clareira, onde descarregávamos as bagagens e as crianças brincavam. É comum que as construções dos yãno façam uso também das árvores de pé e preexistentes na ao redor da clareira para compor sua geometria triangular, fazendo as vezes de um ou dois apoios verticais, de forma que agiliza ainda mais a sua execução, evitando a necessidade de derrubar uma árvore na mata para depois fincá-la no solo. Assim, para um dos yãno, mediam o vão entre duas das árvores com a abertura dos braços e olhos atentos. Poucos minutos depois voltam com um pau nas costas, 

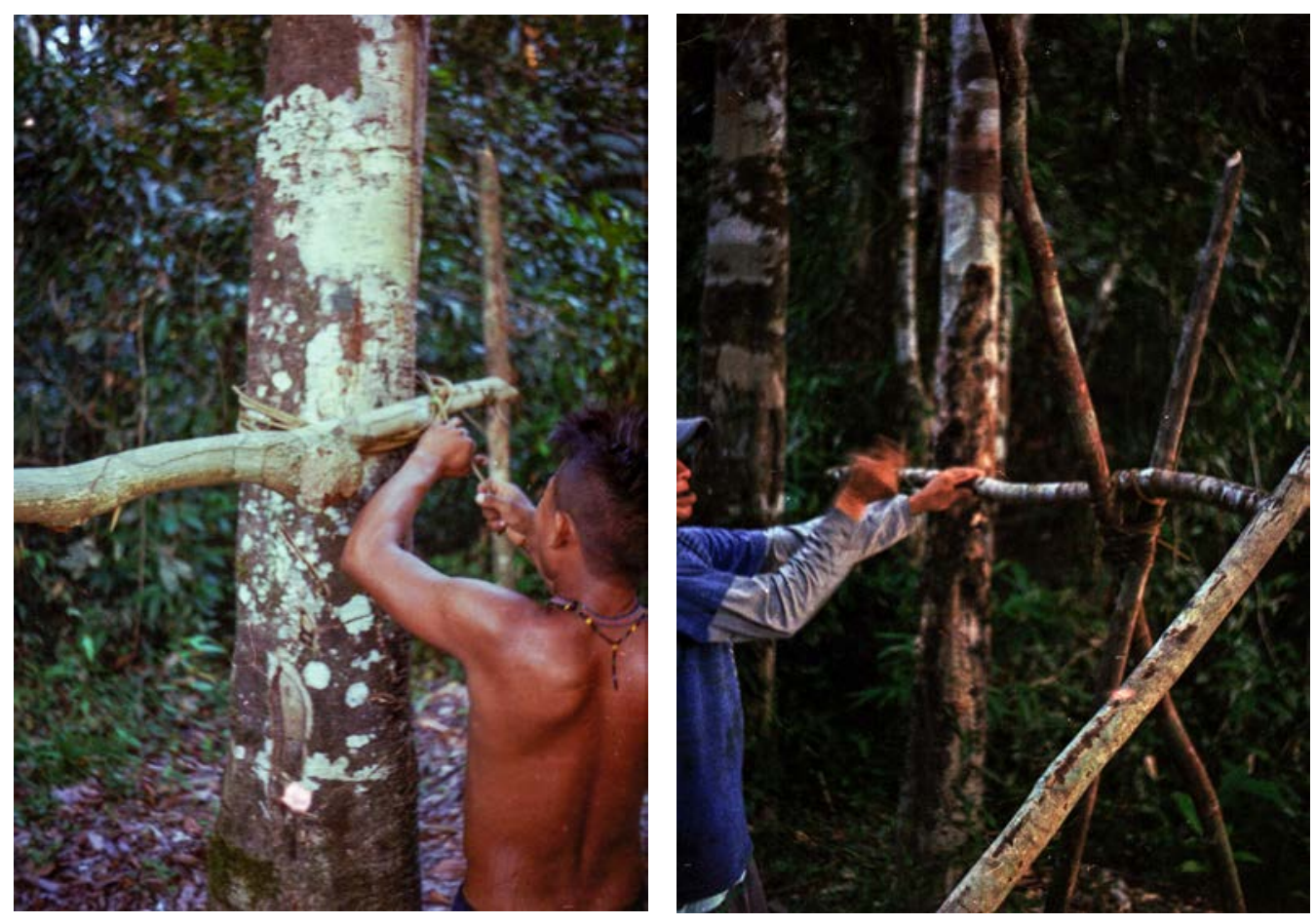

Fig. 17/18. À esquerda, Marciel do Pukima Beira, à direita, Claudio do Pukima Cachoeira, construindo dois tapiris (yãno) em um acampamento na beira do Rio Marauiá durante nossa última ida em 2020. 
aparentemente cortado de forma precisa. Por poucos centímetros o comprimento não é o bastante e a solução vem de imediato: corta-se um pedaço, para afastá-lo da árvore, pega-se mais dois pedaços menores e faz-se um fino apoio em "X", um tripé de duas pernas, como costumam fazer durante a ágil montagem do yãno, de forma que dispensa madeiras mais grossas e mais duras, e por isso mais demoradas e trabalhosas de cortar e encontrar.

A execução toda é muito rápida e não passa de uma hora entre o momento que encostamos e que penduramos nossas redes. Os nós são rapidamente atados com cipó, unindo toda a fina estrutura de paus roliços, cujos vãos são modulados de acordo com o tamanho padrão das redes de dormir, de maneira que o tamanho do yãno é precisamente o tamanho mínimo necessário para que, em torno do fogo, comporte-se três redes ou, eventualmente, seis redes, se sobrepostas umas as outras - ou mais, se amarradas também em outros apoios, estendendo a estrutura com mais esteios ou fazendo uso das árvores ao redor. Neste arranjo, modulado dessa forma, o triângulo tem uma tal escala que facilita encontrar as madeiras adequadas nos arredores da clareira improvisada e, inclusive, permite que qualquer um, deitado em sua rede, alcance com os braços o centro onde encontra-se a fogueira, mantida acessa durante toda a noite. O tempo de construção é também ele modulado, acertado de acordo com a luz do dia, de modo que após a montagem da estrutura, ainda com o céu claro, o fogo é acendido, as redes são atadas e, enquanto uns descansam e tomam banho, outros vão tentar a sorte numa rápida caçada ou pescaria. Durante a noite, antes de dormir, vozes e risos brotam das redes de todos os lados do triângulo, forma essa que, mais do que um modo elementar de construir, é também a forma elementar de convivência ao redor do fogo.

No dia seguinte, desmontamos a lona e partimos cedo. Ao anoitecer, fizemos outro acampamento em um local rio acima onde já haviam estruturas pré-montadas. Apesar de frágeis, estas foram rapidamente reforçadas, refazendo os nós com cipós e com as cordas à mão, substituindo algumas peças ou adicionando alguns apoios com a solução em "X". Nesse local havia também um yãno que me chamou a atenção, feito do modo tradicional, com cobertura de palha, esteios baixos nos fundos e mais alto na ponta, dando a inclinação do telhado, e planta de base triangular. Maciel, um jovem amigo e interlocutor do Pukima Beira que estava conosco, explicou o possível motivo daquele yãno ter sido feito daquela 
forma; apenas apontou para o lado, onde haviam várias sorococas (ou banana-brava-da-mata, Phenakospermum guianense) - o suficiente para usar suas folhas (këtipe) para cobrir o yãno daquele jeito - e, sem muitas palavras, simplesmente deu a entender que aquilo dispensava o uso de lonas plásticas. Nesse mesmo contexto e a partir do mesmo yãno, Maciel me explicou os nomes dos componentes da estrutura do yãno, que segundo ele "é tudo nome da floresta" - afirmação que corresponde, penso eu, a um destaque ao jeito apropriado e propriamente yanomami de fazer e de nomear os tapiris. Os esteios simples e feitos com apenas um pau, em qualquer um dos três vértices do triângulo (praticamente equilátero), são chamados de itaorewë; e quando são feitos com a solução em "X" ou com três paus, como um tripé, são chamados de xeketeorewë; e as árvores que eventualmente são utilizadas como um esteio natural são chamadas de hii hi, "pau", num sentido genérico.

As vigas (ou travessas) que unem e travam os esteios podem ser chamadas de forma genérica de pariparima. De forma mais específica chama-se de xíkahamirereorewë a viga que une os dois esteios da base do triângulo, concebido como o fundo ou parte posterior da morada temporária, onde o teto é mais baixo. Xíkahamí, justamente, significa aquilo que está "na parte baixa do teto, nos fundos da morada", sendo que xîka é um substantivo (nome) que indica "a parte posterior de uma morada coletiva ou de um refúgio familiar, a parte baixa de um teto"; enquanto que -hamí é um morfema locativo (Lizot, 2004, p. 390/41). Rere-, por sua vez, é a raiz verbal do verbo transitivo rereat, que significa "colocar horizontalmente (objetos compridos)", como um tronco (hii hi) utilizado como uma viga; e o sufixo -rewë é um nominalizador que transforma a raiz verbal em nome, sendo que o nome resultante corresponde a ação que o verbo realiza (Lizot, 2004, p. 353/354).

Já as vigas colocadas de forma oblíqua, unindo e travando os dois esteios do fundo do yãno com o esteio mais alto, na ponta do triângulo, são chamadas de yakiraorewë. Assim como o elemento anterior, a forma pela qual este é construído e disposto corresponde ao modo pelo qual o nome é composto gramaticalmente. Ambos partilham o mesmo sufixo nominalizador -rewë e, nesse caso, yakira- corresponde à raiz verbal do verbo transitivo yakiraai, que indica o ato de "cruzar dois objetos compridos", dispondo-os em forma de "X" (Lizot, 2004, p. 493). A forma cruzada, por sua vez, corresponde ao modo como essas vigas obliquas 


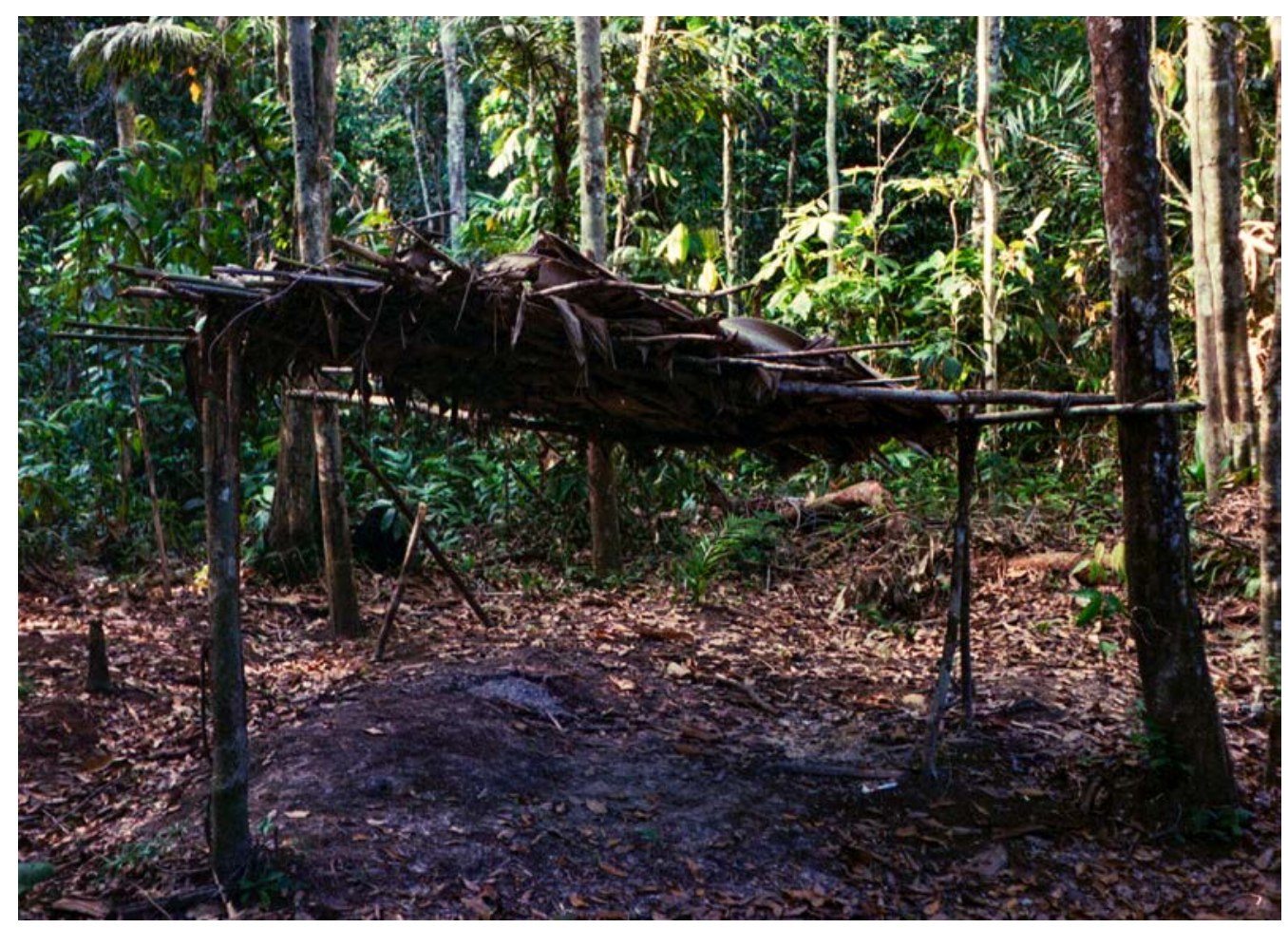

Fig. 19. Pequeno tapiri (yãno) "típico" com cobertura de palha de sororoca (këtipa) abandonado em um acampamento na beira do Rio Marauiá (2020). 
costumam ser colocadas, de modo que se cruzam no ponto de encontro com o esteio alto da ponta do triângulo, permitindo que o telhado avance um pouco mais, aumentando o beiral e, com isso, a área interna e coberta da morada temporária. Nos yãno maiores, as vigas cruzam-se, simetricamente, formando um " $\mathrm{X}$ ", enquanto que nos menores as vigas são interrompidas após o cruzamento com o esteio da ponta, formando um "V". Essa variação determina a escala e a área coberta pela estrutura do yãno mas varia sobretudo em função do tempo de permanência no local. Quando o tempo é abreviado, como nas viagens rio acima e rio abaixo, opta-se normalmente pela solução em "V"; quando o tempo é mais estendido, como nas saídas de wayumit, opta-se pela solução mais ampla em "X".

Os elementos que compõem a trama da cobertura do yãno são chamados de horohoromi. Estes são normalmente compostos de caibros, cortados com uma mesma dimensão e dispostos de forma paralela ao sentido da altura do triângulo (ou seja, perpendiculares à base). Estes apoiam-se sobre as vigas e nas pontas prolongam-se um pouco, tanto nos fundos quanto na parte mais alta, ganhando ainda mais área coberta e resultando num teto de forma mais retangular - e não triangular, como a disposição dos apoios verticais. Dependendo do tipo de palha que será usado na cobertura do yãno são colocadas peças que funcionam como ripas, cuja função é de fixar as folhas que vão compor o teto da morada. Estas também são chamadas de horohoromi e são dispostas de forma transversal aos caibros (ou seja, paralelas à base). Em acampamentos menores, como o yãno que observava com meu interlocutor, estas peças transversais são postas diretamente sobre as vigas (isto é, sem os caibros, no outro sentido), também com uma medida comum e resultando num teto retangular, embora mais enxuto e mais frágil.

Por fim, os nós de cipó (too), normalmente utilizando o cipó titica (masimasima, Heteropsis flexuosa), amarram todo o esbelto conjunto de esteios e vigas, unindo-os em seus pontos de encontro. Os nós envolvem as peças e podem ser feitos de duas formas. A solução mais simples, em que a volta é feita em apenas num sentido, em forma de "/", é chamada de okaorewë; enquanto que os nós mais resistentes, com voltas nos dois sentidos, em forma de "X", são chamados de okaoyakiraorewë. Oka- é a raiz verbal do verbo transitivo okaai que significa "atar, amarrar, fixar" (Lizot, 2004, p. 281) e, assim como o sufixo nominalizador 
-rewë, é compartilhada pelos dois termos. Mas no caso do nó em " $\mathrm{X}$ " (okaoyakiraorewë), em específico, o ato de atar (okaai) é somado ao ato de cruzar (em "X", justamente), correspondente à raiz verbal yakira- e ao verbo transitivo yakiraai.

O processo de construção do yãno pode ser dito, ao menos, de três maneiras distintas. Primeiro, yãnomou, em que o sufixo -mou transforma o substantivo (yãno) em verbo e poderia ser traduzido como "fazer o yãno". Yãno, por sua vez, corresponde ao "tapiri", ao "acampamento no mato" e a "morada temporária na floresta", como vimos, mas como indica Jacques Lizot o termo refere-se também ao fogo doméstico, centro do espaço habitado, tanto na floresta quanto no xapono, onde preparam-se os alimentos e esquenta-se durante a noite (2004, p. 495). A outra forma é dita mimou. $M i$ - é a raiz verbal do verbo intransitivo miõ que significa "dormir". Mimou, por sua vez, enquanto verbo intransitivo, significa a decisão de "se pôr a dormir", e enquanto verbo transitivo significa "construir tapiris", "construir refúgios temporários para passar a noite" e "instalar-se para dormir" (Lizot, 2004, p. 211). E a última, se diz përimou, verbo transitivo que significa "instalar-se para passar a noite" e "construir um refugio temporal" (Lizot, 2004, p. 307).

A raiz verbal përí-, com o sentido de "deitar na rede", e os verbos que dela derivam, entretanto, extrapolam o processo construtivo do yãno e merecem uma leitura mais detida. Përí, por exemplo, é um verbo intransitivo que significa "morar" e "viver" em um lugar determinado uma região, uma casa ou uma aldeia em específico, como me explicava Neide, professora do Pukima Cachoeira e filha do përiomí Adriano -, mas também, conforme indica Lizot, "habitar" e "entrar ou estar em uma rede" (2004, p. 307). De forma análoga, no que diz respeito à extensão semântica da raiz verbal, enquanto verbo transitivo, përiamaí significa "colocar em uma rede (um objeto, uma pessoa)" e përiamapou significa "dar abrigo a alguém" (Lizot, 2004, p. 307). E, enfim, enquanto um verbo de estado, përia significa "estar deitado em uma rede", no sentido de um momento preciso e em um lugar preciso, o que corresponde ao sentido de "viver em um determinado lugar" (Lizot, 2004, p. 307). Assim, nota-se que amplitude semântica do conceito de përio engloba o "estar em uma rede" com a ideia mais geral, embora sempre em um lugar em específico e nunca de forma genérica, de "morar" e "habitar".

Os conceitos de përio e përía ressoam com a ideia de yãatamotima 
- "o jeito de pendurar redes" - através da raiz verbal yã-, que indica tanto a ação de "pendurar a rede" (com o verbo transitivo yãai) quanto o estado de "ter a rede atada em um lugar" (com o verbo de estado yãa), justamente no sentido de morar, habitar ou viver em um certo lugar. Dessa forma, a raiz verbal yã- compartilha com raiz verbal përi- não apenas uma amplitude semântica - esta que aproxima o "estar numa rede" ao ato do "habitar" -, mas uma especificidade daquilo que constitui propriamente esse ato de viver, morar e habitar, isto é, "o jeito de pendurar redes". Como me dizia Neide, explicando os sentidos de përt- e as possíveis traduções para "morar", os verbos de estado përia e yãa têm um sentido compartilhado, de modo que ao mesmo tempo que podemos dizer "weti ha wa yãa?" pode-se também dizer "weti ha wa përía?", sendo que ambas as formas significam tanto "onde você mora?" quanto "onde você pendura sua rede?". Assim, se a noção de habitar corresponde ao ato de "pendurar a rede", esse está intrinsecamente relacionado e situado a um lugar e a um tempo em específico, seja de modo mais intermitente num yãno, seja de menos mais estável num xapono, como destacado pela minha interlocutora. De modo que talvez a tradução mais precisa fosse, ao invés de "onde você mora/pendura sua rede", "onde você está morando/pendurando sua rede", naquele momento e local específico e situado, portanto.

A especificidade do lugar habitado no momento, condição implícita do ato de habitar, dialoga também com a noção de urihi ("terra-floresta"). Como vimos anteriormente, é através do movimento pelos caminhos da floresta, habitando distintos lugares e regiões, que a noção de urihi é produzida, conjugando relações temporais e espaciais de um determinado grupo no passado e no presente - assim como a história concebida como um trajeto, como propõe Luciani (2011, p. 177). Dessa forma, ao longo dos caminhos trilhados pelo "povo da terra-floresta" (urihiteri pë), as expressões como "a nossa floresta" (kamiyë yama ki urihi pë) ou "a minha terra" (ipa urihi) designam a área habitada atualmente, mas, num sentido maior, a conecta a outra rede de caminhos, trilhados pelos mais velhos e pelos antepassados, como indica a fala de Adriano: "Essa floresta [urihi] é nossa, nós somos os donos, aqui que eu nasci, aqui que meu pai nasceu". Assim, a ideia de urihi conjuga as relações temporais e espaciais de um determinado grupo do passado e do presente, indicando o local onde se habita (përia) naquele instante - isto é, onde pendura sua rede - ao mesmo tempo que o vincula, numa perspectiva e numa escala estendida 

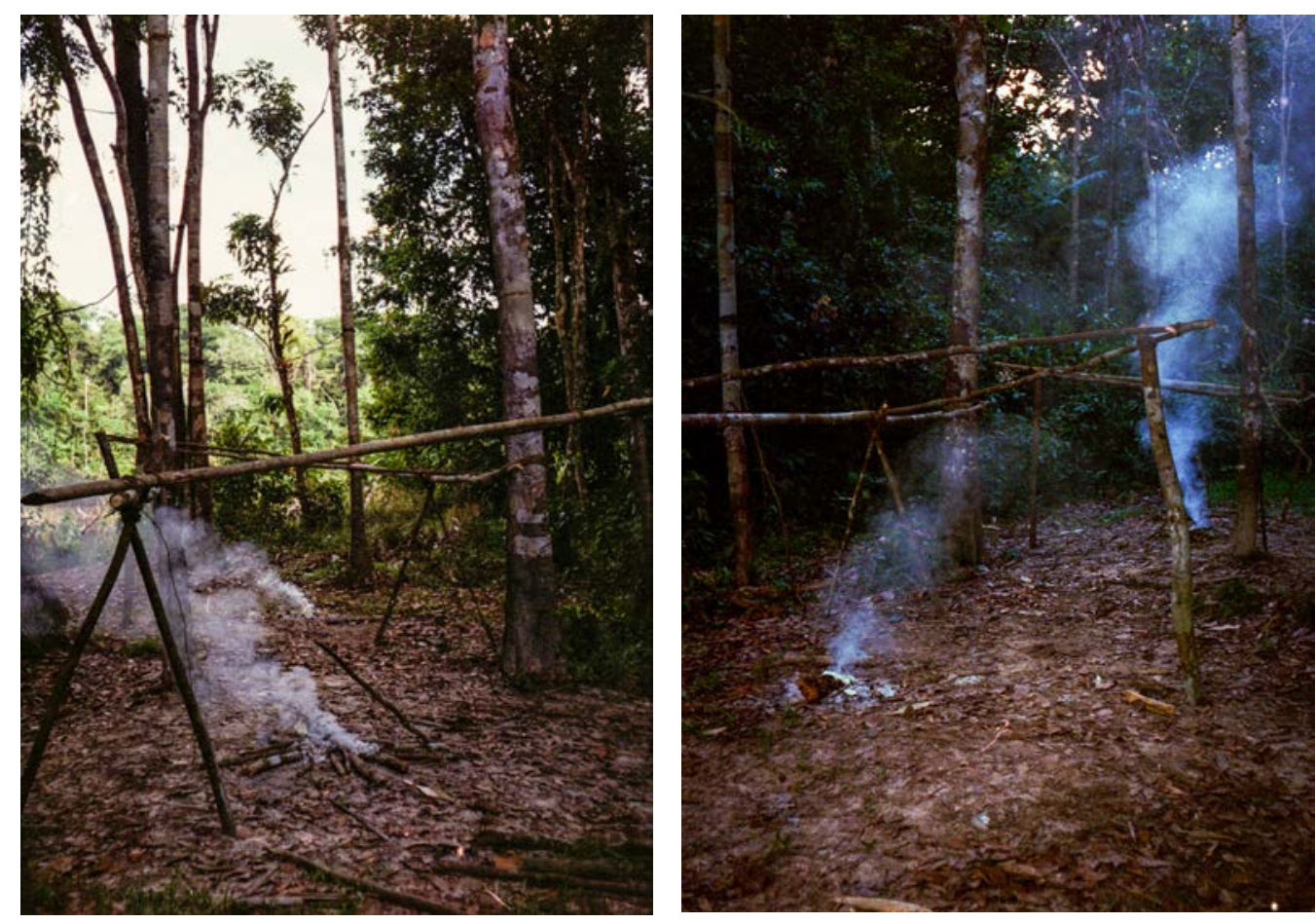

Fig. 20/21. Dois tapiris (yãno) recémabandonados em um acampamento na beira do Rio Marauiá (2020). 

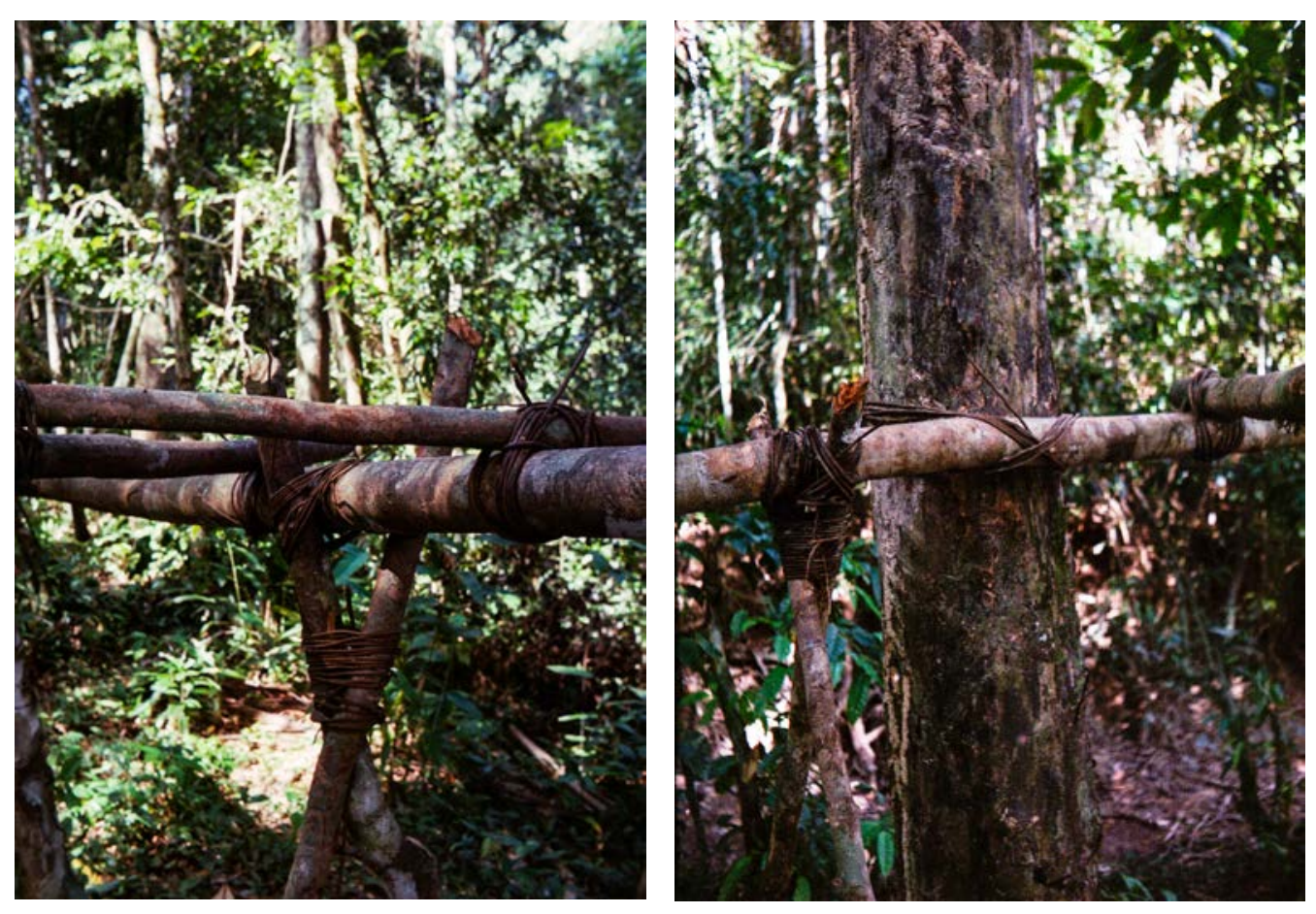

Fig. 22/23. Detalhes construtivos de dois tapiri (yãno) na beira do Rio Marauiá (2020). À esquerda, detalhe do cruzamento da viga dos fundos (xîkahamirereorewë) do yãno com uma das vigas oblíquas (yakiraorewë) sobre o esteio em forma de "X" (xeketeorewë). À direita, esteio em "X" reforçado com apoio adicional em uma árvore (hii hi) ao redor do yãno com amarração em "X" (okaoyakiraorewë). 
temporalmente e espacialmente, aos espaços e clareiras habitados pelos antepassados - onde estes penduraram suas redes.

Assim, o sentido de habitar que estes verbos e conceitos apresentam talvez poderiam ser melhor traduzidos, ainda que apenas de forma heurística, por "o lugar onde penduro minha rede". Lugar este, portanto, situado no tempo e no espaço da terra-floresta e, por sua natureza relacional, continuamente efêmero e móvel, já que pode ser cindido ou deslocado junto de um grupo cuja estabilidade e bem viver é colocado em cheque, migrando para outro local e pendurando suas redes num novo yãno ou um novo xapono. Em ambos os casos é em torno do fogo que as redes são penduradas e, segundo Lizot, uma pergunta como "weti kë iha wa yãõma?" poderia ser traduzida tanto por "em que casa você morava?" quanto por "em qual fogueira você pendurou sua rede?" (2004 p. 485). O exemplo de Lizot dialoga com o exemplo dado pela interlocutora do Pukima Cachoeira, que traduz yãa- tanto como "morar" quanto "pendurar a rede", mas estende a especificidade do morfema locativo ha (do exemplo anterior, "weti ha wa yãa?") com o locativo iha ("weti ke iha wa yãoma?"), que indica especificamente uma localização relacionada à casa (Lizot, 2004, p. 123) e, nesse sentido, o lugar do fogo doméstico, no entorno do qual se penduram as redes.

Tanto nos tapiris (yãno) quanto nas casas que compõem o xapono, o lugar do fogo constitui-se numa centralidade da maior importância. No caso do yãno, como vimos, o fogo situa-se no exato centro da morada temporária, entre as três (ou seis, se sobrepostas) redes penduradas dos esteios dispostos como um triângulo. E nas moradas familiares do xapono o fogo doméstico situa-se nos fundos da casa - dependendo da morfologia da construção na parte mais baixa do telhado -, espaço conhecido por hato nahi xĩka. Hato nahi é um termo que indica uma morada familiar dentro do xapono e xĩka é um substantivo que indica "a parte posterior de uma morada coletiva ou de um refúgio familiar, a parte baixa de um teto" (Lizot, 2004, p. 390), termo que poderia ser traduzido literalmente por "os fundos da casa".

Onde se situam as fogueiras utilizadas para cozimento, para o preparo dos alimentos e também para esquentar-se é onde o convívio doméstico desvela-se em seu sentido mais intenso. É em torno do fogo em que a família nuclear ou um grupo de parentes e afins (numa visita à outra casa ou numa viagem pelo rio, por exemplo), se reúne, sobretudo 
ao anoitecer, para compartilhar a comida mas, também, os relatos do dia ou dos tempos antigos, contando histórias ou engajando-se em diálogos que atravessam a noite e, assim, reforçando laços e transmitindo conhecimentos. Como escrevem Janet Carsten e Stephen Hugh-Jones, na introdução da coletânea de artigos About the house, poderíamos dizer que "a fogueira [the hearth] é tanto uma característica definidora da casa quanto comer juntos é uma característica definidora do parentesco" (1995, p. 42). Nesse mesmo sentido, o título dado por Lizot a um de seus livros, "O círculo dos fogos [Le cercle des feux]" (1988), é preciso como forma sintética de retratar os Yanomami através desse elemento central na sociabilidade dos grupos locais, multiplicado pelo círculo de casas ou acampamentos (yahi ou yãno) cada qual com suas respectivas fogueiras. Como comenta Reig, subjacente à escolha do título "está uma afirmação de que os laços históricos de descendência são mantidos juntos no atual plano de aliança, que por sua vez são subjugados pela primazia da reunião do grupo [village gathering, no original]", reunião esta que conforma a expressão atual do "viver junto" (yaiprou), seja construída como um xapono ou como um conjunto de yãno, e, como complementa o autor, enquanto "unidade social composta de uma iteração [no sentido de repetição, multiplicação ou somatória] de espaços domésticos associados" (2013, p. 171, nota 96).

É "nos fundos da casa" (hato xĩka), ao redor do fogo, que a estrutura de base triangular do yãno é replicada para os núcleos familiares no interior das casas, isto é, para cada fogueira e cada conjunto de pessoas que dormem de forma contígua e numa mesma casa. A replicação de uma estrutura de base triangular (como a do yãno) no interior da casa (hato nahi) é como um acoplamento em que, com a inserção de alguns elementos (postes, vigas e ripas) conectados com as peças propriamente estruturais da casa (estrutura essa chamada de yahi), se constitui algo como uma "casa" dentro da casa. Essa "casa", logo, corresponde à essa forma elementar de convivência promovida pelo yãno replicada no interior das casas do xapono.

O acoplamento se dá primeiramente através da inserção de um esteio simples à frente e entre dois dos esteios do fundo da casa, parte da estrutura principal da construção (aquela que suporta sua cobertura e faz o invólucro externo), conformando um triangulo (ou mais de um, dependendo do tamanho da casa e da família) dentro do espaço interno 
da casa. Assim como os esteios simples do yãno, estes são também feitos de apenas um pau, mas feito de madeira mais durável e, segundo os interlocutores do Marauiá, é chamado de totahima - mesmo termo que indica metaforicamente as "mulheres", sendo aquelas que penduram sua redes nesses postes que, segundo Lizot, podem referir-se também especificamente aos postes do fundo da casa (2004, p. 428). Acima desse esteio adicional, na ponta do triangulo, vigas oblíquas (yakiraorewë) travam a estrutura com a viga transversal da estrutura principal da casa e, como no yãno, são moduladas de acordo com o vão necessário para pendurar as redes. Sobre elas, enfim, uma ou várias peças transversais são adicionadas, não como um teto mas como um estrado, transformando a parte superior dessa estrutura em um jirau, utilizado para armazenar pertences dos mais diversos e sementes ou alimentos que, sobre o fogo, são postos para secar.

Essa estrutura interna, no entanto, não é chamada de yãno, como os acampamentos temporários, mas de ihira, termo traduzido para o português, justamente, como "jirau". O termo ihira não se resume apenas a essa construção no interior da morada, na qual amarram-se as redes e armazenam-se coisas diversas, mas indica, assim como na palavra em português (e de etimologia tupi), uma construção de madeira que serve para fins diversos e como uma espécie de plataforma, tanto para estocar coisas (ou corpos, no caso de um procedimento funerário que antecede a cremação) quanto para moquear carnes ou fazer um andaime, destinado à construção de uma casa, à uma passarela ou ponte sobre um curso d'água ou para cortar grandes árvores da floresta. $\mathrm{O}$ termo (ou o nome), ao que parece, deriva da raiz verbal ihirã- que, enquanto verbo transitivo ihirããt, indica a ação de "unir dois pontos para permitir a passagem de um ao outro" e, enquanto verbo de estado ihirãã, indica algo que está "unido", "em contato" e que "permite a passagem" (Lizot, 2004, p. 124).

No caso do ihira ("jirau") construído no interior das casas, é no centro desse estrado, alinhado com a fogueira doméstica, que é amarrada uma corda (natural ou sintética) e na ponta dessa se coloca um elemento chamado de yõpenama, que nada mais é que um galho em que, numa das pontas, desdobra-se como um cotovelo ou um gancho. Na dobra desse gancho é, então, onde se pendura a panela sobre o fogo, sendo que o nó corre no comprimento do galho e permite um ajuste fino da altura da panela em relação à chama da fogueira, ao mesmo tempo em 
que cria um distanciamento suficiente que impede que o fogo atinja e queime a corda. A tecnologia é simples e eficiente e, junto da disposição de triangular da estrutura ihira e das redes, com o fogo no centro, é o que constitui esse módulo habitável elementar. Apesar das diferenças na arquitetura das casas, diversas inclusive na escala de um mesmo xapono, quando vistas de dentro compartilham dessa mesma unidade, tal como notam vários autores. Para Luis Cocco, além da estrutura compartilhada entre os tapiris e o interior das casas, é nesse triângulo em que se define o espaço do habitar, un hogar nuclear (1972, p. 152); assim como para Lizot é esse arranjo de redes ao redor do fogo que configura uma "estrutura fundamental invariável" (1984, p. 59); e também para Reig que reconhece nessa estrutura um "elemento comum inalterado", a "unidade habitacional elementar", o "yãno elementar", um "princípio construtivo fundamental" e "onde o núcleo familiar básico é 'pendurado"' (2013, p. 184-7).

Antes da replicação da estrutura análoga ao yãno no interior das casas, é notável que no momento de se abrir uma nova clareira e construir um novo xapono, o primeiro círculo de casas que são feitas - de modo a permitir a mudança até que o grupo se estabeleça de forma mais estável no novo local (em paralelo ao trabalho nas roças) - possua um caráter mais efêmero e análogo ao do yãno. Estas primeiras casas nem sempre costumam ser nomeadas da mesma forma - isto é, como yãno -, embora a construção em si possa ser feita da mesma forma, assim como nos acampamentos, com um telhado de uma água (ou seja, com o fundo mais baixo que a ponta, abrindo-se para o meio do xapono e fechando-se para o lado externo do círculo), materiais menos duráveis e um processo construtivo mais ligeiro. Em outras situações um círculo de yãno, tal como a disposição das casas (yahi) em um xapono, pode ser construído durante saídas de wayumi nas quais uma grande parcela do grupo local passa um período prolongado habitando em uma clareira improvisada na floresta. Estes locais, inclusive, podem vir a se tornar lugares nos quais o grupo ou uma parcela cindida do grupo local pode vir a habitar no futuro, de forma menos temporária e em um xapono de fato.

Esses dados corroboram para o sentido do yãno como uma estrutura elementar, no sentido também de uma forma primária de construir e que antecede as casas "verdadeiras" (a yai) e mais duráveis (hiakawë) do xapono, na sua forma mais estável e menos temporária. Em períodos de mais mobilidade, por conta de conflitos guerreiros ou migrações sucessivas 


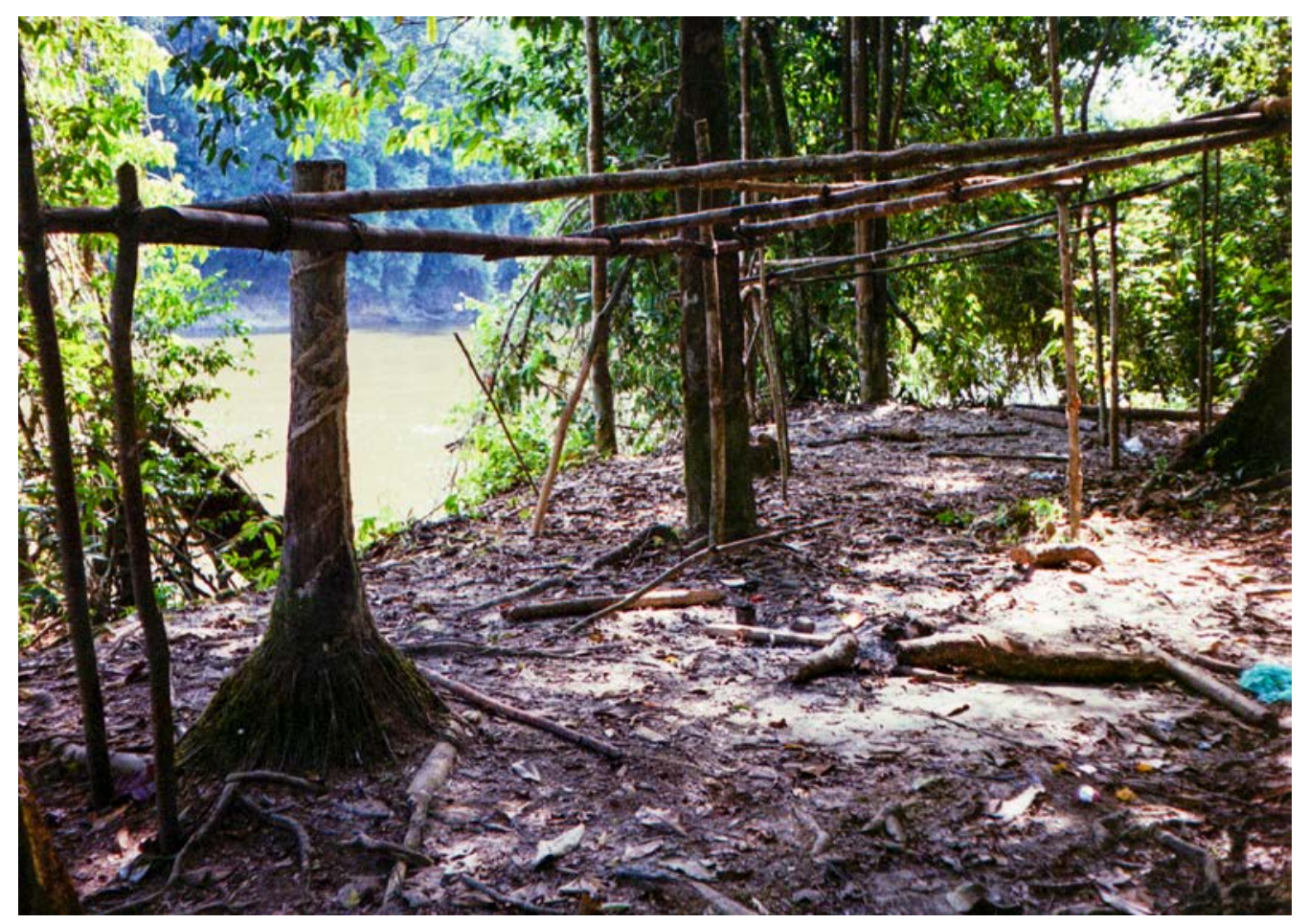

Fig. 24. Dois tapiris (yãno) recémabandonados em um acampamento na beira do Rio Marauiá (2020). 


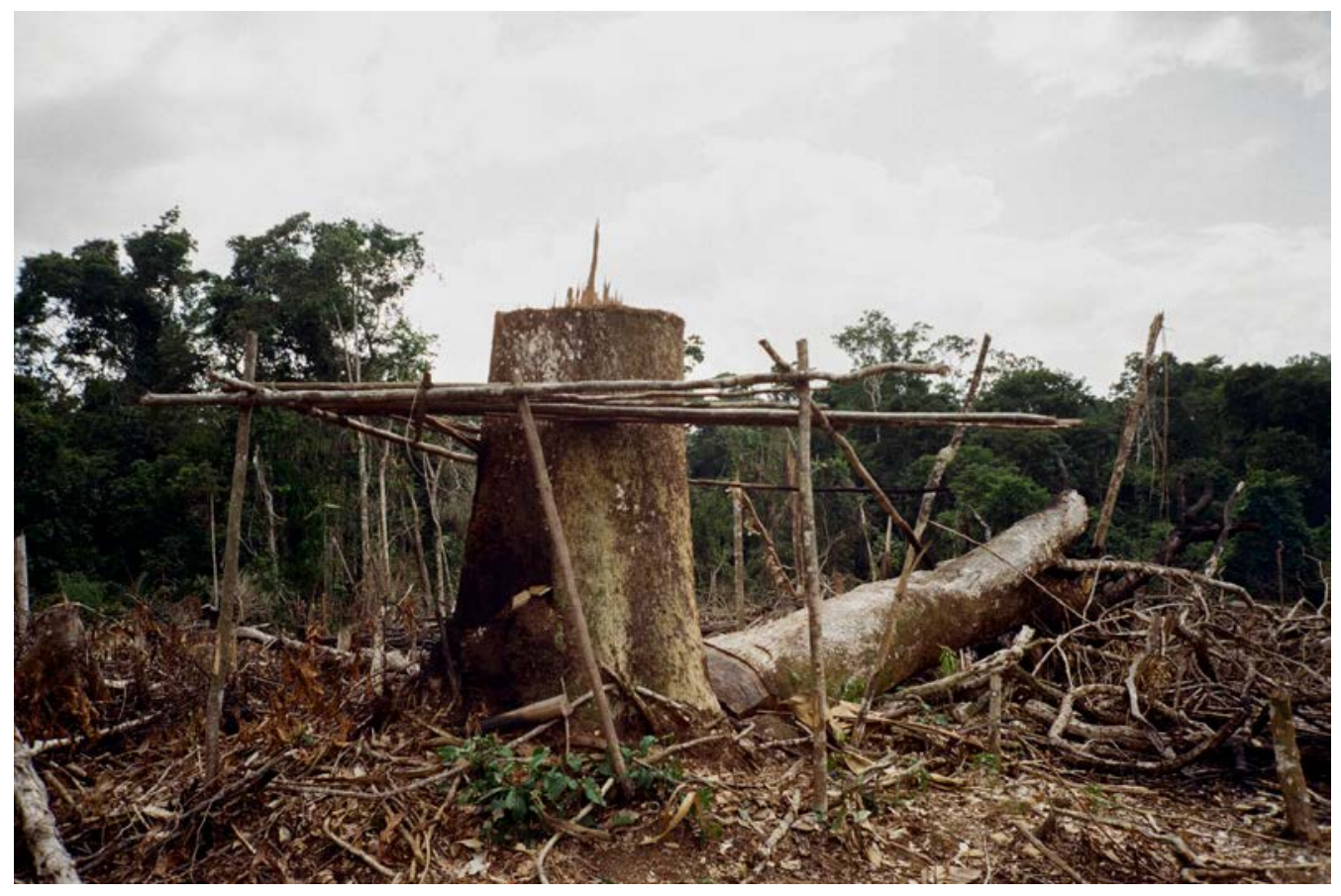

Fig. 25. Jirau (ihira) utilizada como um andaime para cortar uma grande árvore em uma roça próxima do xapono Pukima Beira (2019). 


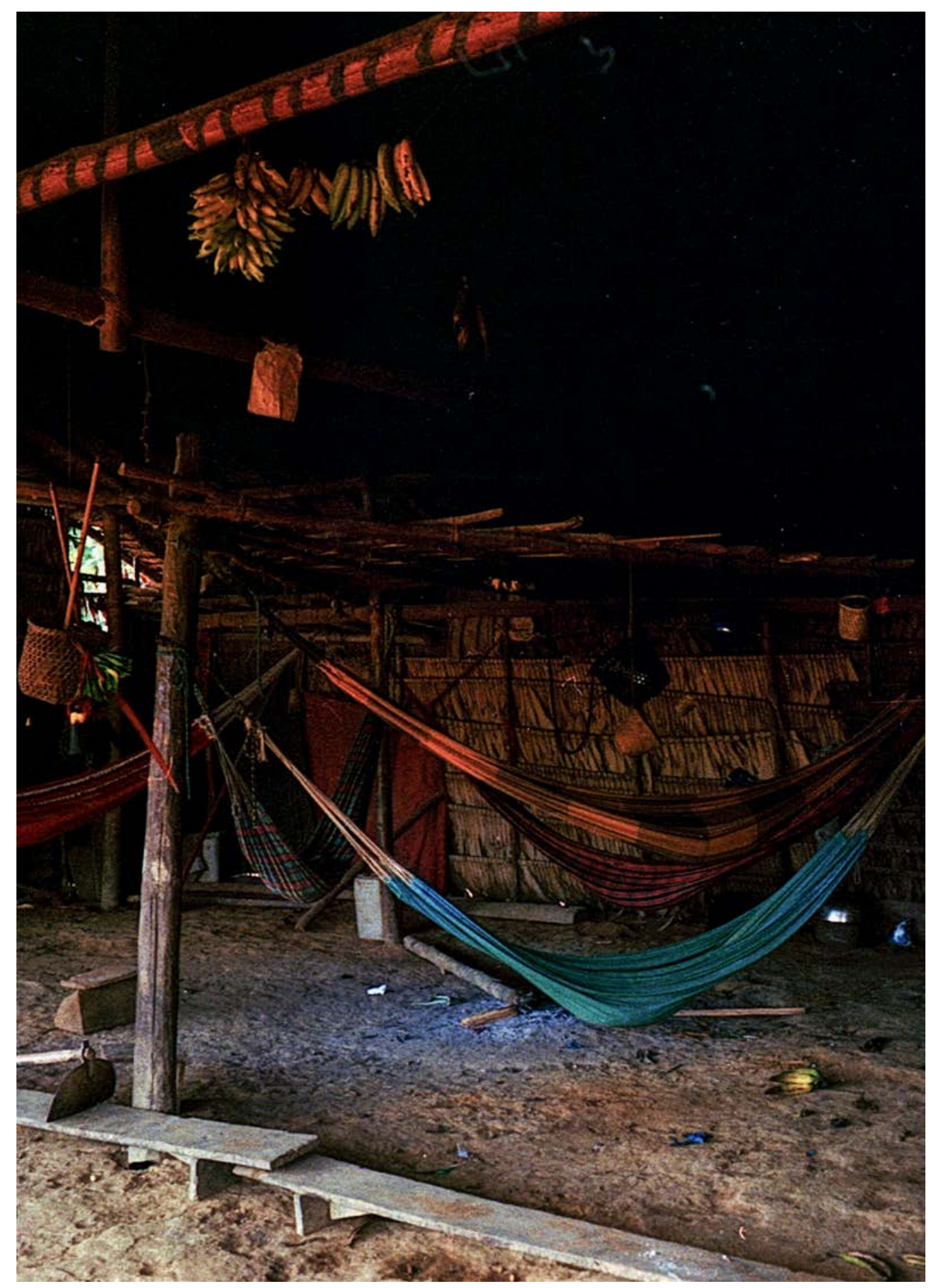

Fig. 26/27. Ihira ("jirau") com triângulo de redes em torno da fogueira na casa de Claudio, pajé do Pukima Cachoeira (2020). 


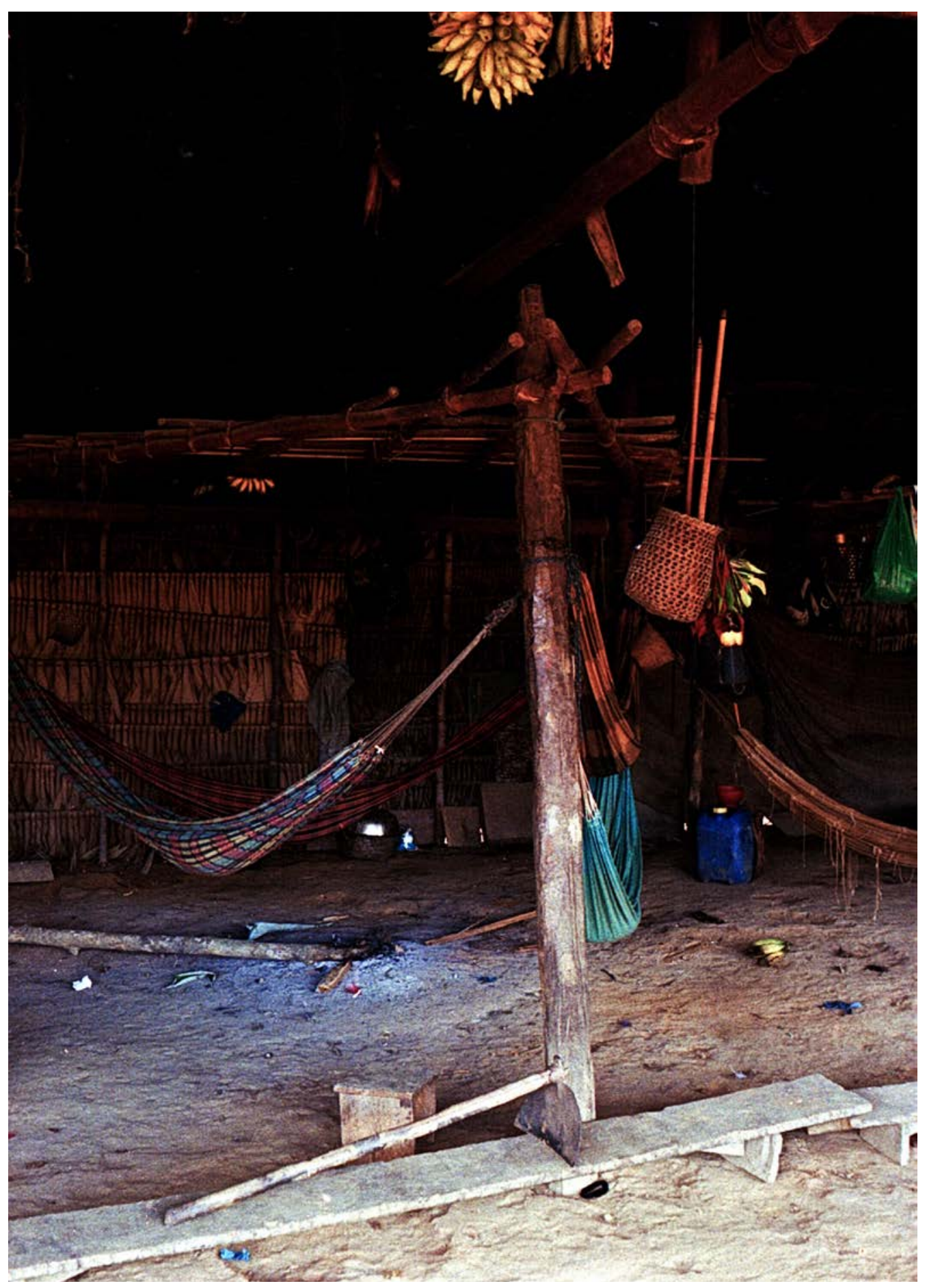


por exemplo, era comum que as casas fossem "tipo tapiri", como me relatou Francisco Pukimapiwëteri referindo-se ao tempo e à configuração dos xapono até o Hayanae, no período anterior ao contato e nos primórdios da ocupação da região do Rio Marauiá (provavelmente até a primeira metade do século XX). Ou assim como ocorreu recentemente, na última cisão de grupos locais do Marauiá (entre 2019 e 2010), os moradores do novo xapono Apuí saíram do xapono Bicho-Açu e retomaram um lugar que antigamente já haviam habitado, mas abriram uma nova clareira, mais próxima da margem do rio e, nesse novo local, fizeram rapidamente um primeiro xapono, como disseram-me suas lideranças, também "tipo tapiri", "como acampamento", para depois "fazer as casas de verdade". O "tipo tapiri", portanto, é aquele que permite maior agilidade nos processos construtivos e, no caso da passagem da instabilidade à estabilidade, com o fim ou uma trégua nos conflitos entre grupos locais por exemplo, estes podem ser aperfeiçoados ou, como costuma-se fazer, ser refeitos, operando a passagem de uma construção menos durável e mais temporária para uma mais durável e menos temporária.

Essa lógica é o que fundamenta também a breve hipótese de Cocco sobre a gênese da forma arquitetônica do xapono, como uma "evolução" de um círculo de tapiris (yãno) elementares em uma forma mais duradoura e mais estável, "semi-permanente" (1972, p. 150, nota 20), cujas casas são também organizadas em círculo, mas numa clareira mais ampla, de modo a comportar todo o hipotético grupo local. Não me parece exatamente praticável postular uma gênese petrificada ou uma evolução linear de tais formas, mas não deixa de ser notável a passagem lógica de uma série de construções "tipo tapiri", mais temporárias e apropriada para tempos de instabilidade, para construções mais duradouras e assim mais adequadas para momentos de maior estabilidade, o xapono, mantendo ou replicando no interior das moradas a forma elementar triangular do yãno. Assim, mais do que pensar em termos de uma suposta evolução linear que caminharia do simples (o acampamento) ao complexo (a aldeia ou, de outro ponto de vista, a cidade), poderíamos pensar nessa passagem do yãno ao xapono como uma certa evolução multidirecional. Como proposto por Lévi-Strauss (2013) no clássico ensaio "Raça e História" de 1952, tratar-se-ia, assim, de uma evolução técnica e morfológica que procede por transformações nãolineares orientadas pelos seus próprios critérios e não, ao contrário, rumo a uma forma previsível como o último degrau de uma escada que levaria 
exclusivamente à civilização ocidental - ou, seguindo o léxico arquitetônico do Médio Rio Negro, à casa de alvenaria e à cidade ribeirinha.

De outro ponto de vista, inspirado pelo mesmo autor, poderíamos compreender a passagem do yãno ao xapono como outro caso de uma transformação estrutural aplicada à arquitetura (Lévi-Strauss, 2001, p. 29). Nessa transformação, alteram-se os elementos através de diferentes operações: englobando-os, como a forma elementar do yãno replicada e acoplada no interior da casa (yahi); subtraindo-os, como a cobertura do yãno que dá lugar à um estrado sob a cobertura independente e mais durável da própria casa (yahi); densificando-os, ao substituir as madeiras menos resistentes do yãno temporário pelas madeiras mais duras e resistentes para o ihira; e também renomeando-os, de yãno ("tapiri") para ihira ("jirau"). Através de tais operações, no entanto, mantêm-se o sentido fundamental do módulo habitável. E a despeito das múltiplas variações da configuração das casas e do xapono (que veremos adiante), como nas virtualmente infinitas versões de um mito, há algo de ordem elementar e nuclear que se mantém, de forma análoga à estrutura dos mitos, como uma tríade de unidades constitutivas (Lévi-Strauss, 2008): o conjunto de parentes, (reunidos em) um triângulo de redes, (ao redor do) fogo. Seguindo a lógica estrutural, poderíamos pensar que cada um dos elementos contêm a natureza de uma relação, como as múltiplas formas de agenciar o fogo, mas ao serem colocados em relação entre si, como um "feixe de relações" (Lévi-Strauss, 2008, p. 227), adquirem um sentido fundamental. Esse sentido, ao que me parece, constitui-se nos dois jeitos essenciais de habitar (përio), "pendurando a rede" (yãai) no mato ou no xapono, no yãno ou no ihira.

Essa passagem do yãno ao xapono, contudo, poderia ainda ser lida no sentido de um contraste entre dois modos de viver - como proponho acima, no mato ou no xapono, no yãno ou no ihira. Isso, pois, através do contraste não se pressupõe a estabilidade como forma privilegiada - e tampouco estática ou absoluta - de ocupação, no sentido da forma do xapono ser mais complexa ou mais evoluída do que a transitória e primeira do yãno. Pelo contrário, evidencia uma dinâmica posicional e, assim como na prática do wayumi, uma estratégia política. Tal estratégia, como vimos, tem motivações variáveis em função dos regimes e dos potenciais conflitos sociopolíticos em questão - yanomami ou não-yanomami. Assim como na retomada e na atualização da estratégia do wayumi como enfrentamento 
à Covid-19 pelos Pukimapiwëteri do Alto Marauiá, pode-se notar que o contraste e a dinâmica posicional é também reversível, no sentido de que opera também no outro sentido, com um grupo mais estabilizado espacialmente mudando-se para outra configuração menos estável mais transitória. Através dessas variações multidirecionais, portanto, o que vemos é uma dinâmica latente - e, assim, passível de atualizações em diferentes momentos e em diferentes contextos - entre a agregação e desagregação, a estabilização e a mobilidade, a durabilidade e a transitoriedade. De forma que, para além da (ou em paralelo à) estratégia contextual, o que a prática de "sair para o mato" demonstra, através de tal dinâmica latente, é a necessidade estrutural de produção de diferença. Assim, entre os diferentes movimentos de concentração e dispersão, é através da variação e da contínua composição de diferenças - seja da forma de organização e moradia do grupo local, seja da própria forma arquitetônica de tais moradas, entre a aldeia e o mato - o que possibilita, anima e, de certa forma, mantém a vida social. 


\section{Casa-aldeia}

Os animais moravam em xapono; os quatis, as cutias e as antas, as queixadas, os coatás, os beija-flores, os passarinhos moravam em grupos como nós.

Fragmento de mito narrado por pajé Parahiteri (Ballester, 2017a, p. 51)

No tempo dos ancestrais no patapi, o tempo mítico da indistinção entre humanos e animais, todo mundo morava em xapono. Quatis, cutias, antas, queixadas, coatás, beija-flores e passarinhos (Ballester, 2017a, p. 51), mas não só. Alguns xapono eram em cima das árvores, como o do povo Esquilo, Wayapaxiri (Ballester, 2017b, p. 74); outros debaixo do rio, como o do povo das águas, Yawari (Kopenawa; Albert, 2015, p. 93/616, nota 8). De diferentes formas, todos tinham e todos moravam em xapono. Não há, entretanto, um mito yanomami específico sobre a origem ou sobre a forma do xapono. Entre os Ye'kwana, por exemplo, conta-se que o conhecimento de como construir malocas foi adquirido com o povo Japu, koli (Wilbert; Simoneau, 1990, p. 213, M118), pássaros que, assim como os japins, tecem seus ninhos pendurados nos galhos em grandes comunidades aéreas-arbóreas. Em outras narrativas ye'kwana, contam ainda que foi o demiurgo Wanadi que construiu a primeira maloca (Attawanadi), visível atualmente na forma de uma montanha cônica no centro do território ye'kwana, e, ao mesmo tempo, sua contraparte invisível, o duplo das malocas (atta) atuais (Rivière, 1995, p. 194).

Diferente dos Ye'kwana, os mitos yanomami não versam sobre um xapono primeiro ou prototípico em particular, mas, ao contrário, demonstram uma profusão de xapono possíveis e, indiretamente, indicam que o xapono é o que constitui o idioma da coletividade, o pano de fundo da socialidade vivente. Como se, num certo sentido, todos os mitos fossem sobre ele, ainda que nenhum seja propriamente dele. No entanto, se no tempo mítico o xapono enquanto idioma da coletividade era partilhado de forma comum entre as espécies ancestrais (yarori), foi com a transformação e a distinção entre animais (yaro pë) e humanos que os últimos passaram a ser caracterizados de forma específica ao seu modo de viver em casas, 
no xapono. Segundo Davi Kopenawa: "Os animais nos consideram seus semelhantes que moram em casas, ao passo que eles se veem gente da floresta. Por isso dizem de nós que somos "humanos caça moradores de casa!' [em Yanomam, "yanomae thë pë yaro yahi thëri thë pë!", em oposição à "urihi thëri yaro pë", "animais habitantes da floresta"]" (Kopenawa; Albert, 2015, p. 473/679, nota 14). Nesse sentido, são as casas (yahi), que caracterizam a natureza da humanidade atual e, também, fazem do xapono, em suas múltiplas configurações, mais do que um conjunção de moradas, o idioma da coletividade e da socialidade propriamente humana e, com isso, yanomami. Assim, para além de um modelo prototípico das moradas dos "humanos caça moradores de casa", o que há é um idioma da coletividade compartilhado, não um modelo formal estanque, mas variações de diferentes casas (yahi) e xapono, como as múltiplas variações de um mesmo mito. Vejamos.

Antigamente "os xapono eram todos tipo tapiri", como me relatou Francisco Pukimapiwëteri, e "os antigos não sabiam fazer as casas como as de hoje". Francisco, que é irmão do përiomí ("liderança") Adriano e jovem pajé do Pukima Cachoeira, se referia assim não ao tempo mítico mas ao "tempo do Hayanae", quando os antigos grupos de origem Karawëtari já estavam situados na região do Rio Marauiá, no período anterior ao contato regular com os Poowëteri (o "povo do machado", os "brancos"). Como vimos no capítulo anterior, as casas antigas mas também as atuais de "tipo tapiri" - como os yãno com o telhado de apenas uma água -, indicam períodos de mais instabilidade e de recentes ou sucessivas mudanças, próprios, portanto, do "tempo do Hayanae". Assim, em sua narrativa, o xapono Hayanae teria sido um marco no qual (em algum momento da segunda metade do século $\mathrm{XX}$ ) os antigos construíram as primeiras duas casas "como as de hoje", a saber, com telhado de duas águas - isto é, com dois lados inclinados e divididos ao topo por uma cumeeira, um apontando para os fundos e outro para frente da casa.

Conforme Francisco, as casas antigas "tipo tapiri" - as quais Luis Cocco chama de "yahi clássico" e "yahi típico" (1972, p. 142/146) tinham muitos problemas com temporais e ventanias, que levantavam os telhados e causavam uma certa destruição das palhas da cobertura das moradas. Ainda antes do contato regular com os Poowëteri, segundo meu interlocutor, os Hayanaeteri (o "povo do xapono Hayanae") haviam feito uma visita aos parentes da região do Marari e lá tomaram conhecimento 


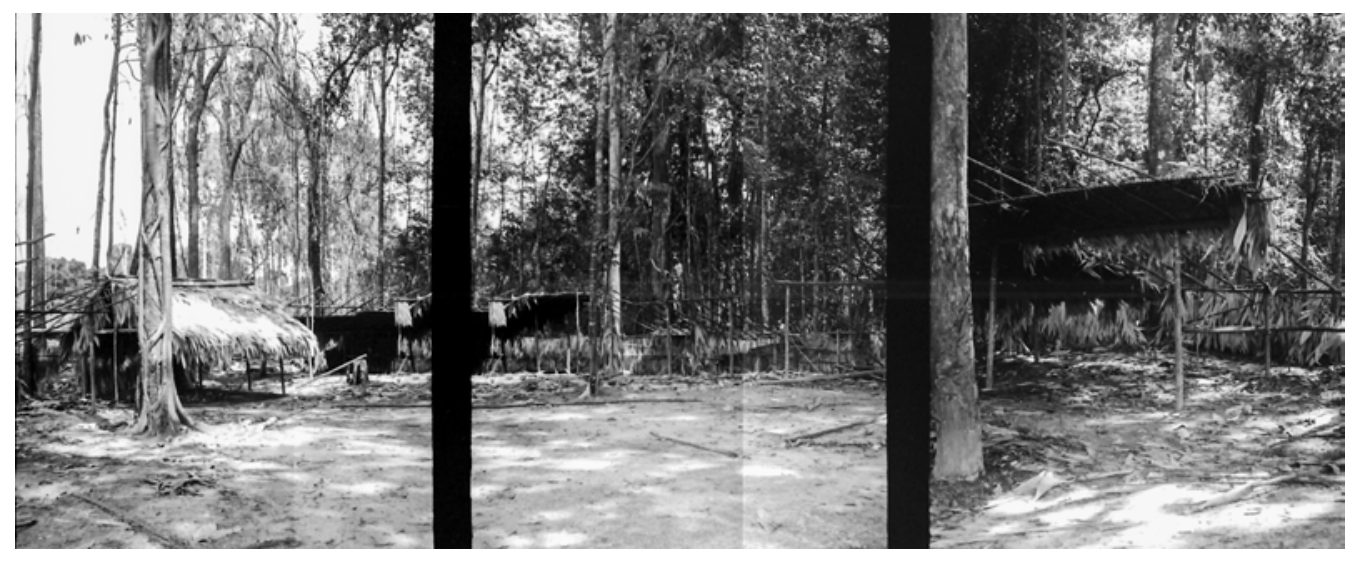

Fig. 28. Colagem com fotos de um pequeno xapono temporário e abandonado, com as casas "tipo tapiri" construídas na beira do Baixo Rio Marauiá (2016). Este xapono serviu como a primeira morada dos habitantes do Serrinha que, pouco tempo antes, haviam aberto outro xapono maior e mais estável ao lado, na clareira que se vê à esquerda, pouco mais longe da beira do rio. 
dos missionários evangélicos da Missão Novas Tribos do Brasil, onde estes estabeleceram o Posto Marari em 1968 e até hoje lá permanecem. Como são grupos historicamente relacionados (conforme vimos no capítulo "Sangue da Lua"), a visita foi guiada pelo objetivo de estabelecer trocas e junto disso tomaram conhecimento dessa outra técnica de construção das casas, de modo que a troca se deu também de outras maneiras. $\mathrm{O}$ xapono do Hayanae, portanto, teria sido o primeiro a ter casas desse tipo na região do Marauiá - duas casas, como especificou Francisco, de dois patapata pë ("velhos") já falecidos.

O relato de Francisco Pukimapiwëteri surgiu a partir de uma questão que eu havia colocado sobre a existência ou não de "casas coletivas", "casas comunais" ou "malocas" no "tempo do Hayanae". Minha referência, com isso, eram as construções que foram de alguma forma cristalizadas como uma forma essencial ou prototípica da arquitetura yanomami: um único teto contínuo, como um anel ou um cone truncado, circundando a borda externa de um limpo terreiro, tal como o amplamente conhecido yano (na língua Yanomam esse é o termo equivalente a xapono) de Watoriki onde mora o líder Davi Kopenawa (cf. Albert; Milliken, 1997). A esse tipo questão, os Yanomami do Marauiá, além do próprio Francisco, costumam responder com assertividade: "nós nunca construímos assim", "isso é coisa do povo de Roraima" - sendo o "povo de Roraima" (waika) o equivalente à uma marca opositiva de alteridade (waika/xamatari), conforme vimos no capítulo "Sangue da Lua". A questão, no entanto, configura uma espécie de falso problema, pois, como veremos, a ideia de ter ou não "casa coletiva" pode ser equívoca. Já a suposta forma essencial, formulação mais imprecisa que equívoca, acaba por eclipsar uma miríade de variações possíveis da forma do xapono, tal como abordaremos ao longo do desenvolvimento deste capítulo, a partir de descrições etnográficas dos xapono dos Pukimapiwëteri do Alto Marauiá e de uma reflexão sobre o que constitui, afinal, um xapono.

Antes vale apontar uma síntese dessa perspectiva essencialista ou, como como aponta Alejandro Reig, "fetichista" (2013, p. 155), que ressalta de modo expressivo num artigo de Graziano Gasparini e Luise Margolies (2004) intitulado "La Vivienda Colectiva de los Yanomami". Segundo esses autores, num trecho destacado também por Reig (2013, p. 155): o "shapono [m.q. xapono] permanece imutável e indiferente a qualquer tipo de influência externa" e, apesar de que "nas últimas décadas os Yanomami 
assimilaram formas e técnicas construtivas diferentes [...] é evidente que quando existe a intenção de construir o shapono que culturalmente os identifica, se descartam e ignoram as influências modificadoras. É como um ato de reafirmação cultural coletiva [...]" que "não renuncia a ancestral concepção cultural imutável” (Gasparini; Margolies, 2004, p. 103-104). O pressuposto essencialista de uma tal "ancestral concepção cultural imutável" (Gasparini; Margolies, 2004, p. 104) é algo totalmente estranho aos Yanomami e à construção do xapono, de modo que nesse processo não só não se "descartam e ignoram as influências modificadoras" (Gasparini; Margolies, 2004, p. 104), como, ao contrário, estas são incorporadas, adaptadas e transformadas. Um exemplo marcante dessa dinâmica natureza das técnicas construtivas yanomami é, justamente, o caso do yano [m.q. xapono] de Watoriki, cuja construção foi detalhadamente descrita por Bruce Albert e William Milliken (1997).

Em suma, o yano de Watoriki (situado entre a bacia do Rio Catrimani e do Demini), como apontado acima, é um exemplo icônico do equívoco possível em torno da suposta forma essencial ou prototípica de construir e habitar entre os Yanomami. Icônico, pois sua estrutura de forma anelar e contínua, com aproximadamente oitenta metros de diâmetro, aos pés do paredão rochoso da Montanha do Vento (serra com o mesmo nome Watoriki) é, aos nosso olhos, de fato monumental. A isso, soma-se a crescente exposição que as imagens desta morada atingiram nas últimas décadas, acompanhando a proeminência política de Davi Kopenawa, constituindo uma certa imagem prototípica não só da arquitetura yanomami como do "povo Yanomami". Contudo, como Albert e Milliken ressaltam, anteriormente à construção de Watoriki em 1993, as casas habitadas por esse grupo consistiam em agrupamentos, ao redor de uma mesma clareira circular, de casas com telhados de apenas uma água (1997, p. 227) - as tais casas "tipo tapiri", como dizia o interlocutor Pukimapiwëteri, quem às vistas dos Watoriki thëri pë ("o povo da Montanha do Vento") é considerado xamatari. No entanto, foi justamente com grupos xamatari de um afluente do Rio Demini (próximos também de uma missão da Novas Tribos do Brasil) que "o povo da Montanha do Vento" conta ter aprendido e "emprestado" a técnica de construir os telhados com duas águas, adicionando à forma "tradicional" uma aba voltada ao interior do yano, com a ressaltada vantagem de sombrear o interior das casas no decorrer do dia (Albert; Milliken, 1997, p. 227). Além 
disso, a técnica de cobertura com a fixação das palhas de ubim (Geonoma baculifera) em ripas de paxiúba (Socratea exorrhiza) foi também adquirida a partir de contatos com trabalhadores do SPI (Serviço de Proteção aos Índios) nos anos 1940, dentre eles indígenas de outros grupos, como os Tukano. Desde 1993, portanto, os moradores do yano vêm refazendo a estrutura da cobertura, trocando as palhas e reforçando-a sempre que necessário. Como o estudo de Albert e Milliken aponta, além da inovação técnica e morfológica, a determinação das espécies vegetais utilizadas na construção dessa morada também foi adaptada. Assim, foram priorizadas as espécies mais duráveis e maios resistentes de forma à alinharem-se ao intuito do grupo que afirmava "não ter planos de mudar-se novamente em um futuro próximo" (1997, p. 227). Como concluem os autores: "Embora a tradição obviamente tenha um papel importante na escolha de materiais para a construção de casas, o oportunismo também é inevitavelmente um fator importante" (Albert; Milliken, 1997, p. 228).

Com esse breve exemplo introdutório de Watoriki torna-se nítido que a questão do xapono excede o falso problema da "ancestral concepção cultural imutável" (Gasparini; Margolies, 2004, p. 104). O exemplo de Watoriki demonstra como as formas supostamente tidas como essenciais ou prototípicas podem ser derivações de arranjos mais complexos, combinando aprendizados, circunstâncias, técnicas, materiais e estratégias diversas. No entanto, a imagem do yano de Watoriki, com seu icônico teto contínuo (assim como outras configurações possíveis do xapono, notadas sobretudo na região central do território yanomami), extrapola o detalhe da cobertura de duas águas - como vimos, uma atualização do "tipo tapiri" tradicional - e permanece num certo imaginário como um modelo "tradicional" de "casa coletiva" yanomami. A ideia de "casa coletiva" - esta que os Yanomami do Marauiá costumam dizer que "é coisa dos Yanomami de Roraima" -, entretanto, precisa ser melhor situada. E assim como exemplo de Watoriki descrito por Albert e Milliken, os xapono dos Pukimapiwëteri do Alto Marauiá apresentam variações interessantes e produtivas para a reflexão em questão. Mas se os Yanomami do Marauiá nunca construíram assim e isso é coisa "do povo de lá", como construíam e como constroem então?

Através dos registros pioneiros da "expedição etnológica" realizada entre 1964 e 1968 por Gottfried Polykrates (1969), são notáveis algumas das sutilezas sobre a ideia da "casa coletiva", assim como dos detalhes das 
antigas casas "tipo tapiri" e também da configuração do xapono naquele período, em particular, do antigo xapono Pukima (ou Pukima Centro), derivado do Hayanae e visitado em 1968 por Polykrates. Como diz o autor: Uma aldeia [dorf] Yanonámi oferece uma visão incomum para quem a vê pela primeira vez. Especialmente quando você o vê de uma colina como eu. Você procura em vão por casas ou cabanas. Em vez disso, toda a vila consiste em um enorme telhado coberto [...] (Polykrates, 1969, p. 36).

No entanto, assinala que "o teto coberto é interrompido quatro vezes, para que você possa facilmente entrar na praça da aldeia do lado de fora e entrar nas habitações, o que, de outra forma, só seria possível se você rastejasse" (Polykrates, 1969, p. 38).

Seguindo com as notações de Polykrates (1969, p. cap. V-VII), o antigo xapono dos Pukimapiwëteri era composto por três grandes casas, contornando de forma mais ou menos circular o terreiro central com um telhado de uma só água, "tipo tapiri", de modo que aos fundos a altura da cobertura e do fechamento não ultrapassava um metro e à frente, abrindo-se ao meio do xapono (xapono heha), atingia por volta de quatro metros. Além dessas três casas, em um dos intervalos, o autor registrou também a construção de um pequeno abrigo de reclusão de mulheres que passam pela primeira menstruação, cuja cobertura de duas águas chegam até o chão, com uma pequena entrada lateral e densamente cerrado pelo fechamento de palha - no Marauiá, atualmente, estes abrigos costumam ser construídos no interior das casas, criando uma compartimentação com folhas de açaí ou quaisquer outros materiais que se encontrem à disposição, como telas mosquiteiras, tecidos, redes e lonas plásticas. A separação em três casas - dentre a população registrada pelo autor de 157 pessoas -, ao que poderia se supor, talvez correspondesse aproximadamente aos distintos grupos familiares que, no decorrer dos anos e a partir de determinados conflitos (seguindo o histórico traçado no capítulo "Sangue da Lua"), se dividiram do xapono Pukima em outros xapono ao longo da bacia do Marauiá: respectivamente, o grupo do Raita, do Pukima Beira e do Pukima Cachoeira (que depois também separou-se gerando o Tomoropiwëi).

Nesse sentido, como ressalta o próprio autor, se "toda a vila consiste em um enorme telhado coberto" mas "o teto coberto é interrompido quatro vezes" (Polykrates, 1969, p. 36/38), depreende-se daí que a "casa coletiva" não é sempre totalmente "coletiva", no sentido de uma unidade genérica, 


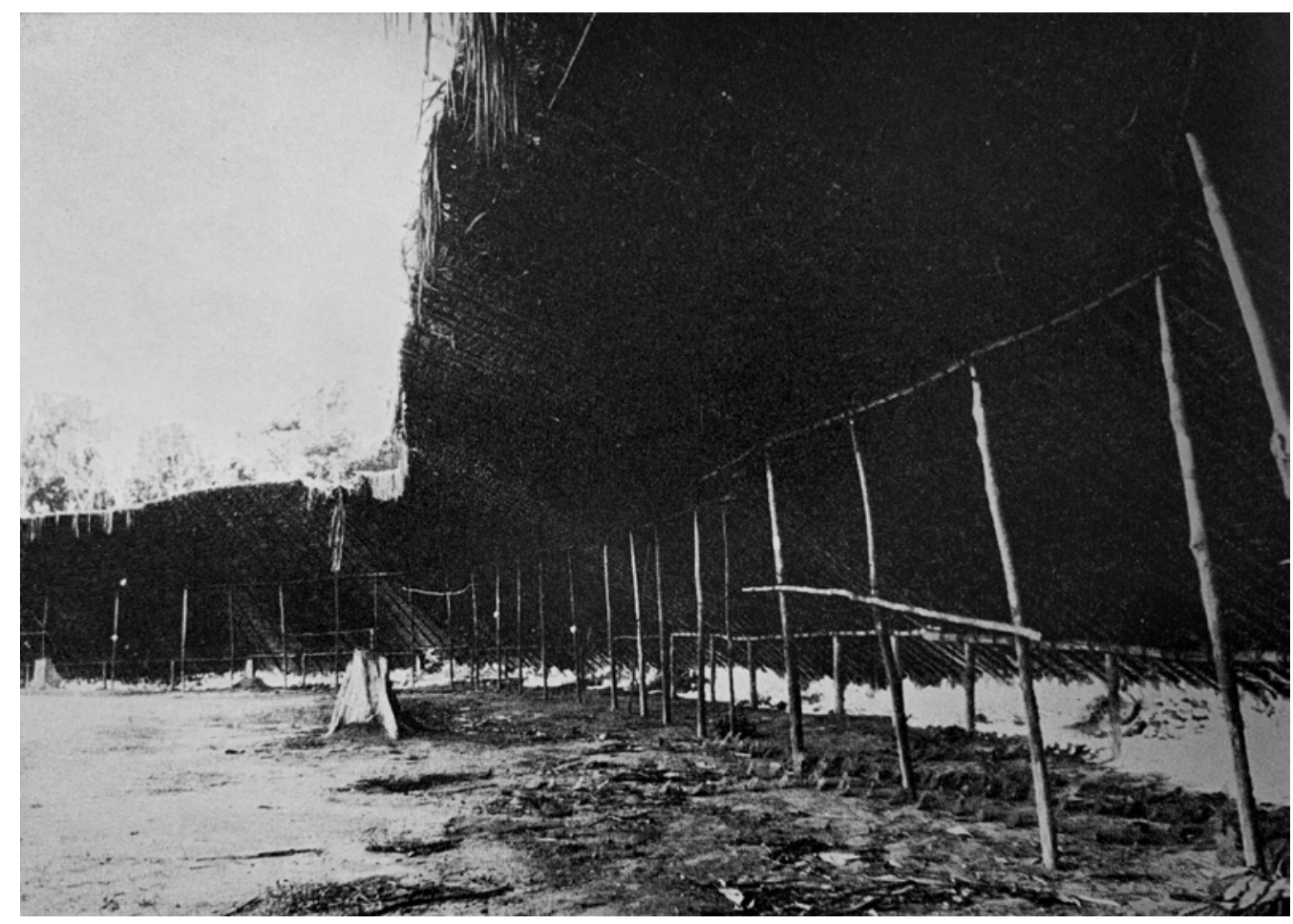

Fig. 29-31. Fotos e desenho de Gottfried Polykrates (1969). Acima, um xapono Xamatawëteri no Rio Marauiá na década de 1960. Como explica o autor na legenda da foto, a casa-aldeia "foi encontrada abandonada porque seus habitantes estavam fazendo uma de suas excursões de caça", provavelmente de wayumi. $\mathrm{Na}$ página seguinte, acima, registro do xapono Pukima, ao fundo da imagem, um grande abrigo de reclusão das mulheres que passam pela primeira menstruação, e à frente, uma antiga casa (yahi) com telhado e apenas uma água, "tipo tapiri". Abaixo, planta e corte transversal da estrutura do antigo xapono Pukima, com três grandes casas e o abrigo de reclusão. 

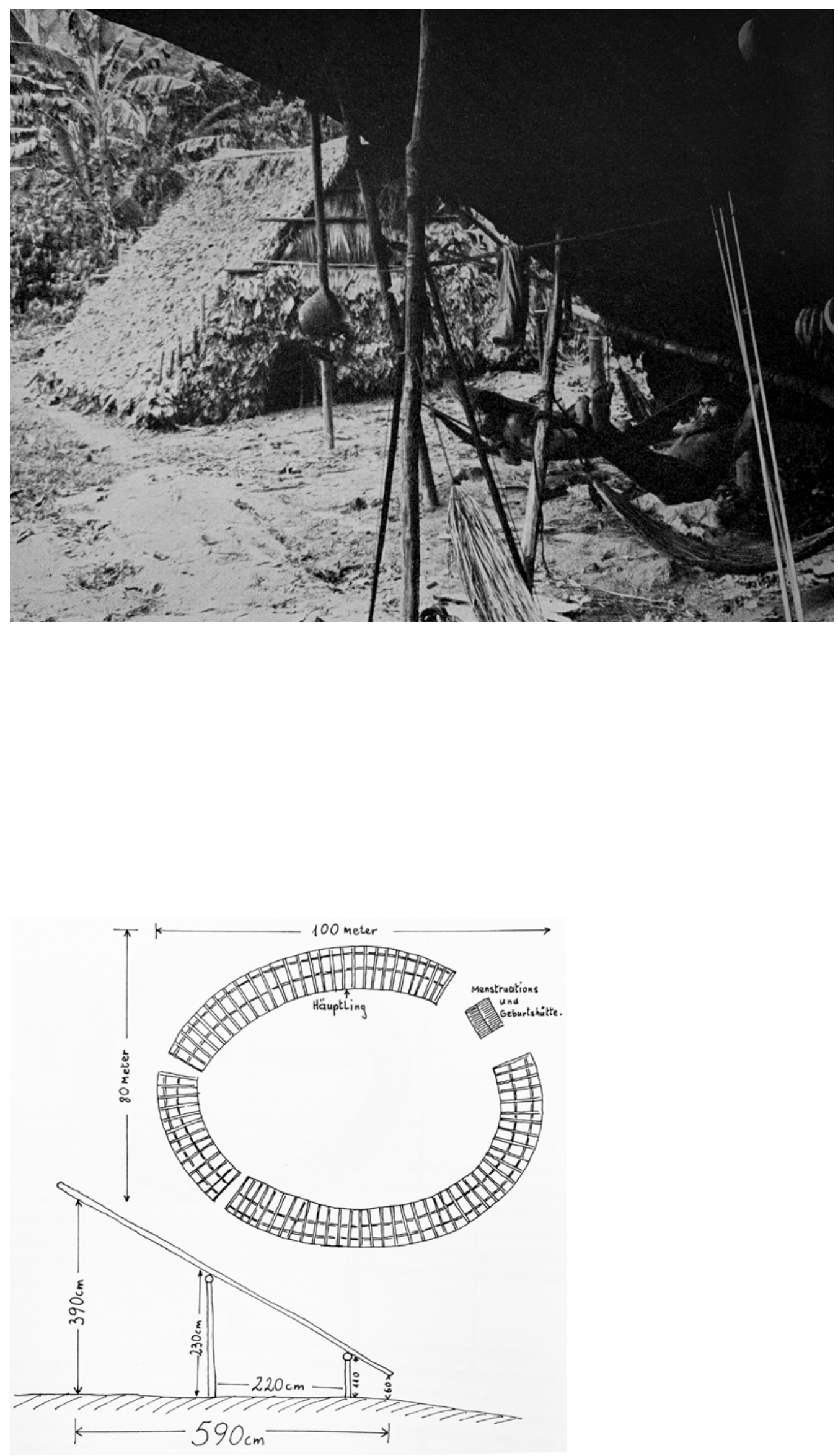
assim como não é necessariamente composta de uma só estrutura. Ao contrário, é o resultado de uma conjunção instável e efêmera de distintas grandes casas de grupos familiares reunidos em torno de um mesmo vazio central. Através dessa configuração - resumida aqui com o caso do antigo Pukima, mas totalmente múltipla já que não há sequer uma casa igual à outra - as "casas coletivas" yanomami complexificam esta noção, assim como a de "maloca", em muito presente na literatura antropológica. No geral, o que se refere por esses dois termos são estruturas únicas e comunais nas quais todo o grupo local habita sob um mesmo teto, como as malocas (antigas, atuais ou atualizadas) dos Ye'kwana, Yukuna, Tukano, Barasana ou Witoto, dentre vários outros povos das terras baixas sul-americanas - estes anteriormente citados correspondem, contudo, aos exemplos analisados por Stephen Hugh-Jones (1985) em um artigo sobre o assunto.

Segundo a hipótese de Luis Cocco - tal como a da "gênese" do xapono a partir de uma conjunção de vários yãno, como abordado no capítulo anterior - é possível pensarmos nestas configurações amplas e parcialmente dispersas da "maloca" yanomami como uma variação expandida das malocas cônicas que se encontram sobretudo na região central do território yanomami, na Serra Parima. Em parte similares às malocas Ye'kwana (cf. Guss, 1990), estas possuem formas cônicas (ou cilindro-cônicas) e, frequentemente, uma pequena abertura no topo, como versões reduzidas dos amplos vazios centrais dos xapono, o xapono heha (que falaremos em detalhes mais adiante). Em seu interior, acessível por uma ou mais pequenas portas, comportam todo o grupo local, de modo que correspondem à grupos com população significativamente menor - e diferente dos populosos e amplos xapono tal como o "mítico" Hayanae, onde "se você sair hoje, não chega não [do outro lado], tem que dormir no caminho" (Miranda, 2020, p. 52). Essa tipologia cônica, mais próxima das "clássicas" malocas (Ye’kwana, por exemplo), pode também ser nomeada na língua Yanomami por xapono, muito embora no Marauiá costumem se referir a ela, num misto com a língua portuguesa, como "xaponinho", o que reforça o provável sentido do xapono como uma variação expandida dessa tipologia menor. Com a possível variação e expansão das formas cônicas às formas mais dispersas de casas "tipo tapiri", entretanto, não se perde um certo sentido do "coletivo". Ao contrário, transforma-o. E como veremos no capítulo seguinte, se aquilo que constitui o modo essencial de habitar o xapono é a ideia de "viver junto" (yaiprou), este não se resume, 
necessariamente, ao viver junto sob um mesmo teto.

Na descrição que Cocco apresenta sobre as casas yanomami do Alto Orinoco pode-se também depreender esse sentido comunal mais complexo do xapono:

O círculo de telhados dá a impressão de uma imensa casa comunal, especialmente se for uma aldeia pequena, e é chamada xapono, uma palavra que podemos traduzir pelo termo crioulo de maloca. Visto de cima, ele nos lembra a tonsura típica que os Yanomamos usam em seus crânios [trata-se do corte redondo dos cabelos no topo da cabeça, também chamado de xapono] (1972, p. 142).

E do ponto de vista morfológico, segundo Cocco, é "como se [o teto das casas de "tipo tapiri"] quisesse convergir para o vértice de um cone semiimaginário, a verdadeira figura geométrica do conjunto habitacional Yanomamo" (1972, p. 144). No entanto, "o teto de cada casa pode estar unido ao das adjacentes, mas geralmente dista ao menos um metro e, às vezes, vários metros» (Cocco, 1972, p. 144). Embora em alguns casos, complementando a ressalva de Cocco, tal como documentado no xapono do povo Moxihatëtëa em isolamento voluntário, os tetos das casas "tipo tapiri" possam também se sobrepor, dando a ideia para quem a vê de cima (como no registro aerofotográfico de setembro de 2016, cf. Funai, 2016) de uma construção única, uma só "maloca". Ou ainda, como é o caso em alguns segmentos dos xapono do Marauiá, as casas atuais com telhado de duas águas - são implantadas de modo contíguo umas às outras, formando também um aparente conjunto único, apesar de possíveis fechamentos laterais.

A partir dessas descrições, a questão que parece se delinear com mais clareza é que a ideia de "casa coletiva" ou "maloca" como uma construção necessariamente única, a partir da suposta oposição entre casas coletivas e não-coletivas (unifamiliares ou com famílias expandidas, tal como o caso do antigo Pukima), simplesmente não dá conta dos inúmeros modos pelos quais os xapono se configuram. Algo análogo foi notado por Peter Rivière (1995, p. 193) ao comentar o caso dos Ye'kwana, povo "tradicionalmente" construtor de malocas, inclusive, tal como mencionado acima. Segundo a síntese desse autor, o que se nota a partir do abandono da forma tradicional da "casa-única [single-house]" pela "casa-múltipla [multi-house]" é que ambas não são "fundamentalmente" diferentes, mas "variações umas das outras" (Rivière, 1995, p. 190/193). Assim, mais do que uma oposição estanque entre separação ou unificação 
das moradas onde habitam os grupos locais, proponho de pensarmos nas distintas configurações possíveis dos xapono, tal como propõe Reig (2013, p. 243), como processos dinâmicos que concatenam motivações diversas, entre as relações de parentesco e a dialética entre cooperação e autonomia, por exemplo. Assim, dentre as complexas dinâmicas de agregação e desagregação que regem o ato e o processo de "viver junto" (yaiprou), a morfologia da "casa coletiva" - o que Reig classifica como "the roundhouse village" - deve ser pensada como "um de seus momentos", isto é, uma das configurações possíveis, dentro de certo marco social, espacial e temporal, "tão expressiva da ordem social como o padrão das casas separadas" (Reig, 2013, p. 243).

Nesse sentido, mais do que "casa coletiva", "casa comunal" ou "maloca", penso que a tradução de xapono (ou yano, em Yanomam) mais produtiva e atenta a essa complexidade inerente às variações morfológicas é aquela seguida por Bruce Albert em diferentes trabalhos: "casa-aldeia". Casa-aldeia, portanto, permite-nos usar a linguagem que nos pertence para criar, de forma compósita, um contraste interno a ela mesma, bem como propõe Marilyn Strathern (2013a). Assim, a proposta de tradução tensiona a oposição entre unificação e separação que, da perspectiva dos Yanomami do Marauiá, aponta para outro falso problema. Isso, pois, ao mesmo tempo em que constroem atualmente casas "separadas" (como veremos na descrição a seguir), em diferentes contextos pode-se se escutar afirmações como essa que ouvi de Mauro Pukimapiwëteri, em português: "Nossa casa é diferente, ela é coletiva, redonda". O contexto da fala de Mauro evidencia que ele assim buscava criar um contraste com os modos não-yanomami de habitar, muito embora em nosso diálogo este interlocutor reforçou a descrição do xapono como algo coletivo, para além do contraste e como algo que o caracteriza. Especificamente, Mauro se referia ao xapono Pukima Cachoeira, onde ele habita e, nota-se, não é composto por um único teto. Mesmo assim, em sua fala a tradução mobilizada para o termo xapono é "casa", no singular, muito embora em outros momentos e com outros interlocutores (e com o mesmo, inclusive), xapono pode também ser traduzido para o português como "aldeia". O sentido de um, no entanto, é complementar ao do outro, de modo que o xapono não deixa de ser "coletivo" pela separação em casas (yahi) - como é, também, na tal "roundhouse village", onde cada família possui seu núcleo familiar discernido pelos módulos estruturais que posteriormente podem 
ser unidos sob uma mesma cobertura. Assim, o sentido do "coletivo", tal como mobilizado por Mauro, se solta do lastro de uma aparência "coletivista" dada pela possível união dos tetos dos grupos familiares e aponta para um modo próprio de sociabilidade, configurando assim, um modo específico de habitar - "diferente", como disse Mauro. Dessa forma, para além da unificação ou separação, tal perspectiva permite-nos pensar a casa-aldeia no todo: da borda da clareira ocupada pelas casas, em suas distintas configurações, ao meio do terreiro, o vazio mais ou menos circular que une em torno de si, ao menos por um momento, um determinado grupo local em um lugar específico; uma mesma casa, uma mesma aldeia: casa-aldeia.

Voltaremos no capítulo seguinte ("Viver junto") à essa forma própria de sociabilidade expressa, espacialmente, pela configuração do xapono. Por ora, concentro-me aqui nas configurações morfológicas do xapono. Assim, mais do que a oposição entre coletivo e individual (ou unifamiliar), o que permite analisar as distintas configurações dos xapono, ao meu ver, é a escala entre durabilidade e efemeridade - ou, na língua Yanomami, hiakawë e ëpëhëwë, verbos de estado com o sentido, respectivamente, de "duro" e "frágil", "forte" e "fraco". Tal proposta, no entanto, atualiza uma ideia antiga de Cocco:

Existe uma escala de perfeição-imperfeição que torna possível discriminar claramente o xapono dos acampamentos de tapiris. Uma coisa é certa: ao abrandar o expansionismo [como os ciclos de migrações antigos, cf. capítulo "Sangue da Lua"] e o seminomadismo [ou seja, ao reduzir a mobilidade, por exemplo, induzida pelos antigos conflitos guerreiros] yanomamo, estes índios constroem moradas cada vez mais sólidas e mais funcionais (1972, p. 145).

Mas ao invés da perfeição e de seu revés, critérios de valor cristão que escapam às formulações éticas e estéticas yanomami (lembrando que Cocco era missionário salesiano), penso que a questão da durabilidade - estimulada pelo intuito de permanecer mais tempo em determinado local e condicionado pelas circunstâncias das relações sociopolíticas do momento - permite compreender de forma mais precisa o que constitui um xapono e, de forma complementar (como abordamos no capítulo "Tapiri"), a dinâmica posicional que leva à passagem do círculos de tapiris (yãno), mais efêmeros e sujeitos à regimes de mobilidade mais intensos, para as distintas configurações do xapono, mais duráveis e portanto mais 
sólidos e mais resistentes (ver proposição similar em Reig, 2013, p. 163).

Comisso, aprende-semelhor mençãoqueFrancisco Pukimapiwëteri faz às moradas antigas, "tipo tapiri", associando essas não a uma forma essencial ou prototípica do xapono e nem a algo mais ou menos verdadeiro do que os xapono atuais, mas, pelo contrário, ressaltando justamente seu caráter mais transitório, próprio das circunstâncias sociopolíticas daquele momento, quando a mobilidade era mais intensa e tal estratégia se fazia assim devida. Assim como no exemplo de Watoriki, uma descrição mais detida das configurações dos atuais xapono Pukimapiwëteri principalmente do Pukima Cachoeira e do Pukima Beira, onde desenvolvi a maior parte do trabalho de campo - pode ser exemplar para observar essa escala entre durabilidade e efemeridade. Ao mesmo tempo, através da descrição de seus processos construtivos, permite-nos aprender como que se faz um xapono e, com isso, o que faz do xapono um xapono.

O processo de se abrir um novo xapono é decerto variável em função dos arranjos políticos e dos potenciais conflitos que movem a mudança. Entre os Yanomami do Alto Rio Marauiá, conforme me explicou certa vez Adriano Pukimapiwëteri, përiomì ("liderança") do Pukima Cachoeira, esse processo tem início com a identificação do novo local possível de moradia. Estes costumam derivar de observações dos patapata pë (os "anciões", os "velhos") e do próprio përiomí, através de caminhos de caça pela floresta ou de regiões dos quais esses têm as suas roças. A identificação de um local possível, contudo, depende de alguns fatores determinantes. Primeiramente, a área deve ser elevada o bastante para evitar inundações, estar próxima de igarapés de água limpa e potável e ter ao seu redor boas condições do solo para plantio. Ao mesmo tempo destaca-se também a disponibilidade de uma área plana o suficiente para comportar todo o diâmetro do xapono, de acordo com o tamanho de sua população. No entanto, para além do fator pragmático, o plano do terreno é também um critério estético da maior importância já que permite a execução plena das sessões diárias de pajelança hekuramou e das danças praiä, realizadas especialmente durante a festa funerária reahu, e também a devida visibilidade entre todas casas do círculo do xapono, condição para a manutenção da sociabilidade adequada do grupo (ponto que retomaremos no capítulo "Viver junto"). Sobre esse ponto, certa vez conversava em português com Francisco Pukimapiwëteri, irmão de Adriano, e ele me listava os xapono "mais legais e bonitos" que ele havia visitado e assim 


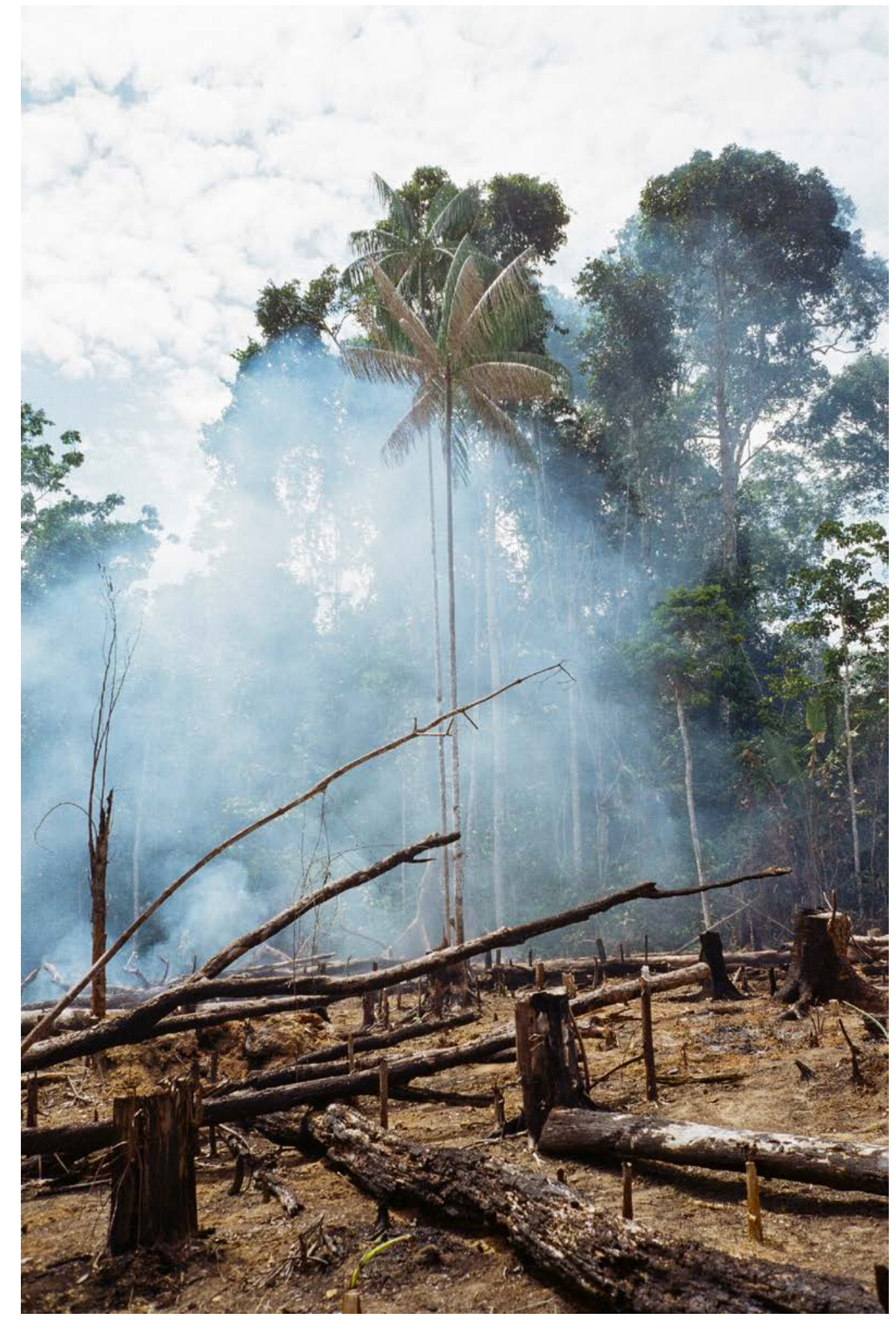

Fig. 32. Roça (hikari të ka) sendo queimada próxima ao Pukima Cachoeira (2019). 
explicitava, justamente, seus respectivos critérios mais fundamentais: "era bem planinho e bem limpinho" (retomaremos mais adiante a questão da limpeza do meio do xapono e as suas respectivas implicações estéticas e também xamânicas).

Segundo Adriano, após a identificação do novo local, o përiomì reúne a população do xapono para dialogarem sobre a ideia e é apenas com o aceite de todos que a mudança é efetivada e o plano é seguido. No entanto, antes do mutirão para a abertura da clareira que irá abrigar o círculo de casas, de acordo com o que me explicou em outra ocasião Francisco, o ato de se abrir um novo xapono implica em uma transformação dupla da floresta (urihi). Em primeiro lugar, as famílias que compõem o grupo local daquele xapono (existente ou a partir da fissão de algum outro) abrem clareiras menores nos arredores onde serão feitas as primeiras roças (hikari $t \ddot{~} \mathrm{ka}$ ). Estas podem ser feitas ao redor do perímetro onde se planeja abrir a clareira para as casas ou, a depender da qualidade do solo, em áreas próximas e facilmente acessíveis por curtas caminhadas, conectandoas futuramente ao novo xapono. Este procedimento pode anteceder em vários anos a mudança planejada ou, em outras situações, pode mesmo indicar, a partir das roças já existentes, um novo local possível de morada. A abertura das roças, portanto, é condição determinante para a mudança e, como explicou-me Adriano, deve-se antes avaliar o desempenho destas, simplesmente, "para não passar fome depois".

Desse modo, ao ocupar uma nova área, o nome dado ao local primeiramente indica o roçado, com o topônimo seguido do classificador të ka, por exemplo, Pukima të ka. O classificador të ka, de modo geral, indica uma cavidade, um buraco ou um vazio e, no caso do roçado (hikari), anaforicamente, refere-se à clareira, isto é, ao espaço aberto e livre de árvores, como um buraco escavado na densa cobertura vegetal da floresta, um terreno limpo e roçado onde se encontram as plantas cultivadas (Lizot, 2004, p. 88/436). Com a construção do xapono, por extensão, o topônimo passa então a indicar a casa-aldeia, e não mais a clareira e o roçado em particular - isso, no caso do xapono ser feito no mesmo perímetro que as roças de mesmo nome, ao contrário, pode haver mais topônimos indicando de forma distinta o espaço do xapono e das roças. Assim, conforme me explicava Francisco, depois que as casas são construídas, o local passa a ser reconhecido, fundamentalmente, enquanto um xapono, e não mais enquanto roça ou clareira, hikari të ka ou Pukima të ka (cf. Cocco, 1972, p. 141). 
A mudança do grupo local para a nova morada, então, costuma acontecer no tempo de colheita das roças de banana ou mandioca. Com isso, permite-se que as famílias dediquem o trabalho diário quase que exclusivamente na morosa limpeza da clareira e na construção das primeiras casas. Em 2016 acompanhei a mudança rio acima dos Yanomami do xapono Pukima Beira e, nesse contexto, pude trabalhar junto e aprender com esse processo de fundação de uma nova casa-aldeia. No momento da mudança do grupo como um todo, já havia passado alguns meses em que os homens (na maioria homens, mas não só) da aldeia frequentavam quase que diariamente a nova clareira. Nessas idas, distante cerca de meia hora de barco pelo rio, os "trabalhadores", como diziam em português, se embrenhavam no mato, para coletar materiais na floresta, ou ficavam trabalhando no xapono, na limpeza da clareira ou na construção das casas. Com isso, quando todo o grupo se mudou, em um só dia, fazendo diversas viagens de barco, a maioria das casas estavam semi-prontas, ou seja, com a estrutura principal construída, mas ainda com os tetos por cobrir e os lados por fechar. Durante esse primeiro momento, então, as casas eram cobertas com lonas, como em um acampamento provisório.

A abertura da clareira ocorre de maneira vagarosa e através de simples meios: enxada, facão, terçado, machado e muitas mãos. Esse processo é inicialmente dividido em função de uma espécie de setorização prévia dos locais onde serão construídas as casas de cada família, de modo que cada grupo familiar é responsável pela limpeza de sua área, a sua respectiva fatia do círculo da clareira. Quando os troncos a serem cortados são grandes demais, organiza-se um grupo para trabalhar juntos e cavase ao redor de suas bases de modo a expor suas raízes. Com isso, tira-se a sustentação da terra que os cerca a fim de desestabilizá-los e, cortando suas raízes, é então possível tombá-los, queimá-los e torá-los. Essa tarefa é pacientemente manejada, inclusive, por idosos e idosas que, em vez de ir ao mato buscar algum tipo de material, acabam executando os trabalhos na própria aldeia em obras. Além disso, estes se engajam também na limpeza fina e na complicada terraplenagem do meio do xapono, feita após o grosso da abertura da clareira. Esse processo é cuidadosamente feito de cócoras, com auxilio de um facão, de modo que cada grão de impureza vegetal ou mineral é filtrado e reunido em uma porção de montículos distribuídos pelo pátio, partindo da frente das casas para depois serem reunidos em um cesto de palha e jogados em algum lugar nos fundos das casas. Assim, 
os "trabalhadores" limpas e nivelam porções consideráveis da clareira doméstica, literalmente de punhadinho em punhadinho, arremessando a terra filtrada e excedente para as áreas mais baixas do terreno. Pouco a pouco, de torrão a torrão, a clareira começa a tomar o aspecto de um terreiro plano, limpo e reluzente - características fundamentais que, como veremos no capítulo "Casa-montanha", têm implicações estéticas e cosmológicas com a limpeza do corpo dos pajés pelos seres-imagem hekura durante o processo de iniciação xamânica taamayõu.

Como sugere Jacques Lizot, a setorização do círculo da clareira para a organização do trabalho e para a implantação das casas - seja em uma aldeia de teto único, e posteriormente unido, ou em uma com as casas separadas, como é o caso do Pukima Beira - corresponde a uma espécie de "geografia do parentesco" (Lizot, 1984, p. 113). Nesta, irmãos e primos paralelos, quando já casados e normalmente com seus próprios filhos e eventualmente também alguns de seus filhos solteiros -, habitam em casas contíguas, formando uma unidade da facção familiar e ocupando em bloco uma seção do círculo doméstico. Os xapono são assim compostos por blocos residenciais de seções familiares e nos centros de cada um desses estão as casas dos patapata pë, os anciões e anciãs mais velhos da família, "os postes da casa". Essa geografia entre consanguíneos e afins representa uma certa "expressão espacial da estrutura social" (Lizot, 1984, p. 113), contudo, esta não é absoluta e tampouco estática, mas, pelo contrário, está sujeita aos diferentes arranjos familiares gerados e dissolvidos com o tempo, de modo que variações no arranjo das casas entre as famílias e facções são não só possíveis como relativamente comuns. E diferente dos arranjos internos das malocas (longhouses) do noroeste amazônico (HughJones, C., 1979, p. 48), por exemplo, no arranjo circular do xapono não há uma hierarquia estabelecida ou qualquer predeterminação a respeito da posição (ou escala, forma etc.) das casas dos përiomi - como vimos, as "lideranças" do xapono, com um "chefe" principal e outros (um ou mais de um) correspondentes a cada facção familiar.

É essa geografia dinâmica do parentesco, também, que orienta a responsabilidade pela construção das casas de cada família, levadas à cabo, sobretudo, pelos genros atuais ou pretendentes, mas também pelos filhos ou netos da casa. No caso de um casamento uxorilocal, no qual o homem muda para o xapono e para a casa da família da noiva, por exemplo, é comum que após alguns anos o casal saia dessa casa e retorne 


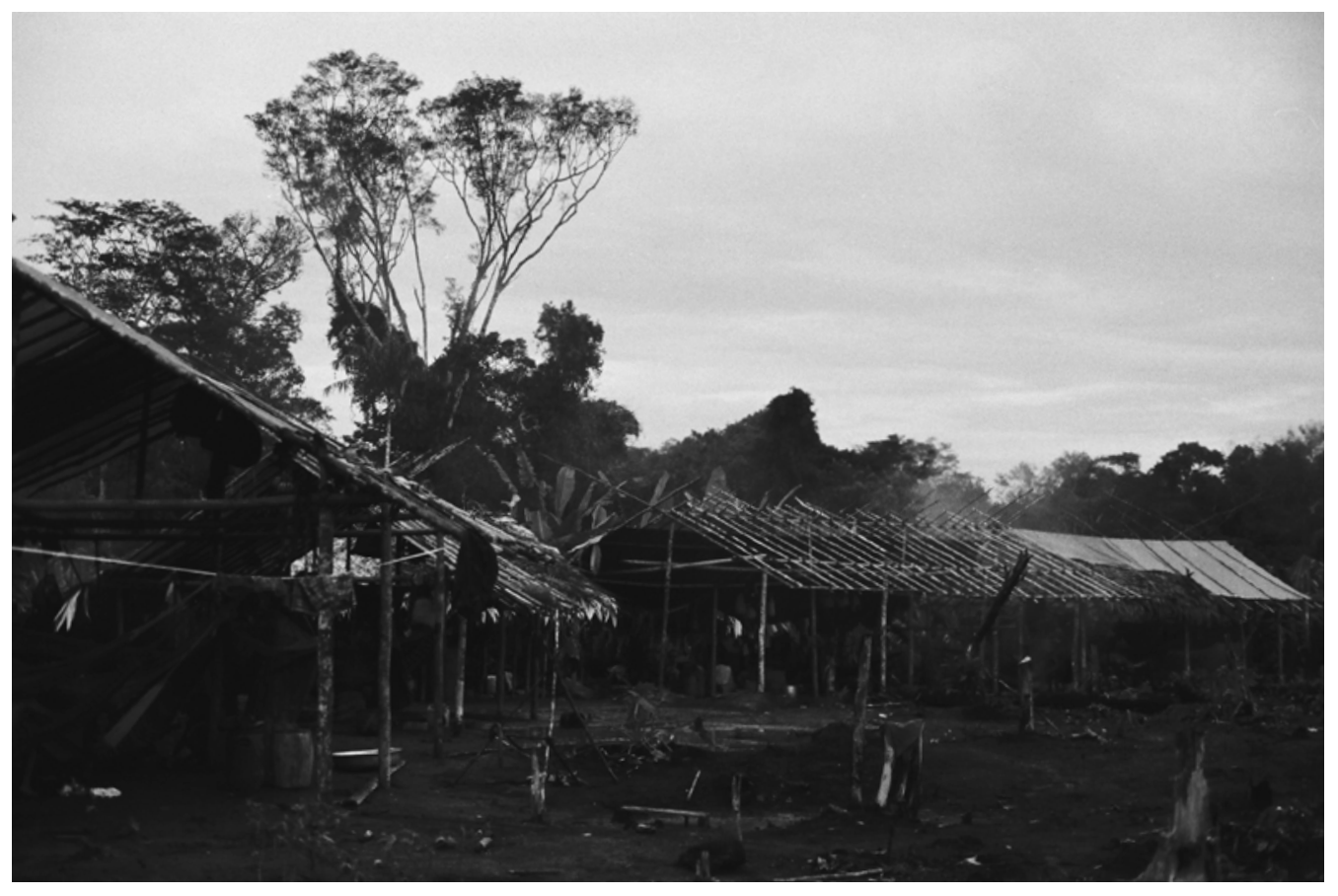

Fig. 33. Amanhecer no novo xapono Pukima Beira, em 2016, poucos dias após à mudança para a nova clareira. As casas seguem em obras, com os telhados parcialmente cobertos (em apenas um lado, como nas casas "tipo tapiri") ou improvisados com lona (como se vê à direita e ao fundo), com as famílias ocupando-as provisoriamente enquanto trabalham na construção destas e na limpeza do meio do xapono (fotografia de Daniel Jabra). 
para o xapono onde habita o grupo familiar do marido, se reintegrando na seção familiar virilocal e construindo sua própria casa. Nesse caso, o casal provavelmente terá seus filhos novos demais para o trabalho na construção ou para outros casamentos, de modo que o marido que deverá se responsabilizar pela construção da nova casa da família, eventualmente contando com a ajuda de seus irmãos. No entanto, se o grupo familiar de sua esposa construir uma nova casa ou mudar de xapono, o casal pode voltar para a casa da família da noiva para que o genro possa trabalhar para o sogro na construção da sua nova morada, tarefa essa que pode ser coordenada junto dos demais genros ou cunhados, mas que demanda grande dedicação sob auspício do sogro e chefe de família. O mesmo trabalho duplo de construção das casas ocorre também quando o casamento se dá nos contornos do próprio xapono, de modo que o jovem marido deve construir sua casa e, quando necessário, trabalhar detidamente também na construção da casa de seu sogro, assim como na abertura e no cuidado cotidiano de suas respectivas roças, até que a família se organize e, de forma autônoma, tenha seus próprios genros e seus próprios roçados.

A construção das casas - baseado na minha experiência prática com interlocutores-construtores do Pukima Beira em 2016, mas também em distintas experiências pontuais no Pukima Beira e no Pukima Cachoeira entre 2019 e 2020 - , então, decorre da seguinte maneira. Após cortar e carregar os primeiros troncos e toras para a aldeia, aqueles que servirão de esteios para a nova morada, deve-se posicioná-los em seus devidos lugares, cavar suas valas com cerca de um metro terra adentro e socálos contra o solo. Uma vez nivelado e concluído o processo de colocação dos esteios, tampam-se as valas e o acabamento é feito com o pé ou com um pilão improvisado, prensando, apertando e ajustando a terra e o piso ao redor. O número de esteios, assim como a modulação dos vãos de sua implantação, a espécie ideal de madeira (mais ou menos durável) e o comprimento de suas peças variam em função do tipo, do tamanho e da intenção da durabilidade da casa e, como veremos mais adiante, um exemplo concreto de uma casa no Pukima Cachoeira poderá elucidar essa descrição. Estes elementos, que correspondem aos pilares da casa, segundo meus interlocutores, são nomeados genericamente de totahima. Como vimos no capítulo "Tapiri”, este termo pode indicar metaforicamente as "mulheres", sendo aquelas que penduram sua redes nesses postes que podem também referir-se especificamente aos postes do fundo da casa. 


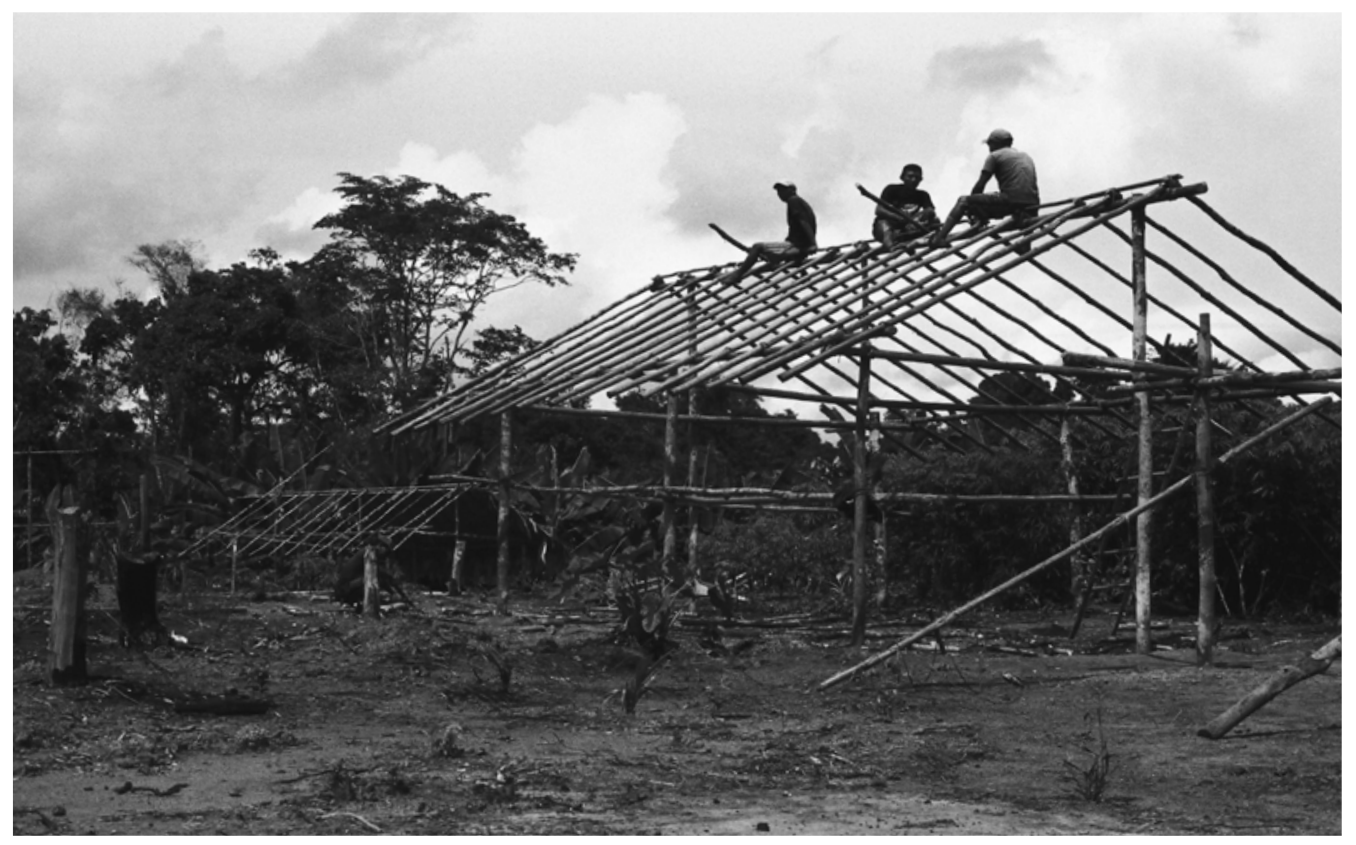

Fig. 34. Casa (yahi) em obras no novo xapono Pukima Beira, em 2016, com o meio do xapono (xapono heha) estava sendo gradualmente limpo. Diferente da casa ao lado, esta vinha sendo construída de maneira mais durável e mais permanente, $\mathrm{e}$ por isso maior (fotografia de Daniel Jabra). 
Outros termos, no entanto, podem ser utilizados para distinguir os pilares dos fundos da casa (xikã), xikã nahi, e os da frente da casa, face ao meio do xapono (xapono heha), heha nahi. Como se nota, nahi, aqui, é utilizado não enquanto termo genérico para casa, como é também possível, mas como classificador nominal que designa os elementos de madeira utilizados na construção da casa, em função de sua organização espacial e da oposição entre os fundos e a frente do espaço doméstico.

Plantados os esteios, a estrutura (yahi) é travada com as vigas longitudinais (paralelas aos fundos e à frente da casa), pariparima, e as transversais, rereorewë. Sobre estas últimas, apoiam-se os tirantes da tesoura do telhado, payihiorewë, que irão suportar a viga longitudinal da cumeeira, chamada também de pariparima. Assim, apoia-se sobre a viga da cumeeira e as longitudinais as varas utilizadas como caibros do telhado de duas águas, hõrõhõrõma, que ultrapassam cerca de um metro o alinhamento das vigas da frente e dos fundos da casa e, com isso, fazem um generoso beiral, protegendo a estrutura e o interior da casa das chuvas, aumentando a durabilidade da madeira.

Há ainda uma outra viga (ou travessa) que pode ser colocada nas casas mas que não tem uma função estrutural, e sim ritual. Chamada também de paríparima esta é colocada de forma longitudinal um pouco abaixo da viga de cumeeira, amarrada com cipó nos tirantes da tesoura do telhado e são pintadas com motivos gráficos, como as linhas sinuosas com pontos ou pequenos círculos intercalados entre suas curvas - como sequenciais casas-aldeias na beira de um rio caudaloso - e pintadas com urucum, alternando linhas e pontos de preto ou vermelho, ou com uma base vermelha em toda a viga e as linhas e pontos em preto. A função das vigas, no âmbito do reahu, é pendurar os muitos cachos de banana que, na madrugada anterior ao desfecho da festa, serão utilizados para fazer o mingau de banana. Encerrando o reahu, o mingau será consumido junto com as cinzas dos ossos do corpo falecido e festejado. Esses cachos, distribuídos em linha em toda a extensão da frente da casa, constituem assim uma espécie de frontão vegetal na casa do dono da festa, isto é, aquele parente, normalmente consanguíneo, que organiza os preparativos do reahu, incluindo, principalmente, o arranjo com os convidados, a caçada coletiva e a provisão de bananas e pupunha (ou mandioca, para fazer beiju, a depender da época). Este frontão vegetal, portanto, não só indica no xapono quem está providenciando o festejo como transforma- 


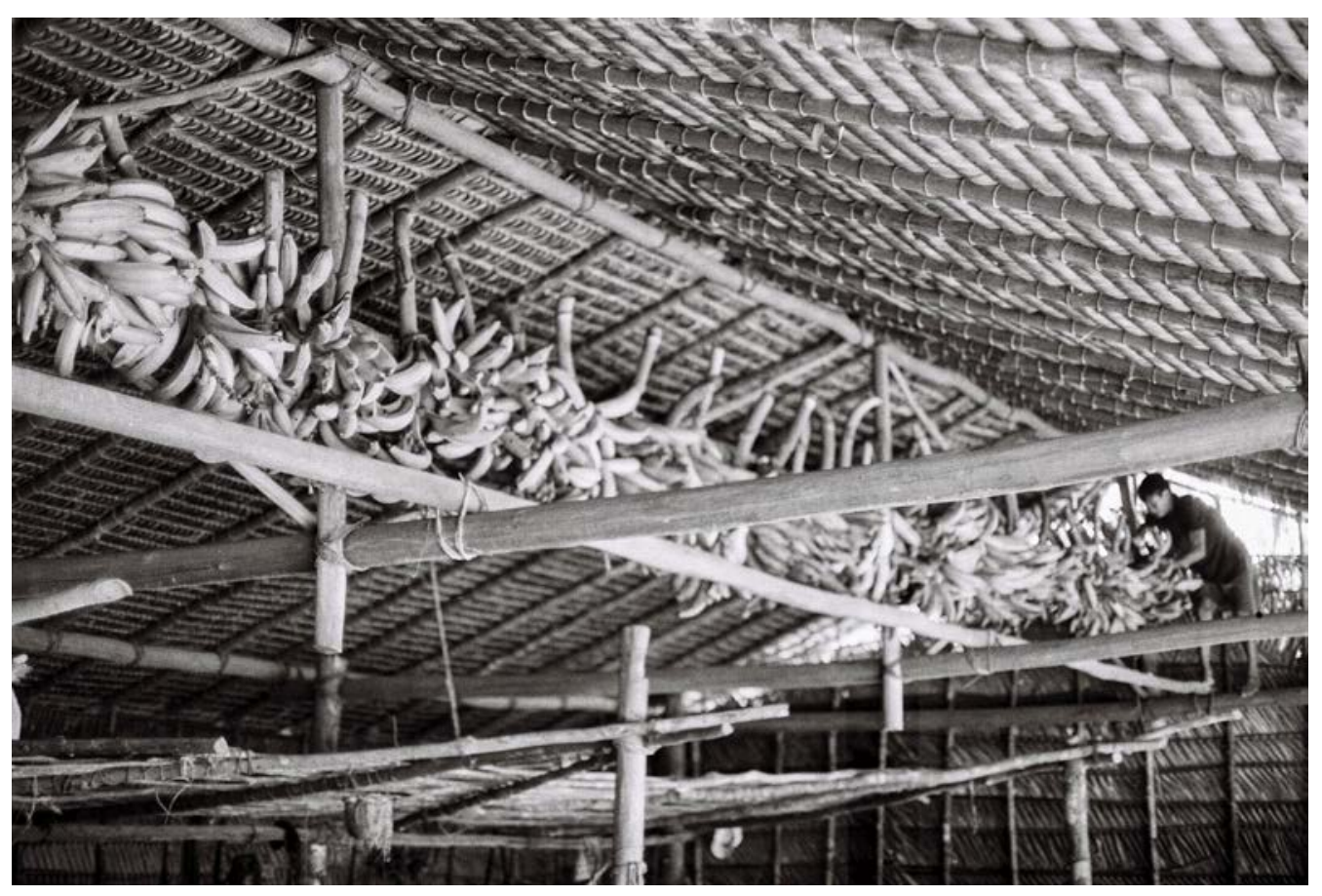

Fig. 35. Viga longitudinal (pariparimi), amarrada entre os tirantes da tesoura do telhado e, em toda sua extensão, preenchida por cachos de bananas para a festa reahu que se aproximava. Abaixo dela, como se nota, duas estruturas triangulares do ihira, na casa de Leonel, do Pukima Beira (2019). 
se também numa espécie de cronômetro que determina o início da festa, com a dança de apresentação dos convidados praiai, de acordo com o tempo de maduração das bananas. As bananas são fixadas nessa viga pelos talos amarrados com cipó, uma ao lado da outra e alinhados pela parte de cima, e quanto mais bananas houver e quanto mais carregada estiver a viga adornada com esse fruto mais prestígio adquire o dono da festa. Assim, evidenciam não só a capacidade produtiva de sua roça e de seus familiares co-residentes como, também, a extensão e a potência de sua rede de relações com outros xapono aliados que podem também fornecer mais bananas (e também mandioca e pupunha) para a festa da qual foram convidados. Após a festa e depois que todas bananas foram consumidas com o mingau, as vigas são mantidas, por vezes, com a mesma função de pendurar cachos de bananas para madurar e serem consumidos pela família e, em outros casos, com funções diversas, transformando-se, por exemplo, em estantes ou suporte para penduricalhos variados. Aos poucos a pintura de urucum perde a coloração, embora em um futuro próximo a viga possa ser retomada, re-adornada e recarregada para uma nova festa.

De volta aos componentes estruturais da casa, os telhados possuem inclinações variáveis, mas sempre entre trinta e quarenta e cinco graus, sendo essa a inclinação média adequada para o tipo de cobertura com palha. Nas casas com telhado de duas águas não-simétricos, como veremos no exemplo a seguir, os caibros hõrõhõrõma dos fundos da casa mantêm o mesmo ângulo, mas são mais compridos e, caso prolongados, chegam próximos do chão. Todos esses elementos são amarrados com cipó titica (masimasima, Heteropsisflexuosa). No caso da estrutura principal de pilares e vigas os nós de cipó são em forma de "X", okaoyakiraorewë, enquanto os caibros podem ser amarrados de forma mais simples em forma de "/", okaorewë, tal como vimos na descrição dos yãno, os tapiris na floresta.

Sobre os caibros, as ripas onde serão fixadas as palhas de cobertura podem ser feitas de duas formas. A primeira, tida como a solução tradicional (assim como vimos acima no caso de Watoriki) consiste em fiadas de cipós titica, espaçadas umas das outras cerca de vinte centímetros. Os cipós são esticados entre os caibros, envolvendo-os com uma volta e, quando necessário, emendados a outros para que completem a extensão total da cobertura. No caso do Rio Marauiá, as folhas mais abundantes na floresta e mais utilizadas para a cobertura das casas são as das palmeiras ubim (komixë, Geonoma baculifera), embora por vezes, como alternativa 
à escassez de ubim, utilize-se também folhas da palmeira caraná, curuá (yawatoa), sororoca (këtipa), buçu (toutou) e açaí (wãima henakì). Nessa solução com os caibros-cipós, as folhas de ubim são colocadas muito próximas umas das outras, com o talo de uma encostando no talo da outra, resultando em uma cobertura mais resistente e mais bem acabada que, consequentemente, demanda um maior número de fardos de palha, além de mais trabalho para sua coleta e para seu transporte da floresta para a casa-aldeia. Para fixação destas nos fios de cipó, então, o talo da folha é dobrado, de modo que a parte do talo que foi dobrado dá a volta em um cipó e a ponta é apoiada sobre a linha de cipós abaixo. Assim, as linhas de cipó e folhas são sequencialmente travadas pelas que vem imediatamente acima, uma pesando sobre a outra e segurando o conjunto. A outra técnica de colocação da palha, portanto, parece ter sido apreendida mais recentemente e, no geral, é vista como a solução menos durável, já que permite um maior espaçamento entre as folhas e, com isso, mais chances de com o tempo o telhado se deteriorar com o tempo. Para esta alternativa utiliza-se ripas de paxiúba (Socratea exorrhiza) apoiadas sobre os caibros e as folhas de ubim são colocadas nas ripas com uma amarração na qual o talo da folha envolve a ripa e, com uma dobra, amarra-se nele mesmo. Essa técnica é chamada de yãtõrimano, sendo que yãtõri-é a raiz verbal de yãtõriat, verbo intransitivo que significa "enrolar-se, envolver-se ao redor de algo", nesse caso ao redor das ripas, e que indica também um estado, justamente, yãtõrimano, aquilo que foi "amarrado dessa maneira" (Lizot, 2004, p. 503).

Em ambas as técnicas, o processo de cobrir as casas é bastante trabalhoso e, assim como ocorreu na mudança do Pukima Beira em 2016, faz com que as famílias se organizem em pequenos mutirões para coleta, transporte e colocação das palhas. Dessa forma, depois que a palha é cortada e carregada, é fundamental que o telhado seja trançado o quanto antes para que ela seque e se assente na própria cobertura, caso contrário, pode tornar-se muito quebradiça e mesmo totalmente inutilizável. O processo de coleta e transporte desses fardos, para cobrir uma pequena casa, por exemplo, pode ser repetido uma dúzia de vezes e é feito da seguinte forma. As folhas são localizadas, cortadas e amontoadas numa pequena clareira na mata, distribuídas em pilhas sobre um tipo de jamanxim (cesto ou mochila feita de palha ou cipó). Para esse processo, faz-se uma estrutura engenhosa de paus fincados no solo para que as 

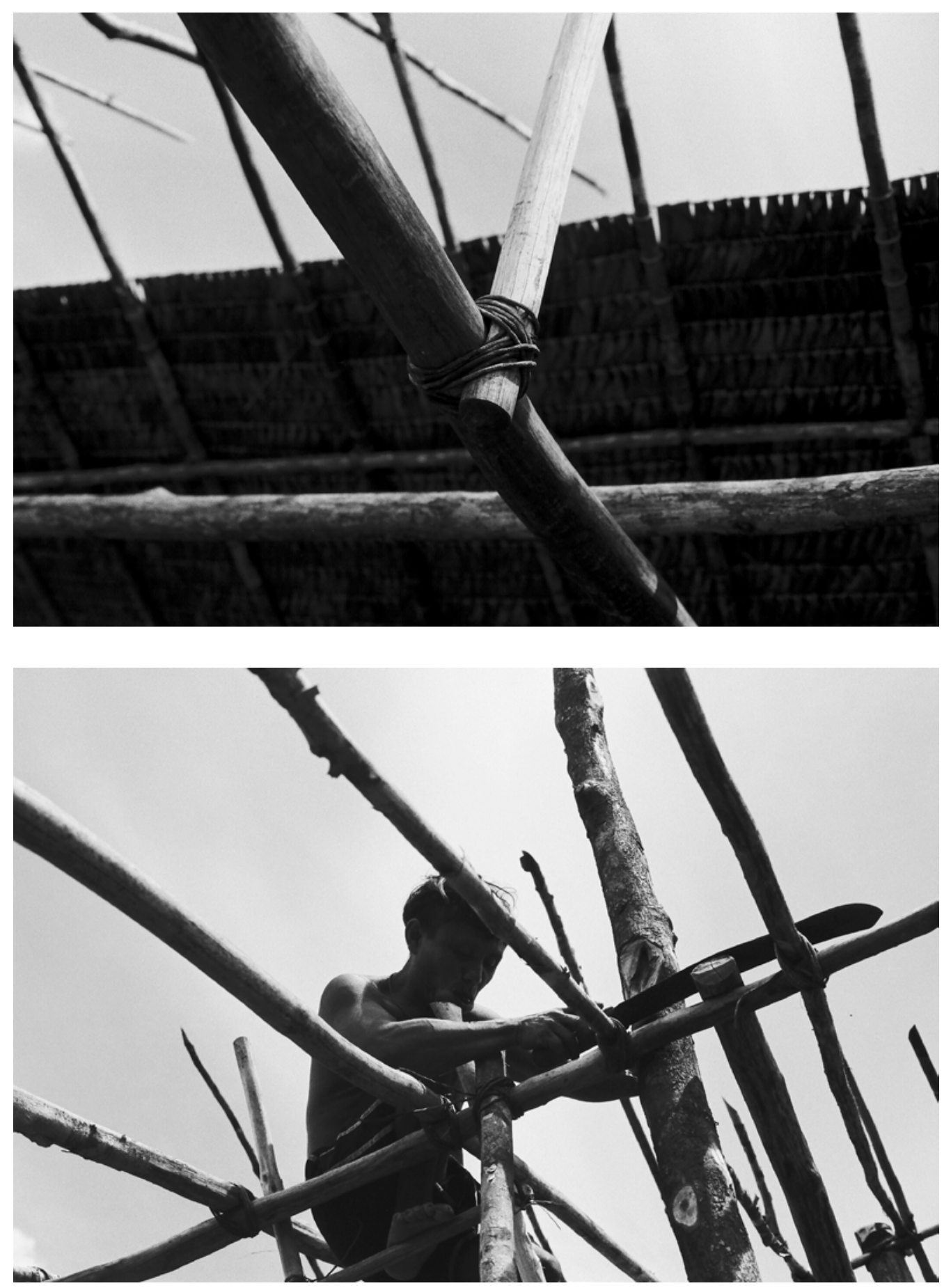

Fig. 36/37. Acima, nó de cipó em " $\mathrm{X}$ " (okaoyakiraorewë) entre a viga transversal (rereorewë) e o tirante da tesoura da cobertura (payihiorewë), com a solução das folhas de ubim (komixë) colocadas em linhas de cipós. Abaixo, colocação e amarração dos caibros (hõrõhõrõma) sobre viga de cumeeira (pariparima). Ambas, no novo xapono Pukima Beira (Daniel Jabra, 2016). 


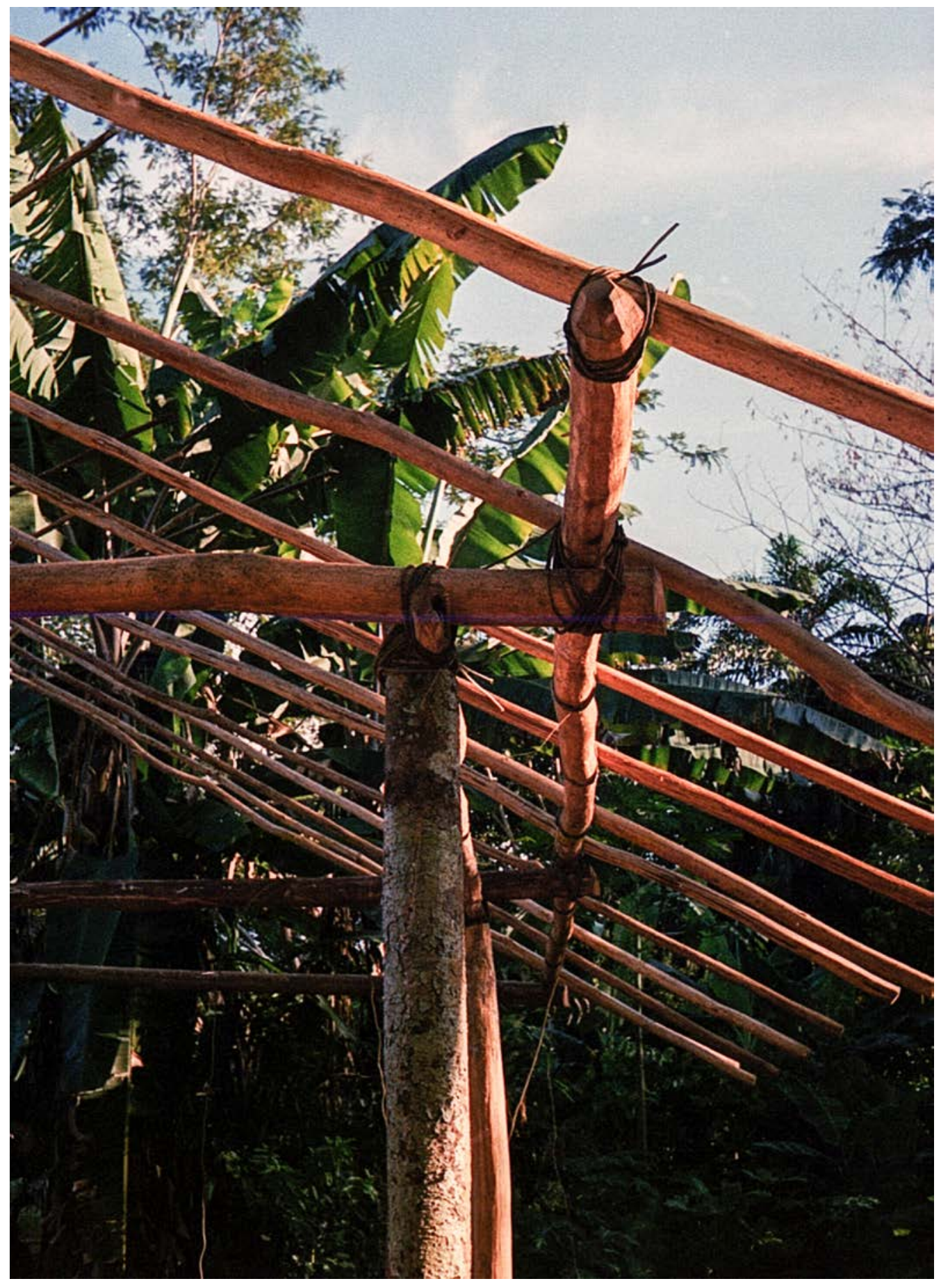

Fig. 38. Detalhe construtivo do encontro da viga transversal (pariparima) e longitudinal (rereorewë) com os caibros (hõrõhõrõma) e o pilar (totahima) em uma pequena construção de uma "casa do forno" atrás da casa de Claudio no Pukima Cachoeira (2020). 

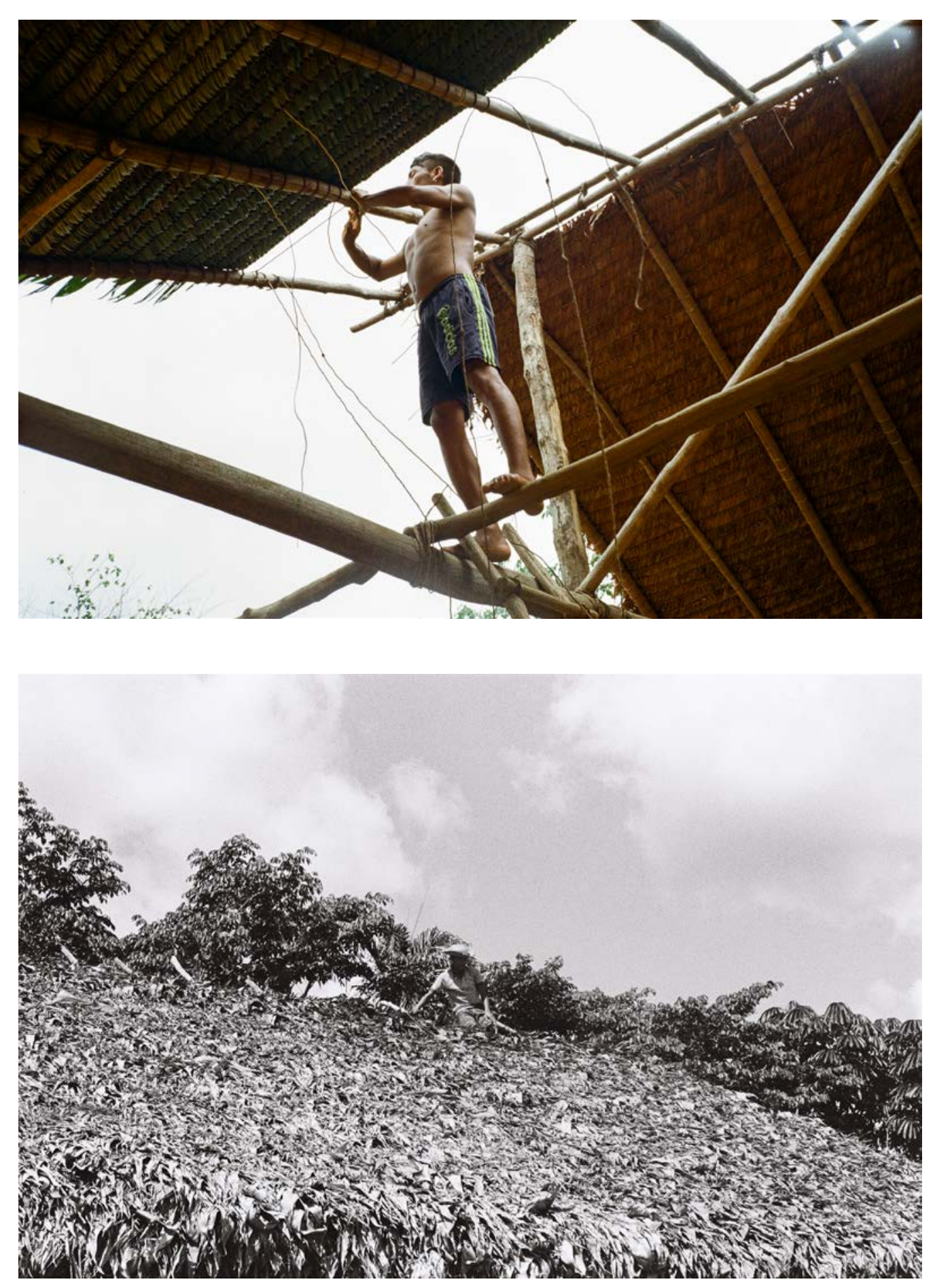

Fig. 39/40. Acima, linhas de cipó sendo colocadas na cobertura de uma casa em obras no xapono Pukima Cachoeira (2019). Abaixo, Crispinho, trabalhando na cumeeira da casa de Cândido, seu avô, e completando a colocação de palhas na cobertura da grande casa, no xapono Pukima Cachoeira (fotografia de Daniel Jabra, 2019). 


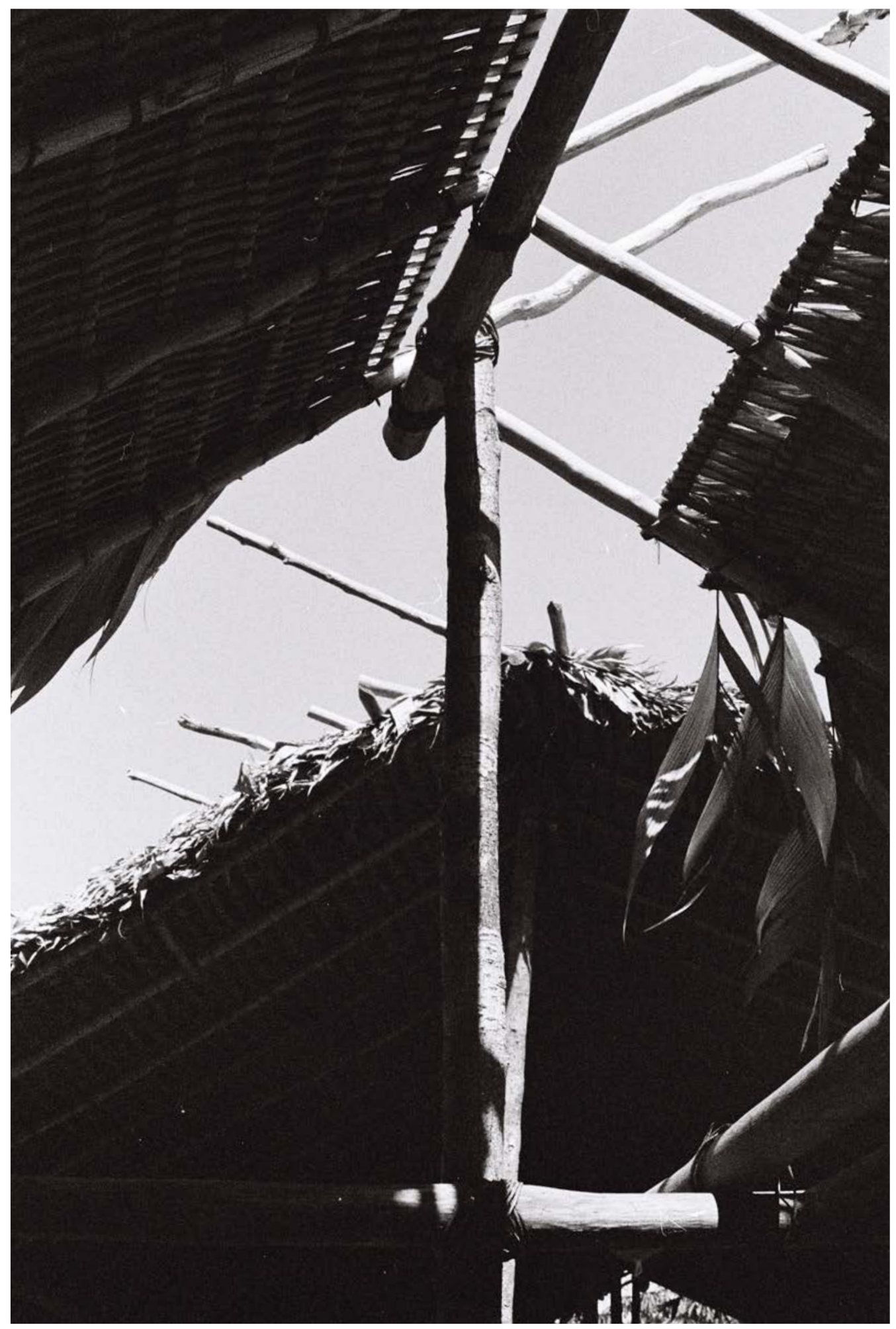

Fig. 41. Detalhe da cobertura de uma casa em obras com folhas de ubim e ripas de paxiúba no xapono Pukima Cachoeira (Fotografia de Daniel Jabra, 2019). 
folhas não deslizem para os lados ao serem empilhadas sobre o jamanxim que está no chão. Esse jamanxim tem um formato oval, feito com um cipó grosso e flexível com cerca de três centímetros de diâmetro, e é trançado com cipós titica, como uma mandala, do tamanho das costas de um adulto. Uma vez pesado o bastante, as palhas são amarradas no jamanxim com o mesmo cipó titica e uma casca de árvore, como uma faixa, é adicionada para que se carregue a pesada mochila apoiando-a na testa ou no peito. Ao fim, é hora de caminhar de volta à obra.

Em alguns casos é notável também que, sobre a cobertura de palha, sejam colocados uma série de paus, mais ou menos do comprimento da água do telhado e de tipos e espécies quaisquer, apenas apoiados sobre as folhas, para que evite que fortes ventanias prejudiquem a fixação das palhas e, com isso, aumente a durabilidade do telhado. Esse tipo de problema com fortes ventos costuma ser agravado quando as casas possuem telhados de apenas uma água e, como observei acima, é também uma das razões para a atualização da forma da cobertura com teto de duas águas. Além disso, conforme relata Cocco, nos antigos xapono com casas de tetos de uma água, eram colocados na ponta superior dos telhados uma série de cipós que permitiam que os moradores da casa, ameaçados pelos fortes ventos, os puxassem para baixo, aterrando a estrutura e segurando o teto, literalmente, com as próprias mãos. Outra solução, relatada pelo mesmo autor, para o mesmo tipo de casa e para o mesmo problema, são folhas de palmeiras que, colocadas na parte alta dos telhados, em fardos, além de protegerem da incidência solar ou de chuvas de vento, funcionam também "decorativamente e têm a finalidade de pesar sobre a extremidade do teto para que o vento não o levante" (Cocco, 1972, p. 144).

Diferente dessas casas de apenas uma água, o que se faz nos xapono do Marauiá atualmente é algo como a "solução eclética", tal como dito por Cocco (1972, p. 149). No entanto, essa solução transforma o "yahi clássico" ("tipo tapiri") não nas "casas tipo 'racional" - que nas palavras de Cocco correspondem a "uma morada ao estilo crioulo e típica do território do Amazonas [Venezuela]" (1972, p. 148) -, mas em uma forma atualizada dele mesmo. Especificamente o que Cocco se refere como a "solução eclética" são as casas com telhado de duas águas, mas com a frente da casa aberta ao meio xapono e com os fundos, tal como no "yahi clássico", fechado (por distintas razões que veremos a seguir). Nessa solução, nota o autor, as casas são melhor protegidas das intempéries - da chuva, do 
sol e da umidade - e também são mais bem aquecidas, pelas fogueiras domésticas no centro dos triângulos de redes, protegendo e esquentando os habitantes do frio da madrugada (Cocco, 1972, p. 149). No geral, a maioria das casas (yahi) dos xapono do Rio Marauiá seguem esse modelo, muito embora algumas casas apresentem também fechamentos diversos na parte da frente.

No entanto, há uma outra solução em prática no Alto Marauiá que gera uma configuração "eclética" distinta da anteriormente descrita. Como observado acima, trata-se das casas em que os telhados de duas águas não são simétricos, pois o lado dos fundos, tal como no "yahi clássico" ("tipo tapiri"), onde se situam as redes e as fogueiras, é prolongado até perto do chão e fechado com palha ou ripas de madeira, enquanto o lado interno é mais curto, abrindo-se para o meio do xapono (xapono heha) mas ainda protegendo a frente da casa das intempéries. Essa solução, por conta da aba prolongada do telhado, demanda maior coleta de materiais e, com isso, gera mais trabalho. Além disso, como também resulta numa construção mais sólida e mais durável, essa solução implica em uma maior estabilidade no novo local de moradia. Por isso, essa solução costuma ser construída apenas na segunda casa de uma família, ou seja, aquela subsequente à primeira casa construída após a mudança para uma nova clareira, já que nesse movimento inicial de mudança o trabalho se expande também à limpeza do meio do xapono e à abertura de novas roças. Esse tipo de dinâmica, então, confere ao xapono um movimento contínuo de construção das casas. Esse movimento, ainda, reflete o fato de que como as casas são "individuais" e não unidas umas às outras, permite-se assim que cada grupo familiar faça esse processo de construção e reconstrução em tempos diferentes, expandindo a duração da obra do xapono de acordo com às expectativas de permanência naquele localidade. Logo, os xapono estão sempre em obras.

Um exemplo desse processo pode ser notado através da mudança do grupo do xapono Pukima Beira em 2016 que pudemos acompanhar e auxiliar. Naquele momento, as primeiras moradas foram construídas de forma mais provisória, com casas menores feitas de materiais mais frágeis e de forma mais ágil, simplificando o processo construtivo. Inclusive, aventava-se na época a possibilidade de logo se mudarem, já que haviam, de certa forma, desaprovado a nova clareira, dado os limites topográficos do terreno para possíveis expansões do xapono no futuro. 
Diziam, inclusive, que já estavam abrindo outra clareira, ao passo em que a atual nem havia sido completamente limpa. Anos depois, entre em 2019 e 2020, o plano mudou e o xapono, estabilizado naquele local, apresentava outra configuração. As pequenas casas improvisadas com telhado de uma ou duas águas foram refeitas e transformaram-se em casas mais amplas (prontas ou ainda em construção), seguindo a solução assimétrica e "eclética". Outro exemplo do mesmo processo pode ser descrito com a construção da segunda casa de Moisés, segundo përiomi do Pukima Cachoeira, levado a cabo sobretudo por dois de seus genros, os quais pude auxiliar na manufatura do fechamento da casa com tramas de palha em 2019. Nesse caso, a primeira casa da família do përiomi havia sido construída em 2014, quando este grupo se mudou para a atual localidade. A casa foi construída com teto de duas águas, com área reduzida e com materiais mais frágeis, de modo que, em 2019, já apresentava sinais de deterioração, em especial, da cobertura de palha. A segunda casa, então, vinha sendo construída de forma mais vagarosa e também mais cuidadosa, também com o telhado de duas águas, mas em sua solução "eclética", isto é, com a aba dos fundos prolongada quase até o chão. O ritmo e o cuidado próprio dessa segunda construção decorrem simplesmente do fato que a família podia nesse ínterim habitar tranquilamente a pequena casa antiga, além de prosseguir com suas tarefas diárias e regulares de subsistência, enquanto os genros, dedicados quase que inteiramente na construção da nova grande casa, tocavam o trabalho de construção. Essa segunda casa, portanto, vinha sendo construída atrás da primeira, alargando o círculo do xapono, junto de outra casa vizinha também em processo de reconstrução e seguindo a mesma lógica. Com a previsão de conclusão da grande casa, situação que caminhava ao fim durante nossa estadia e trabalho coletivo, era bastante objetivo: a casa seria destruída, a palha eventualmente reaproveitada para alguma cobertura temporária ou queimada e a madeira, simplesmente, viraria lenha.

Com a solução "eclética", como a da casa de Moisés, não só a atualização da estrutura física do "yahi clássico" torna-se visível aperfeiçoando a solução dita tradicional das casas "tipo tapiri" para uma solução contemporânea, mais ampla e sobretudo mais durável -, como também a atualização da organização do interior da casa. Apesar das mudanças formais e construtivas das moradas do Alto Marauiá, a organização espacial do interior das casas (yahi) se mantém, como 
veremos, não de forma fixa mas transformada. Assim, o interior das casas poderia ser divido em três partes que, quando multiplicadas pelo círculo do xapono, se organizam de forma concêntrica. Na fronteira com o "meio do xapono" (xapono heha), o terreiro central de terra batida (que voltaremos a falar mais adiante), está a área chamada de hato nahi heha, traduzível como o "pátio da casa". Essa tradução possível evoca, assim, o sentido mais "púbico" ou "coletivo" (problemas que retomaremos no capítulo seguinte) dessa área que, nas casas atuais de duas águas ("ecléticas" ou não), corresponde à aba interna (no caso das casas sem fechamento frontal ou com o fechamento recuado) do telhado, enquanto, nas antigas casas "tipo tapiri", correspondiam ao beiral em balanço e à parte mais alta do telhado, área menos protegida das intempéries e, portanto, de estadia mais transitória e diurna.

Nesta área de soleira tem-se a visão integral do círculo de casas do xapono e é de onde se emitem as vozes dos diálogos kãwãamou (como veremos no capítulo seguinte "Viver junto"). Nela, também, é onde costumam estar localizados os bancos (rotikëotima) dos pajés (hekura), utilizados nas sessões de pajelança hekuramou. Os bancos são estreitos e baixos e permitem que, durante o hekuramou, estes se sentem como se estivessem de cócoras. Em outras ocasiões, os bancos são de uso comum e circulam pelas diferentes áreas do interior da casa e, inclusive, de uma casa à outra. Feitos de toras esculpidas ou de tábuas serradas de madeira, os bancos têm dimensões variáveis, desde longos bancos que atravessam longitudinalmente as casas, comportando vários pajés durante uma ampla sessão de pajelança, até bancos pequenos e portáteis, pouco maiores que uma palma de mão. Nesse sentido, entende-se também a forma alternativa pela qual esse espaço de soleira pode ser nomeado, tikeorewë, algo traduzível como o "lugar onde se senta".

A área de soleira ou o "pátio da casa" (hato nahi heha), assim, condensa o caráter liminar e de passagem tanto no que diz respeito ao espaço arquitetônico quanto às agências xamânicas caracterizadas pelas capacidades de conexão e mediação com os seres-imagem ancestrais (hekura). Se no espaço arquitetônico do xapono o estado liminar é o que marca a passagem entre o claro e escuro ou o dentro e fora, na ação xamânica a mediação se dá entre o visível e o invisível ou o humano e o extra-humano. Esse estado liminar mediado pela ação xamânica é expresso espacialmente no âmbito da iniciação xamânica taamayõu (ver 

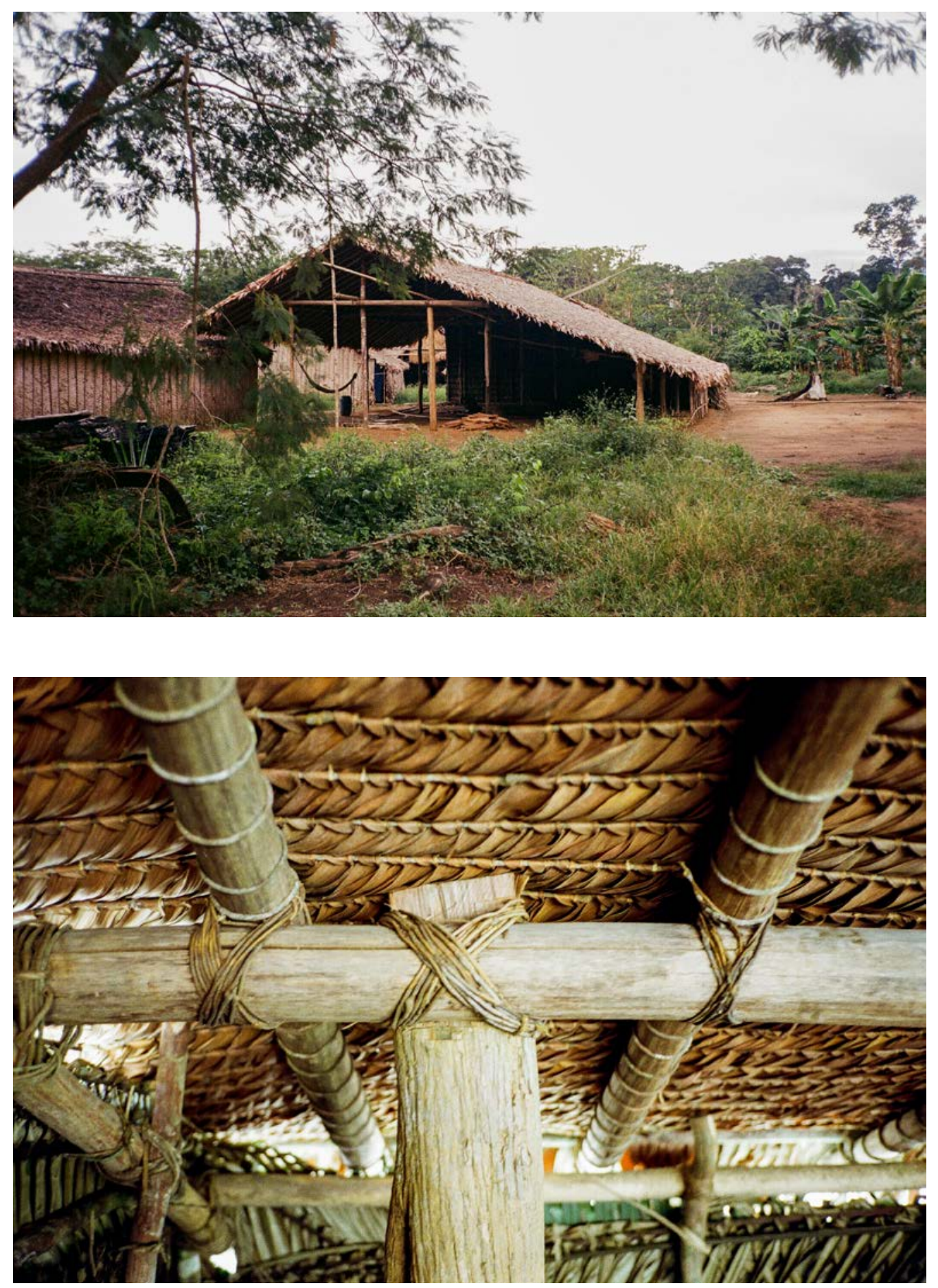


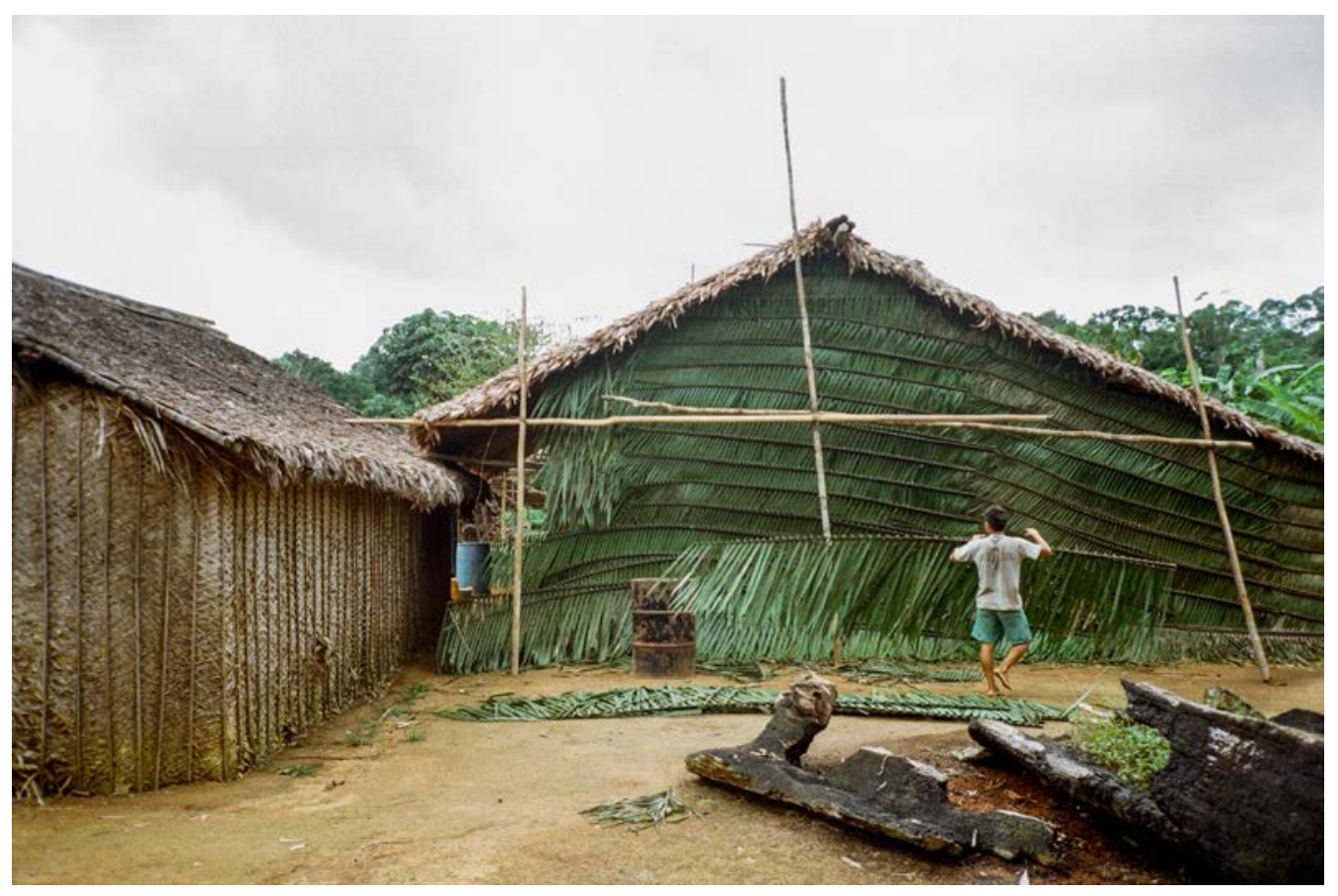

Fig. 42-44. Casa tipo "eclética" de Moisés, o segundo përiomi do xapono Pukima Cachoeira. Acima, na página anterior, vista dos fundos e em obras, conduzida pelos seus genros. E abaixo, detalhe do encontro da viga transversal dos fundos (pariparima) com o pilar (totahima), amarrado com nó de cipó em "X" (okaoyakiraorewë) e caibros (hõrõhõrõma) amarrados sobre a viga com cipós passando sobre e ao redor destes, na área da casa conhecida por "os fundos da casa" ou "o baixo da casa" (hato nahi xĩka). Nessa página, acima, Emerson, um dos genros, trabalhando e me ensinando a fechar as casas com palhas de curuá (yawatoa), sobrepostas e amarradas com cipó. A estrutura de andaimes é para alcançar as partes mais altas da casa e, à frente, praticamente encostando na casa em obras, esta a antiga e pequena casa de Moisés, construída preliminarmente quando estes se mudaram para este novo xapono em 2014. Com a conclusão da obra, aumentando o diâmetro do xapono, a antiga casa irá se tornar lenha, conforme me explicava Emerson (2019). 
"Casa-montanha”). Nessa, para possibilitar e estimular a migração dos primeiros hekura que são chamados e invocados desde os picos rochosas até o corpo do iniciando, situado nos bancos da soleira da casa, os pajés mais experientes tratam de traçar um "caminho dos espíritos", delineado com os próprios pés em movimento ou, eventualmente, sulcando um rastro linear no pátio central do xapono. Como relata de Lizot sobre esse mesmo processo:

[Os xamãs] arrancam o mato e limpam os detritos, as folhas mortas e os gravetos do solo, traçando assim um caminho que chega exatamente entre as pernas afastadas do iniciado. A partir de então, os xamãs utilizarão em seu ofício apenas esse caminho, e sua idas e vinda incessantes farão com que tenha a aparência de um caminho frequentado, atravessando diametralmente a praça central. A atenção dos hekura, desde as cavernas rochosas na floresta que moram, será desviada. Eles serão atraídos, guiados para a abertura que lhes foi consagrada, conduzidos para esse caminho novo pelos xamãs que os encarnam e levados ao peito de Rikõmi [o nome do jovem que está sendo iniciado], sua nova morada (1988, p. 103).

Assim, além do caminho em si, para que a mediação se efetive é necessário atentar-se para a limpeza tanto do espaço do "pátio da casa" (hato nahi heha) quanto do "pátio do xapono" (xapono heha), tal como menciona Lizot e, também, como veremos mais adiante, conectando a liminaridade entre as categorias sensíveis do claro e escuro e do visível e invisível às noções de limpeza e de visibilidade dos hekura.

Além disso, é nesse espaço de soleira - permeado por uma série de valas no solo que drenam as águas da chuva, conduzindo-as aos fundos pelos vãos entre as casas - em que cotidianamente se caminha ao visitar uma casa vizinha ou ao intentar atravessar o xapono de lado a lado. Desse modo, quando houver uma sobreposição do movimento do caminhante com o do pajé sentado fazendo o hekuramou, como marca de respeito, devese passar sempre por trás do ou dos pajés, e nunca pela frente, evitando atrapalhar ou interromper os canais de diálogo com os seres-imagem auxiliares (hekura). Essa caminhada com o intuito de atravessar o xapono, no entanto, sempre deverá ser realizada de forma perimetral e circular, de modo que uma travessia diametral do meio do xapono é potencialmente vista como agressiva e abrupta, expondo o caminhante ensolarado não só aos olhares de todos, diferente do caminho seguido pela sombra do 
beiral dos telhados, como também causando certa consternação naqueles que assim o recebem. Como sugere Perrone-Moisés (2015), falando sobre o pátio central das aldeias timbira do Brasil Central, trata-se assim de espaços que são como uma "marca geométrica da conexão" e, no caso do pátio central (ou também do xapono heha), de um jeito ou de outro, "é preciso atravessá-lo para ir ter com gente do 'outro lado"' $(2015$, p. 06).

Mais ao interior da morada, na parte posterior do hato nahi heha ("pátio da casa"), onde se situam a estruturas chamadas de ihira e onde se penduram as redes familiares, está a área mais reservada da casa chamada de nahi huxomi ou huxomihami, possivelmente traduzido por o "interior da casa", como uma oposição, portanto, ao hato nahi heha, o "pátio da casa". Essa área, que corresponde ao espaço familiar habitado pelos triângulos de redes e pelo fogo doméstico (como analisamos no capítulo "Tapiri"), se situa então mais ao fundo (huxomi) da estrutura da casa (nahi), entre a cumeeira do telhado - no caso das casas de duas águas ("ecléticas" ou não), ou na parte mais média deste, no caso das casas de com teto de uma água - e os fundos.

E, então, na parte traseira do espaço familiar, e especialmente nas casas "tipo tapiri" ou nas soluções contemporâneas e "ecléticas", onde o teto baixa quase até o chão, é onde se situa o último espaço, chamado de hato nahi xîka, "os fundos da casa" ou "o baixo da casa". Nesta área, seja colocado nas palhas da cobertura baixas do telhado ou no fechamento da pequena parede dos fundos, é onde costuma-se armazenar, de modo mais resguardado, objetos e coisas diversas de uso pessoal ou familiar (além do próprio espaço superior do ihira, o "jirau" sobre o triângulo de redes). É daí, também, que partem os caminhos que adentram à mata e saem, possivelmente, de cada uma das casas. Estes são acessados tanto por pequenos vãos ou portas no fechamento dos fundos da casa, mas, também, através dos próprios intervalos entre duas casas. Essas trilhas ligam as moradas às roças familiares, mas também aos igarapés e aos rios, aos caminhos de caça e aos caminhos que levam à outros xapono. Do lado externo, na área chamada de xîkaxîka a roxi, áreas de fronteira entre a floresta e os múltiplos caminhos que a adentram e o lado externo das casas do círculo do xapono, podem ainda ser complementadas com uma paliçada, afastada alguns metros dos fundos da casa e uma espécie corredor de passagem, feita com paus intercalados e fincados na terra ou com tramas de palha. O objetivo de tais paliçadas, menos comuns 


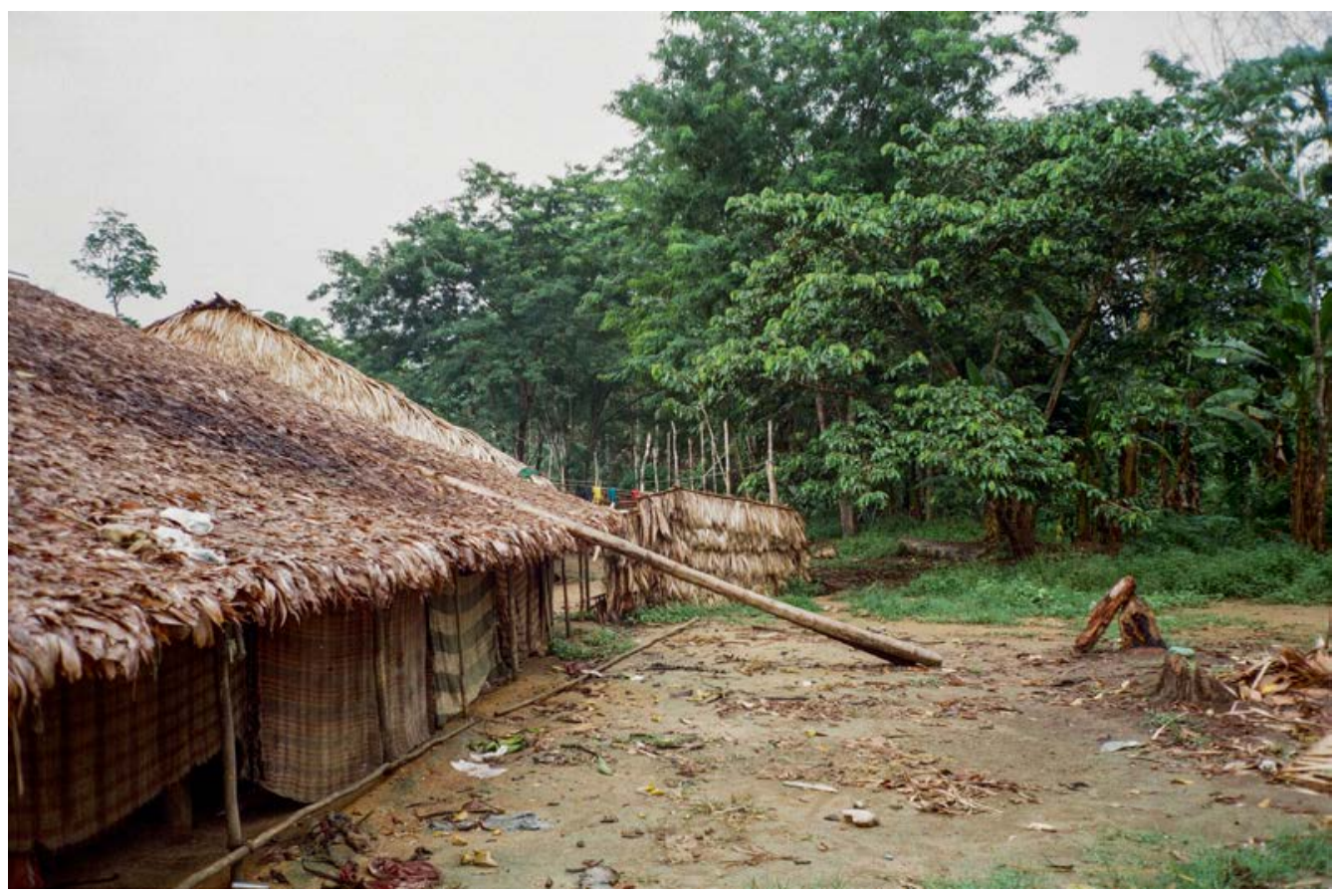

Fig. 45. Vista dos "fundos da casa" ou do "baixo da casa" (hato nahi xîka) no xapono Pukima Cachoeira (2019). Em primeiro plano, onde se situa a casa de Cândido e sua família, ainda em obras, notam-se os fechamentos temporários improvisados com tecidos e redes velhas e, mais aos fundos, um trecho de uma paliçada de proteção, feito com paus fincados no solo e palha. 
atualmente, é proteger os habitantes do xapono e das casas de eventuais ataques guerreiros ou, também, de ataques de espíritos maléficos ou de seres onkã.

Os onkã, "inimigos" potenciais e virtuais, são um outrem radical, violentos e monstruosos, estes andam em bandos e pintados de preto, mas, diferente dos hekura potencialmente perigosos, como ressalta Marielza Pukimapiwëteri do Pukima Beira, estes "são gente mesmo". Segunda ela, os onkã podem inclusive estar no próprio xapono, o que reforça o sentido mais geral de "inimigo", mas apenas nos xapono dos outros, presentes assim durante viagens para outras regiões ou comunidades potencialmente inimigas. Mesmo assim, os ataques acontecem no mato, especialmente à pessoas sozinhas e desacompanhadas e, após isso, somente o corpo destruído é encontrado. Os onkã , por sua vez, nunca estão sozinhos, mas sempre em grupo. Marielza disse já ter visto e descreve, especificamente, que eles possuem muitas pulgas nos pés, dando-lhes um aspecto repugnante. Contou que quando era criança, durante uma saída de wayumi, enquanto acampavam no mato, ela subiu em uma árvore, brincando com suas colegas, e ao escalar o tronco olhou para um caminho que dali saía e avistou um grupo de muitos onkã, pintados de preto com carvão (como a pintura guerreira) e adornados com braçadeiras de papagaio e rabo de arara. Desceu rápido da árvore e chamou a sua tia, mas ao voltar acompanhada estes já haviam desaparecido. Os ataques dos onkã são sempre brutais, quebram os ossos e o pescoço, esmagando-os com violência e o corpo cai no mato, morto. Assim, como conta Marielza, ao sair sozinho para o mato, sob o risco de serem atacados pelos onkã, os homens têm sempre de informar as suas esposas sobre os caminhos que irão seguir, para o caso de não voltarem ao xapono e serem resgatados, vivos ou mortos.

Dentre outras classes de perigos potenciais, como os diversos feitiços e venenos hëri, os onkã são costumeiramente citados pelos interlocutores do Marauiá como argumento pelo qual as casas são atualmente fechadas (os fundos, mas também as laterais e frentes), com fechamentos de palha trançada (curuá ou açaí, por exemplo), técnica chamada de tiëno tiëno ou yãtõrimano, ou de materiais diversos (ripas de paxiúba, tábuas serradas, pau-a-pique, dentre outros). Estes interlocutores ressaltam o "medo de onkã" que, potencialmente, coloca a família em risco, sobretudo, pois podem capturar e atacar suas filhas e filhos pequenos e "por isso a casa 
fechada e a porta", como me disse certa feita André do xapono Pukima Beira. Esse argumento, portanto, complexifica as leituras de que as casas yanomami passam a se fechar, com o tempo de contato e com diferentes soluções em diversas regiões do território, de acordo com o escolhas particulares relacionadas a preocupações com o aumento da posse de objetos de valor adquiridos com os Poowëteri, o "povo do machado" (ver, por exemplo, Reig, 2013, p. 177).

No entanto, não se deve descartar nas leituras sobre esses processos de transformação das casas uma interferência direta e violenta através da ação missionária. Se no Rio Marauiá esta nunca foi assim tão explícita dada à época e ao perfil dos padres que lá estiveram, mas também à falta de registro e documentação desse tipo de atitude-, na região do Maturacá, onde consta uma presença histórica mais intensa da missão salesiana, há registros da imposição de uma reorganização espacial radical. A partir de 1971, com a chegada de um novo padre italiano na missão, os indígenas foram forçados a deixar de habitarem as casas coletivas, associadas à práticas pecaminosas e imorais, e foram induzidos a viverem em casas unifamiliares, reclusas das demais por fechamentos laterais e cobertas por telhas de alumínio distribuídas pelos próprios salesianos (Menezes, 2010). Métodos análogos são compartilhados e por vezes abertamente expostos, ainda, por distintas missões e missionários em suas atuações com diversos povos indígenas. Relembremos a conhecida passagem relatada por Lévi-Strauss em Tristes Trópicos que descreve o modus operandi dos missionários salesianos entre os Bororo, no Brasil Central:

A distribuição circular das cabanas em torno da casa-dos-homens é de tal importância, no que se refere à vida social e à prática do culto, que os missionários salesianos da região do Rio das Garças logo aprenderam que o meio mais seguro de converter os Bororo consiste em thes fazer trocar sua aldeia por outra onde as casas são colocadas em fileiras paralelas. Desorientados em relação aos pontos cardeais, privados da planta que fornece um argumento a seu saber, os indígenas perdem rapidamente o sentido das tradições (Lévi-Strauss, 1996, p. 206-207).

Entre os Dessana do Alto Rio Negro, cujas icônicas malocas comunais foram praticamente extintas na década de 1950 pela atuação violenta, intensa e sistemática dos missionários, transbordam relatos de padres, bispos e monsenhores bradando contra as ditas "casa do diabo". Tidas como "perigosas", espaço da "promiscuidade", palco de "danças 
orgiásticas que duravam dois dias e duas noites seguidas" e do temível "gás carbônico" - argumento de caráter higienista utilizado em decorrência da fumaça das fogueiras acessas no ambiente fechado da maloca, apesar de eficientemente ventilada pelas portas frontais e traseiras, aberturas superiores e vãos dos fechamentos de palha, como relatado por diversos autores -, as primeiras iniciativas dos missionários concentram em destruir as moradas tradicionais e promover a construção de casas individuais, aos moldes (precários) da dita civilização, em suma, para "ser bonzinho, rezar sozinho" (Béksta, 1988).

Embora não se descarte o argumento materialista nos diálogos com os interlocutores do Marauiá, que apontam também os "furtos" e "sumiços" de materiais de valor monetário (motores, gasolina, ferramentas etc.), e também uma certa influência (ainda que mais indireta) missionária, vê-se com as narrativas dos seres onkã que a transformação dos fechamentos das moradas integra uma lógica ainda mais complexa e dinâmica (como também nota Reig, 2013, p. 160). Nessa, inclusive, outras razões são elencadas por variados interlocutores, como uma forma de evitar a proliferação de insetos (como os mosquitos piuns), de manter o calor do fogo durante as madrugadas frias ou de manter certa privacidade em relação às crianças do xapono ou às ávidas demandas de visitantes de outros grupos nas visitas intercomunitárias para efetuarem trocas. Mais do que uma simples decorrência do contato ou certa "caboclização", então, trata-se assim de uma transformação com múltiplas facetas e possivelmente variável, por exemplo, em função de um sistema sociopolítico e intercomunitário próprio (expresso através das trocas), mas também desde perspectiva xamânica e extra-humana (com a ameaça dos onkã). Além disso, mesmo quando as transformações decorrem de conflitos cotidianos (como os furtos), uma vez que estes não sejam bem atenuados, podem levar o grupo à eventual dissolução e mudança. Como diria o përiomí do Pukima Cachoeira, Adriano, originalmente referindo-se à obra e aos materiais demandados para o telhado da escola (hiramotima nahi, "casa da escola" ou a "casa do ensinar", como vimos no capítulo "Pendurar redes") em seu xapono, mas justamente a partir de uma analogia com a constituição da casa (yahi, nahi) yanomami:

Quando a casa por cima ficar diferente, o corpo continua do jeito que é. [...] Quando chegar o telhado eu não vou ficar diferente, não vou ficar com o corpo do homem branco, o jeito que nós nascemos continua. Dentro não muda de jeito nenhum. Mudou 
por cima, dentro não vai mudar. Nunca, nunca vai mudar.

Os fechamentos frontais, entretanto, podem gerar interferências significativas - embora nunca explicitamente notadas pelos meus interlocutores como um incômodo ou algo do gênero - no decorrer da festa funerária reahu ou no âmbito de visitas e outros grupos no xapono residente. Isso, pois, as danças praiai que permeiam estes encontros consistem, basicamente, em circular dançando e cantando pelo meio do xapono (xapono heha), fazendo pequenas paradas na frente de casa uma das casas e, assim, se exibindo, provocando e interagindo com seus moradores. Com isso, nas casas fechadas frontalmente, tais trocas são interrompidas e, mesmo assim, os visitantes-dançarinos mantêm as paragens, muito embora abreviadas. Tal interferência, portanto, transforma a lógica da visibilidade do meio do xapono (xapono heha), mas, como notamos anteriormente, certas casas recém-construídas no Alto Marauiá (especificamente, tal como notei, nos xapono Pukima Beira, Pukima Cachoeira e Ixima) têm inventado soluções alternativas (para uma discussão distinta mas sobre o mesmo problema da visibilidade, cf. Reig, 2013, p. 160). Dentre essas alternativas, algumas casas têm sido construídas com o fechamento frontal recuado, mantendo na soleira do meio do xapono uma área coberta e aberta, como uma espécie de varanda. Com este fechamento recuado, ao mesmo tempo em que se mantém um certo resguardo do interior das casas, conserva-se também a abertura para o exterior (ou o interior do xapono, no caso), o que permite que a área da morada conhecida por hato nahi heha, o "pátio da casa", seja reinventada e atualizada, seja durante o reahu ou, noutro contexto, durante as pajelanças hekuramou.

Essas transformações da morada que privilegiam o resguardo doméstico, desde a separação das casas em unidades menores até os fechamentos enquanto proteção contra seres extra-humanos potencialmente perigosos, podem assim ser pensadas como estratégias de reduzir conflitos inerentes à vida social da comunidade e da casaaldeia. Como nota Kaj Århem sobre os Makuna da Amazônia colombiana, a mudança das malocas para casas unifamiliares eram associadas como forma de “evitar os 'problemas' e 'tensões' (oca, literalmente, 'discussão', 'conflito') da maloca multifamiliar" (2001, p. 146) - mudança essa que era vista como uma nova forma de organização espacial e socialidade mas, ao mesmo tempo, padronizada de acordo com o modelo anterior da vida na 
maloca, de modo que a aldeia de casas segmentadas era vista e concebida, assim, como uma grande maloca, expandida e explodida (Århem, 2001, p. 150/151). Tal estratégia, então, refletia-se na consequente redução das friç̧ões entre ágnatos próximos e, com isso, atenuava as "tendências disruptivas da maloca" (Århem, 2001, p. 150), as "sementes da fissão [seed of fission] (...) inerentes à comunidade da maloca" (Århem, 2001, p. 146).

A reflexão de Århem ecoa também entre interlocutores do Marauiá que, em ocasiões distintas, me resumiam as motivações que os levaram a fechar as casas - movimento análogo à mudança da maloca para a casa unifamiliar - como forma de, em suma, propiciar "menos barulho", "menos briga" e "menos confusão". Tais estratégias ou transformações, portanto, buscam assim lidar com as configurações atuais do "padrão de agregação e desagregação" (Reig, 2013, p. 246) que configura a produção do espaço social yanomami. Mesmo assim, como argumenta Reig, as sementes da fissão, que este aponta como um "acúmulo intrínseco de tensão e excesso dessa configuração de socialidade", eventualmente tornam-se incontroláveis, atravessando os fechamentos e quaisquer outras estratégias espaciais ou materiais, de modo que "surgem conflitos que os forçam a se desagregar e a se mover, se re-agregando posteriormente em diferentes configurações e ciclicamente reiniciando a configuração de seus espaços" (2013, p. 246).

O mesmo argumento em torno do barulho - parte do trinômio "menos barulho", "menos briga" e "menos confusão", tal como citado acima - foi dito a mim por um interlocutor do Jutaí durante uma rápida paragem em seu xapono, no decorrer da viagem rio acima com o grupo do Pukima Beira em 2019. O xapono estava em obras e um jovem professor de lá, atento à nossa curiosidade, nos guiava pela reforma em andamento. O que nos chamava a atenção, entretanto, era o fato de que as novas casas que estavam sendo construídas na mesma área não só aumentavam o perímetro do círculo antigo de moradas, o que era de se esperar, mas, justamente, distorciam o formato circular da implantação das casas em um novo formato quadrangular, pré-configurado como em um projeto em escala real com estacas fincadas no chão marcando o local de implantação das casas em duas bandas do retângulo. Respondendo à minha indagação sobre o (suposto) novo formato, dizia ele que "quadrado é melhor, as casas ficam mais longes umas das outras" e, com isso, "têm menos barulho" e, por extensão, menos conflito, mais condições de permanência. Para 

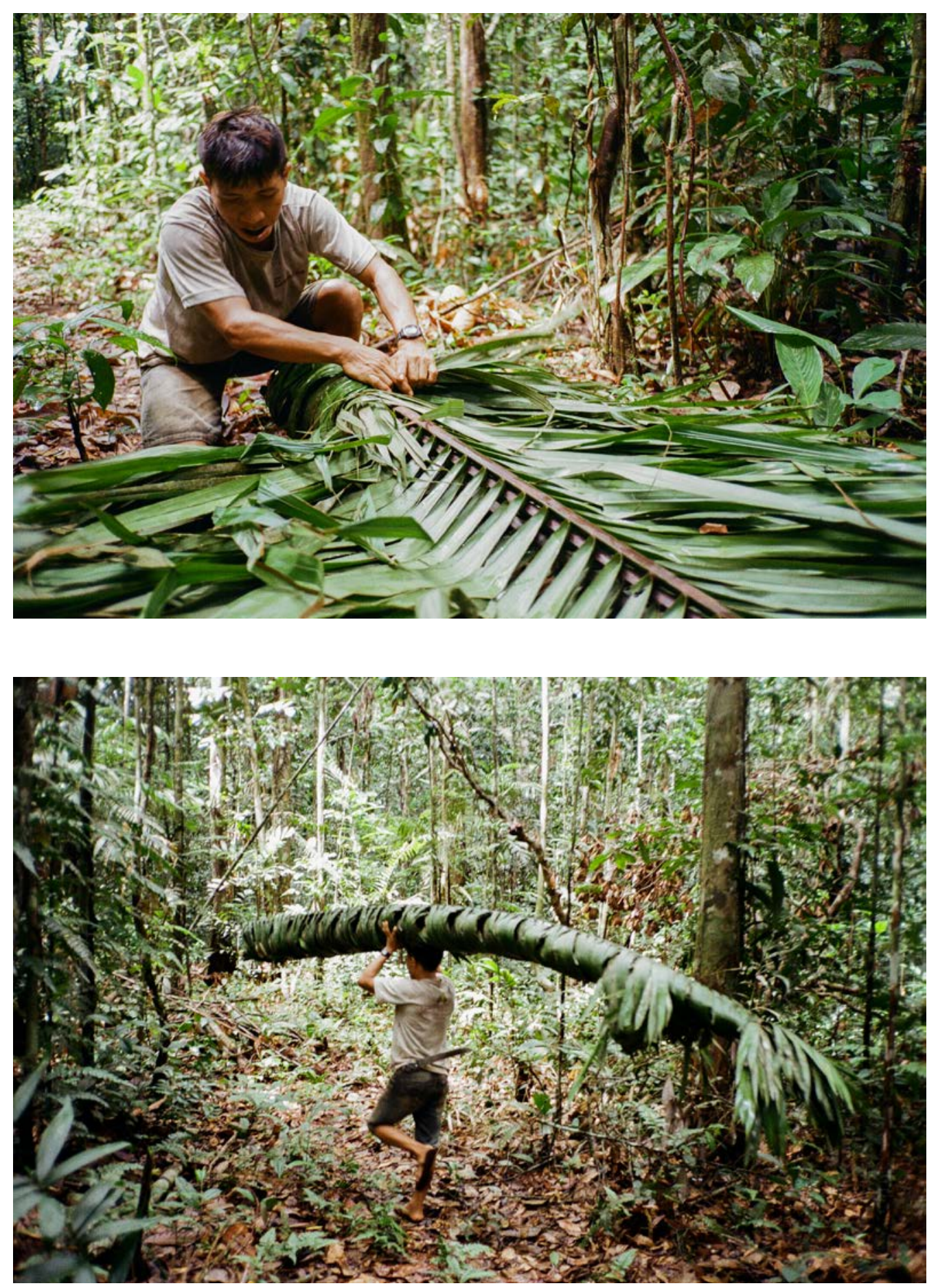

Fig. 46/47. Após o corte das folhas de curuá (yawatoa), em uma pequena clareira na mata, estas são montadas em feixe, como um peixe gigante, conforme nos ensinava Emerson, e carregadas ao xapono, onde serão utilizadas e trançadas para o fechamento de uma casa no xapono Pukima Cachoeira (2019). 

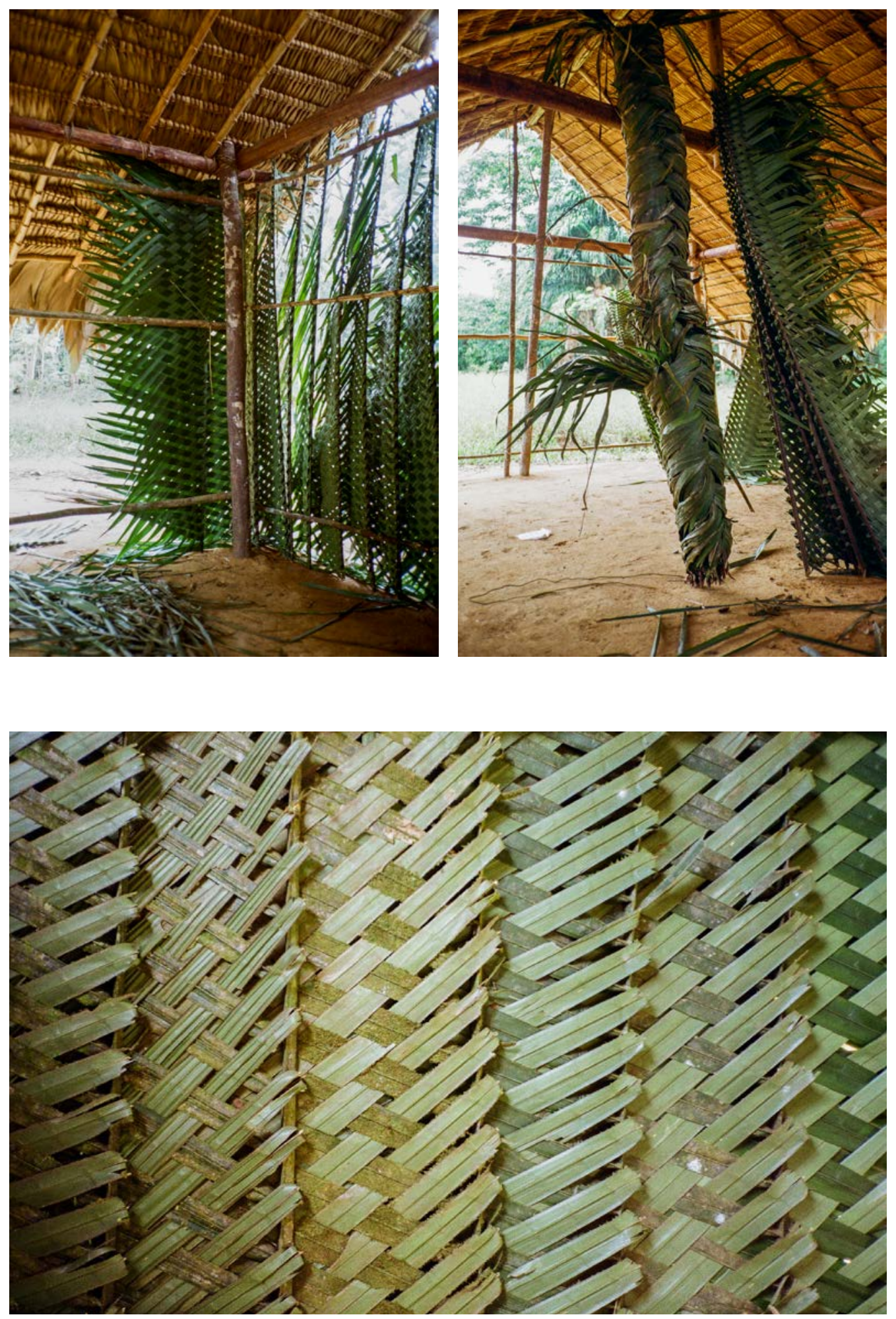

Fig. 48-50. Feixes de curuá (yawatoa)

trazidos da floresta e processo de trançado

do fechamento com palha em técnica

conhecido por tiëno tiëno ou yãtôrimano,

no xapono Pukima Cachoeira (2019). 


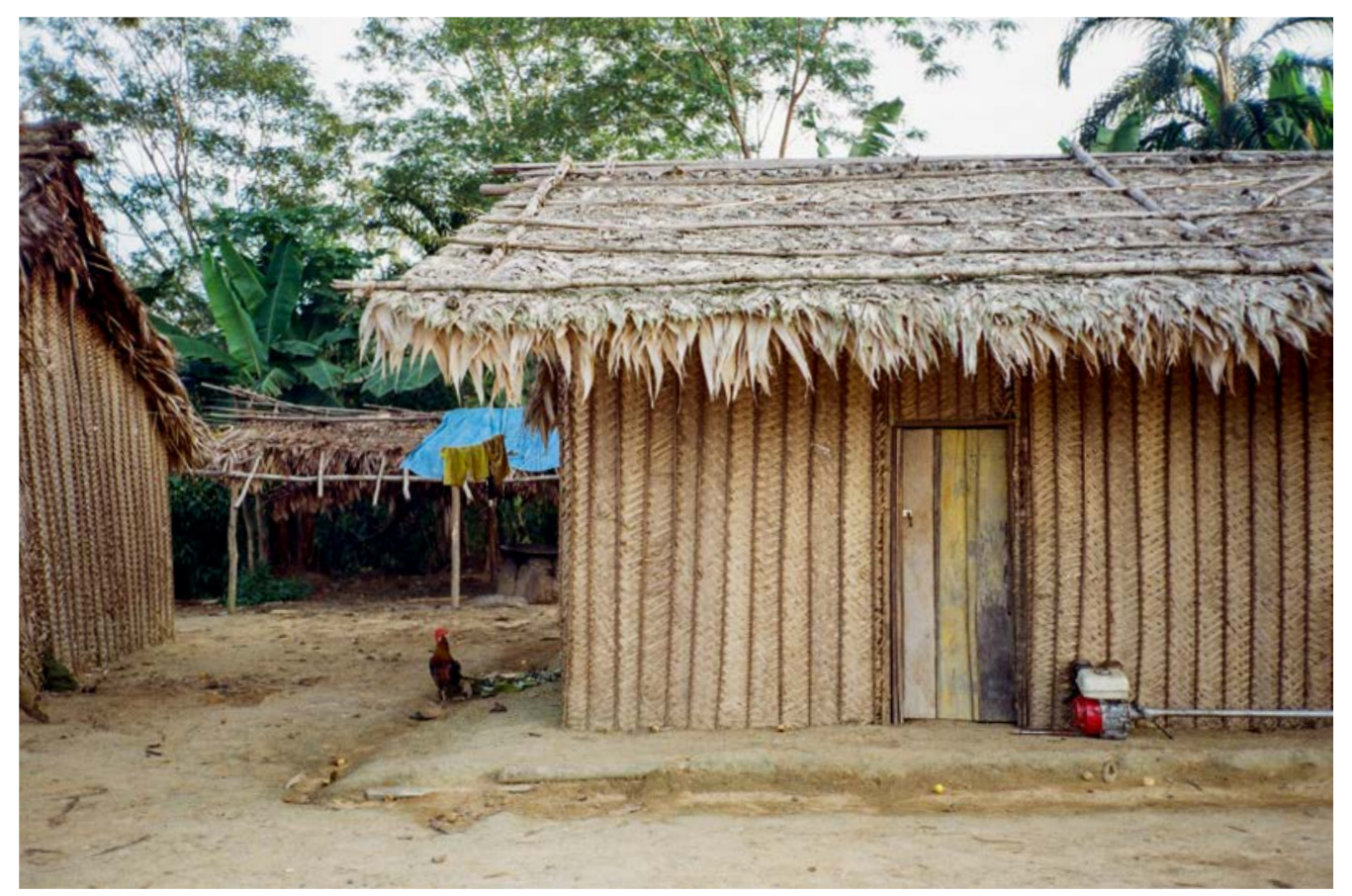

Fig. 51. Casa com todos os lados fechados com palha e porta reaproveitada do antigo posto de saúde no Pukima Beira (2019). 


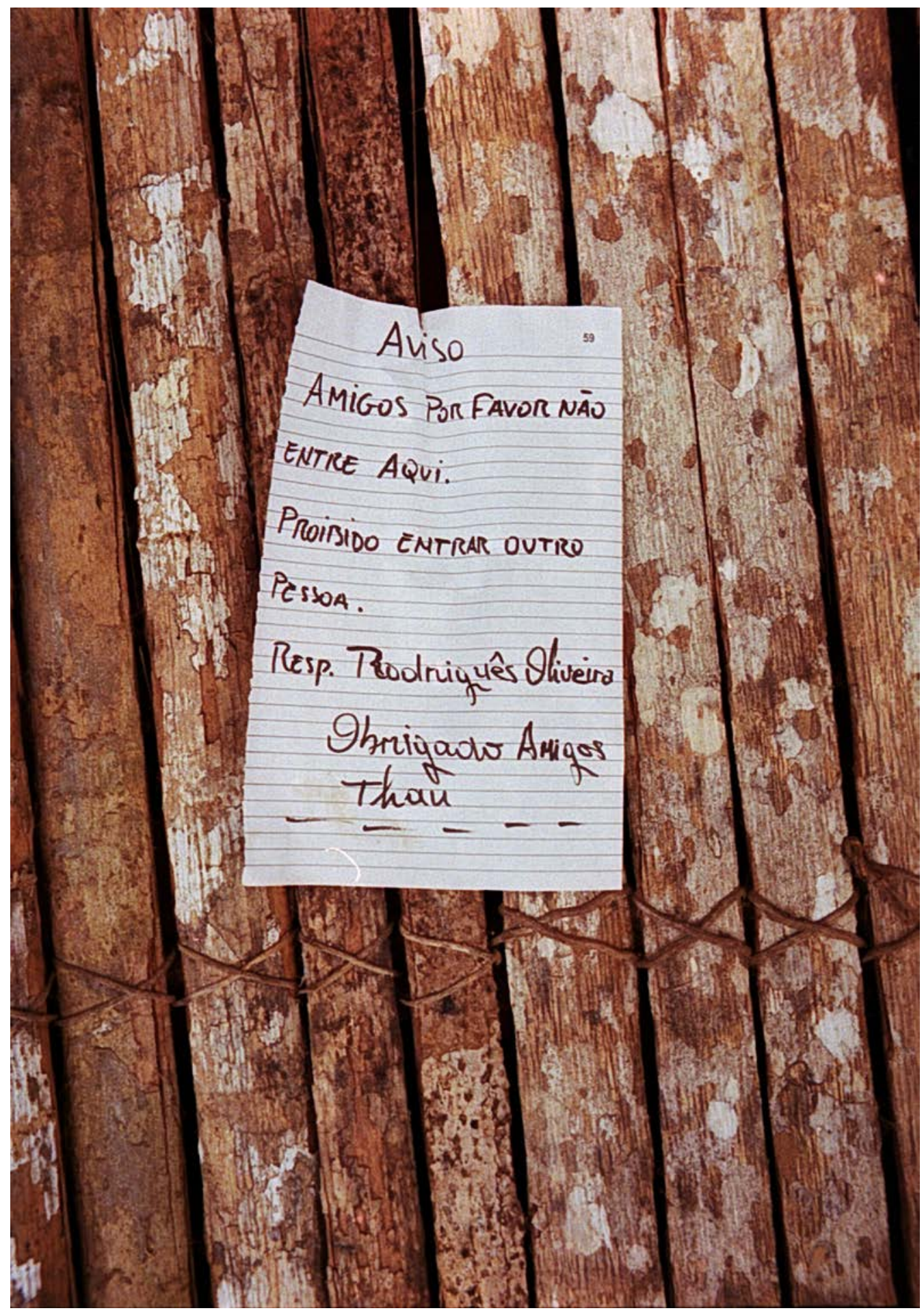

Fig. 52. Recado colado sobre fechamento ripado, ironizando as restrições de acesso tal como os napë fazem nas cidades, em uma casa no Pukima Cachoeira (2020). 
que as casas tivessem então um maior distanciamento, mais do que a forma, crescia também a escala do xapono, de modo que o novo traçado praticamente dobrava a clareira de tamanho, fazendo com que parte das novas casas se sobrepusessem aos roçados contíguos ao antigo círculo da casa-aldeia. Surpreendido também pelo tamanho da clareira e do trabalho envolvido, perguntei-o sobre a possibilidade de se mudarem num futuro próximo, ao passo que esse respondeu que, simplesmente, não pensam em se mudar, mas, pelo contrário, em "aumentar 1, 2, 3, 4, 5, 6, 7 vezes" o perímetro - agora quadrangular - das casas, expandindo-o para fora sucessivamente. Paralelamente, na mesma aldeia, mas fora do perímetro das casas, uma nova e grande escola estava sendo construída ao lado do posto, reforçando, assim, a intenção em ali permanecer.

Intrigado com a forma de ângulos retos - enquanto pensava que, de todas as transformações dos xapono no Marauiá, o círculo era uma constante -, os interlocutores do Pukima Beira e Cachoeira, quando assuntados por mim sobre tais práticas, sempre eram discretos ao extremo para tratar do assunto em relação, digamos, ao xapono dos outros. Dentre as respostas mais evasivas, dizer que "eles é que sabem" era, isso sim, uma constante - algo que, apesar da brevidade, reflete bem o regime de autonomia política de cada xapono e, com isso, evitava fofocas que, em certos casos, podem levar a sérios conflitos. Outro interlocutor do Pukima Beira, um pouco menos discreto, certa vez me disse: "Precisa ver bem de quem é esse pensamento, se é yanomami ou se tão colocando esse pensamento neles". E uma interlocutora do Pukima Cachoeira, disse: "Estão fazendo como na cidade". Ela mesma, no mesmo contexto, me atentou ao fato de que na língua Yanomami sequer há palavra para "quadrado", forma esta que eu me esforçava em explicar o princípio. A ausência, no entanto, difere da forma circular ou triangular, expressas na língua enquanto verbos de estado. Respectivamente, ximorewë, palavra utilizado para traduzir a forma geométrica "círculo", é um verbo de estado formado a partir da raiz verbal ximore- (com o sufixo de estado -wë) que enquanto verbo intransitivo, ximoreai, por exemplo, quer dizer "traçar um círculo, girar em torno de" (Lizot, 2004, p. 392). E turekewë, que traduz "triângulo", advém da raiz verbal tureke- que, como verbo intransitivo turekeait, significa "afinar" (Lizot, 2004, p. 431), sentido que se completa quando relacionado aos lados do triângulo que afinam em direção à ponta.

Ainda sobre o tal xapono quadrado, outro interlocutor do Pukima 
Cachoeira, o professor Mauro Pukimapiwëteri, explicou-me que, na verdade, os grupos que hoje habitam a região do Médio e Baixo Marauiá, derivados do antigo xapono Pohoroa (referido atualmente como Pohoroa Centro, assim como ao antigo Pukima Centro) - e com uma relação mais estreita com os missionários salesianos e mesmo com os napë pë da cidade, o que me levou naquele momento à hipóteses precipitadas sobre a passagem do círculo ao quadrado -, constroem suas casa-aldeias dessa forma há tempos, "desde o Hayanae". Segundo este interlocutor, tais formas de xapono assim "sempre existiram" e "os patapata pë já faziam assim antes", de forma que, com a reforma no Jutaí, todos os xapono derivados do antigo Pohoroa atualmente se configuram em formas quadrangulares.

Embora não sejam grupos dos quais estabeleci meu trabalho de campo diretamente, as variações formais desses xapono fazem pensar sobre os sentidos e as lógicas que configuram o xapono heha e o próprio xapono, em termos de sua morfologia mas, sobretudo, em termos daquilo que faz de um xapono, um xapono, de fato. Com isso, se não é o círculo de casas aquilo que permanece, fundamentalmente, através das múltiplas variações e transformações formais, o que poderia ser? A pergunta, de certa forma, é também um reflexo do modo pelo qual os modos de construir e habitar yanomami têm sido sistematizados e descritos na vasta literatura etnológica sobre esse povo que, de um modo geral, têm nas formas e expressões circulares do habitar, no mínimo, um destaque marcado. Em uma passagem da tese de Reig, por exemplo, a ênfase dada à circularidade do xapono se faz notável:

[...] a circularidade da aldeia permitiria dois tipos de inscrição [inscription] de atitudes e práticas sociais, uma fixa e a outra dinâmica: um olhar radial e concêntrico em direção à praça [o xapono heha, "meio do xapono"] e o outro ao yãno [no dialeto da região, equivalente ao termo xapono do Marauiá], em um registro sociopolítico, que fixa e controla o comportamento das pessoas posses e trocas; e um grande senso sociocósmico das trocas cíclicas entre os lares de parentes e aliados, entre as pessoas e outras pessoas e espíritos, predominantes após mudanças espaciais. Círculos, triângulos e esferas (e semiesferas) aparecem repetidamente como formas elementares de construção do espaço [space-building], apreensão e ordenação da vida social [apprehension and attitudinal ordering of social life] (2013, p. 194). 
Dito de forma abreviada, as ideias apresentadas por Reig em torno da "circularidade da aldeia" produzem relações interessantes entre a forma circular e os intrincados regimes de visualidade e de relações sociopolíticas que o xapono propicia. No entanto, sugiro que a partir da reflexão provocada pelos xapono quadrados Pohoroapiwëteri possa ser mais produtivo - e menos essencializante - compreender o xapono heha e o xapono em si para além do círculo como modelo físico ou geométrico, mas como um modelo conceitual.

A ideia, em suma, deriva do problema da circularidade levantado por Sylvia Caiuby Novaes em um estudo clássico sobre a arquitetura Bororo do Mato Grosso do Sul em que, de certa forma, atualiza a reflexão de LéviStrauss apontada em Tristes Trópicos sobre o mesmo povo e sobre o mesmo ponto, tal como mencionado anteriormente. Como indica a autora:

Se o contato com a sociedade envolvente forçou uma modificação na disposição das casas (funcionários da FUNAI construíram as novas aldeias, não levando em conta a disposição circular, os missionários tentaram interferir na organização social bororo, introduzindo a aldeia em ele) não chegou, no entanto, a alterar a forma pela qual os Bororo concebem a sua sociedade e a relação entre seus membros. É por isso que a forma circular continua sendo o modelo utilizado para expressar o modo pelo qual eles se representam. Mesmo quando situados em aldeias com casas dispostas em ruas, eles apontavam para as casas como se elas estivessem dispostas em círculo, descrevendo deste modo as relações sociais entre seus moradores (Novaes, 1983, p. 61).

Resguardada as particularidades sociais e históricas, o que o exemplo Bororo demonstra como interesse a esse trabalho é o modo pelo qual a circularidade, enquanto modelo das organização social e espacial, simultaneamente, excede a configuração física e geométrica e configurase como um modelo conceitual.

Entre os Sanöma, um dos subgrupos yanomami, por exemplo, as casas são geralmente construções retangulares, com telhados de duas águas, várias em número e dispostas de maneira aparentemente aleatória, sem uma orientação clara e definida e sem conformar os amplos terreiros circulares em seu centro. Nesse contexto, conforme Alcida Ramos:

Os rituais dos mortos, as discussões acaloradas, as grandes sessões xamanísticas, os debates interfamiliares e intercomunitários, os duelos e muita brincadeira de criança têm lugar no espaço fora das casas, transformado em 'praça' cerimonial sem contornos 
físicos bem delimitados (1990, p. 41).

Segundo informação verbal de Ramos, os Sanöma não possuem quaisquer registros de que chegaram a habitar casas coletivas circulares, cônicas ou troncônicas, embora em uma breve menção de Sílvia Guimarães em torno de uma narrativa mítica sanöma sobre a árvore dos cantos (tema transversal às narrativas yanomami no geral mas que não detalharei nesse trabalho), nota-se que “os antigos parecem fazer uma 'yano' ou 'xabono' ao redor da árvore, onde as famílias fazem seus fogos domésticos e no meio, onde está a árvore, acontecem os cantos e danças" (2005, p. 228, nota 51); e segundo Kenneth Taylor, os espíritos auxiliares dos pajés sanöma residem em "grandes casas comunais nos peitos dos xamãs" (1996, p. 145).

Na língua sanöma, o termo correspondente à xapono, "casa-aldeia", é sai a. Assim como em Yanomami o termo sai a não se restringe meramente à construção física das casas, mas à uma concepção de espaço alargada da casa-aldeia, aglutinando em si todos os demais níveis do espaço habitado dentro das clareiras: o compartimento familiar, a construção, o terreiro, a comunidade e a aldeia como um todo (Ramos, 1990, p. 62). No entanto, há uma interessante relação homófona - isto é, uma relação entre duas ou mais palavras que, sendo diversas no significado, se pronunciam do mesmo modo - entre o termo sanöma para a festa funerária e o termo yanomami para casa-aldeia: sabonomo (por vezes grafado também como xaponomou; cf. Taylor, 1996 apud. Ramalho, 2008, p. 148). O termo corresponde semanticamente ao termo reahu ("festa funerária") em yanomami e, também no sentido ritual, de um modo geral e apesar de pequenas variações, as festas seguem a mesma estrutura entre ambos subgrupos. Já na língua yanomami, xaponomou (note-se que /x/ e /s/ se assemelham fonologicamente) significa algo como "fazer, construir, reparar ou manter um xapono". Como vimos, o termo xapono não só se refere à construção e a estrutura da casa, mas ao conjunto dos espaços familiares, distribuídos em torno do vazio central, que compõem o grupo. Neste sentido, ao celebrar o morto e reunirem-se com os aliados, os Sanöma "fazem o xapono", "fazem a comunidade" (Ramalho, 2008, p. 148), de modo que para "além da celebração do morto, o termo sabonomo [xaponomou] enfatiza a necessidade de se reunir ou estar com outros [...]" (Guimarães, 2010, p. 115). Assim, sendo o reahu um momento de rememorar e esquecer ("por em esquecimento"; cf. Kopenawa; Albert, 2015, p. 670) o morto, mas também de selar alianças, resolver conflitos 

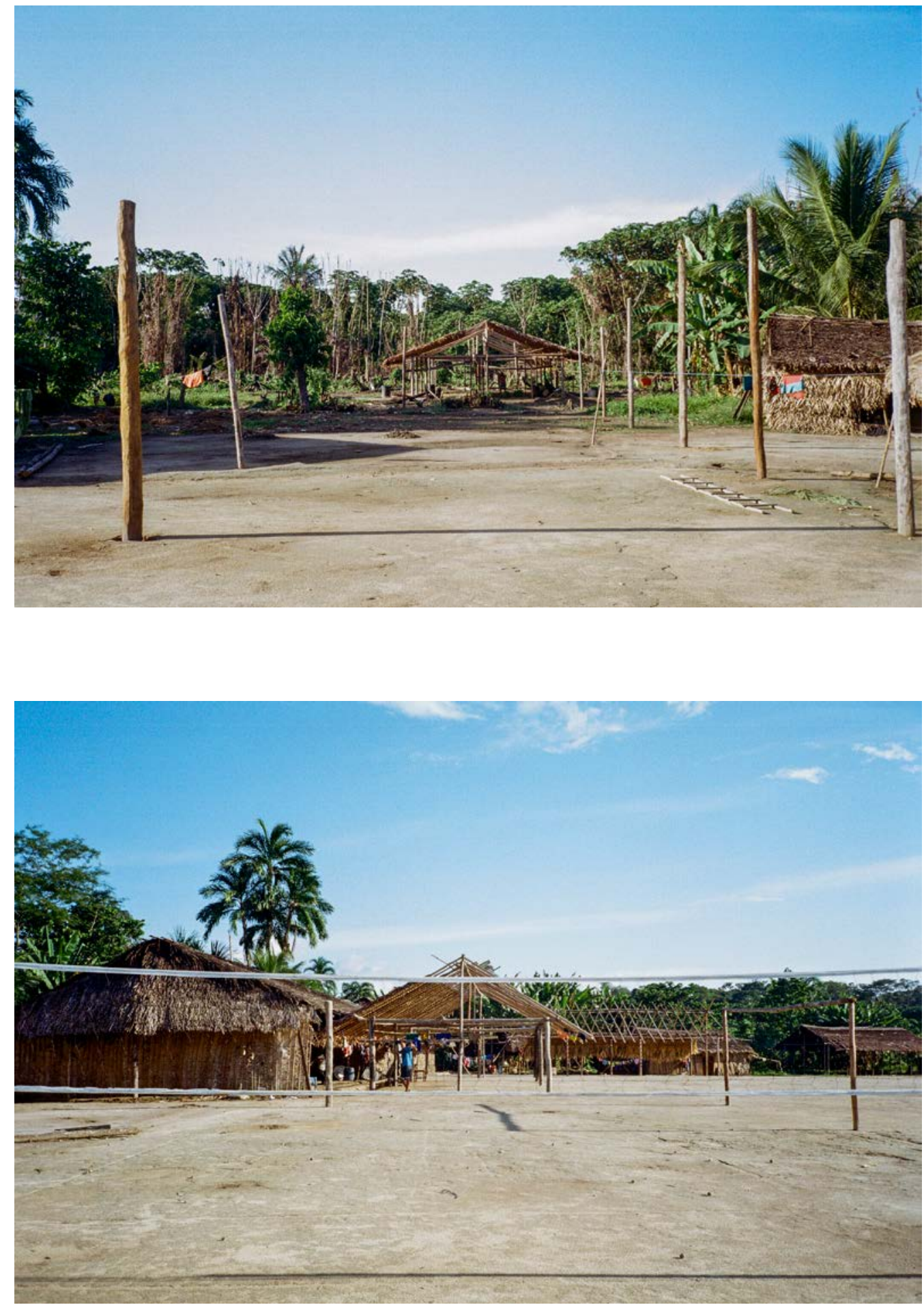

Fig. 53/54. Sobreposição das casas, ainda em obras e com os esteios marcando as futuras construções, dispostas com ângulos retos e em planta quadrangular frente às casas dispostas em círculo no xapono Jutaí do Médio Rio Marauiá (2019). 
familiares, engajar-se em novas relações afetivas e de criar ou reforçar a diplomacia entre as aldeias, o sabonomo (xaponomou), justamente, "faz o xapono" na medida em que reforça e consolida alianças, e assim faz, constrói, repara e mantem os grupos. Desse modo, de acordo com Ramos, ao "fazer o xapono" os Sanöma concebem para si o espaço cerimonial que "se algum dia existiu em suas vidas, hoje se deixa antever no imaginário do não-cotidiano" (Ramos, 1990, p. 43).

Com isso, proponho pensar o xapono não restrito a uma forma geométrica específica, mais ou menos circular, mas compreendendo-o como um modelo conceitual em que "meio do xapono" (xapono heha) opera como elemento lógico e relacional, gerador de sentido às múltiplas configurações da casa-aldeia e como aquilo que abre espaço, fundamentalmente, à sociabilidade yanomami. Atento à tradução feita pelos próprios Yanomami do termo xapono heha pode-se notar que mais do que uma forma política e geométrica em particular - como a noção de méson ("meio"), definindo o que é público em oposição ao privado, materializada no espaço geométrico e democrático da pólis pela cidade centralizada na praça da ágora (cf. Vernant, 2002, p. 252) - o que a tradução por "meio do xapono" sugere é um centro, não geométrico e nem vazio, mas um espaço intermediário entre as casas e as distintas seções familiares, marcado pela plenitude das relações inscritas no espaço. Essa plenitude, no entanto, é tanto produzida e mediada quanto entrecortada pelas relações de influência e de posição marcadas pelo parentesco e pela aliança, através da constante dinâmica de agregação e desagregação. Além do mais, trata-se de um espaço liminar entre as relações humanas e extrahumanas agenciadas pelos pajés, através do diálogo e do engajamento com os seres-imagem hekura. Nesse sentido que podemos compreender o xapono e o meio do xapono para além do círculo como modelo físico, isto é, para além de uma diferença extensiva e geométrica, mas como algo um modelo conceitual que permite uma reunião, de forma intensiva, em torno de algo e com alguém (reflexão que retomaremos no capítulo "Viver junto").

A diferença entre o extensivo (o geométrico) e intensivo (das relações, das afecções) do meio do xapono, contudo, se faz mais clara com este breve paralelo com o que propuseram Gilles Deleuze e Felix Guattari em Mil platôs:

Se há uma "geometria" primitiva (protogeometria) é uma 
geometria operatória [intensiva] em que as figuras nunca são separáveis de suas afecções, as linhas de seu devir, os segmentos de sua segmentação: há "arredondamentos", mas não círculo, "alinhamentos", mas não linha reta, etc. Ao contrário, a geometria de Estado [extensiva], ou melhor, a ligação do Estado com a geometria [ver, por exemplo, Lévêque; Vidal-Naquet, 1997], se manifestará no primado do elemento-teorema, que substitui formações morfológicas flexíveis por essências ideais ou fixas, afectos por propriedades, segmentações em ato por segmentos pre-determinados (2015, p. 97).

No entanto, diferente do que pressupõem Deleuze e Guattari, nesse caso, tratar-se-ia menos de uma protogeometria que de uma contrageometria, já que esta (a "primitiva") não antecede a outra (a "de Estado", democrática). O meio do xapono, ao contrário da forma fixa ou ideal, é potencialmente disforme, no sentido geométrico (ou contra-geométrico), mas não no sentido relacional. Neste, o xapono heha é, de certa forma, o negativo, o resultado (nunca concluso, mas contínuo), a expressão espacial das conjunções e disjunções, dos conflitos e das alianças, dos movimentos e da permanência, das contingências e das estratégias. Em torno do limpo da clareira, organizam-se as casas, não em oposição ao centro "público" e geometrizado (méson), mas ao redor do todo habitado. Como o revés da sombra habitada, é o meio iluminado o que contém o povo nele mesmo.

O caráter intensivo e luminoso do meio do xapono - seja nas variações menores ou maiores deste (análogas, em escala, a passagem de uma zenital à um pátio, e do pátio à uma praça) - tem também uma dimensão fundamental. Através dele, limpo (au) e claro (heruxi) - por vezes, insuportavelmente claro, quando muito limpo e muito iluminado pelo sol - é que são criadas as condições ou, literalmente, os caminhos para que os pajés estabeleçam diálogos e alianças com os seres-imagem hekura. Como me disse Adriano Pukimapiwëteri, um xapono pode ter diferentes formas, no entanto, o que não pode faltar ou, por extensão, o que faz de um xapono como algo de fato, é a presença dos pajés hekura: "Um xapono sem hekura é muito perigoso, vêm muita coisa ruim. O hekura cheira paricá e espanta as coisas ruins do xapono". Com isso, Adriano me explicava que sem os hekura, simplesmente, a permanência do grupo enquanto grupo, mas também num determinado local, seria impossível, insustentável dado o tanto de "coisa ruim" a que estariam sujeitos, sem o controle ou a mediação dos hekura. 


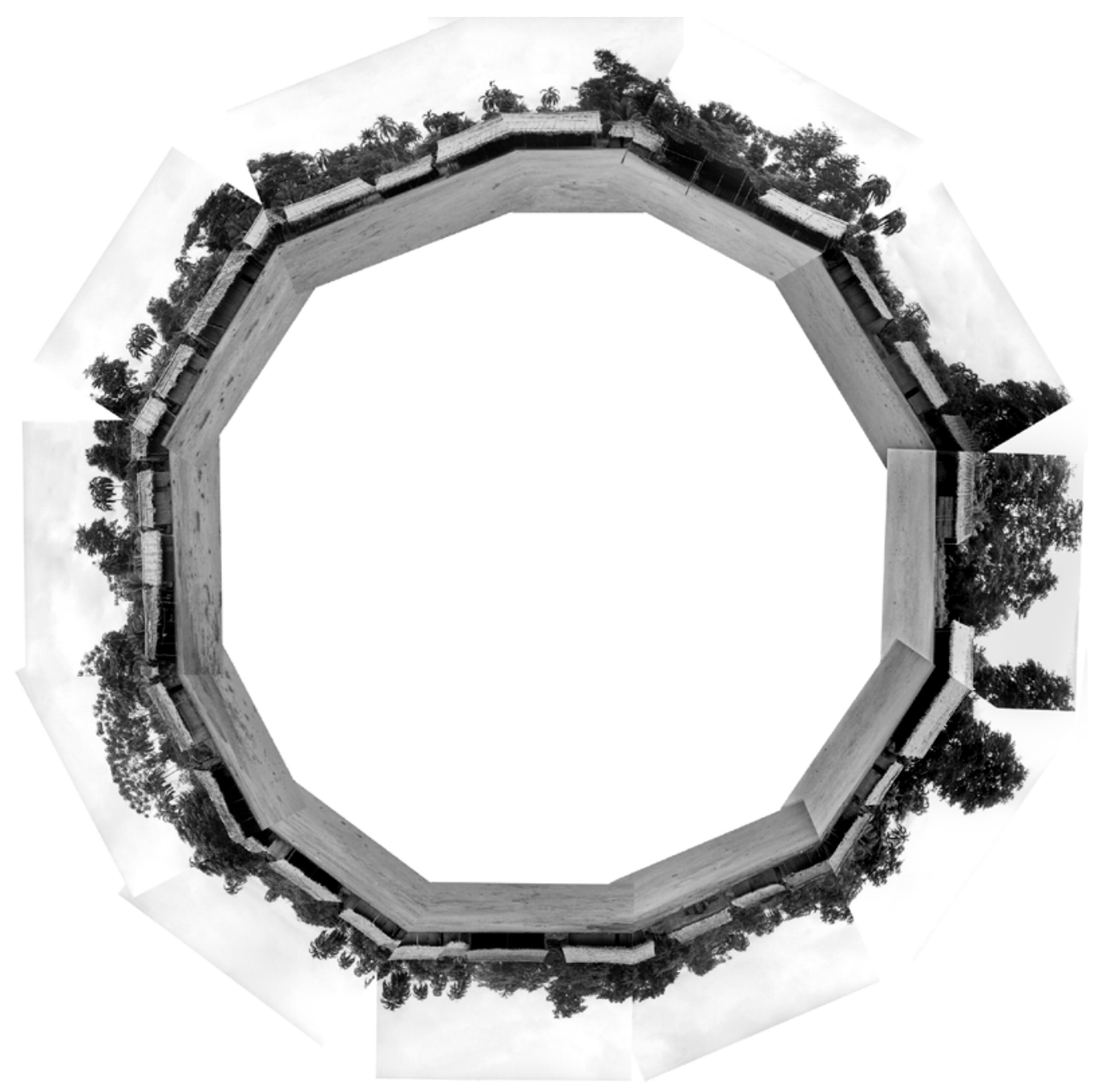

Fig. 55. Colagem com fotos tiradas desde o meio do antigo xapono Pukima Beira em 2016. O xapono havia sido recémabandonado pelos seus habitantes e as casas ainda estavam intactas, embora completamente esvaziadas e silenciosas. Com a imagem tem-se uma aproximação possível da perspectiva concêntrica do meio do xapono, da variação morfológica das casas e da dimensão da clareira central. 
Para que essa conexão entre os pajés e seus espíritos auxiliares se efetive, é o cuidado com a limpeza do meio do xapono que deve ser feito diariamente, já que os seres-imagem hekura têm completa aversão à sujeira. Essa limpeza, logo, deve ser feita pelos pajés que, como explicoume Adriano, "devem cuidar do meio do xapono para não espantar os espíritos; os hekura ["espíritos"] não gostam de cheiro de cocô". Assim, os pajés (mas não só) diariamente limpam as áreas defronte às suas casas ou às casas em que irão sentar-se para cheirar o paricá (epena) e cantar durante o hekuramou. Retiram cuidadosamente caroços de frutas, cocôs de cachorros, gravetos e impurezas diversas do solo, e também o varrem; com isso, desvelam uma camada de terra ainda mais limpa e mais clara. O brilho (herexi) do meio do xapono limpo (au) opõe-se, assim, a sujeira (ahi) e a escuridão (mi ruwë), tal como a da mata cerrada (paimi). De forma análoga, conforme descreve Pedro Cesarino sobre os Marubo da Amazônia Ocidental, a categoria shavá - cujos sentidos nessa língua pano abrange aspectos temporais (dias e épocas), espaciais (terreiro, casa, aldeia e espaço) e luminosos (claridade, luminosidade) - ressalta a dimensão fundamental dessa "forma de abertura no tempo-espaço para a existência luminosa em sociedade" (2019, p. 505). Em oposição à mata fechada (ni tsokoska) e à escuridão (vakíshka), associadas aos espectros dos mortos, o que a categoria shavá aponta é para centralidade da limpeza, do brilho e da luminosidade como condição para a socialidade, expressa de forma notável através da imagem da clareira na floresta: "imagem de um espaço que, aos poucos, oferecerá as condições para o estabelecimento daquela temporalidade marcada pela vida entre parentes" (Cesarino, 2019, p. 505).

A "espacialidade luminosa" da clareira da aldeia, assim, pode ser vista como condição para a socialidade e, também, como aponta Cesarino, para a capacidade de "estabelecer uma relação de extensão com os agentes que vivem em tais lugares [singularmente luminosos], com os quais um humano vivente pode eventualmente produzir relações" (2019, p. 506). Da mesma forma, através da limpeza do meio do xapono, tanto por um esforço coletivo na abertura de uma nova clareira quanto individual e que antecede uma sessão de pajelança, por exemplo, os reflexos da luz do sol intensificam-se e, através de tal luminosidade, permite-se assim que os hekura venham ou desçam, tornando-se, assim, visíveis aos pajés engajados no hekuramou. Como assinala Eduardo Viveiros de Castro: "a qualidade primordial da percepção dos espíritos é, assim, sua intensidade 
luminosa" (2006, p. 331). Essa qualidade se faz explícita também através das narrativas míticas, como essa coletada e traduzida por Ballester que diz: No início, havia os que ensinaram os Yanomami a morar. Os espíritos existiam e eram parecidos com os Yanomami. Os espíritos não foram obra de ninguém. Eram assim, como os Yanomami. O xapono deles era tão limpo como o meu, não era fechado. Moravam juntos. Dizem que moravam assim sem ninguém os ter ensinado. Eles viviam em um xapono igual ao meu. Eles andavam sempre no limpo. Eles faziam amizade, conversavam e se visitavam. [...] Se eles morassem ainda no limpo, todos vocês, rapazes, cantariam: ea, ea, ea! Todos vocês seriam pajés. Hoje, os espíritos não são mais visíveis, pois não moram mais no limpo. Eles dançavam, faziam festas no limpo, como os Yanomami. Eles dançavam como dançam os Yanomami, no limpo (Ballester, 2017a, p. 109-110).

Assim, não só a limpeza é ressaltada como uma característica primeira do xapono e do xapono heha como, também, é uma marca distintiva entre os tempos da visibilidade completa (anterior a distinção entre os seres visíveis e invisíveis, os hekura) e das condições ideais para se tornar pajé (através da habilidade de ver os espíritos). E como me disse Cândido, pata hekura do Pukima Cachoeira, o limpo terreiro à frente de sua casa, caminho pelo qual os hekura passam, ainda longe de tocar o chão, é limpo como "uma pista de pouso", onde, segundo traduziu seu filho Claudio, é onde "fica o seu avião, bem na frente da casa dele". É "como um aeroporto", e de lá, com ele, "ele consegue ir longe, para muitas cidades e muitas outras moradas", traduzia Claudio. Por isso que, diziame Cândido, quando eu o via em sonho, era ele mesmo, pois ele conhece muito e, por isso, pode ir muito longe.

A limpeza, entretanto, desvela outra característica complementar do xapono, a experiência luminosa. Em outra passagem da mesma narrativa, conta-se sobre o xapono mítico que: "Apesar de ser um xapono, ele era muito brilhante, como um espelho, possuía uma luz própria" (Ballester, 2017a, p. 112). Esta imagem do xapono de luminosidade extrema, ao mesmo tempo em que como o lugar limpo onde quem moraria logo tornarse-ia pajé, relaciona-se também com o relato de dois interlocutores pajés do Pukima Cachoeira, Francisco e Claudio, ambos irmãos de Adriano e filhos iniciados por Cândido. Contou-me Cláudio que ao cheirar o epena, o hekura vê, durante o hekuramou, o xapono através de uma intensa luminosidade: "As casas, todas, com muitas cores, como um arco-íris". 


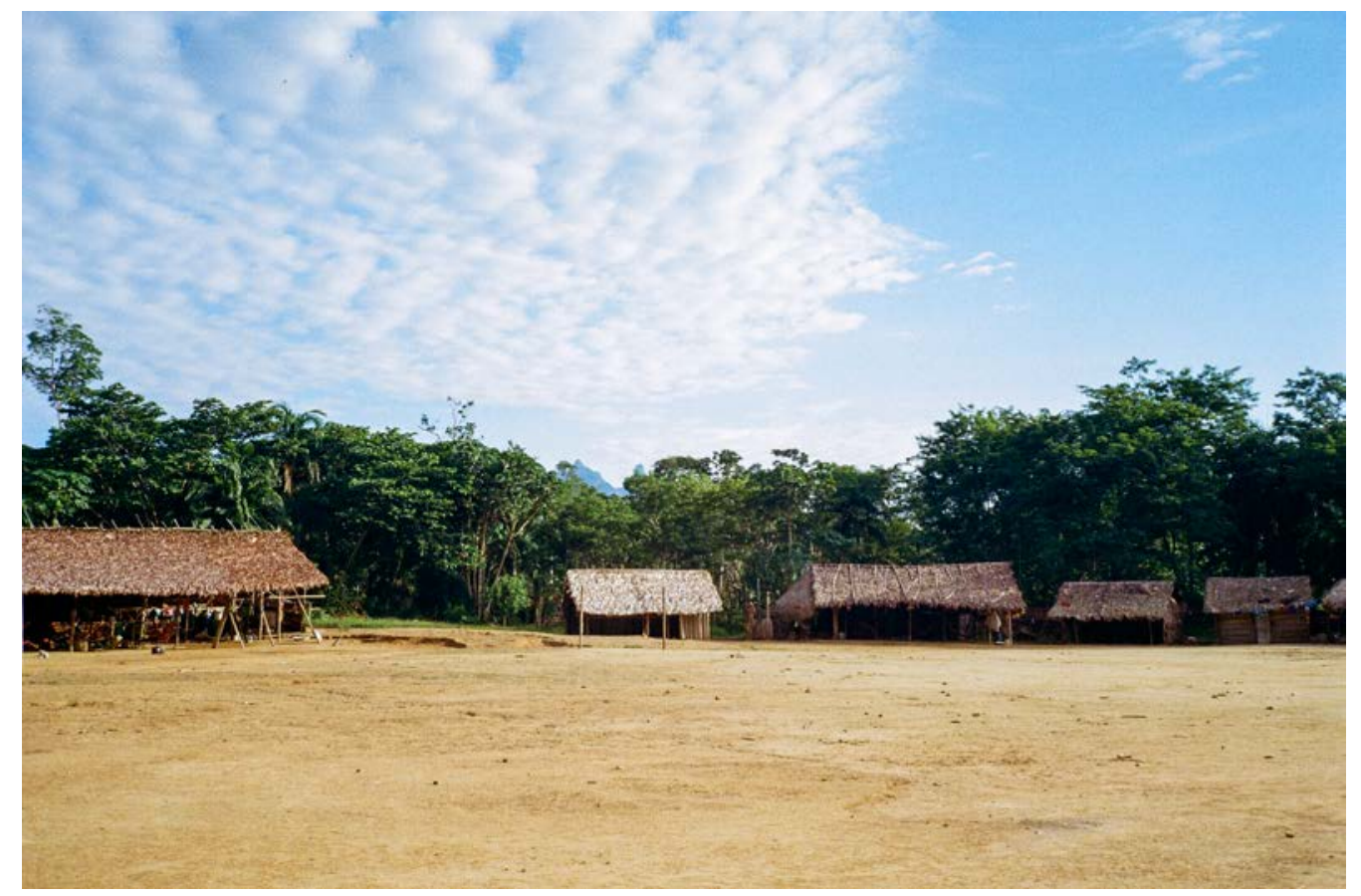

Fig. 56. Pukima Cachoeira, visto do meio do xapono, de onde se vê a serra e os picos rochosos (pei maki) ao fundo (2019). 


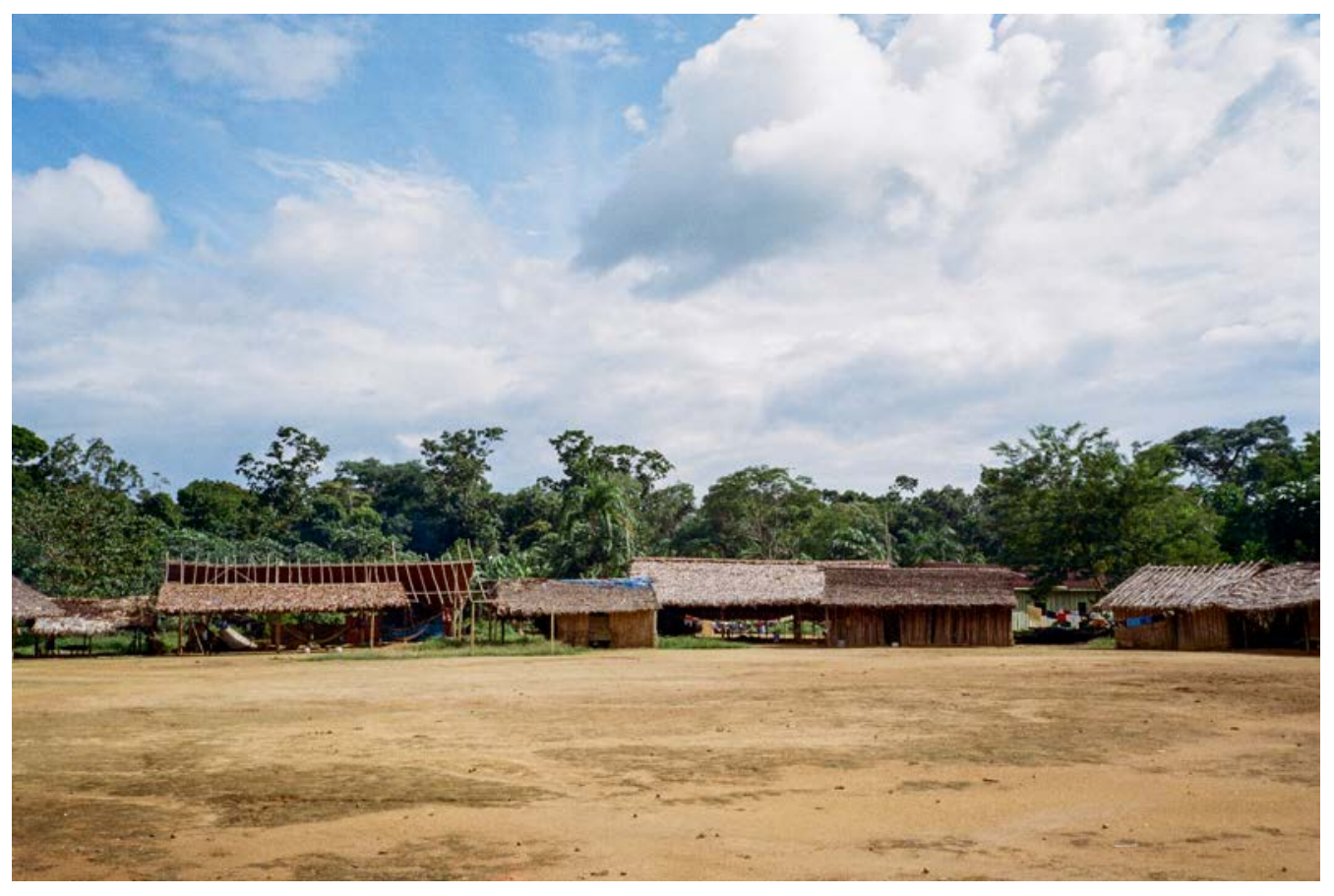

Fig. 57. Pukima Cachoeira, visto do meio do xapono, mas voltado ao outro lado. Ao fundo, atrás das pequenas casas improvisadas, a casa tipo "eclética" de Moisés (2019). 
E Francisco, diz que de tão brilhante, luminoso, limpo e colorido, "você pensa até que vai escorregar de tão liso". Diz também que ao longo do hekuramou, desde a o processo de iniciação xamânica, a experiência visionária é como "fogos de artifício ou flashes de câmeras fotográficas". Segundo Francisco, durante a iniciação a intensa luz, e com ela os hekura, vêm por cima da cabeça do pajé que lhe inicia, "como se tivesse ali uma tela de TV; dá medo". Diz, ainda, conforme lhe contava Cândido, que se ali, no espaço do hekuramou, "tiverem fotógrafos escondidos, vai queimar a câmera deles".

O conhecimento dos pajés, assim, é mediado pelo brilho intensivo dos caminhos dos hekura, estes que adentram o xapono heha vindos desde uma luminosidade extra-humana, transformando o espaço do terreiro. Como indica Viveiros de Castro - cujo argumento expande-se dos yanomami para os povos indígenas amazônicos -, a relação entre iluminação e conhecimento, entretanto, não trata "de uma concepção de luz como distribuindo relações de visibilidade-cognoscibilidade em um espaço extensivo [...], mas da luz como intensidade pura, coração intensivo da realidade que estabelece a distância inextensa entre os seres - sua maior ou menos capacidade mútua de devir" (2006, p. 332). Através da luz, em sua maior potência, a capacidade de devir. E através do meio do xapono, limpo e brilhante, o caminho ao invisível e à multiplicidade intensiva própria dos hekura. Como sugere Viveiros de Castro, entrelaçando enfim sentidos aqui expostos da limpeza, da luminosidade e, também, da visibilidade (e seu oposto) dos seres-imagem:

[...] Aquilo que é normalmente invisível é também o que é anormalmente luminoso. A luminosidade intensa dos espíritos indica o caráter super-visível destes seres, que são 'invisíveis' ao olho desarmado pela mesma razão que a luz o é - por ser a condição do visível (2006, p. 332).

Um xapono com hekura, então, é um xapono pei a yai, "uma casaaldeia verdadeira", conforme me explicou Adriano. Isso, por exemplo, se vê quando falece um grande pajé (pata hekura). E ali onde este é queimado, em uma grande fogueira no meio do meio do xapono, é colocado um pau, de madeira dura e adornado na ponta com penas de rabo de arara e montes de penas de papagaio, pintado de urucum, todo desenhado de linhas sinuosas e pontos intercalados e, ao fim, emplumado com penas brancas de gavião. O pau ali fica, como uma estaca pouco maior que uma pessoa, no meio do xapono, até que no aniversário de sua morte, com 
os adornos já desgastados - carcomidos pelo tempo, porém intocado -, pode ser refeito e re-enfeitado. Assim como o que se usa no taamayõu, a iniciação xamânica, este pau é chamado de pei makí, palavra que indica tanto as "rochas", "montanhas", "picos rochosos" como, também, as "casas dos espíritos" (como veremos no capítulo "Casa-montanha"). E como explica Adriano, "o pei maki indica que aqui tem casa de espíritos". É um xapono verdadeiro. 

III

\section{Viver junto}

Cuando la noche llegó a su fin, los ruidos de la mañana reemplazaron a los de la noche, y los ancianos ordenaron:

-iHijos, levántense! iYa es de día! iVáyanse a cazar, a matar presas!

Fragmento de mito narrado por interlocutor Karohiteri

(Lizot et al., 1993, p. 82)

Contam os pajés Parahiteri sobre uma grande liderança chamada Koparisini, o ancestral Gavião (gavião-azul, Buteogallus schistaceus). Dizse que foi ele quem "dividiu a terra onde nós moramos" e, além disso, foi ele quem "ensinou a morar" na região "onde eles [os ancestrais no patapi] moravam antigamente" (Ballester, 2017a, p. 17). A perspectiva sobre o morar, expressa através do mito, é digna de nota. Segundo registrado por Anne Ballester, conta-se que "nessa terra ele [Koparisini] fazia o kãwãamou e transmitiu esse ritual; ele os mandava se reunirem e nos ensinou, assim, a nos reunirmos em nosso xapono" (2017a, p. 17). O kãwãamou (ou patamou, literalmente "agir como um velho/ancião"), transmitido para os Yanomami pelo ser-imagem Gavião (Koparisini), consiste em uma prática cotidiana na vida social. Nela, o falante dirige o discurso ao povo do xapono para estimular e organizar atividades comuns, mas também para compartilhar notícias, planos e conflitos. O kãwãamou é feito no espaço da aldeia, o xapono, mas também em acampamentos temporários na floresta, osyãno, em expedições de caça e coleta coletiva wayumi ou durante viagens pela mata, de modo que pode ser reproduzido sempre que o grupo se encontra junto, em suma. Essa prática pode ser considerada uma variante das falas de chefe ameríndias, ainda que não seja necessariamente restrito aos chefes ou líderes de facção familiar, os përíomí. A fala dos chefes e dos patapata pë, entretanto, são as mais reconhecidas como "falas boas" e "falas fortes", já que articulam melhor o ritmo e o estilo próprio do kãwãamou, além de terem mais conhecimentos das histórias do tempo dos 
antepassados, sendo que são essas que estabelecem os parâmetros para organizar as atividades do grupo. Patapata pë, a saber, pode ser traduzido, assim como é feito no Marauiá e aqui nesse texto, por "velho" (patayoma, "velha"), bem como por "ancião/anciã", "grande homem/mulher" e, como dizem, "os postes da casa"; velho/velha, no entanto, estão mais associados à sabedoria e ao conhecimento e menos à idade.

Como conta Davi Kopenawa, é comum que os velhos, inclusive, não deem nenhuma instrução durante o kãwãamou (hereamuu, na língua yanomam), mas apenas discorram "com sabedoria" e "falam somente para que seus ouvintes possam ganhar conhecimento", nomeando os antigos feitos e todas "as antigas florestas onde seus pais e avós viveram, descendo aos poucos das terras altas” (2015, p. 382). Já os pajés, conta Kopenawa, falam sobretudo do tempo dos antepassados anterior à distinção humano-animal e costumam dizer assim: "No primeiro tempo, nossos ancestrais viraram outros, transformaram-se em veados, antas, macacos e papagaios" (2015, p. 382). Dessa forma, narram as histórias antigas e "é assim que ensinam as coisas para as pessoas comuns; para as pessoas que não conhecem os ancestrais animais, nem todos os mundos distantes, cujas imagens não são capazes de fazer descer" (Kopenawa; Albert, 2015, p. 383).

Noutra série de narrativas míticas, como indicado por Javier Carrera Rubio (2004), a origem do kãwãamou é também associada a origem da noite, inaugurada pela morte de Titiri - o "demônio da noite" associado ao antepassado mítico do mutum (Crax alector) - por Horonami, o "primeiro dono da floresta" (Ballester, 2017b, p. 20). "Dono" em Yanomami pode ser indicado através do mesmo sufixo -teri que, como vimos anteriormente, pode significar também o "habitante de" ou "povo de", determinando o xapono ou o grupo local daquele a que se refere, como Wãhaawëteri. Num sentido mais cotidiano -teri é então posposto ao objeto, como mokawateri - mokawa, "espingarda" -, o "dono da espingarda". Nesse sentido, o sufixo indica, ao que parece assim como no uso relacionado ao grupo local ou local de moradia, algo que forma parte de um conjunto maior, mas que, nesse caso, está relacionado a alguém em específico. Já ao se referir a um personagem mítico ou espírito auxiliar xamânico um ser-imagem dos tempos primeiros - "dono" pode ser indicado como porewë, como em Iwariwë kã̇ wakë porewë, "Jacaré (o ser-imagem, dado o sufixo "espiritizador" -riwë em iwa, jacaré) dono (porewë) do fogo (kã̇ 
wakë). Ou ainda, tal como traduzido por Ballester como "a história do primeiro dono da floresta [Horonami]" (2017b, p. 20), urihi a rë ponowei të ã, onde o "dono" é indicado pela raiz verbal pou ("possuir", "ter", "guardar"), conjugado aqui no sentido de "aquele que possuía" (-nowei) e possivelmente traduzível, de modo mais literal, como "a história daquele que possuía a floresta". Nos últimos dois casos, sobretudo, o idioma da propriedade privada é equívoco e no lugar deste é o idioma do donomestre - constituinte da socialidade amazônica (Fausto, 2008) - que define seus contornos principais. Nesse sentido, cabe a Horonami, não a simples posse, "mas sim as capacidades de conexão com o campo virtual de saberes, baseadas nas tarefas de citação, mediação e transmissão" (Cesarino, 2010, p. 162) e, no âmbito desse modo generalizado de relação propriamente indígena e amazônico, a capacidade de gerar uma "ação eficaz sobre esse mundo" (Fausto, 2008, p. 330), como veremos a seguir.

Em uma das versões do mito conta-se que foi Horonami que "procurou aquilo que nos permite dormir. [...] Ele procurou sem desistir, procurou, procurou e acabou encontrando essa coisa perto de sua moradia. A cauda da coisa já estava visível, pendurada em um galho [...]. A noite estava empoleirada em cima de uma árvore não muito distante. Parecia com um mutum empoleirado [...]. Assim era a escuridão. Apesar de a noite parecer um mutum, Horonami conseguiu encontrá-la. A noite também cantava como um mutum. [...] Quando Horonami flechou o mutum da noite, apesar de estar perto da sua moradia e de retornar correndo, ele também sofreu, porque anoiteceu de uma vez. [...] Naquela noite, os Yanomami também sofreram. [...] Havia então três pajés: o avô, o avô mais novo e o cunhado, e eles esquartejaram a noite, fazendo reaparecer a luz do dia [...]" (Ballester, 2017b, p. 17-20). E em outra versão, registrada por Jacques Lizot, a narrativa termina assim: "Quando a noite chegou ao fim, os sons da manhã substituíram os da noite e os velhos ordenaram: ‘Jovens, acordem! Já é dia! Vão pro mato, vão caçar!"' (1993, p. 82).

Com o fim da primeira noite, esquartejada pelos pajés (numa versão) e anunciada pelos sons da manhã vindos da floresta (noutra versão), o crepúsculo da manhã é também acompanhado das vozes dos velhos, substituindo os roncos da noite e orientando os mais jovens a despertarem e irem para o mato. Na transcrição original do mito em yanomami, recuperada e analisada por Carrera Rubio a partir da versão registrada por Lizot, é notável que a fala dos velhos patapata pë que encerra 
a narrativa, reproduzida em discurso direto, remete precisamente ao estilo da retórica típico da abertura dos diálogos kãwãamou (Carreira Rubio, 2004, p. 49/67): "ihiru pë, / pë ta hokëtou haitaru!” [“jovens, / acordem já!" ou "meus filhos, / acordem já"]. Como pontua o autor, a orientação dos velhos para que os jovens despertem e saiam para caçar pode parecer óbvia, mas tratando-se de um período anterior a estabilização do tempo e, portanto, do cotidiano e das normas sociais e morais, a fala do primeiro kãwãamou orienta o desenrolar da vida social ao passo em que explicita o valor da palavra, especialmente a dos velhos na alvorada do dia (Carreira Rubio, 2004, p. 68). E assim como "a noite também cantava como um mutum", o amanhecer passa a falar, num certo sentido, como um velho.

Kopenawa conta que "para ser capaz de proferir os discursos em hereamuu [mq. kãwãamou] com firmeza, é preciso conseguir a imagem do gavião kãokãoma [falcão-cabure, Micrastur ruficollis], que tem uma voz potente" (2015, p. 381). A imagem, ou o ser-imagem, gavião kãokãoma é conhecida entre os Yanomam (subgrupo de Kopenawa) como Kãomari. Segundo Kopenawa ela desce "por conta própria, não é preciso ser xamã" e, assim, transmite suas afecções para o falante: "Ela indica à nossa garganta como falar bem. Faz surgir nela as palavras, umas depois das outras, sem que se misturem ou percam sua força. [...] Com ela, nossa língua fica firme, não falha [...]" (2015, p. 381). Falar bem, nesse contexto, refere-se à sabedoria de proferir exortações longas, potentes, vigorosas e efetivas, mobilizando o povo do xapono para as atividades diárias e, além disso, transmitindo conhecimentos antigos e dos antepassados. É através de uma "ética da dialogicidade" (Cesarino, 2020, p. 07) própria, então, que se sustenta o jeito correto de viver, como narra o mito de origem da noite.

Entre os Yanomami a mesma espécie de falcão apontada por Kopenawa é conhecida como kãwãmãri ou kãõmãri - daí o nome, kãwãamou. O sufixo -mou (assim como -muu em yanomam), como vimos, transforma o substantivo em verbo e, nesse caso, poderia ser traduzido como "agir como um falcão-caburé". A correspondência da espécie entre a fala de Kopenawa sobre a imagem de Kãomari e a raiz do termo kãwãamou é notável. O falcão-caburé, conhecido mais pelo seu chamado do que realmente é visto, costuma repousar quieto e solitário empoleirado no interior da mata e não costuma fazer sobrevoos. O seu chamado, entretanto, se assemelha com um latido agudo e é emitido especialmente no início da manhã e no fim do dia, assim como o kãwãamou. 


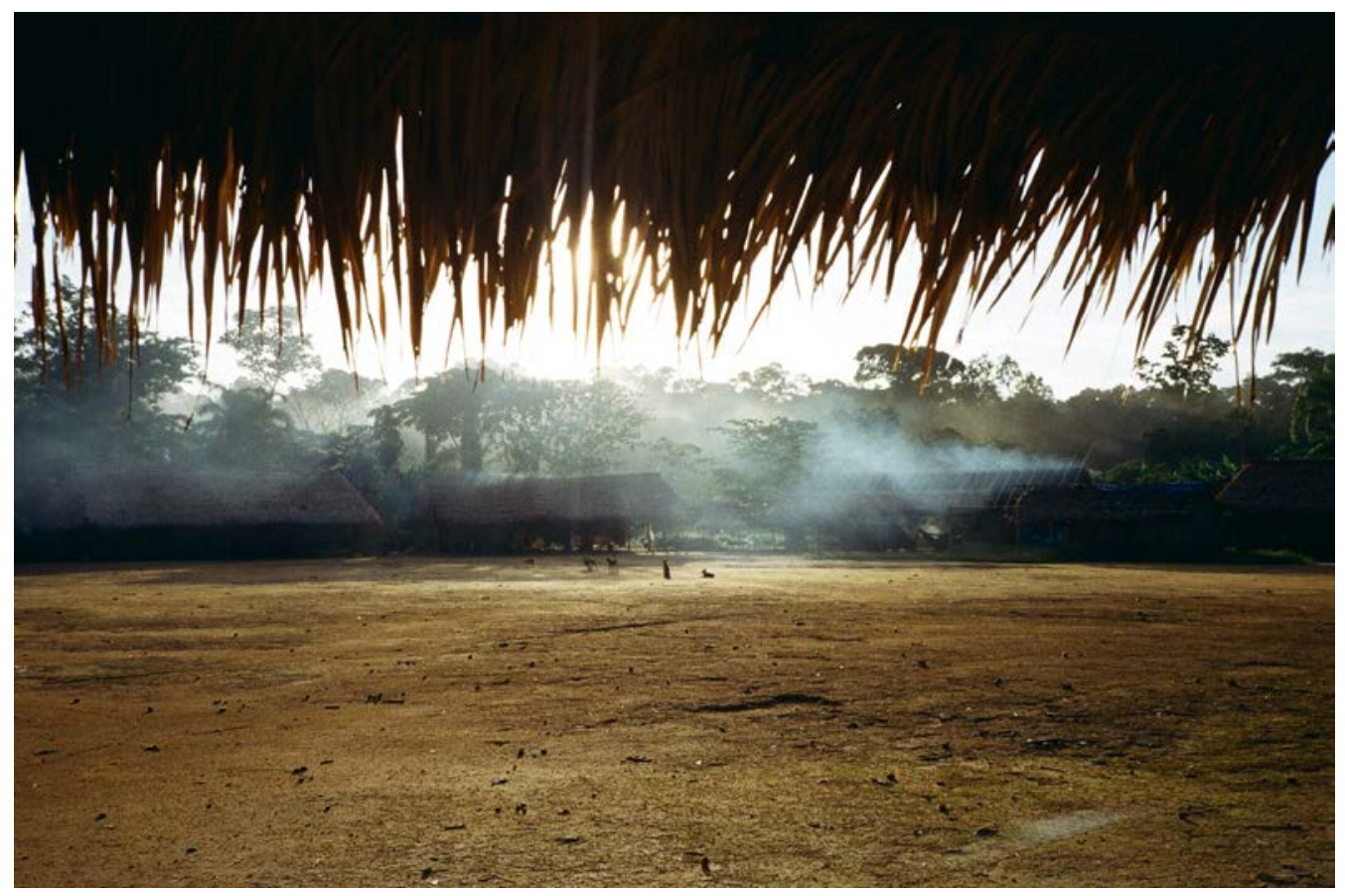

Fig. 58. Ao amanhecer, com os primeiros raios de sol, a umidade da cobertura de palha das casas evapora e faz uma densa bruma sobre o xapono. O registro é da soleira (hato nahi heha) da casa de Francisco, que nos hospeda no Pukima Cachoeira. O "hotel", como ele brinca (2019). 
"Agir como um falcão-caburé" não deve aqui ser entendido como uma simples forma de identificação, como uma correspondência de relações, e tampouco como mera semelhança, uma imitação ou uma reprodução plena. Ao contrário, seguindo a lógica do devir de Gilles Deleuze e Felix Guattari (2012), "agir como" talvez seja melhor compreendido como uma modulação - processo no qual a partir da variação de dois pontos implica numa mudança, em um terceiro ponto distinto do primeiro e do segundo, como uma mistura cromática. Nesse sentido, "agir como um falcão-caburé" implica numa modulação de afecções associadas à loquacidade da fala do falcão, mas também ao domínio dos cantos, o traquejo com a voz dos outros (as outras línguas) e a capacidade de liderar (cf. Albert, 2016).

Tal operação se assemelha àquelas agenciadas por diferentes espécies de pássaros em diversas sociocosmologias indígenas, com destaque ao japim (ayakorã, Cacicus cela), considerado entre os Ashaninka do Alto Juruá, assim como entre os Yanomami, por exemplo, como um poderoso xamã (Carneiro da Cunha, 1998, p. 15). Os japins são pássaros que partilham do apreço pela vida coletiva - e vivem em ninhos-malocas de palha de palmeiras, em forma de bolsa penduradas nos galhos, em grandes comunidades aéreas-arbóreas. Em especial, os japins apresentam uma excepcional capacidade de "imitar" (no sentido da modulação acima descrito) os cantos, os chamados e os ruídos que escutam de diversas outras espécies animais, razão pela qual são frequentemente considerados como um pássaro poliglota ou, como ouvi certa vez de um interlocutor do xapono Pukima Beira, um "pássaro gravador".

Além do mais, não deixar de ressaltar aos ouvidos a aparente relação entre a vocalização do gavião-azul (Buteogallus schistaceusi), associado ao antepassado mítico Koparisini que vimos acima, e a retórica Yanomami evidenciada pelo kãwãamou. Refiro-me ao modo pelo qual as exortações proferidas pelos patapata pë são realizadas, do ponto de vista estilístico, digamos, de modo semelhante à frequência do canto dessa ave. Em algumas falas, cujos temas pontuamos acima, e ao fim das sentenças, as palavras costumam ser finalizadas com um estribilho, sem função semântica, possivelmente transcritas como auuueee, de modo que o $a$ é entoado com uma breve exclamação em crescendo (isto é, com aumento da intensidade sonora) e segue com prolongado diminuendo (numa redução progressiva da intensidade sonora) no uuueee. O recurso é utilizado também em outros contextos, como na chegada de convidados 

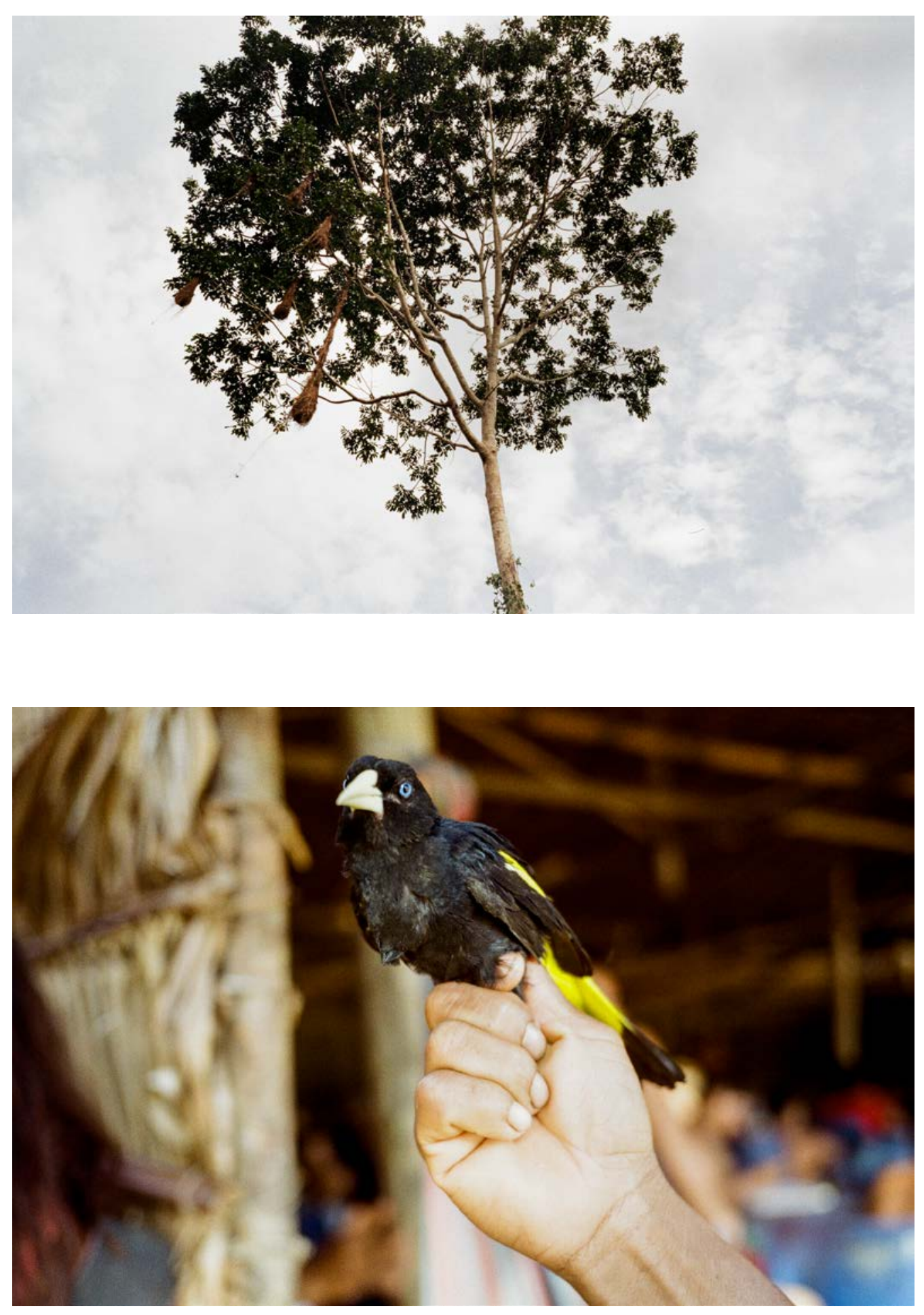

Fig. 59/60. Acima, ninhos de japim (ayakorã, Cacicus cela) pendurados em uma árvore alta da floresta, na beira do Alto Rio Marauiá. Abaixo, japim, o "pássaro gravador", domesticado no xapono Pukima Beira (2019). 
a uma festa funerária, e normalmente direcionado ao xapono como um todo, como no caso do kãwãamou. Ao que parece, auuueee transmite um efeito ainda maior de encorajamento, estímulo e incitação, que é algo que se espera das exortações do kãwãamou, diferente de meras ordens ou comandos, como é comum na política ameríndia "que parece rechaçar, de maneira sistemática, o uso da voz autoritária” (Cesarino, 2020, p. 06).

A correspondência ou o "agir como" (-mou), nesse caso, indica mais um "mimetismo ontológico" do que um "mimetismo sonoro", adaptando o argumento de Bruce Albert (2016, p. 96). Albert, em "A floresta poliglota [La fôret polyglotte]", expõe essa formulação para pensar o modo pelo qual os pajés "se identificam" com a imagem de Ayakorãriwë, o Japim, serimagem dos tempos primeiros e de importância singular no xamanismo yanomami e amazônico de modo geral. A identificação, portanto, permite que os pajés façam dançar e descer essas imagens dos ancestrais animais na forma de espíritos auxiliares. Ao mesmo tempo, o pajé adota as suas potências associadas à sua imagem essencial, as suas subjetividades e suas expressões vocais (Albert, 2016, p. 96) e, no caso de Ayakorãriwë, ao menos entre os pajés Yanomam, trata-se do "único espírito que permite aos xamãs regurgitar à vista de todos as plantas de feitiçaria e os objetos malignos que eles extraem do corpo dos doentes" (Albert, 2016, p. 96). No caso do kãwãamou, as correspondências entre a vocalização do gaviãoazul e do falcão caburé com as falas dos patapata pë poderiam ser também entendidas como um possível modo de identificação, um "mimetismo ontológico". O modo de identificação, nesse caso, parte do pressuposto de que diferentes seres possuem diferentes línguas - como estes concebem suas vocalizações para si mesmos (cf. Albert, 2016) - e, de forma análoga à diplomacia xamânica, esse modo de comunicação sugere "uma estética política comum que atravessa fronteiras ontológicas" (Luciani 2017, p. 210).

Como no mito de origem da noite ou conforme os hábitos do falcãocaburé, o mais comum é que as exortações do kãwãamou sejam feitas na hora do orvalho, bem no início da manhã. As falas começam na penumbra da noite, antes da alvorada. Durante seu desenrolar, que acompanha o amanhecer do dia, uma verdadeira névoa de orvalho evapora dos tetos de palha aquecidos pelas fogueiras domésticas e pelo sol nascente, envolvendo o xapono numa densa bruma. Em outros momentos o kãwãamou pode ser feito também após o anoitecer, quando as famílias estão reunidas nas casas, em volta das fogueiras e descansando nas redes. As vozes são 
emitidas num volume apenas um pouco mais alto do que o regular, e gritos ou exclamações em voz alta se fazem presentes apenas quando a gravidade do assunto extrapola o controle preciso da fala de chefe. Em ambos os períodos, a fala ora mistura-se ao sonho daqueles que ainda não despertaram e ora confunde-se com diálogos no íntimo descanso noturno e, discretamente, passeia pelo xapono, involuntariamente adentrando as moradas, os ouvidos e os pensamentos de todas e todos. Como diz Kopenawa: "Os grandes homens arengam as pessoas de suas casas durante a noite e elas, mesmo que permaneçam em silêncio e pareçam estar dormindo, escutam com atenção. Ao nascer do dia, seu espírito desperta e dizem a si mesmas: 'Haixopë! Aquelas eram boas palavras! Vamos responder seguindo os seus conselhos!"' (2015, p. 381).

O tom de voz, portanto, é modulado seguindo a escala do xapono. Ao mesmo tempo, poderíamos pensar que talvez seja o kãwãamou, na verdade, que define a escala ideal do xapono, isto é, aquela em que o som, sem grandes esforços, navega pelo terreiro central e adentra o conjunto de todas moradas. No kãwãamou a fala é emitida a partir das soleiras das casas ou, em outros momentos, desde o meio do xapono. Em ambos os horários em que a fala é feita, dificilmente a pessoa que fala, de pé, está completamente visível, seja pela escuridão da noite ou seja pela delicada luz nascente da alvorada. Para além da não-visibilidade do emissor, a fala circula e serpenteia pelo espaço e o xapono adquire também uma dimensão acústica, evidenciando a disposição circular da casa-aldeia e da clareira em que se situa. A clareira do xapono é exígua, rodeada e restrita pelas árvores da floresta, e o som das falas do kãwãamou reverbera no interior dos limites do terreiro, de forma que "o meio do xapono" (xapono heha) transforma-se numa espécie de amplificador, intensificando as falas mas também todos os "ruídos [noises] que constituem a vida Yanomami em comum" (Carrera Rubio, 2004, p. 121)".

É essa polifonia amplificada pela floresta, destacada aqui às falas do kãwãamou, que representa um papel central na construção da sociabilidade yanomami, conforme propõe Carrera Rubio. Segundo o autor, são as palavras e os sons que circulam pelo xapono que transmitem um senso de "proximidade [togetherness]", avivando e eliciando as relações estabelecidas dentro do grupo local através dessa polifonia e (a partir de Alan Passes) dos "ruídos da coexistência [loudness of coexisting]" (Carreira Rubio, 2004, p. 123). Assim como faz Alejandro 
Reig (2016, p. 213), ampliando essa proposição de Carrera Rubio para pensar também os aspectos sensoriais e corporais na construção desse espaço de sociabilidade, sugiro uma leitura adicional à ideia dos "ruídos da coexistência" também como forma de constituição da espacialidade do xapono. Nesse sentido, ressalto a possibilidade de pensarmos a produção do xapono a partir das modulações sonoras e das dimensões políticas e acústicas da fala, especialmente, a fala do kãwãamou.

Diferente dos diálogos cerimoniais Yanomami, o kãwãamou é especialmente orientado para dentro, ou seja, é dirigido aos exclusivamente co-residentes do xapono, articulando temas que pertencem ao dia-a-dia daqueles que se põem a viver juntos. O contraste entre a "linguagem de dentro" do kãwãamou e a "linguagem para fora" (Carrera Rubio, 2004) é dado em comparação aos diálogos cerimoniais conhecidos por himou e wayamou. Estes têm sua origem associada também ao mito de origem da noite (cf. Carrera Rubio, 2004) e assim conta Kopenawa: "Foi Titiri, o espírito da noite, que no primeiro tempo ensinou o uso do wayamuu e do yãimuu [mq. wayamou e himou]. Fez isso para que pudéssemos fazer entender uns aos outros nossos pensamentos, evitando assim que brigássemos sem medida. [...] Então, Titiri disse a nossos ancestrais: 'Que essa fala da noite fique no fundo de seu pensamento! Graças a ela, vocês serão realmente ouvidos por aqueles que vierem visitá-los"” (Kopenawa; Albert, 2015, p. 378). Neste trabalho não detalharei a prática destas formas de diálogo "para fora" (himou e wayamou), mas apenas a introduzo aqui como forma de contraste ao diálogo kãwãamou ("de dentro"), para evidenciar o sentido deste, mais do que discorrer sobre os outros. Como sintetiza José A. Kelly Luciani, enquanto o kãwãamou articula um conteúdo moralizante, direcionado internamente para a criação de uma disposição coletiva e que "procura evitar a degradação da convivialidade em briga, conflito e divisão, os diálogos wayamou [feitos de noite e considerando o himou como uma variante diurna deste] podem ser vistos como dispositivo para converter relações de troca suspeitas em outras mutualmente proveitosas, ou pelo menos para apaziguar o status mútuo de comunidades social e geograficamente distantes" (2015, p. 47).

Os diálogos "para fora", então, costumam ser realizados na ocasião de visitas, sejam visitas orientadas para troca ou no âmbito de festas funerárias reahu ou em assembleias e encontros políticos entre associações yanomami (como forma atual e atualizada dessa forma de 
diálogo), e são orientados para estabelecer relações de troca e resolução de conflitos. Nestes diálogos, hóspede e anfitrião se põem frente a frente, de cócoras e movimentando-se sobre as pernas agachadas, trocando toques e falas metafóricas e ritmadas sobre lugares habitados no passado, eventos míticos, registros de relações mútuas, previsões e intenções de trocas, conflitos e alianças possíveis (cf. Lizot, 1994; Alès, 2003; Luciani, 2015, 2017). Em suma, se os diálogos "para fora" são formas eventuais e cerimoniais de troca (troca de palavras e premissa para troca de coisas; cf. Lizot, 1994) e de manutenção das relações entre grupos aliados, o kãwãamou volta-se para "dentro", tanto na forma quanto nos temas, e é o que "faz as pessoas [do xapono] sentirem que não estão sozinhas; como um importante componente diário das práticas de convivialidade, essa arte verbal comunica o sentimento de pertencer a uma comunidade (Alès, 2000, p. 138). E, assim, faz o xapono: expressão espacial do viver junto, construídos pelas práticas de convivialidade, regidas e mantidas pela palavra.

A ideia sintética de "viver junto" - que em Yanomami se diz yaiprou (verbo intransitivo com sentido de "dispor-se a viver junto"; Lizot, 2004, p. 490) - vai de encontro com a perspectiva de Peter Rivière (1984) sobre a organização social dos povos das Guianas. Não me detenho na sua argumentação a partir do conceito de settlement, traduzível por "comunidade", "povoação" ou "ocupação" e que o permitiu elaborar um estudo comparativo entre os diferentes grupos da região das Guianas, cada qual com diferentes formas de constituir-se espacialmente. Há diferenças substanciais entre as ditas comunidades e o xapono, objeto central dessa reflexão e que extrapola a análise comparativa do autor. Uma dela, à guisa de exemplo, diz respeito à relação dos grupos com seus chefes, sendo este compreendido como "fundador" ou "dono" (Rivière, 1984, p. 72) das comunidades - no sentido de grupos locais organizados numa mesma casa comunal ou numa mesma aldeia -, noções essas que, ao que me parece, não são compartilhadas com os vizinhos Yanomami. No entanto, interessanos aqui a perspectiva analítica de Rivière, em que mais do que pensar o settlement (ou o xapono, no nosso caso) do ponto de vista geográfico ou de sua constituição física e formal, podemos pensá-lo como "um conjunto de pessoas vivendo juntas no mesmo lugar" (Rivière, 1984, p. 72).

Esse "viver junto" (yaiprou), contudo, pressupõe certa instabilidade - própria de uma dinâmica socioespacial de sucessivas agregações e 
desagregações, mudanças e fissões, contatos e conflitos - e que deve ser controlada, justamente, pela palavra. "Viver junto" é assim uma condição provisória e que deve ser mantida, no caso, pelo intermédio da fala do kãwãamou como forma de manutenção das relações de convivialidade no xapono. Philippe Descola, tratando dos diálogos cerimoniais do povo Achuar da Amazônia equatoriana e peruana, indica algo análogo: "Estar junto, para os Achuar, é antes de tudo estar junto com alguns, contra alguns outros, numa coagulação efêmera do vínculo social" (Descola, 2006, p. 433). E Cesarino, comentando esse trecho, destaca a provisoriedade da aglutinação desse coletivo possível que se dá, sugestivamente, de modo distinto do "mito da universalidade do coletivo, precisamente o mito da democracia" (2020, p. 14).

A provisoriedade de "viver junto", então, oscila entre o reunir-se (kõkãmou) e o separar-se (xetekou) através dos fluxos de relação que se fazem, desfazem e refazem no tempo e no espaço. Esse fluxo pode ser visto de maneira condensada, por exemplo, no processo cíclico de mudança e construção de um novo xapono após a fissão de uma parcela do grupo local por um conflito familiar: a separação que leva à dispersão para em seguida renovar o ciclo através de uma reunião que leva à concentração e assim por diante. É nesse sentido então que momentos de mais estabilidade pressupõe momentos de mais instabilidade; e vice e versa. De modo que, antes de um genérico coletivismo primitivo ou universal, trata-se na verdade de um "mundo perenemente dividido por forças de agregação e desagregação" - assim como o mundo Kanamari da Amazônia Ocidental analisado por Luiz Costa (2007, p. 210).

Como sugere Rivière, a casa (ou o xapono, em nosso caso) pode ser pensada como "uma comunidade estável, desde que apenas por um momento, no que de outra forma é um mundo de arranjos sociais fluídos" (1995, p. 199). Caso contrário, se a instabilidade se mantém e os conflitos se agravam, o grupo pode vir a dividir-se e o xapono, abandonado, sujeito à consumação orgânica pela floresta ou pelo fogo. É também nesse sentido, demonstrado aqui simetricamente ao revés, que penso que é a fala que faz o xapono, dado que nessa condição efêmera a palavra dos líderes ou dos velhos - especialistas do jeito de viver - é essencial para a manutenção do sentido e da condição de viver junto (yaiprou). Assim, se uma "liderança bem-sucedida deriva de uma habilidade de manejar as redes sociais que constituem a povoação [settlement] e a comunidade" (Rivière, 1984, p. 72), 
é também através da fala que se constitui o espaço do xapono, moldado à escala e à potência da palavra. Dessa forma, assim como são as narrativas antigas que informam o jeito de viver e que sustentam "o jeito de pendurar redes", penso que é a palavra em si, serpenteando pela clareira habitada, que dá ao xapono seu sentido essencial, sua sempre efêmera coesão social e espacial, da forma circular à escala medida pela voz.

Como ensina a história de Koparisini, morar é reunir-se pelo diálogo, através do qual as relações são mantidas, ordenadas e, literalmente, circuladas. No kãwãamou, contudo, o diálogo se estabelece na escala do xapono e os interlocutores, que podem ser múltiplos, eventualmente replicam as falas dos locutores principais. A fala do kãwãamou, assim, é apenas aparentemente monológica. Isso, pois, além de eventuais, distantes e fragmentárias back channel responses - expressões padronizadas, como exclamações de concordância, que transmitem a atenção da audiência e dos interlocutores ao que é dito pelo locutor -, podem também partir de distintos pontos dos círculos de casas do xapono respostas sobre o assunto em questão, reações a acusações ou contestações do que está sendo dito ou exortado, multiplicando as vozes do ato dialógico no espaço da clareira. Nesses casos, a soleira das casas ou o meio do xapono abremse para outros falantes que, um por vez, se intercalam no kãwãamou estendido. Tanto na chave do diálogo quanto das exortações feitas pelo përiomí cotidianamente, o kãwãamou configura-se como uma estratégia de resolução de conflitos e um meio de aliviar a tensões internas ao grupo local, organizando a vida e as relações no xapono, permitindo-o, ao fim, que ele se mantenha junto. Como observa Jacques Lizot, "velhos e líderes são diplomatas: sem nenhum poder de coerção, eles esforçam-se para convencer pela palavra e pelo exemplo. Sua autoridade é moral" (1994, p. 216). Eles são, pois, "os postes da casa". Dessa maneira, é através da palavra que o xapono, no sentido do grupo de pessoas vivendo juntas, é conduzido para o devido "caminho do comportamento moral [path of moral behavior]" (Luciani, 2011, p. 119) ou, melhor dizendo, ao "nosso jeito de ser" (yama ki rë kuaaiwei).

Essa forma de diálogo ecoa uma formulação conhecida de Pierre Clastres. Tratando da fala de chefe entre os Guarani, Clastres se pergunta: "Do que fala, com efeito, o chefe nos discursos cotidianos que a tribo espera? Ele expressa a tradição. Ele expressa aquilo que faz o 'nós' no qual uma sociedade particular se reconhece" (1990, p. 367). A ideia, 
literalmente, reverbera entre os Yanomami. Adriano, përiomí do xapono Pukima Cachoeira, sobre esse ponto, certa vez me disse: "A informação que eu pego, eu tenho que distribuir [...] quando eu estou aqui fica tudo certo, quando eu saio daqui dá problema". A função do përiomí, ou do chefe, portanto, é colocar a informação (em sentido amplo) para circular (literalmente, inclusive) e orientar o correto "jeito de ser", pontuado pelas ações e tarefas do cotidiano. Dentre as informações circuladas para esse fim, reside como pano de fundo a "tradição" ou, como sugere Cesarino referindo-se originalmente aos diálogos tsãiki dos Marubo), as "referências a um passado prototípico" (2020, p. 20). Segundo o autor: "Sem a garantia desse pano de fundo, a sociedade tenderia a se esgarçar e a se dispersar em uma miríade de parcialidades desconectadas" (Cesarino, 2020, p. 20). Nesse mesmo sentido é que, através do kãwãamou, o përiomí conduz o xapono e o respectivo grupo local para um ponto comum de proximidade e bem-estar, aglutinando "parcialidades potencialmente dispersas entre si, tal como um corpo aglutina duplos ou componentes da pessoa" (Cesarino, 2020, p. 20, nota 10). Sem isso, como alerta Adriano, "dá problema" - no limite, operando a passagem da concentração à dispersão.

É através desse pano de fundo prototípico, então, que na ausência da "abstração do comum" os diálogos tal como o kãwãamou ou o tsãiki marubo são capazes de "garantir a integridade das redes sociais a partir de sua própria fluidez molecular, de sua conectividade pelas relações de vizinhança, de sua instabilidade constitutiva" e, enfim, "garantir a continuidade dos vínculos entre grupos locais" (Cesarino, 2020, p. 20). Como destaca Carrera Rubio, o kãwãamou "contribui para a criação, por meio da linguagem, de um verdadeiro senso de comunidade" (2004, p. 57). Assim, é através da linguagem, da fala e da palavra, enunciada com sabedoria pelos "postes da casa" (patapata pë), que a comunidade e o xapono se constituem e se mantém, enquanto grupo, mas, também, enquanto espaço, construído e moldado, continuamente, em função do viver junto (yaiprou). Em suma, o que o kãwãamou faz é "afirmar aquilo que faz o ser mesmo da sociedade" (Clastres, H., 2016, p. 368): viver junto (yaiprou), o nosso jeito de viver; no xapono, na terra-floresta, como sempre vivemos.

Viver só, ao contrário, é a negação da sociabilidade e da humanidade; pressupõe o silêncio e, com isso, a ausência dos ruídos da coexistência que fazem, mas também animam a vida no xapono. Esse contraste pode 
ser evidenciado através da narrativa mítica sobre Pore (ou Poreawë e Porehimi, como dizem em outras regiões), "espírito fantasma" dos tempos primeiros e "dono" das primeiras bananas cultivadas. O mito poderia ter resumido da seguinte maneira (e vale notar que em diversas versões ele e o mito de origem da noite de Titiri compõem uma só narrativa; cf. Wilbert; Simoneau, 1990): "Foi o Fantasma [Pore] que fez aparecer as bananeiras. Elas vêm do Fantasma. Por que ele as fez aparecer? Porque ele tinha um filho, que ele tinha de alimentar. Ao ouvir a voz do filho do Fantasma, Horonami [o "primeiro dono da floresta", como vimos] descobriu a sua moradia e pegou com ele umas mudas de bananeiras. $\mathrm{O}$ Fantasma não tinha outros parentes. [...] Quando não existia nem roças, nem Yanomami, depois de Horonami pegar as bananeiras, ao chegar ao seu xapono, ele deu nomes a elas, deixando com isso o ensinamento de como plantar as bananeiras. Ele as pegou para nós as termos" (Ballester, 2017b, p. 62-63).

Pore, em todas variações do mito, encarna a anti-sociabilidade de diversas maneiras. Como na versão apresentada acima, diz-se que Pore "não tinha outros parentes", mas apenas um filho, o que decerto constitui um xapono fora do comum. Em outra versão, registrada por Lizot, a história começa assim: "Seu nome era Pore [Revenant, no original] e ele morava sozinho, para lá, naquela direção" (Wilbert; Simoneau, 1990, p. 155, M71). E noutra, também registrada por Lizot, Horonami relata o seu feito aos seus parentes, indo à busca da morada e da roça de Pore: "[...] Eu me perdi na região Yakërë, em uma terra distante onde nenhum Yanomami vive. Eu roubei algumas bananeiras em uma roça" (Wilbert; Simoneau, 1990, p. 152, M69). Seu isolamento, "onde nenhum Yanomami vive", vai de encontro com a imagem de alguém que mora só e, como aponta Carrera Rubio, em outros mitos que apresentam a figura de Pore, também se ressalta o fato de que ele não tinha fogo e nenhuma fumaça era vista saindo de sua casa, de modo que sua morada era terrivelmente fria e a comida que oferecia aos seus visitantes era inadequada, crua talvez (2004, p. 110, nota 43).

Em todos os casos, o que o retrato de Pore revela é uma oposição radical ao devido "caminho do comportamento moral [path of moral behavior]" (Luciani, 2011, p. 119). A antinomia torna-se nítida pelo xapono de Pore, sem fogo e só. Em suma, um estranho xapono onde vivese só, e não junto; um anti-xapono, decerto. O modo de habitar de Pore 
constitui-se assim numa negação da humanidade. Habitar numa terra onde "nenhum Yanomami vive" é o oposto daquilo que todo mundo é. Como indica o sufixo -teri - posposto aos nomes pessoais vinculados ao xapono que pertence, como em Adriano Pukimapiwëteri - alguém só pode ser coabitante de um xapono, vinculado a uma rede de outros xapono (yahiterimi), numa região específica, com nome e com gente junta, sejam aliados ou inimigos, em algum canto da terra-floresta urihi. Morar só, por outro lado, é morar em silêncio. Não por acaso, um dos aspectos mais ressaltados de Pore é a sua estranha fala, sua voz medonha e, essencialmente, o fato de que ele não fala direito. Pore ainda é retratado como sovina e, não fosse o roubo de Horonami, as bananas não existiriam: "Nossos antepassados e os antepassados dos napë não comeram banana desde o início. Hoje, tanto os napë quanto os Yanomami plantam bananas, a partir do ensinamento de Horonami" (Ballester, 2017b, p. 63).

A relação entre não falar corretamente e a sovinice de Pore é determinante. Como indica Lizot (1994), os Yanomami estabelecem uma equivalência entre a troca de palavras e a troca de bens, como vimos no caso do wayamou. Nos diálogos cerimoniais, assim como em contextos mais gerais, a habilidade de falar bem é referida como aka hayu; e o seu oposto, referindo àqueles que não falam corretamente, como aka porepi, que significa, literalmente, "ter a língua de fantasma". Aka hayu, no entanto, refere-se também a habilidade e a participação ativa nas trocas, e indica aquele que sabe "fazer um pedido ou uma exigência como é devido" (Lizot, 2004, p. 8). Aka porepí, por outro lado, indica os mudos, os estrangeiros que não falam a língua yanomamí, quem não sabe proceder nas trocas e "dá objetos sem receber nada em troca", quem não participa corretamente do wayamou e, de forma extremada, quem é "incapaz de participar de diálogos cerimoniais" (Lizot, 2004, p. 8). Pore, epítome daqueles que falam como "fantasma", contraria assim a moral propriamente humana e os ideais do viver junto (yaiprou). Como resume Carreira Rubio: "Esse é um tipo de vida particular que, para os Yanomami, é sintetizado por uma vida de comunidade; é uma vida social dependente de uma socialidade adequada, uma que leva para uma boa convivialidade; é uma vida que tem que ser constantemente socializada e, portanto, criada e mantida dialogicamente através de meios apropriados de comunicação" (2004, p. 317).

O anti-xapono de Pore aponta ainda para outro desdobramento 


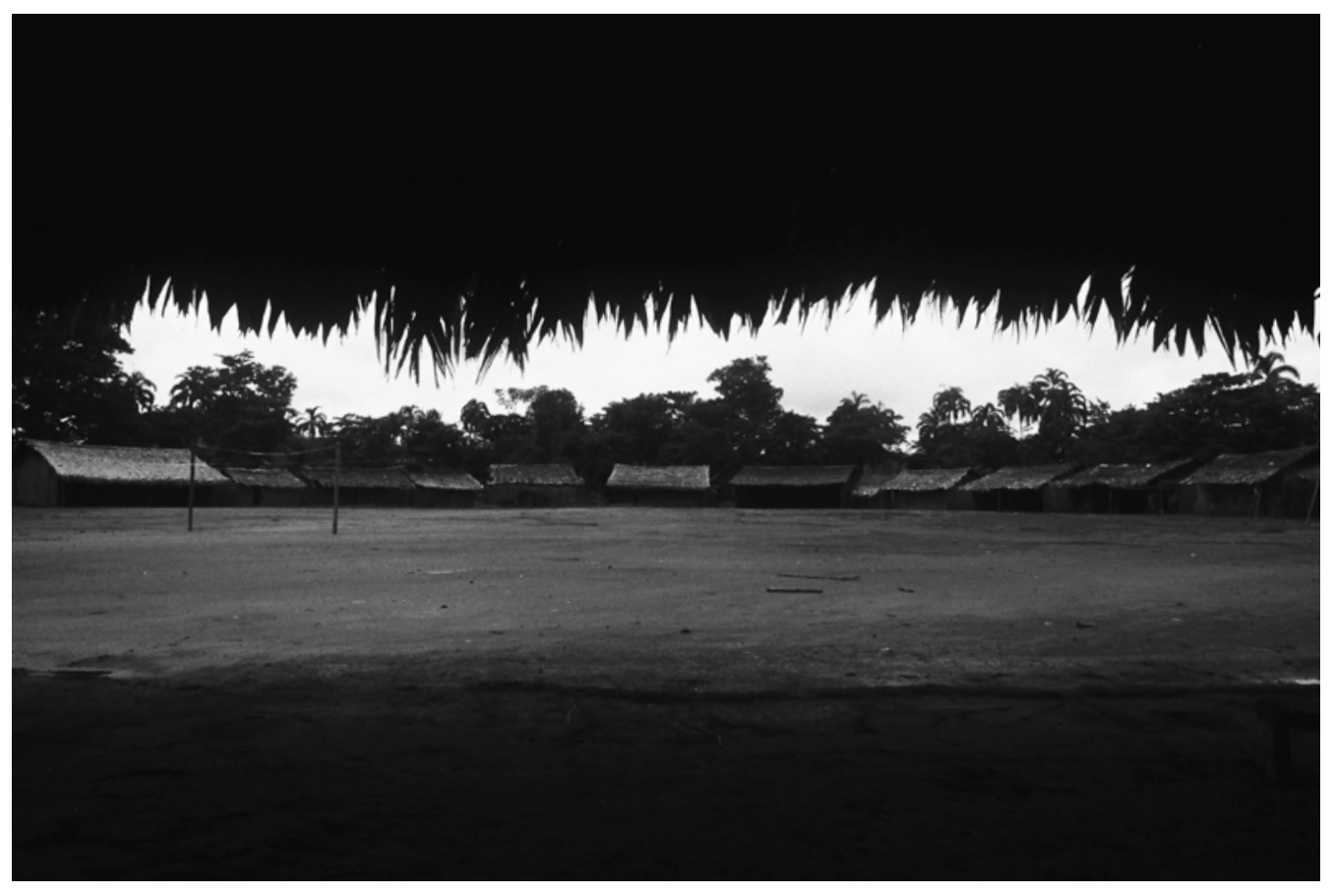

Fig. 61. Antigo xapono Pukima Beira vazio, em 2016, após a mudança das famílias para uma nova clareira rio acima, visto desde a soleira (hato nahi heha) de uma casa (fotografia de Daniel Jabra). 
extremo à forma ideal de sociabilidade yanomami. Vazio e silencioso, o xapono é associado à falta das condições que possibilitariam a vida comunitária e, por extensão, à ausência de vida - a morte. A associação com a morte é também feita com a própria figura de Pore, dado que é conhecido por ser o "dono" das bananas, fruta que é diretamente associada aos procedimentos funerários da festa reahu e, como na versão da narrativa registrada por Luis Cocco, teria sido Pore que ensinou os Yanomami cremar, triturar e tomar as cinzas dos ossos com mingau de banana, como é costume entre diversos grupos yanomami, sendo assim associado ao ensinamento de como fazer o reahu (Wilbert; Simoneau, 1990, p. 162, M74). Essa relação entre Pore, sua casa vazia e a morte extrapola as narrativas míticas e ecoa também em situações oníricas e cotidianas e, como aponta Carreira Rubio, torna-se de diferentes maneiras um "sinônimo de morte" (2004, p. 120). É o que veremos a seguir.

Certa feita, conversando sobre sonhos com o përiomí do Pukima Cachoeira, ele deu um exemplo interessante dessa associação, e contou que no "tempo do sonho" sonhar com uma casa em chamas, com toda a estrutura e todos os pertences pegando fogo, pode ser um indicativo de que algum parente próximo está em perigo e pode vir a morrer, de modo que os pajés devem imediatamente ser comunicados para rastrear a fonte do perigo e, à sua maneira, controlá-lo. De forma complementar, um excerto do relato de Helena Valero, situado no momento em que um grupo familiar que habitava o xapono de frente à sua morada se mudou, deixando vazia aquela parte da casa-aldeia, também exemplifica bem essa associação: "É melhor também irmos embora; aquela parte do xapono que está na minha frente foi esvaziada. Quando é assim, a doença aparece, pore chega, os hekura inimigos vêm e levam as crianças" (Biocca, 1996, p. 75).

Pore, mencionado por Helena Valero, não se refere ao antepassado mítico Pore (Poreawë, Porehimi), mas aos espectros potencialmente perigosos que vagueiam pela floresta e pelas clareiras habitadas. Estes correspondem ao pei no uhutipi - a "imagem" ou "componente imaterial" - das pessoas que, ao morrer, se transforma em pore. De forma complementar, segundo a escatologia yanomami, outro componente imaterial da pessoa se transforma após a morte. Trata-se do pei mí ãmo, que significa literalmente "o centro" (em oposição ao invólucro corporal pei siki) e indica o "princípio vital" da pessoa que, ao morrer, transformase em no porepí, a "alma" ou o "duplo" da pessoa que migra para o xapono 
celeste dos mortos, como veremos adiante. Os espectros pore podem protagonizar aparições agressivas onde quebram com os joelhos e a espinha dorsal dos humanos, capturam o pei mi ãmo ou capturam a boca das pessoas, deformando-a e debilitando seus órgãos vocais (Lizot, 2004, p. 320).

São nos lugares que deixaram de ser habitados, como menciona Helena Valero, que os espectros pore, além de outras ameaças, podem se manifestar. No entanto, para além de "sinônimo" (Carreira Rubio, 2004, p. 120), a morte é, não raro, a própria razão para mudança de um grupo familiar ou do grupo local como um todo, abandonando o xapono, deixando-lhe vazio ou em chamas. Colocar fogo em todas as casas é uma estratégia de lidar com os espectros e seres-imagem perigosos, assim como as indesejadas memórias da ou das pessoas que ali faleceram e também com rastros de epidemias xawara que, por exemplo, pode ter levado muitos à morte naquele determinado local (como malária, tuberculose ou sarampo, associadas ao contato com os napë).

Assim como nos procedimentos funerários yanomami, onde os corpos são cremados em uma grande fogueira no centro do xapono e os ossos reservados para as festas funerárias reahu, atear fogo nas casas afasta os espectros pore e seres-imagem hekura perigosos, associados aos rastros dos mortos que ali habitavam em diferentes momentos do tempo. Essa prática varia de caso a caso e, no caso de uma morte isolada, nem sempre a casa da pessoa e da família é queimada, diferente de todos seus pertences de uso pessoal e do seu próprio corpo. No Marauiá, especificamente, costuma-se também atear fogo em todo o xapono, após a mudança de um determinado grupo e o abandono da antiga aldeia. Como conta o përiomi Adriano Pukimapiwëtëri, quando o grupo do Pukima Cachoeira, que habitava rio acima até 2014, se mudou para o atual xapono, todas as casas foram queimadas como forma de afugentar os pore que vagavam por ali, mas também as memórias dos falecidos, dado que muitos morreram (por causas diversas, ao que me parece) naquela localidade.

Durante a época de colheita da pupunha, sobretudo, são frequentes as idas ao antigo xapono para colher os frutos e o përiomí, especificamente, ainda mantém na região do sopé da serra grandes roças de banana. Ao atravessar o meio do antigo xapono, na vasta clareira de cerca de cem metros de diâmetro, não se vê praticamente nenhum rastro das antigas moradas e, aos poucos, a capoeira cresce no antigo terreiro e a floresta avança pelas bordas. A preocupação atual, no entanto, é de que a ampla 
clareira possa vir a ser usada como pista de pouso de helicópteros de garimpeiros ilegais. Como forma de afugentar possíveis invasores, mas não apenas, o përiomí e o povo do xapono pensam em construir novas casas, mais ligeiras e menos duráveis, e transformar o antigo xapono num "xapono secundário" (porakapi xapono). Essa prática de ter dois xapono é algo tradicional entre os Yanomami, como conta Adriano. Nessa segunda morada, poderiam abrir novas roças e voltar a morar na região do sopé da serra, mas dessa vez temporariamente, durante certos períodos do ano.

Noutra ocasião, logo após acompanharmos o processo de mudança do grupo do Pukima Beira para um novo xapono rio acima, em 2016, voltamos ao xapono recém-abandonado, junto de três jovens, para buscar medicamentos e equipamentos do posto de saúde que foi também deixado para trás. Adentrar o seu terreiro central, observando a um só tempo todas as casas esvaziadas era, de certa forma, como se adentrássemos uma aldeia fantasma. O xapono estava completamente vazio e silencioso. Uma condição inimaginável se comparada com um xapono cheio de vida e cheio de gente. Lá, de fato, não era mais um xapono. Não à toa, os Yanomami que estavam conosco foram para lá de objetivos. Foram até o posto, pegaram tudo o que era necessário, deram uma olhada de longe, e voltaram ao barco.

Eram muitas as razões enunciadas naquele momento sobre a mudança rio acima entre os moradores do Pukima Beira. As explicações abordavam o baixo desempenho das roças e da distância cada vez maior para localizar áreas férteis e abrir novas clareiras, dado que estavam naquele local desde a década de 1990, mas também a quantidade de mosquitos ou a falta de espaço no xapono para casas de novas e jovens famílias. Entretanto, todos compartilhavam do argumento de que, com o tempo prolongado habitando aquele mesmo local, foram muitos os que ali morreram, de modo que o xapono era permeado de memórias dos entes falecidos e, com isso, da constante ameaça de indesejados encontros com espectros pore. Assim, nota-se que além do xapono vazio ser "sinônimo de morte", como aponta Carrera Rubio (2004, p. 120), é também a morte a própria razão para que o xapono se esvazie, através da fissão de um ou alguns grupos familiares - como foi o caso do grupo do atual Pukima Cachoeira que deixou essa mesma localidade do antigo Pukima Beira por conta da epidemia de malária e das mortes dela decorrentes - ou da mudança do grupo local como um todo - como fez o grupo do Pukima Beira 
em 2016. Como diz Carrera Rubio, "falar de casas é falar das pessoas que vivem nelas" (2004, p. 122), de modo que, uma vez invertida a proposição do vínculo entre as casas e as pessoas (vivas, no caso), complexifica-se e também se reforça as associações entre as casas vazias e o tema da morte.

Foi na noite de uma festa funerária reahu que o përiomí Adriano Pukimapiwëtëri me contou, com muita preocupação, sobre como os Yanomami da região de Maturacá (os ditos Kohoroxitari) estavam lidando com os corpos dos mortos. Estávamos hospedados na casa do përíomi do xapono Raita, em que se situava a festa, e Adriano reforçava o valor e a importância das festas reahu para os Yanomami, dizendo que "por pouco o que aconteceu no Maturacá também não aconteceu aqui no Marauiá". Ele se referia ao fato de que "no Maturacá já não fazem mais reahu" (com exceção, em alguns casos, quando o morto é um velho), devido à forte presença dos missionários salesianos que, se não proibiram, desvirtuaram moralmente a prática e estimularam o sepultamento dos corpos em vez da cremação e do consumo das cinzas dos ossos. E, opondo-se aos ditos Kohoroxitari, assim dizia: "Tá vendo como nossa tradição está forte e viva?". Adriano contava-me que na última vez que esteve lá (por conta de uma assembleia, ao que parece, dado que evitam visitar a região com medo de ataques vingativos dos pajés de lá), ficou consternado com as sepulturas atrás das casas dos mortos que lá habitavam. Preocupado, dizia-me o quão perigoso era aquilo, uma vez que o pore dos mortos jamais deixaria os vivos em paz, perturbando a vida, o bem-estar e a estabilidade do grupo.

Como dizia Adriano, os próprios Yanomami (que também se autodenominam por Yanonami) contam que nas serras do Pico da Neblina, chamado de yaripo, "há vários fantasmas de Yanonami que morreram e não puderam ser cremados, assim como de garimpeiros que foram assassinados, sendo muito comum ouvi-los à noite vagando e emitindo sons de lamento e, frequentemente, demonstrando agressividade" (Menezes, 2010, p. 92). Contam os Yanomami do Marauiá que logo que "o coração e a respiração para, a pessoa [ou o no porepi, o "duplo" da pessoa] sobe pelo caminho" que a levará até o xapono dos mortos. No entanto, para que o caminho seja efetivamente trilhado, desviando definitivamente os desejos nostálgicos do no porepi de retornar junto aos seus, é necessário que seus ossos e suas cinzas recebam um tratamento ritual e funerário apropriado. Como nota Albert (1985, p. 639), essa passagem do xapono daqui para o 


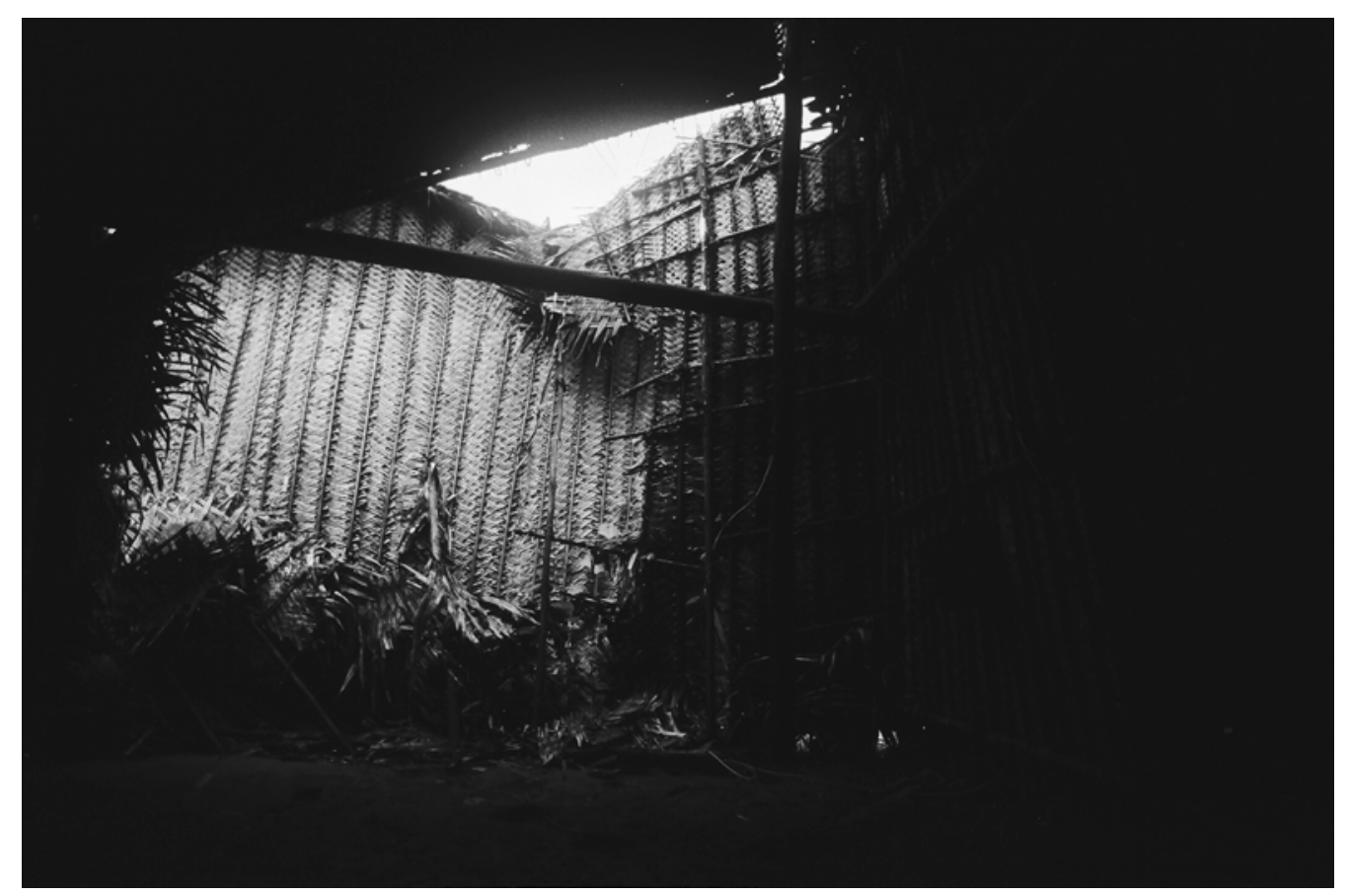

Fig. 62. Casa vazia e abandonada, já antiga e deteriorada pelo tempo, no antigo xapono Pukima Beira, registrada após a mudança das famílias, em 2016 (fotografia de Daniel Jabra). 


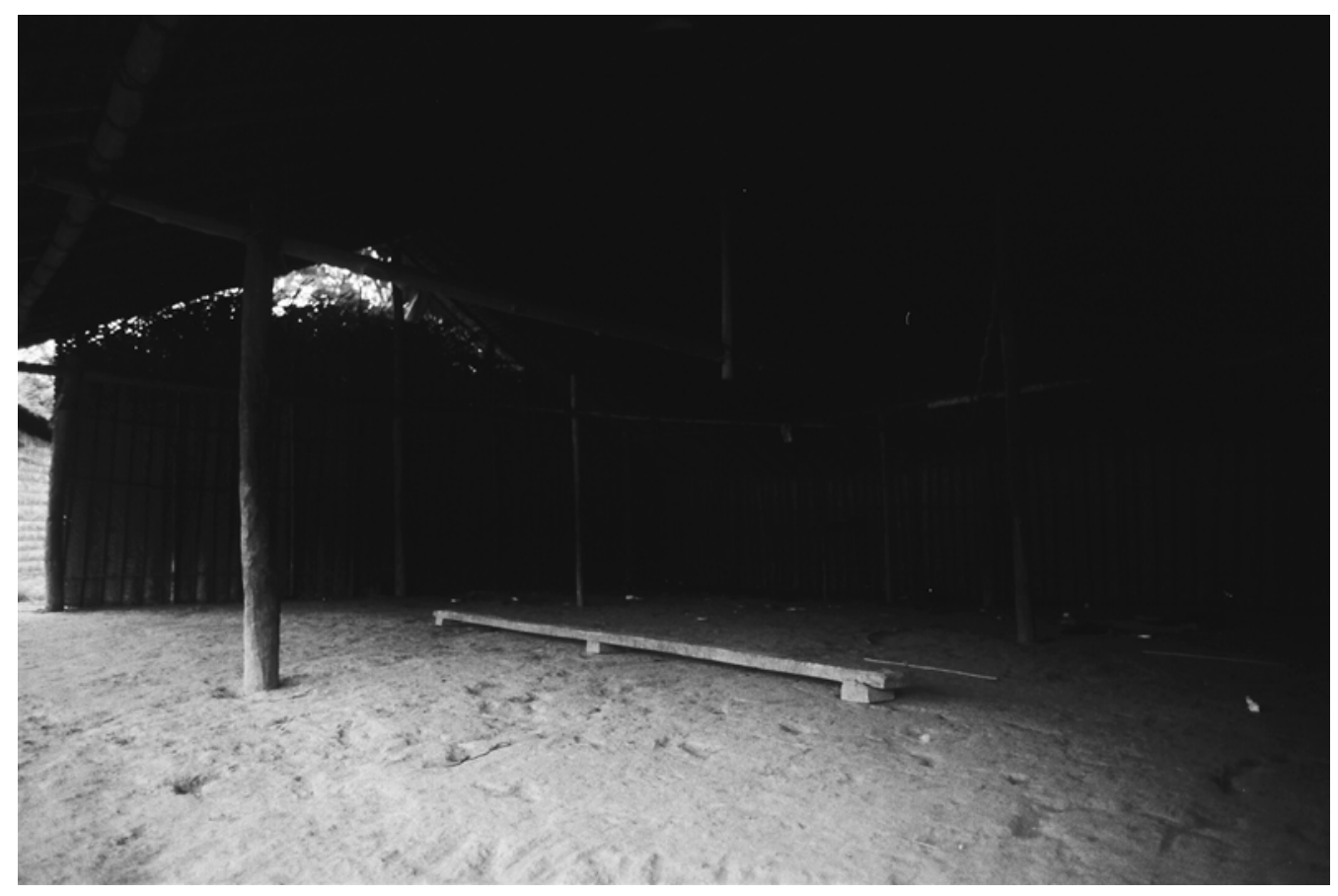

Fig. 63. Banco (rotikëotima) utilizado pelos pajés (hekura). Vazio, silêncio. Casa abandonada após a mudança das famílias do antigo xapono Pukima Beira, em 2016 (fotografia de Daniel Jabra). 
de lá não é absolutamente definitiva e durante todo o período do luto e do reahu, ou seja, até que todas as cinzas dos ossos dos mortos tenham sido ingeridas ou enterradas (como costumam fazer outros grupos yanomami, diferente dos Yanomami do Marauiá), a pessoa em sua forma espectral continua a se manifestar movida pela nostalgia. Nostalgia esta que, tal como sugere Cesarino em Oniska (2011), constitui-se como um traço da ausência e da distância decorrente das cisões entre duplos e corpos e que, se não for devidamente manejada, nesse caso, através do reahu, tais traços (vestígios ou rastros) da pessoa acabam por gerar uma conjunção dolorosa e perigosa entre vivos e mortos. Como também nota Albert, é "o retorno indesejável do espectro do morto a partir dos 'vestígios' [unokë] de sua existência terrestre que alimenta sem cessar a nostalgia dolorosa a ele vinculada" (1985, p. 394).

No caso do Maturacá, onde os procedimentos não estavam sendo seguidos apropriadamente, como ressalta Adriano, este perigo é latente, constante e aparentemente irresolúvel. Os ossos são considerados como componentes parimi do corpo, pois são os elementos mais resistentes e duráveis, e assim, são associados à permanência, à indestrutibilidade e ao eterno. Uma vez enterrados, os ossos demoram anos para se desintegrarem completamente e o espectro da pessoa pode colocar as comunidades num período de extrema fragilidade e perigo, onde abre-se para uma potencial confusão escatológica entre os vivos e os espectros dos mortos. Essa confusão refere-se ao fato de que, se os mortos não seguem efetivamente seus caminhos, passa haver uma junção, ou uma falta de distinção, entre dois mundos que deveriam essencialmente permanecer separados. Maria Inês Smiljanic, comentando a mesma situação de arrefecimento das práticas funerárias na região do Maturacá, diz o seguinte: "O mundo retraiu-se a ponto de tornar-se um cosmos condensado onde todas as categorias de seres competem por ocuparem o mesmo espaço, o que suscita forte reação por parte dos Yanomami, pois a presença dos mortos entre os vivos é prenúncio do fim da sociedade" (2002, p. 152).

$O$ retorno dos mortos ao espaço do xapono tem um eco direto nas narrativas míticas yanomami. Segundo uma versão registrada por Lizot entre os Yanomami, a situação ocorria constantemente durante os tempos primeiros até que, por conta do voo repentino e espalhafatoso de um grande e mítico inhambu-açu (Tinamus major), os espectros no porepí voltaram definitivamente à aldeia dos mortos (Wilbert; Simoneau, 1990, 
p. 86-88, M36). Em outra versão, registrada por Albert entre os Yanomam, o retorno dos mortos ao xapono celeste se deu pelo canto do inhambuaçu, que estava guardado num cesto no interior de uma morada e cujo chamado é emitido regularmente no crepúsculo, anunciando o anoitecer, operando no mito como um elemento de conexão entre noite e dia, vida e morte (Wilbert; Simoneau, 1990, p.327, nota 187). Nessa versão, entretanto, o rompimento definitivo da conexão entre céu (mortos) e terra (vivos) decorreu da ação do ancestral do papagaio-moleiro (Amazona farinosa), que cortou o cipó mítico, situado nas cabeceiras de um igarapé na montanha, por onde os mortos refaziam os caminhos de volta do céu à terra (Wilbert; Simoneau, 1990, p. 84-86, M35).

Em ambas narrativas os espectros insistem em retornar ao xapono de seus familiares e a performarem, para o assombro dos vivos, suas atividades cotidianas, questionando a queima de suas moradas e de seus pertences e, inclusive, se perguntando sobre seus próprios ossos reservados nos cestos, nublando, de fato, a separação entre mundos. Os familiares vivos, no entanto, esquivam-se em contar a verdade aos mortos. Na versão registrada por Lizot, por exemplo, a narrativa termina da seguinte maneira: "A mãe manteve a filha [o "duplo" da filha] sentada perto dela na beira da rede, abraçando-a. Mas quando de repente chegou o silêncio, ela apertou os braços em vão; apenas madeira carbonizada permaneceu em suas mãos. No exato momento em que o grande inhambu-açu voou, o papagaio respondeu a uma das perguntas da mulher morta, dizendo: 'Esses são seus ossos queimados"' (Wilbert; Simoneau, 1990, p. 88, M36). Nota-se, portanto, que a pergunta feita ao papagaio, que até então apenas observava a cena empoleirado e quieto, indiretamente indica que teria respondido a uma pergunta semelhante à feita pela criança que desaparece dos braços da mãe: "Mãe, o que tem dentro do cesto?", ao passo que a mãe, desajeitada, responde, "É um condimento que estou guardando" (Wilbert; Simoneau, 1990, p. 88, M36). A simultaneidade do retorno definitivo dos mortos, assustados pelo voo do inhambu-açu, e a constatação do duplo da mulher sobre seus próprios ossos queimados reforça o sentido das práticas e dos cuidados com os ossos dos mortos, destinados a assegurar a correta passagem ao xapono celeste e a manter a devida separação entre os dois mundos. E é notável, entretanto, o que resta nos braços da mãe: madeira carbonizada, como uma marca, digamos, da perecibilidade da vida e dos corpos humanos que, diferente dos ossos - componentes parimi (duráveis, 
imperecíveis) do corpo - queimam como madeira.

Os eventos narrados pelos mitos se assemelham, de certa maneira, a uma conhecida história contada pelos Pukimapiwëteri do Alto Marauiá. Numa das vezes que a escutamos, Cláudio, pajé do Pukima Cachoeira e irmão de Adriano, contou que um jovem pajé do Manakapiwëi (grupo Momohiteri que recém migrou para o lado brasileiro da fronteira) certa feita estave muito doente e faleceu. Na verdade, os parentes julgaram que ele estava morto, mas passaram a estranhar: "Dizem que ele voltava". Com o estranhamento, seu corpo foi posto num cesto e "ele parecia não querer morrer". Durante algum tempo o jovem oscilava entre a vida e a morte e, como contam, foi "resgatado" por um pajé, "até que voltou". "Dizem que lá", no xapono dos mortos, "ele viu tudo" e, de modo inusitado, voltou para contar a história. De volta à vida, ele contou que ao chegar lá foi conduzido por um parente até sua nova morada. O relato, inclusive, dialoga com a descrição feita certa vez por Hipólito, o përiomi do Pukima Beira, contando que ao subir pelo caminho dos mortos, já no meio do caminho os parentes (também falecidos) do morto vêm buscálo, e juntos atravessam diametralmente o meio do grande xapono dos mortos, conduzindo-o diretamente para sua casa, de modo a evitar conflitos com os outros parentes mortos do recém-chegado. O jovem pajé do Manakapiwëi, no entanto, diz que ao chegar lá não foi aceito pelo përiomi do xapono celeste, pois ele não estava totalmente morto e "não se poderia misturar as coisas; daí, voltou", conforme nos relatou o pajé do Pukima Cachoeira.

O desfecho e o retorno à terra dos vivos, logo, inverte a relação entre vivos e mortos. Se num momento os mortos são tratados de modo a garantir a clara distinção ontológica com os vivos, através dos procedimentos funerários adequados, nessa história o que se nota é um movimento contrário, da parte dos mortos, mas também em torno da manutenção da alteridade definitiva entre mortos e vivos, pois "não se poderia misturar as coisas". A inversão escatológica, todavia, também se manifesta de outras maneiras. Isso, pois, o xapono dos mortos é visto como contendo uma sociabilidade e também uma espacialidade semelhante à dos humanos, exceto que tudo é dotado de uma "qualidade superlativa" (Albert, 1985, p. 639). A alteridade radical com os mortos, assim, implica numa inversão da vida na terra somente no que diz respeito à sua qualidade essencial, dado que os meios pelo qual as coisas se efetuam são 
potencialmente análogos. Como contou-me o përiomi̇ do Pukima Beira, para lá vão todos, a não ser aqueles que foram muito sovinas enquanto vivos; estes, indesejados mesmo entre os mortos, que não o aceitariam entre eles, vão "para outro lugar, para lá do céu, onde só tem fogo". Disse que assim que a pessoa passa a não respirar direito ou quando se agrava o quadro da doença, "os parentes de lá [os espectros dos mortos, no porepi] já começam a fazer a comida e a preparar a casa para sua recepção". Lá, contou-me, "eles abrem roça, tem floresta, e tudo mais", e o xapono dos mortos "é como o daqui, de palha, mas é grande, grande mesmo". Outros interlocutores do Pukima Beira reafirmavam a dimensão superlativa do xapono dos mortos. Situado "atrás do céu", como relatam, há apenas um xapono para todos Yanomami, de todas as gerações, e por isso sua escala espectral grandiosa, de modo que cada família tem a sua própria casa dentro do grande círculo habitado, como uma replicação simétrica, embora aumentada e condensada, das moradas na terra. As casas, por sua vez, são como as daqui, mas assim como os frutos da floresta e os cultivos das roças celestes, "não acabam nunca".

Esse xapono único, simétrico e superlativo dos mortos diferencia-se radicalmente do xapono vazio e silencioso de Pore, associado ele próprio à morte. No entanto, a associação da morada de Pore se torna mais nítida com o perigo, com a eminência ou a própria memória da morte e dos falecidos, como vimos acima, e inverte-se completamente ao se tratar do próprio xapono celeste dos mortos. Lá, de forma singular, simétrica mas elevada à potência máxima, vão todos (ou quase todos) e todos moram juntos, de modo que o princípio da sociabilidade do xapono, o "viver junto" (yaiprou) é extremado. Em outras palavras, se o xapono de Pore é justo a negação da humanidade e, por isso, um anti-xapono, o xapono dos mortos é seu oposto, uma hipérbole da humanidade, mas em sua forma espectral no porepi e parimi, isto é, eterna e sem fim. A hipérbole do viver junto, portanto, acompanha a própria potência de conflitos familiares, lembrando do que conta o përiomí do Pukima Beira, que ao passo que o recém-falecido chega na metade do caminho para o xapono celeste seus parentes vêm logo busca-lo, conduzindo diretamente à sua morada e, assim, evitando conflitos que poderiam se dar de imediato, bastando sua presença (espectral) perante os olhares raivosos dos demais parentes, afins e potenciais inimigos.

A relação entre o tamanho do xapono e a potencial instabilidade 
da relação, com a proliferação dos conflitos familiares, não se restringe apenas ao superlativo xapono celeste mas replica-se, diminuída, também em sua versão terrestre. Inclusive, o aumento populacional do grupo local - resultante de um largo momento de estabilidade social, política e espacial, que pode inclusive estar vinculado à maior sedentarizarão decorrente do contato - é equivalente ao aumento dos conflitos familiares e, portanto, da instabilidade do viver junto. Paradoxalmente, o que se nota é o movimento cíclico de estabilidade, crescimento, instabilidade, fissão e, novamente, estabilidade - como demonstrado pelos movimentos que conformaram os atuais (e em contínua transformação) arranjos socioespaciais do Rio Marauiá. A situação tende ainda a se tornar ainda mais aguda quando, acompanhando o crescimento de grupo familiares bilaterais, novas lideranças emergem e disputam o espaço da palavra e da organização do grupo com o përiomí considerado o principal. Na configuração política do xapono é comum haver mais de um përiomí e, como notamos acima, costuma haver (de forma esquemática) um përiomi para cada facção familiar (ou grupo familiar estendido) e, portanto, com o crescimento dos grupos familiares estes tomam um lugar de proeminência até que, uma vez que os desacordos atinjam seus limites, resulte na fissão dos grupos e seus respectivos chefes, e junto deles, de um possível abandono do xapono.

Como nota Rivière falando dos povos das Guianas mas em consonância com o caso dos Yanomami: "Quanto mais bem sucedido for o líder, mais populosa sua comunidade será, mas paradoxalmente no seu sucesso [success] jazem as sementes do seu próprio fracasso [failure]" (1995, p. 200-201). Destituída de seu caráter moralizante, que não me parece ser o caso entre os Yanomami, a síntese de Rivière resume bem as formas parciais de mediação e gestão da coesão do grupo local do xapono e, em outras palavras, o regime de autoridade não-autoritária dos përiomí yanomami. Essa propriedade dos lideres, evidentemente, não é exclusividade dos përiomi yanomami, como há tempos demonstrou Clastres (2003), mas acredito que adiciona uma camada a mais no sentido do "viver junto" (yaiprou), explicitando os conflitos inerentes e complementando o que observamos anteriormente sobre a sua forma intrinsecamente instável, cuja estabilidade é sempre parcial e momentânea.

É também o que observa Catherine Alès sobre os Yanomami, que diz que: "Quanto maior é a casa, maior a quantidade de líderes que pode 
haver" (2003, p. 201). O aparente paradoxo reside no fato de que se o përiomí é capaz de manter a coesão e o bem-estar do grupo de forma exemplar, por exemplo, através da manutenção da prática do kãwãamou e, com isso, com a contínua orientação dos rumos e gestão dos conflitos no interior do grupo, ao invés de isso aumentar seu poder ou autoridade, pelo contrário, este é colocado em cheque, já que aumentam também os líderes e, enfim, as vozes que circulam pelo xapono, potencialmente discordantes, provocativas e combativas.

Apesar das vozes dissonantes serpenteando pelo xapono, os limites dos conflitos se dão com o fim do diálogo e com a escassez da fala, ou seja, quando esta já não é mais o suficiente e a comunicação, enfim, cessa. Na escala das relações pessoais e cotidianas, é também o silêncio daqueles que repousam na rede, com o olhar fixo e a boca calada, o maior indicador de raiva e chateação. Colocado em diálogo com os sentidos do silêncio do anti-xapono de Pore, o que se destaca é o silêncio como forma de anti-sociabilidade por excelência, algo que no caso do mito nega a humanidade e também a possibilidade de constituição de uma comunidade, comunidade essa que só pode existir enquanto uma comunidade de vozes. No caso de um conflito generalizado no interior do grupo local, por sua vez, e seguido do ponto em que o diálogo perde a eficácia, resta a alternativa da troca de agressões ou, ainda pior, a fissão de um ou mais grupos familiares, rompendo por completo a estabilidade de determinada comunidade, cindindo-a e fragmentando-a, junto de suas formas atuais de afinidade e aliança.

Os përiomí, fundamentalmente, trabalham para que isso não ocorra e como conta Alès, os Yanomami com os quais trabalhou costumam designar os líderes justamente como os que atingiram um "pufi wakakawë", isto é, um espírito ou um pensamento lúcido e transparente. Não necessariamente os përiomí precisam ser velhos ou anciões e, assim como em outras partes do território yanomami, no Marauiá houve (e ainda há) uma tendência após o contato com os napë de rejuvenescimento dos përiomí, passando dos patapata pë aos mais jovens que também partilham dum "pensamento lúcido" e, sobretudo, possuem um domínio adicional da palavra, pois falam português e têm melhores condições de negociar e se comunicar os napë. Como no caso do Pukima Cachoeira, Adriano foi estimulado a frequentar a escola e a aprender a língua portuguesa pelo seu pai, Cândido, um dos antigos përiomi entre os Pukimapiwëteri. Assim 
que atingiu uma fala lúcida e propriamente "forte", como costuma dizer, sucedeu seu pai e passou a representar a liderança do xapono, dentro e, em outros contextos, também fora dele. No entanto, é ainda fundamental a posição dos mais velhos, "os que mantêm a casa forte [nano rofote rë huëpouwehei]", como registrado por Alès (2003, p. 203). Manter a casa forte corresponde a manter o grupo (ou a comunidade) forte, no sentido da permanência e da estabilidade. Logo, a associação com os patapata pë ("os postes da casa", "os que mantêm a casa forte") é feita pois são estes que a habitam a mais tempo, ou seja, são como as raízes do grupo e da casa e, portanto, são estes que, através da palavra e das exortações públicas mantém a estabilidade do xapono. Como relata Alès: "Os Yanomami dizem que em uma casa são eles [os patapata pë] que 'protegem', 'defendem', 'preservam' a sua urifi [m.q. urihi, "terra-floresta"], o habitat, incluindo, nesse sentido, tanto o território quanto os seus habitantes" (2003, p. 203).

São nos discursos kãwãamou, portanto, onde essa função conservadora do "espaço da chefia" (Clastres, 2003, p. 219), no sentido de manter a unidade do grupo, adquire seu caráter essencial, exercida tão somente pela palavra. Ao mesmo tempo em que há um "processo permanente de cisão" - enquanto "técnica" por excelência da recusa das sociedades indígenas em "ser grande", como diz Clastres (2003, p. 251) - há também um desejo de manutenção da unidade e da estabilidade do grupo local, ao menos até o ponto em que o conflito é controlável. Nesse sentido, como sugere também Clastres, o discurso dos përiomi, assim como dos patapata pë, é um discurso "conservador" e "contra a mudança" (2003, p. 255), o que é nítido no kãwãamou, que faz amplo uso do argumento essencialmente "conservador" referindo-se aos modos pelos quais os antepassados faziam e viviam, trabalhando e vivendo da forma correta e verdadeira, juntos e em paz. É o que diz Alès, referindose à razão de ser dos longos, e por vezes exaltados, monólogos no kãwãamou: "Se os velhos nutrem um sonho, é o de viver tranquilamente e em paz (não importa o quão impossível isso possa parecer). Eles querem explicitamente permanecer na mesma área o maior tempo possível, uma intenção expressa pela afirmação 'viver (no mesmo lugar) pacificamente' [to live quietly, na tradução original], përïaï onowë" (Alès, 2000, p. 139). É essa, afinal, a condição de ser humano: viver junto e pendurar redes, fazendo parentes e fazendo o xapono, dialogando e também brigando, se juntando e se dividindo, morrendo e fazendo festa. 


\section{Casa-montanha}

Frente a las ruinas imperiales el cacique lyëwei-teri manifestó:

-¿No ves? Estas son las casas que antiguamente hizo Omawë.

Luis Cocco (1972, p. 474)

As pupunheiras, com seus grandes cachos de frutos, são amplamente cultivadas nas roças em torno dos xapono. Caminhando pelo mato identifica-se uma antiga clareira habitada pelo círculo de pupunheiras, como uma espécie de marcador espacial ("spatial marker", cf. Reig, 2013, p. 172), que indica a permanência de um grupo e a presença de um antigo xapono num local onde a construção em si pode, inclusive, ter desaparecido integralmente, queimada ou consumida pela floresta. $\mathrm{O}$ cultivo da pupunha é antigo na Amazônia e, segundo o biólogo Charles Clement (1988), estima-se que essa espécie de palmeira começou a ser domesticada há dez mil anos, tanto pelos frutos quanto pela sua madeira; ademais, todas as partes da planta podem ser aproveitadas, da raiz às folhas. Durante o "tempo da pupunha" (raxa tehë) entre dezembro e fevereiro aproximadamente, na época de seca, os frutos são muito apreciados e constituem uma das mais importantes fontes da alimentação dos Yanomami. A planta se desenvolve rapidamente e seguirá por aproximadamente vinte anos produzindo frutos, de modo que, pela sua agilidade, se adequa bem à dinâmica de mudança dos xapono e, mesmo que a roça tenha sido abandonada, são constantes os deslocamentos às antigas clareiras para coletar os grandes cachos de raxa, mantendo ativas as visitas aos antigos xapono e expandindo ainda mais a rede de caminhos e clareiras percorridos por cada grupo local.

Segundo Jean-Pierre Chaumeil, como a pupunheira faz com que os grupos retornem periodicamente às antigas roças para sua farta coleta, a palmeira é associada por diversos povos amazônicos à memória dos mortos, aos espíritos e aos ancestrais (1987, p. 101). Entre os Yanomami as pupunheiras promovem o mesmo tipo de movimentação, mas não são associadas diretamente a nenhum vínculo ancestral e o círculo de 
pupunheiras ao redor de uma aldeia abandonada costuma inclusive perdurar mais do que as próprias casas, já que estas costumam ser queimadas quando o xapono é abandonado, justamente para apagar as memórias dos locais anteriormente habitados e normalmente associados aos parentes que ali faleceram no decorrer dos anos. Essa memória indesejada, que pode trazer dor e sofrimento aos aparentados, deve então ser destruída. As casas, deliberadamente, desaparecem. E ficam os círculos de pupunhas assim como ficam os círculos de paricá.

O paricá (Anadenanthera peregrina) ou pararo, como se diz em Yanomami, é cultivado ao redor das casas e suas sementes são a base do preparo do epena, substância inalada pelos pajés. Em português a espécie é mais conhecida como angico, e paricá é como os Yanomami as chamam no Marauiá. É bem conhecida nos países hispano-americanos como yopo, sendo utilizada por diferentes povos indígenas sul-americanos. Os pés de paricá costumam conformar um segundo círculo em volta do círculo de casas do xapono e normalmente não podem ser cortados, inclusive criando empecilhos para a eventual expansão de uma aldeia, impedindo que esta cresça seu diâmetro. Não são em todas regiões do território yanomami que o pararo é cultivado; no Marauiá, os xapono são conhecidos por terem uma abundância de paricá, sendo um local em que a espécie desenvolve bem. Acumuladas e guardadas em sacos ou potes, estas são reservadas acima do fogo doméstico, secando e defumando por longos períodos. As sementes de pararo, como contam os pajés, são a coisa mais valiosa dentre as trocas intercomunitárias e visitas mútuas costumam ocorrer com o intuito de obter ou trocar tais sementes, por exemplo com o povo do Marari, ávidos por conseguir alguns sacos das sementes secas para o preparo do epena.

Mais do que recursos essenciais aos pajés, na perspectiva dos espíritos auxiliares hekura, as sementes de paricá (pararo) são vistas como frutos de pupunha (raxa), "comida de espírito" (hekura pani) como dizem os pajés, e as árvores pararo hi são vistas como "casa de espíritos" (hekura pë yahipi) especialmente associada à Ihamariwë (Bradypus tridactylus), o ser-imagem Preguiça que apresentou a espécie e o preparo de suas sementes aos antigos. Assim, estes não só conformam o espaço da aldeia, como também constituem um segundo círculo de casas, casas de espíritos. Esse segundo círculo, como me disse um interlocutor do Pukima Beira, Sérgio Pukimapiwëteri, indica que ali naquele xapono tem "muitos pajés 

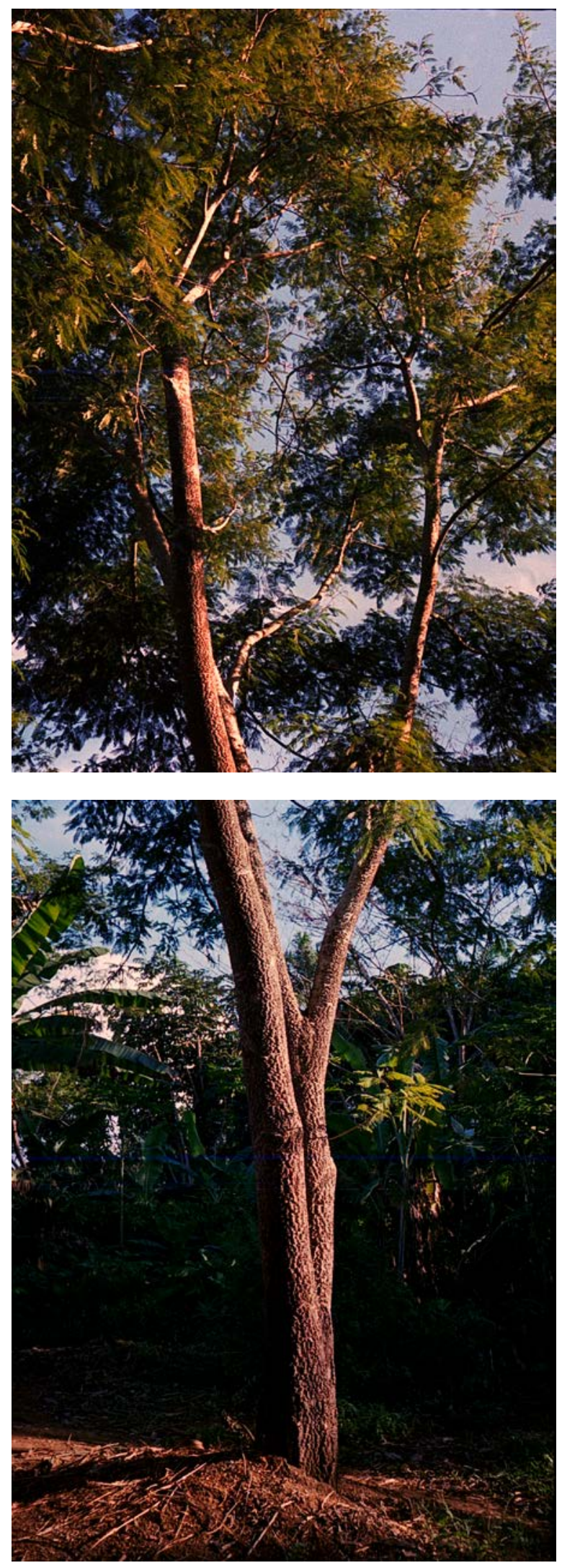

Fig. 64/65. Pé de paricá (pararo,

Anadenanthera peregrina) aos fundos da casa de Francisco no Pukima Cachoeira (2020). 
hekura, pajés fortes, muitas casas de espírito". Não se trata, entretanto, de um simbolismo ou um sentido metafórico associado às pupunhas ou ao paricá, mas de duas referências, no sentido de dois referentes possíveis, que bifurcam o enunciado em função da perspectiva. Assim, multiplicam e replicam o sentido do xapono através de uma variação posicional e escalar. E assim contou Sérgio: "Aquilo que vemos como paricá os hekura veem como pupunha. São as roças dos hekura".

Em numa longa caminhada à roça de bananas de Adriano, cravada no plano inclinado de uma serra, o përiomi do Pukima Cachoeira contoume sobre o ser-imagem Japim, dono das primeiras pupunhas, genro do ancestral Veado (Hayariwë; da família Cervidae):

Antigamente, Hayariwë morava em um xapono como o nosso. Um dia, mandou o seu genro Ayakorãriwë [Japim], buscar pupunhas para si. Mas o que o Hayariwë chamava de pupunhas [raxa, Bactris gasipaes], na verdade, eram frutos de paxiúba [Socratea exorrhiza]. Ayakorãriwë, inconformado, foi atrás de buscar pupunhas de verdade, comida de verdade, para seu sogro, junto de sua esposa. Voltaram ao xapono de Hayariwë com muitos cachos e com os cestos cheios de pupunha, mas ao entrarem na casa e mostrarem a Hayariwë, este ficou com muita raiva. Desceu da rede, cheirou paricá, e de tanta raiva começou a puxar a carne e os músculos da sua perna para cima, para a coxa. Sua esposa e sua filha fizeram o mesmo, puxavam toda a carne, e também fizeram o mesmo nos braços. Se transformaram em veados e fugiram para o mato.

Com o equívoco, nota-se que a paxiúba, vista por Hayariwë como pupunha, não é cultivada, mas coletada e cortada no mato, sobretudo, para produzir ripas para os telhados das casas ou arcos. Ambas as palmeiras são da mesma família Arecaceae e compartilham de uma característica comum, sua madeira dura e resistente. A paxiúba, no entanto, é associada ao universo da floresta e a pupunha, ao contrário, assim como o paricá, está associada ao espaço doméstico do xapono e das roças (hikari të ka). Em outra versão do mesmo mito de Hayariwë coletado por Lizot, os japins (ayakorã) possuem rabos amarelos (Cacicus cela) ou vermelhos (Cacicus haemorrhous) assim como as duas variantes dos frutos de pupunha cultivadas (Lizot et al., 1993, p. 36). Na versão coletada por Luis Cocco adiciona-se ainda que assim que Hayariwë fugiu, correndo para o mato já convertido em veado, isto é, em animal, "se converteu em um rochedo 
que tem a cor da pele do veado [...] de onde vêm agora os hekura que nós invocamos" (Lizot et al., 1993, p. 206).

Ayakorãriwë, o Japim, é também associado à conquista do fogo, em algumas versões desses mitos de origem, roubado de dentro da boca do Jacaré, Iwariwë. Com o fogo, também relacionado ao universo doméstico, veio também uma espécie de maldição pela mulher de Iwariwë:

Vocês pegaram o fogo, então vocês chorarão quando cremarem os seus mortos, vocês sofrerão e chorarão pelos seus mortos cremados [...] Eu vou ao igarapé e ficarei feliz lá com meu marido para sempre [...] Vocês sofrerão com o fogo. Ele se tornará eterno. O fogo derreterá seus olhos! (Ballester, 2017a, p. 66).

Sob o fogo, portanto, veio a sina: "É verdade o que ela disse, a esposa disse a verdade. Nós nos cremamos, nossa carne queima, ela falou certo. Se isso não houvesse acontecido não nos cremaríamos" (Ballester, 2017a, p. 66-67). Outra versão da narrativa, coletada por Cocco, registra também que quando o autor do roubo chegou ao xapono, distribuindo o fogo a todos os Yanomami, de tanta animação deu um salto tão alto que acabou colocando fogo nas árvores da mata. É por isso, conforme o mito, que, além dos corpos, a madeira queima (Lizot et al., 1993, p. 208). Nessa mesma variação do mito, o recado foi similar:

Esse fogo que vocês tanto queriam [...] vai fazê-los sofrer. Deviam ter deixado tranquilo na boca de seu dono e haveriam sido felizes. Mas vocês roubaram algo parimi que os fará sofrer para sempre: todos vocês e todos os descendentes de vocês se queimarão com o fogo. Eu não quero ser queimada. Eu vou viver feliz sem fogo. Nunca o fogo tocará o meu corpo (Lizot et al., 1993, p. 208).

Parimi indica aquilo que é eterno, imortal e também aquilo que não tem fim. Nesse sentido, parimi é associado à imortalidade dos hekura, os seres-imagem dos tempos primeiros cuja existência nunca cessa, mas, pelo contrário, se multiplica sem fim. No entanto, parimi pode também se referir a algo considerado como essencial e fundamental à conformação do universo yanomami. Ou, num sentido derivado desse, como algo que dispensa preocupação quanto à manutenção de sua existência, isto é, aquilo que permanece, que perdura e que continua sem fim, como o fogo, as casas (ou "o jeito de pendurar redes") e os hekura, por exemplo (Lizot, 2004, p. 296).

Se a vida no xapono é animada pela aquisição da pupunha, o que permite não só seu cultivo para alimentação mas também a realização 
da festa funerária reahu, onde são enchidos grandes cestos de pupunha durante o "tempo da pupunha" (raxa tëhë) distribuídos aos convidados no fim da festa, o contraponto colocado pelos mitos é um fado incontornável: como a madeira, os corpos queimam e queimarão sempre. O fogo, elemento parimi da vida doméstica, é também seu próprio fim. As casas queimam como os corpos e, diferente das moradas dos hekura, como o rochedo gerado pela fuga de Hayariwë, são perecíveis e mortais. O equívoco do Veado e a façanha do Japim, portanto, configuram-se como "uma espécie de ferramenta lógica" (Lévi-Strauss, 2008, p. 238) que opera a mediação entre pares de oposições fundamentais e constitutivas da atual humanidade: a vida breve e a existência perecível dos corpos de carne e osso associadas à madeira, e de seu revés, os seres eternos hekura, infinitos e imperecíveis, associados às pedras e montanhas. Para estes últimos, a transformação foi estabelecida desde tempos imemoriais. No outro caso, a transformação, assim como o fogo ou a mortalidade, segue eternamente. Essa oposição figura de modo sistemático inclusive no léxico metafórico yanomami (com sua maior expressão nos diálogos cerimoniais wayamou) onde "como mortais, seres humanos são associados com a floresta, árvores e habitações; em outras palavras, com elementos corporais, em contraste aos imortais hekura que são assimilados às rochas" (Lizot, 1994, p. 222). Como sistematiza Claude Lévi-Strauss, a partir dos mitos de origem da vida breve entre os Jê no Brasil Central: "A pedra, a rocha, aparecem, assim, como o termo simétrico e inverso da carne humana" (2004, p. 183).

Montanhas, pedras e rochas, assim como os picos e penhascos de rocha exposta, traduzem o termo pei maki - diferente de hehu, que é mais associado às serras e menos aos picos rochosos. Pei maki refere-se, também, às casas-montanha dos hekura, plantadas no solo da terra-floresta pelo demiurgo Omawë, bem como aos paus adornados utilizados nos processos de iniciação xamânica taamayõu, compreendido ele próprio como casamontanha dos hekura (retomaremos esse ponto adiante). Pedras e rochas, além de pei makí, são chamadas também de maa ma, incluindo aquelas em que habitam certos hekura, chamados eventualmente de maa terimi, o "povo da pedra". O classificador ma (de maa ma), especificamente, designa os objetos duros e, em alguns casos, tidos como imortais, como as pedras maa ma e o "povo da pedra" maa terimi (Lizot, 2004, p. 188; Ramirez, 1994, p. 125). Além do universo associado aos hekura, ma é um classificador que pode indicar outros elementos, como certos frutos duros, 
Fig. 66. "Hehuriwë, o espírito das montanhas, dança de uma forma muito pesada, ele é realmente pavoroso!" (Iramari Yanomami; Machado, 2014, p. 64).

Desenho de Joseca Mokahesi Poroaunahiki thëri Yanomami (2014).

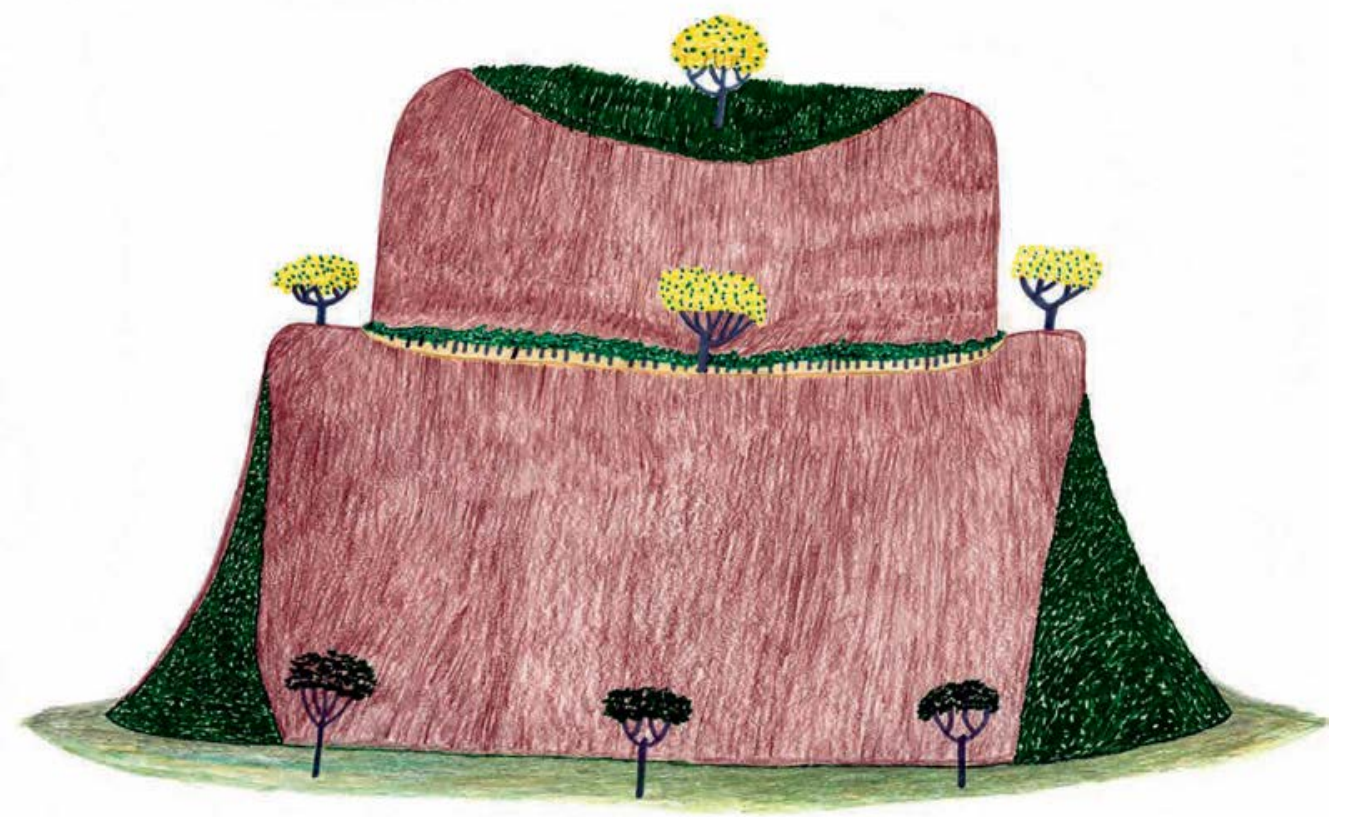


assim como suas respectivas árvores (através do classificador mahi, nesse caso), que não são imortais, mas que, pela dureza, devem ser cozidos e amolecidos para se tornarem comestíveis. As moradas rochosas dos hekura, portanto, são associadas à dureza, à solidez, à eternidade e ao imperecível. Como dizem os pajés, estas podem ser tanto de pedra como de metal, como os altos prédios das grandes cidades, mas também como as grandes árvores da floresta, de madeira dura e resistente (voltaremos nesse ponto adiante). Um exemplo de morada dura e vegetal, portanto, é o próprio paricá (pararo hi), habitado por Ihamariwë, o poderoso e respeitado serimagem Preguiça que, com sua machadinha, é considerado "o grande guerreiro dos espíritos", como me contou Francisco Pukimapiwëteri, jovem pajé do Pukima Cachoeira.

Em oposição ao classificador $m a$, associado à dureza e ao imperecível, o classificador $h i$ indica elementos de madeira e, de forma complementar, aquilo que como ela própria é por essência perecível. Esse classificador (hi) pertence ainda ao sistema taxonômico de diversas espécies vegetais, sobretudo arbóreas, assim como de espécies animais de peixes e larvas que se alimentam de madeira podre ou de insetos ortópteros da família dos fasmídeos que, como grilos e gafanhotos, se assemelham a galhos, paus e folhas. Além do mais, refere-se também à madeira, de forma geral, como no termo genérico para "pau", hii hi. Por outro lado, enquanto nome utilizado de forma metáforica, $h i$ pode se referir aos humanos falecidos e considerados, assim como a madeira, mortais e perecíveis (Lizot, 2004, p. 85). De forma complementar ao classificador hi, o classificador nahi designa variadas espécies arbóreas e certos objetos derivados dessas, como os elementos de madeira utilizados na construção da casa (Lizot, 2004, p. 244), sendo esta, possivelmente, referida também como hato nahi.

O mito sobre o surgimento dos pássaros a partir do sangue (peĩüyë pë) de Naroriwë, o ser-imagem Mucura (gambá, Didelphis marsupialis), versa sobre os processos de diferenciação entre os seres e abre um caminho interessante para desdobrarmos essa oposição entre os diferentes tipos de moradas associadas às categorias do perecível e do imperecível relacionadas, respectivamente, aos classificadores hi e ma. Nessa narrativa, em síntese, o sangue Naroriwë transformou os pássaros de seres humanoanimais em sua configuração atual, bifurcada entre os pássaros animais yaro e os seres-imagem hekura e, através da divisão da forma ancestral humano-animal e a respectiva especiação atual, introduziu aos hekura 
uma nova configuração de morada, situada e conformada pelas pedras e rochas da terra-floresta. A oposição entre ambas as classes de categorias sensíveis, perecível (da ordem da madeira) e imperecível (da ordem das rochas), é um par de ferramentas lógicas fundamental e transversal aos modos de pendurar as redes yanomami, do tapiris às montanhas, tal como vimos até então. E a partir daqui esse é o ponto em que iremos nos concentrar.

A história é assim: Naroriwë, o "feio" e "fedido", aprendeu com Hoarini, o ser-imagem Irara (Eira barbara), a soprar veneno e substâncias mágicas hëri nos outros. Diz o mito que "depois de ter observado Irara soprar veneno, o feio aprendeu e logo soprou em Mel" (Ballester, 2017a, p. 19). Mel, por sua vez, refere-se à Yamonamowãro, a imagem ancestral do mel doce das abelhas yamonã ma. A transformação humano-animal desse ser mítico, por sua vez, está associada à outra série de narrativas onde ele é incinerado na fogueira funerária no meio do xapono e as cinzas de seus ossos põem-se a voar transformando-se em abelhas yamonã ma. Yamonamowãro, diferente de Naroriwë, era um líder tido como alguém muito bonito, elegante e cheiroso:

Onde ele passava, deixava seu perfume, pois o cheiro dele era como o dos cabelos das mulheres que os Yanomami acham tão bonitas que desejam ir aos xapono delas para se casarem (Ballester, 2017a, p. 19).

Hoarini, o Irara, por sua vez, apresentou as substâncias hëri ao Naroriwë e com isso ensinou também os Yanomami a manipulá-las, o que se relaciona, inclusive, com um detalhe comportamental da irara enquanto animal onívoro e conhecido também em português como papa-mel, sendo este um de seus alimentos prediletos. Naroriwë, o "feio", tinha ciúmes das duas mulheres que admiravam a beleza e o perfume de seu marido Yamonamowãro e o seguiam por toda a parte:

Ao avistar as duas mulheres, cheias de desejo e se dirigindo apressadas à casa de Mel [Yamonamowãro], Mucura [Naroriwë] se zangou. Ele era mesquinho e, assim, ensinará os feios a matar os bonitos. Indiretamente, as duas mulheres entregaram Mel à Morte (Ballester, 2017, p. 20).

Raivoso, apressou-se a pedir e pegar o veneno com Hoarini e partiu obstinado à casa de Yamonamowãro, onde soprou e matou-o. Em síntese, após o ocorrido e

ensinando o choro aos Yanomami, elas duas logo choraram, 
choraram, pensando nele. [...] Ele [Naroriwë] fugiu. As duas mulheres cremaram o corpo de Mel [Yamonamowãro] e, enquanto o cremavam, o feio fugiu para se esconder, como se fosse escapar. [...] Mucura [Naroriwë] se escondia na montanha, ele foi lá em cima, porque queria escapar. Ele subiu em uma árvore. A montanha era redonda como um jutaí [jatobá, Hymenaea courbaril], ele entrou lá, onde a montanha tinha uma fenda. Pretendia se trancar ali. Eles derrubariam a montanha para pegálo. [...] Chamaram os do grupo dos tucanos Parawari, porque o grupo das Maitacas não conseguiam. Os Araris [pajés-Arara] estavam tendo dificuldades com seus machados de pedra, que se destruíam. Apesar dos machadinhos dos Tokorari, todos sofriam por causa das ferramentas, que se quebravam em pedaços e não entravam na pedra. Chamaram os do grupo Parawari [...]. Eles chegaram e atacaram a montanha. [...] Para poupar esforços inúteis, eles amoleceram a parte interna da montanha, como se fosse uma árvore, com a força do pensamento. [...] Depois de amolecer a pedra, derrubaram uma parte. [...] A montanha era do tamanho de uma sumaúma [Ceiba pentandra]. [...] Fizeram outro buraco grande, para poderem continuar com a destruição da pedra. [...] Conseguiram fazer esse buraco porque os Parawari têm esse bico mais comprido, e que será mais comprido para sempre. [...] O bico do tucano empoleirado é, na verdade, seu terçado (Ballester, 2017a, p. 25-30).

O local onde Naroriwë se escondeu varia entre as diversas versões registradas dessa longa narrativa. $\mathrm{Na}$ versão na qual me baseio e resumo aqui, coletada e traduzida por Anne Ballester (2017), assim como nas versões de Jacques Lizot (Wilbert; Simoneau, 1990, M133/M134) e Franz Knobloch (Wilbert; Simoneau, 1990, M139), Naroriwë esconde-se numa grande rocha, redonda como o jatobá e grande como uma sumaúma. $\mathrm{Na}$ versão de Luis Cocco (Wilbert; Simoneau, 1990, M131), por exemplo, o elemento montanha é substituído por uma grande árvore mai kohi. A espécie indicada nessa versão alternativa do mito refere-se ao ipê, também conhecido como ipê-amarelo-do-cerrado (Tabebuia ochracea), cujas madeiras são de grande resistência, além de duras e pesadas, o que corresponde ao classificador ma que designa objetos propriamente duros, como pedras, árvores e frutos. Este classificador, como vimos, associa-se ao universo dos hekura, imortais e, por sua vez, relacionados às pedras (Lizot, 2004, p. 85; Ramirez, 1994, p. 125). Desta maneira, se em um 
conjunto de versões compara-se a escala e a forma da rocha onde Naroriwë se esconde com as grandes árvores da floresta, em outro a árvore onde está Naroriwë é dura como pedra, compartilhando dessa característica sensível e fundamental.

As relações mútuas entre as características sensíveis dos animais da atualidade e as propriedades e ferramentas míticas desses seres também são dignas de consideração. Assim como na versão de Ballester (2017) foi necessário chamar os seres-imagem Tucano, Parawari - cujo comprido bico "é, na verdade, seu terçado" (Ballester, 2017a, p. 30) -, na versão de Cocco se explica porque todos os pássaros que tentaram anteriormente derrubar a dura árvore possuem, desde então, bicos pequenos: "todos começaram a cortar com seus machados [seus bicos] até que estivessem todos gastos" (Wilbert; Simoneau, 1990, p. 238, M131). Com a intervenção de Parawari, junto dos outros diversos pássaros ancestrais "tristes por estragar seus terçados", o trabalho surtiu efeito e "começaram a fazer a montanha balançar" (Ballester, 2017a, p. 30). Segundo a narrativa: "Só faltava o coração da montanha. Os terçados sendo curtos, esse pedacinho ainda resistia. Apesar de pequeno, o tronco da montanha não quebrou rapidamente" (Ballester, 2017a, p. 30). Para concluir o feito, convocaram o poderoso Preguiça, Ihamariwë:

Queriam que ele puxasse a ponta da montanha, pois a montanha não caía. Preguiça esticou um fio flexível e puxava a montanha. [...] Com o fio, parecido com linha de pesca, ele puxou o cume da montanha. [...] A pedra começou a estourar, fazendo um barulho enorme; parecia cair um pedaço grande de céu. [...] Tuuuuuuuuuuuu, tẽẽẽrërërërë! [...] Eles destruíram Mucura. Todos os animais, as araras, os tucanos, os urus, os inambus, os mutuns, os jacus, os urumutuns, os mutuns-de-traseiro-vermelho e os jacamins eram gente. Todos juntos, pegaram aquele que foi destruído. Chegaram até o sangue de Mucura derramado no chão para se pintarem. [...] Todos os passarinhos são diferentes: uns são vermelhos, outros cinzentos, outros têm pálpebras cinzentas. As cores dos pássaros vêm daquele momento, quando se transformaram em animais, naquele mesmo lugar, com o sangue derramado (Ballester, 2017a, p. 31-32).

Transformados em animais, os pássaros e o próprio Preguiça que acabavam de se pintar com o sangue do Mucura, tampouco retornaram aos respectivos xapono. Com o sangue, portanto, definiu-se a separação 
de quando estes "eram gente" e "quando se transformaram em animais": "De tanto se pintarem com o sangue derramado, ele acabou e, depois de terminarem, logo voaram. Logo se transformaram. Eles ocuparam a floresta toda, não restou nenhum espaço" (Ballester, 2017a, p. 32). Na versão coletada por Lizot, entretanto, há um desdobramento complementar no final dessa história. A transformação de gente-animal, como sugere esta versão, é apenas uma das facetas da narrativa, já que ao mesmo tempo transformaram-se também nos espíritos hekura e, portanto, ao migrarem para a floresta, animais e espíritos, largando o xapono próprio de uma certa humanidade mítica, passaram a habitar moradas outras. No caso dos espíritos, segundo a narrativa, foi a partir desse momento que as pedras e as rochas passaram a ser habitadas pelos hekura, pois até então eram completamente desabitadas:

"Vamos lá!" Eles se juntaram e transformaram-se em espíritos hekura. Um velho primeiro mandou os tucanos para irem viver nas rochas. "Você vai viver ali. Você vai viver naquela rocha. Você aí vai viver nessa daqui. Você vai viver nessa aqui". Ele mandou todos embora, inclusive um que parecia um velho e sábio homem. Um atrás do outro, ele mandou todos embora. "Vocês vão todos ocupar as rochas; a partir de agora vocês vão viver nas rochas", ele disse a eles (Wilbert; Simoneau, 1990, p. 256, M133).

Nota-se, com isso, que, assim como o líder Koparisini (Gavião) deliberadamente dividiu a terra, transmitiu o kãwãamou e, assim, ensinou os Yanomami a morar no xapono (cf. "Viver junto"), de modo simétrico e inverso, Naroriwë indiretamente dividiu os pássaros através de seu sangue e introduziu aos hekura uma nova morada na pedras e rochas da floresta. Através do sangue, entretanto, há outras correlações significativas, nesse caso, entre o mito sobre o surgimento dos pássaros pelo sangue de Naroriwë e o mito da origem dos Yanomami pelo sangue de Periporiwë (cf. "Sangue da Lua"). Se no pensamento yanomami o sangue (pei ĩyë pë) corresponde a um componente fundamental da pessoa e fonte de energia vital (Albert, 1985, p. 348-349), poderíamos especular através do mito que se trata também de um componente que opera a distinção entre espécies ou tipos "mais guerreiros" e "menos guerreiros", seja através das cores e dos locais em que são aplicadas no corpo humanoanimal, seja através da quantidade e dos locais na qual o sangue caiu no território. De modo complementar, no mito de origem da noite (cf. "Viver junto"), é também através do sangue de Titiri, "demônio da noite" 
associado ao antepassado mítico do mutum (Crax alector), que dá origem aos seres maléficos Weyari, os "demônios da manhã", e Kõimawë, o "falcão canibal" (Lizot et al., 1993, p. 83). Assim como no mito do surgimento dos pássaros, então, o sangue enquanto substância vital associa-se aos vivos e, por outro lado, o sangue destituído do corpo enquanto pintura ou gotas caindo do céu, também como no caso do ser da noite Titiri, associa-se à transformação propriamente dita. Nestas narrativas, portanto, a função do sangue poderia ser lida enquanto operadora do estabelecimento da alteridade e da diferença, ou seja, a definição de um outro através de relações de contraste e distinção. Pela mesma lógica que se diferenciam os corpos, porém, diferenciam-se também as moradas - do xapono ao pei maki - de modo que as transformações míticas e as operações lógicas, agenciadas pelas narrativas que analisamos, resultam assim na oposição fundamental entre os seres e suas moradas, associados às categorias do perecível e do imperecível.

Como ressalta Lizot, analisando o mesmo mito de Naroriwë, foi com esse direcionamento - e segundo complementa, dado por Ihamariwë (Preguiça) - para que os ancestrais humano-animais fossem morar nas rochas das montanhas que estes se converteram em seres imortais: "Esses seres viraram hekura, vivem nas pedras, nas paredes rochosas das montanhas, e por isso são imortais, pois a rocha, assim como a madeira que não apodrece, está associada à eternidade no pensamento indígena" (Lizot, 2011, p. 150). As rochas transformadas em casa e que passaram a ser habitadas pelos ancestrais hekura, referidas também como o "peito das montanhas" (pei pariki, "peito"), foram assentadas no solo da terrafloresta durante a fuga e o desaparecimento mítico do demiurgo Omawë. São os "rastros" e as "obras" de Omawë (ou Omama, na língua yanomam): "Aquelas montanhas que vocês chamam de 'seha' [distorção da palavra 'serra', em português] são os rastros que Omama deixou para trás durante o seu voo. Todas as muitas montanhas na floresta são obra de Omama" (Wilbert; Simoneau, 1990, p. 417, M11). Essa história encerra o ciclo de feitos extraordinários do demiurgo Omawë (ou Omama) e poderia ser resumida da seguinte maneira.

Após a 'criação' dos seres humanos e da estabilização e fixação da terra-floresta, Omawë desapareceu. Segundo uma das narrativas míticas a respeito desta fuga, diz-se que enquanto cuidava de sua roça, a fim de prover água para seu pequeno filho, Omawë fura o chão, fazendo com que 
as águas de um lago do patamar subterrâneo jorrem aos céus, dando origem aos rios e determinando seus percursos, no momento em que iniciaram seu fluxo descendente, terreno abaixo: "Omama [m.q. Omawë] ordenou a floresta. Desde aqueles tempos os rios permanecem como Omama os fez. Antes não havia rios no patamar terreno; não havia água" (Wilbert; Simoneau, 1990, p. 405-407, M202). Em seguida, após ser avisado por seu filho sobre a ameaça de um ser maléfico sobrenatural, vindo da floresta na direção de Omawë e sua família (erroneamente confundido com o canto de um pássaro Hypocnemis cantator), Omawë fugiu pelos ares, voando acompanhado de seu irmão Yoasiwë e sua família: "Ele desapareceu assim para sempre. Ele já tinha nos tornado em Yanomam [subgrupo do narrador deste mito], e foi por isso que foi embora e não pode mais ser visto" (Wilbert; Simoneau, 1990, p. 415-416, M210). Assustado com a suposta perseguição pelos seres maléficos plantou imensas palmeiras de bacaba (Oenocarpus bacaba), a fim de ocultar seus rastros. As palmeiras se transformaram, imediatamente após serem arremessadas e plantas por Omawë, nas montanhas e serras dispersas na atual terra-floresta habitada pelos Yanomami. De acordo com a narrativa sobre a origem das montanhas, teria sido este ato, com o intuito de desorientar o ser que o perseguia, que fez com que a floresta tomasse o atual caráter inóspito, em oposição a acolhedor e doméstico das habitações yanomami: "Omama era um ser supernatural, e colocou a floresta em um mal estado durante o seu voo para desviar o perseguidor de seus rastros" (Wilbert; Simoneau, 1990, p. 417-418, M211).

Com a fuga, de acordo com as narrativas mencionadas, Omawë teve como destino final a região limítrofe da urihi, isto é, onde a floresta acaba, onde não há mais árvores, onde a terra torna-se areia, onde o Rio Orinoco acaba e mergulha no subterrâneo e, enfim, onde teriam sido criados também os napë. Segundo Adriano, esta é a região situada "nas bordas da terra (...) onde os rios e o céu entram dentro da terra, lá onde o céu é apoiado com fortes esteios de metal, que não enferrujam nunca" e onde Omawë atualmente mora, "onde ele segura o céu para que ele não caia". Foi com este último feito de Omawë, portanto, que as casasmontanhas dos hekura foram criadas. Como ressalta Davi Kopenawa: "Omama criou as montanhas para esconder o caminho que tomou ao fugir. Elas não estão na floresta à toa. Embora pareçam ser impenetráveis aos olhos de quem não é xamã, na verdade são casas de espíritos" (2015, 
p. 91). No entanto, segundo Adriano, os hekura não moram apenas nas paredes rochosas das montanhas (pei maki). Como vimos anteriormente, é também nos pés de paricá (pararo hi) onde habita Ihamariwë e, de acordo com Adriano, os hekura "moram também nas cachoeiras, nas cabeceiras dos rios e remansos; nas grandes árvores da floresta, sumaúma, angelim". Adriano, entretanto, destaca que é nas montanhas onde moram os "pajés [espíritos hekura] perigosos" (como vimos no capítulo "Terra-floresta"), como frariwë (Onça). Segundo Francisco, irmão de Adriano, é ainda nas cabeceiras dos rios onde mora Moturiwë, ser-imagem das águas ou dos aquíferos (como as águas subterrâneas que Omawë mobilizou para fazerem emergir os rios), "quem faz e deixa a água limpa, potável, mas o branco não sabe disso e por isso destrói”.

O que se destaca com essas múltiplas possibilidades de morada dos hekura na terra-floresta, para além das paredes rochosas, contudo, é justamente o caráter de dureza e, consequentemente, de permanência (parimi) de tais locais: das grandes árvores (extensíveis, inclusive, ao uso do morfema $m a$, associado às rochas), mas também nas cabeceiras de rios, cachoeiras e nos aquíferos permeados de rochas, pedras e seixos de distintas naturezas. Essa diversidade de moradas (hekura pë yahipi, "casas de espíritos") possíveis refletem, portanto, a multiplicidade intensiva dos inúmeros tipos de seres-imagem (hekura) que habitam a terra-floresta e que podem ser convocados enquanto aliados dos pajés, sendo cada um deles diferenciados pelo pensamento mítico e xamânico através de uma infinidade de minuciosas descrições sobre suas características, qualidades e potências. Essas descrições extrapolam os limites desse trabalho, mas, como aponta Reig, constituem-se em um "armamento versátil [versatile weaponry]" passível de ser mobilizado pelos pajés e que reflete esse complexo "sistema de qualidade sensoriais", relacionadas, assim, ao "envolvimento íntimo com a materialidade do ambiente [environment]" (2013, p. 231). Envolvimento notável, por exemplo, através dos múltiplos locais de morada relacionados ao sistema de qualidades e potências específicos a cada um dos seres, como exemplificado pela breve descrição de Moturiwë.

Concepções análogas em torno das montanhas e das rochas como moradas extra-humanas eimperecíveis - em oposição às perecíveis moradas humanas - são presentes em diversas sociocosmologias indígenas. Entre os Tukano, do Noroeste Amazônico, as montanhas são concebidas como 
grandes malocas, de feições uterinas, e como moradas dos animais de caça da floresta (Reichel-Dolmatoff, 1971, p. 99). Entre os Trio, da região das Guianas, as encostas rochosas, penhascos e montanhas são concebidas, de forma análoga aos Yanomami, como casas de espíritos e dos animais dos tempos primeiros (Rivière, 1995, p. 196). Como notam Janet Carsten e Stephen Hugh-Jones sobre os povos da Guianas (dentre eles os Trio):

[...] Não há posses ancestrais herdadas e nenhuma unidade social duradoura que perdure além da vida dos líderes que constroem as casas as quais as comunidades se identificam. As únicas casas duradouras são as montanhas, as moradas dos espíritos invisíveis [invisible spirit beings]; as povoações humanas [human settlements] são apenas evidências transitórias dessas casas permanentes (1995, p. 35).

Entre os Ye'kwana - como brevemente mencionado no capítulo "Casaaldeia" -, conta-se que a casa que o demiurgo Wanadi construiu para si - a primeira maloca (atta) conhecida por Attawanadi -, a fim de demonstrar aos Ye'kwana como se constroem as verdadeiras casas coletivas (atta), ainda pode ser vista em meio à floresta sob a forma de uma montanha cônica localizada no centro do território (Guss, 1990, p. 21). De acordo com Peter Rivière, referindo à região das Guianas e especificamente aos Ye'kwana, "há em toda a região uma associação comumente feita entre rochas e montanhas (frequentemente consideradas como casas de espíritos ou donos da caça), permanência e durabilidade, e o mundo invisível" (1995, p. 201). Mas, nesse caso, para além da casa-montanha mítica de Wanadi e a sua dupla contraparte invisível, obra do mesmo demiurgo, os Ye'kwana afirmam que todas malocas (atta) possuem um duplo invisível (Guss, 1990, p. 21), de modo que, como argumenta Rivière, as moradas humanas (ou as "povoações", settlements)

são fenômenos fugazes [...]; são descontinuidades espaciais e temporais em um mundo visível que é, em certo sentido, contingente a uma realidade invisível [...]; são a evidência visível mas efêmera de uma continuidade invisível (1995, p. 202).

De modo distinto da maloca ancestral e prototípica (Attawanadi) dos Ye'kwana, as potencialmente infinitas moradas dos hekura (hekura pë yahipi) nas montanhas (pei maki) e noutros lugares rochosos ou duros não são concebidas como protótipos das moradas humanas (xapono), muito embora afirme-se que os hekura partilham da mesma sociabilidade e, com isso, do mesmo modo de habitar que os Yanomami, ainda que 
de modo invisível aos olhos da gente comum e não-pajé. Nesse sentido, assim como o círculo de paricás (pararo hi) que rodeiam o espaço do xapono é visto pelos hekura ("espíritos" e pajés) como as roças e as casas de Ihamariwë - tal como relatei em detalhes mais acima -, as "casas de espíritos" (hekura pë yahipi) bifurcam os referentes possíveis e multiplicam o sentido da sociabilidade e habitabilidade do xapono não através de uma cópia prototípica mas de uma variação posicional e escalar.

Entre os Yanomami, os xapono tampouco possuem duplos invisíveis, como é o caso das malocas (atta) ye'kwana. No entanto, através dos pajés hekura (essenciais na constituição do xapono enquanto tal, assim como vimos no capítulo "Casa-aldeia") e das moradas de seus espíritos auxiliares (hekura pë yahipi) construídas em seu peito (como veremos adiante), é estabelecido uma conexão entre o xapono, nos termos de Rivière, "a evidência visível mas efêmera" e sua "continuidade invisível" e imperecível. Logo, essa conexão não se dá como na forma-duplo, relacionando o xapono a um duplo externo e invisível, mas através de uma multiplicidade interna, no sentido de uma variação posicional e escalar em que que dentro de um mesmo xapono (perecível) há potencialmente inúmeros outros xapono (quase-imperecíveis, como veremos adiante), já que pode haver tantas "casas de espíritos" (hekura pë yahipi) quantos pajés houverem. Cada uma destas, ainda, contendo não só muitas casas dentre de si (como em um enorme xapono, veremos a seguir) como também sendo parte de uma rede muito mais complexa de outras "casas de espíritos" de outros pajés ou de outros seres e locais da terra-floresta. Nesse sentido, é através da iniciação xamânica que o pajé (hekura) acessa a contraparte invisível e imperecível do xapono, isto é, as "casas de espíritos" (hekura pë yahipí) situadas em seu próprio peito e, como relatam os pajés, feitas tanto de pedra quanto metal.

Uma concepção próxima a esta, em que a mediação com a contraparte invisível e imperecível da morada visível e perecível é pautada pelo corpo do pajé, pode ser notada também entre os Guarani Mbya. Segundo Daniel Pierri, as "cidades celestes" habitadas pelos demiurgos são feitas de pedra e concreto, assim como a cidade dos brancos, e por essa razão, são idealmente imperecíveis e eternas (2013, p. 160). Assim, "a figura das táva [ruinas das antigas missões jesuíticas] ocupam um papel de destaque na mediação entre o mundo terrestre e os mundos celestes justamente por sua imperecibilidade" (Pierri, 2013, p. 113). E como relata Pierri: 
Em uma das explicações que obtive sobre esse tema, um interlocutor me explicou que as táva foram no passado casas de reza (opy), como qualquer outra, com as paredes de madeira preenchida por barro, e a cobertura vegetal, mas que se transformaram em casas de pedra no momento em que o rezador que nela praticava seus rituais conseguiu atingir o estado de aguyje [transformação do corpo do pajé em um corpo imperecível e imortal]. Transformamse simultaneamente em imperecíveis, nessa versão, o corpo do recém-tornado Nhanderu Mirĩ [este termo refere-se aos homens que tornaram-se divindades] e aquele da sua casa de rezas (opy), que ficaria na terra como exemplo (2013, p. 163).

Entre os Yanomami, por outro lado, é através da iniciação xamânica (chamada de taamayõu entre os Yanomami do Marauiá) que o iniciado se torna, ele próprio, hekura. Com isso, a "imagem" (no uhutipi) da pessoa adquire também uma dimensão eterna, já que depois da morte do corpo, sua imagem essencial pode ainda ser convocada por outros pajés hekura. Ao mesmo tempo, é com o primeiro taamayõu que a "casa dos espíritos" (hekura pë yahipi) será feita pelos hekura no peito do pajé, mas, apesar das descrições sensíveis e virtualmente materiais dessas casas sendo de pedra ou metal, assim associada à dureza e à durabilidade, tais moradas não resultam ou replicam-se em uma versão terrena, como as táva nas narrativas guarani mbya, e tampouco são exatamente ou totalmente imperecíveis. Isso, pois, os seres hekura demandam do pajé uma contínua manutenção de seu corpo-casa e, com isso, das relações com seus espíritos auxiliares, isto é, aqueles que já o habitam. Tal manutenção se dá, por exemplo, através de outros processos de iniciação (taamayõu) que o pajé pode se engajar, mas também através do uso contínuo do epena e da prática constante do hekuramou. Além disso, com a morte do pajé, sua casa de espíritos tem um fim determinado tal como corpo, mesmo que num plano virtual. Como explica e resume Kopenawa:

Quando um xamã [m.q. pajé] fica muito velho e não quer mais viver, ou quando está muito doente e perto de morrer, seus xapiri [m.q. hekura] se afastam dele. Ele então fica sozinho e vazio, antes de se apagar como uma brasa de fogueira. Depois, uma vez abandonada, sua casa de espíritos desaba por si mesma. É assim que acontece. Os xapiri de um xamã vão embora quando seu pai morre. Voltam para onde viveram antes, nos morros e montanhas da floresta e nas costas do céu. Só voltam para os humanos muito tempo depois, para dançar para um outro xamã, muitas vezes 
filho do xamã que deixaram (Kopenawa; Albert, 2015, p. 489).

Assim, nota-se que as casas dos espíritos, ou a imagem das casas no corpocasa do pajé, apesar de sua escala e materialidade durável (como veremos em detalhes a seguir), tem um tempo de vida determinado e, portanto, quase imperecível, cujo fim é consonante com a existência perecível do corpo do pajé na qual se situam. No entanto, os hekura - os seres imagens feitos espíritos auxiliares - permanecem em uma virtualidade latente e implicam, assim, tanto em um controle de sua potências pelos outros pajés - no âmbito da morte e também do rito funerário do pajé morto, em que estes podem se mostrar potencialmente perigosos e raivosos -, mas, também na possibilidade de serem, num certo sentido, capturados ou abrigados em outros corpos-casas, de forma cíclica e contínua.

O processo de iniciação xamânica taamayõu (relatado em detalhes também por outros autores, por exemplo, Kopenawa; Albert, 2015, pt. I, "Devir outro"), consiste, essencialmente, na transmissão de conhecimentos, cantos e casas ("casa de espíritos", hekura pë yahipi) entre o pajé mais experiente, o "professor" como dizem no Marauiá, e a pessoa que pretende se iniciar pela primeira vez ou aprofundar seu conhecimento, o "aluno". O início desse processo é consoante à preparação do corpo do "aluno" através de uma dieta e de prescrições alimentares específicas e rigorosas. Controlado pelo pajé "professor", o "aluno" passa a ter uma dieta restrita à líquidos, conforme me explicou o jovem pajé Francisco do Pukima Cachoeira, com pequenas doses de vinho de bacaba, açaí, pupunha ou buriti. Além disso, adere à prescrições em torno da higiene, ficando restrito de tomar banho, e também de ter relações sexuais. Essas prescrições antecedem em parte o início do processo, preparando o corpo que será iniciado de acordo com as orientações dos pajés mais experientes, e acentuam-se com o consumo de grandes doses de epena durante todos os dias do taamayõu, que costuma durar em torno de uma semana. Com essas medidas, intenta-se que o corpo do pajé esteja limpo para tornarse atrativo aos hekura que têm aversão à sujeira e às impurezas terrenas (como notamos no capítulo "Casa-aldeia", na descrição do xapono heha, o "meio do xapono"). Garantidas assim às condições de limpeza, o futuro pajé deve se enfeitar, pintando-se de urucum, colocando seus adornos e emplumando a cabeça com penas de gavião para então iniciar o taamayõu.

Após as prescrições voltadas ao preparo do corpo, nos primeiros dias do taamayõu o processo de limpeza do interior de seu corpo segue 
Fig. 67. "Quando um xamã yanomami está a beira da morte, quando as casas de seus xapiripë começam a quebrar, então o espírito do macaco-aranha as segura para que elas não desabem" (Iramari Yanomami; Machado, 2014, p. 63). Desenho de Joseca Mokahesi Poroaunahiki thëri Yanomami (2014).

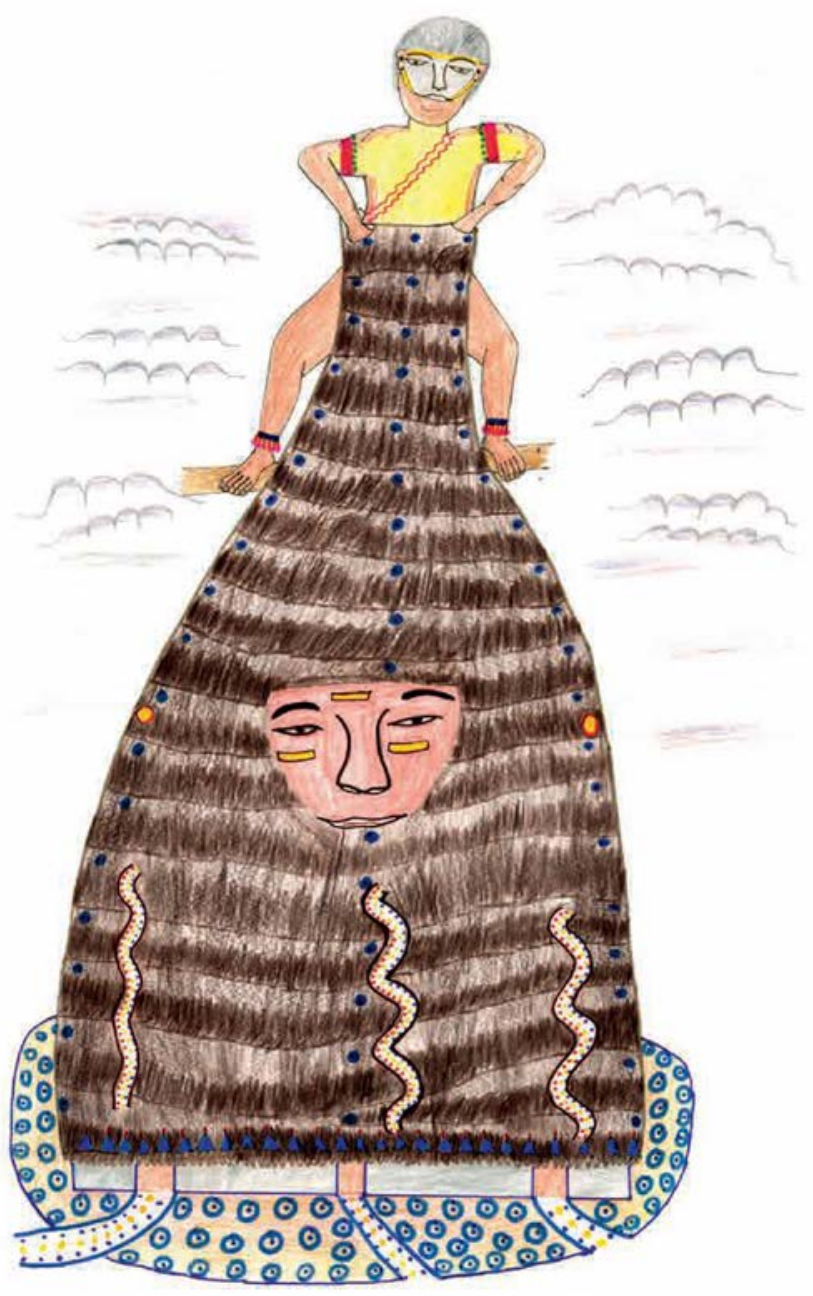


mediado pelo "professor" e pelos primeiros seres-imagem hekura que são convocados ao pajé que se inicia. Como nota Maria Inês Smiljanic, as imagens das plantas são os primeiros hekura convocados ao pajé neófito pelo "professor", como os seres-imagem das palmeiras bacaba - aquelas plantadas pela fuga do demiurgo e que deram origem às montanhas - e também de espécies próximas do ubim que, se no plano cotidiano serve para cobrir as casas e tapiris, no processo de iniciação xamânica, conforme a autora, "constituem o primeiro abrigo construído para os espíritos auxiliares durante a iniciação" (1999, p. 67). Como me explicou Francisco, falando sobre sua própria iniciação, o taamayõu "começa com uma limpeza feita pelos hekura, como a limpeza de uma roça, para preparar o terreno da casa que será construída no corpo do pajé".

Segundo uma narrativa de Cândido, grande pajé do Pukima Cachoeira - mediada pela tradução livre feita por Francisco, seu filho e também seu "aluno" -, no início os pajés "fazem a limpeza, como do tamanho desse xapono, bem limpinho mesmo, para poder vir os espíritos no corpo da pessoa". Nessa narrativa sobre o processo de iniciação xamânica, Cândido estabelece, assim, uma correspondência entre "o curso de pajé" (taamayõu), o "como fazer as casas" (yãatamotima) e, não por acaso, a "construção de uma escola" - justamente o tema da assembleia que terminava a pouco, conforme mencionado na "Apresentação" desse texto. De noitinha, começando a história, ele dizia assim:

Para virar hekura [hekuraprou] tem que primeiro construir a casa, como a construção de uma escola para dar aula, a casa de quem vai aprender. Quem quer aprender tem que aprontar uma casa grande. No piso, tem que deixar a terra bem plana, como se fosse o banco do aluno. Assim que terminar toda a casa, o piso e o telhado, o aluno pode começar a cheirar paricá [epena, substância feita a partir das sementes da Anadenanthera peregrina]. Sopram o paricá e esse é o início da aula. Para soprar o paricá no aluno tem que fazer bem certo, como um caminho. Tem que soprar bem certo para o caminho vir direto para o peito do aluno e não espalhar, para não errar o caminho dos espíritos.

Um bom caminho para se aproximar da analogia feita pelo hekura entre (1) construir uma casa, (2) como uma escola, (3) para aprender a ser pajé, é o modo pelo qual o conceito de escola é traduzido pelos Yanomami por hiramotima nahi. Hira- é raiz verbal partilhada pelo verbo transitivo hirat, que significa "ensinar" ou "dizer a alguém como 
fazer algo", e o verbo intransitivo hiraat, que quer dizer "juntar-se", "reunir-se", "agrupar-se" e "viver em" (Lizot, 2004, p. 209). Já o sufixo -motima, como vimos em yãatamotima, transforma o verbo em nome e, assim, transforma o "ensinar" e o "juntar-se" em um "lugar de ensinar", a escola. Nahi, por sua vez, é um classificador nominal que designa certas espécies arbóreas bem como seus derivados, como objetos ou elementos construtivos de madeira, inclusive as casas e acampamentos temporários na floresta, hato nahi (Lizot, 2004, p. 244). Nesse caso, nahi enfatiza o sentido complementar de a "casa da escola", ou seja, a construção na qual ela está estabelecida somada à instituição e ao conjunto de saberes que a constitui enquanto tal. A escola é então pensada como a "casa do ensinar" e comparada à casa feita pelo "aluno" para o taamayõu, mas, também, ao que me parece, como metáfora para a própria casa que será construída em seu peito durante esse processo. Em todos os casos, entretanto, o processo de transmissão de conhecimento orienta-se a partir de um lugar situado e específico; além disso, compartilham entre si critérios estéticos ideias. A casa-escola, então, tem de ser feita "bem certo", tem que ser "grande", "bem plana", seguindo o jeito apropriado de se fazer, de se ensinar e de se aprender.

De modo complementar, a relação com o processo de iniciação dos pajés, o taamayõu, pode ser pensada através da extensão semântica e epistêmica da noção de hirai, "ensinar". O verbo intransitivo hiramou, por exemplo, é composto pela raiz hira- e pelo o morfema intransitivizador -mo- que implica em um movimento de repetição ou regularidade e indica a voz passiva analítica da pessoa que se faz "ser ensinada", "ser mostrada como fazer" ou ainda "ser iniciada como pajé" (Lizot, 2004, p. 232). O "curso de pajé" (taamayõu), em particular, é concebido como o modo por excelência de "ser ensinado". Ao longo de vários dias, o pajé "professor", como dizem, conduz o "aluno" ao aprendizado direto com os espíritos hekura, através da mediação estabelecida por ele, manejando a rigorosa dieta, as doses sopradas de paricá e o próprio contato e diálogo travado com os hekura. Os espíritos hekura, portanto, transmitem ao "aluno" seus múltiplos cantos e, no fim desse processo, constroem em seu corpo suas próprias casas. O corpo é onde se reúnem os espíritos auxiliares do pajé; é através dele que são transmitidos os conhecimentos e, da perspectiva destes espíritos, o corpo é uma clareira para a construção de suas casas, chamadas de hekura pë yahipi, "casas de espíritos". 
Como sugere José A. Kelly Luciani, os pajés têm a habilidade de assumir outros pontos de vista e, através da perspectiva dos espíritos, isso permite que estes se engajem, dialoguem, ensinem (no caso do "professor") e aprendam (no caso do "aluno") com eles, durante o taamayõu. De maneira análoga, a escola e seus respectivos alunos, "têm uma faculdade similar, a saber, a capacidade de assumir a posição do napë a fim de manejar as relações com eles" (Luciani, 2011, p. 80), traduzindo o mundo dos napë para os demais Yanomami, a fim de tornálo minimamente apreensível e, com isso, controlável. Esse procedimento tradutório, e propriamente xamânico (cf. Carneiro da Cunha, 1998), de transformar o desconhecido em algo que ressoe como apreensível, através de correspondências e variações de pontos de vista, da perspectiva dos hekura à dos napë, foi o jeito elaborado por Cândido para começar a me explicar o complexo processo do taamayõu ("curso de pajé"). O que ele faz, assim, é uma tradução daquilo que para si e para os espíritos hekura constitui seus modos de produzir e transmitir conhecimento para aquilo que me era próprio, variando também seu ponto de vista e associando-se ao nosso universo conceitual onde a imagem da escola, da escrita e do papel constitui o modo apropriado de transmitir conhecimento. Assim, se o conhecimento dos pajés é fundamental para a manutenção das alianças com os diversos seres que coabitam a terra-floresta, a escola é também fundamental para a mediação das relações com os napë. A aproximação de ambos universos tece "conexões parciais" (Strathern, 2004) e alianças pragmáticas (Almeida, 2013) entre esses mundos distintos e sugere também formas complementares de se relacionar, de ensinar e de aprender.

Seguindo com a narrativa de Cândido, grande pajé do Pukima Cachoeira, no início os pajés "fazem a limpeza, como do tamanho desse xapono, bem limpo mesmo, para poder vir os espíritos no corpo da pessoa". Em seguida, com o corpo e o peito do "aluno" limpo como o xapono, como compara Cândido, os pajés e seres hekura "vão fazer ainda o caminho, para poder vir corretamente para a pessoa, para ser pajé mesmo". Esses caminhos são associados ao sopro do epena nas narinas do pajé que está sendo iniciado, de modo que "para soprar o paricá [epena] no aluno tem que fazer bem certo, como um caminho, encaixar bem certo para o caminho vir direto para o peito do aluno e não espalhar, para não errar o caminho dos espíritos". Além disso, ressalta Cândido, estendendo à analogia com a escola, tais caminhos devem ser bem traçados para que 
os hekura possam "seguir como se fosse uma estrada, para não errar, para poder seguir certinho, como se fosse uma fileira de cadeiras em que cada um fica no seu lugar". Dentre os hekura que fazem essa limpeza e preparam o corpo-terreno e os primeiros sopro-caminhos, Cândido menciona - dessa vez em outra narrativa traduzida livremente por Mauro, seu neto - os seres-imagem das árvores wahara hi (inharé, Helicostylis tomentosa) que abrem "a clareira no peito", abrindo espaço à chegada dos outros hekura. Segundo ele, estes aparecem queimados e pretos, como árvores queimadas no processo de coivara de abertura das roças e, assim dizia-me, "aparecem igual a escrita, como as letras no papel, igual você está escrevendo ele vai aparecendo, assim que é a casa dos espíritos".

Com a abertura do peito-clareira e com o devido traçado dos sopro-caminhos, estes que serão percorridos pelos diversos outros hekura convocados a habitar o peito do pajé, o processo de iniciação segue, conforme Cândido (traduzido por Francisco), da seguinte maneira:

Daí eles [os pajés] vem trazendo as casas deles [dos seresimagem, "espíritos"] nesse caminho para o peito do rapaz. O pajé [o "professor"] tem que receber paricá também para poder chamar os espíritos que já trazem a sua própria casa, chamando os nomes dos que vão trazer sua casa para morar no peito. Daí ele [o "aluno"] vai caindo e levantando [por conta da fraqueza e das fortes doses de epena, combinado à agência e o impacto dos hekura sobre o corpo, como veremos adiante] e ele [o "professor"] fala outro nome do que vai vir de novo. Daí chama outro nome de novo, e vai seguindo, falando o nome de quem vai vir. Para ele [o "aluno"] poder entender quem vai vir. Quando vem já traz a casa prontinha. O pajé tem que soprar e também cheirar para poder trazer a outra casa. Mesmo que pesada, ele vai trazendo, trazendo, trazendo, mesmo que caía no chão. E vai trazendo, o pajé vai organizando e colocando os espíritos no peito do rapaz. Traz também outros espíritos, os que ficaram para trás. Sopra, levanta, traz mais casas e vai fazendo isso. Quem quer ser pajé mesmo tem que cobrar o pajé que está dando os hekura para você. Tem que cobrar para dar mais, pedindo para ser um grande pajé para ficar como ele, trazendo as casas dele próprio e pedindo mais ainda. Para ser pajé tem que enxergar mesmo e pedir para o pajé para enxergar melhor os espíritos. Assim que os pajés fazem. Através desse processo, que se alonga até o último dia da iniciação (cuja singularidade veremos na sequência), conforme a exegese de Francisco 


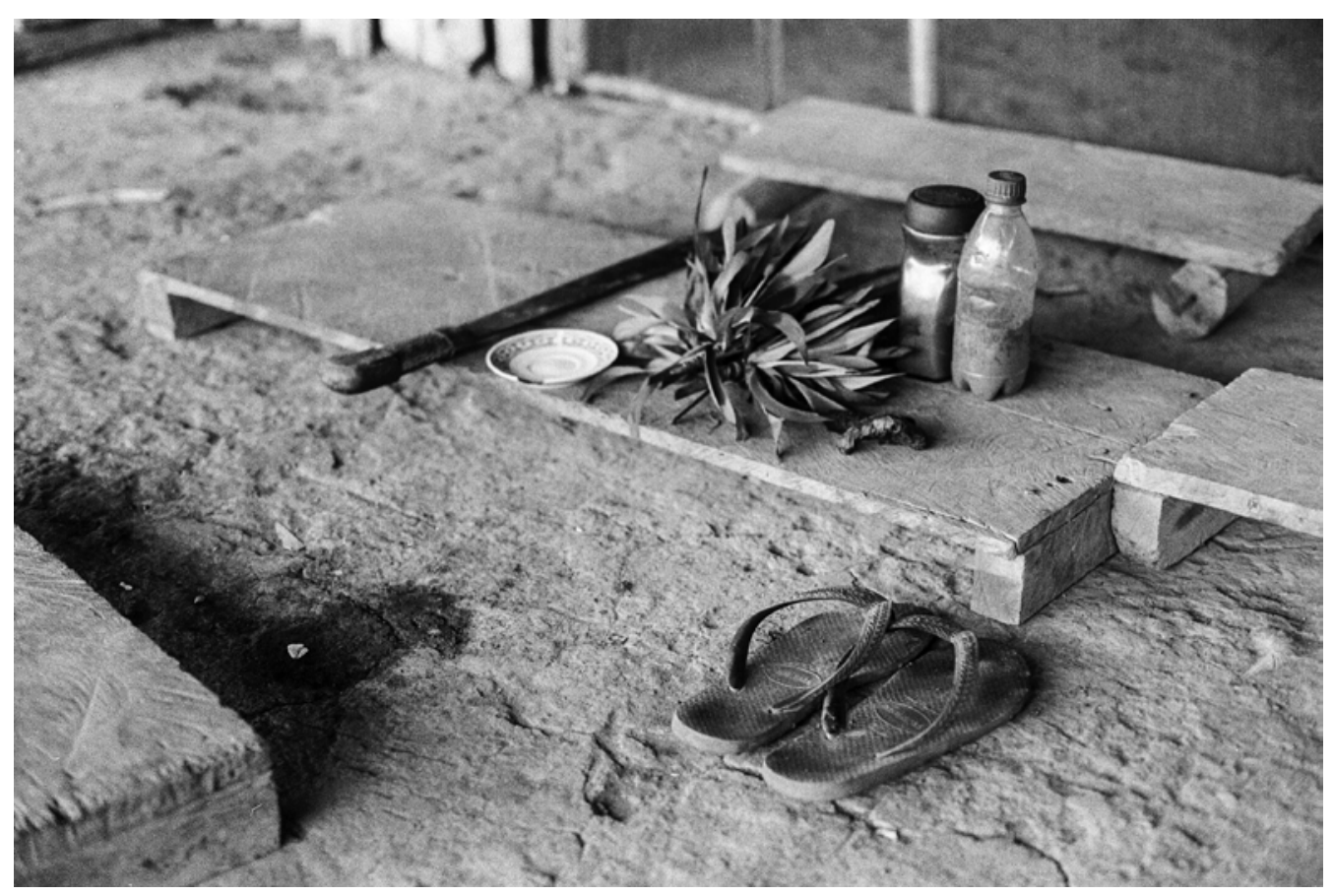

Fig. 68. Banquinhos (rotikëotima) com recipientes de paricá (epena) e paricá do mato (yakoa), braçadeiras com penas de papagaio, terçado e brejeira de tabaco. Preparativos para o hekuramou do pajé (hekura) Cândido, na frente da casa de Francisco, área chamada de hato nahi heha, "pátio da casa" (fotografia de Daniel Jabra, 2020). 
sobre essa mesma narrativa, cada um dos hekura que vêm junto de seus cantos vai progressivamente "enchendo" o peito-clareira do pajé. Cada um deles, assim, "têm a sua casa, tudo isso no peito, só que essa casa não é tirada daqui, é outra, de outros lugares, de vários lugares, como as montanhas". Dessa forma, o pajé que conduz a iniciação convoca os hekura desde suas casas-montanhas, segundo Francisco, para que o aprendiz possa, a partir de então, engajar-se com tais seres-imagem e "poder focar todas as montanhas, onde tem espírito mau, onde tem espírito bom, para ser convidado para andar junto".

A imagem mobilizada pelo verbo "focar" (m.q. "focalizar") na exegese de Francisco deriva do léxico na língua portuguesa relacionado à caça. Para caçar jacaré, por exemplo você deve focar o animal a noite com uma lanterna para que, com o animal acuado, possa então atacá-lo com uma lança. No entanto, nesse contexto, o termo se expande à experiência visionária dos hekura. Ampliando a semântica do termo em português através do uso intensivo do epena, os pajés podem constituir e acessar imagens de tais seres, de forma que, ao focalizá-los, podem (segundo a definição do verbo) "formar com nitidez (uma imagem real ou virtual) em qualquer superfície no espaço, mediante um sistema óptico". Nesse caso, entretanto, o sistema óptico, mais do que físico, é sobretudo xamânico e a distinção entre o real e o virtual torna-se, assim, equivocada e superável, já que através do hekuramou o virtual (potencialmente associado ao universo dos hekura) torna-se real (pela experiência concreta mediada pelo corpo e pela perspectiva do pajé-tornado-espírito) e vice-versa. Com esse acesso à perspectiva dos espíritos, permite-se que o pajé e os seres-imagem dialoguem e estabeleçam relações de aliança xamânica - possivelmente mobilizando as múltiplas agências de tais seres para proteção, cura ou ataque - e, como disse Francisco, faz com que o pajé convide e seja "convidado para andar junto".

Seguindo outra narrativa de Cândido (traduzida por Mauro) podemos nos aproximar ainda mais desse processo de identificação, aprendizado e transmissão de espíritos auxiliares, cantos e casas que atravessa e que constitui o taamayõu:

Os espíritos aparecem, você vai olhar e depois imitar o hekura. O pajé vai buscar e vai entregar os hekura. Como que eles aparecem? É como essa sua lanterna de cabeça [na noite em que gravei esse relato na casa de Cândido eu estava com uma lanterna dessas], eles aparecem como raios, eles aparecem como raio [...]. Quando 
o pajé te bater, ele vai dar o espírito para você. Quando ele dar o hekura vai doer muito, você vai sentir dor. Você vai sentir como um terçado rasgando o peito e o corpo, como faz para abrir um queixada. Quando o pajé dar o hekura você vai morrer. O hekura está te matando, por isso você vai cair morto no chão quando o pajé te dar o hekura, porque é muito pesado.

No momento em que Cândido narrava sobre essa chegada dolorosa (em seus próprios termos) dos hekura adentrando o corpo do "aluno", ele simulava com as mãos o movimento dos raios descendo pelo topo da minha cabeça e adentrando o meu corpo, como se o rasgasse com um corte longitudinal de cima à baixo, "como faz para abrir um queixada". A experiência de morte a que Cândido se refere, entretanto, é o modo pelo qual os Yanomami costumam descrever os efeitos do alucinógeno epena pelo verbo nomai,, "morrer". De outra maneira, essa experiência pode também ser referida como poremou, algo como "tornar-se fantasma" ou "agir como fantasma". Conforme Bruce Albert, tal associação se deve ao fato de que durante o estado de alteração de consciência provocado pelos alucinógenos (mas, também, pelo sonho, dor ou doença), a imagem essencial da pessoa (no uhutipi) é afetada e deslocada (é "morta"), de modo que o espectro pore ("fantasma") que compõe a pessoa (como vimos, trata-se do componente da pessoa que, após a morte, sobe aos céus rumo ao xapono dos mortos) "assume o comando psíquico em detrimento da consciência (pihi)" (Kopenawa; Albert, 2015, p. 615, nota 19), processo esse que poderia ser referido também como "tornar-se outro", "virar outro" ou "assumir valor de outro".

Retomando o relato de Cândido, nota-se também que a aparição, apresentação e introdução dos hekura, mediado pelo pajé "professor", além de dolorosa e "fatal" é também intensamente luminosa, como um raio ou uma lanterna:

Assim, quando você responder ao pajé, enquanto ele te ensina, vai aparecer um raio. Você vai olhar e quando o pajé pedir para responder, você responde, para poder encontrar o espírito. Conforme os raios vão caindo, vão aparecendo os espíritos, como o do passarinho hëtmi [espécie cujas penas azuis de suas costas são usadas pelos homens e sobretudo pelos pajés como brincos pendentes; cotinga-azul, Cotinga maynana]. Vão caindo os raios e vai clareando, vai ter muito raio, você vai ver os hekura como um raio. Você ouve o trovão, aí você fala o nome dele, do espírito do 
trovão, e ele vai aparecer como um raio. Você vai sentir o trovão bater, você vai sentir o trovão bater. O pajé vai te dar e vai trazer o raio, vai chegar aqui pelo topo da sua cabeça, bem claro. Aí o espírito vai olhar bem, vai chegar contigo e você vai ouvir o barulho se aproximando, aí outro barulho vai surgir no céu, é assim que funciona. Como vêm os espíritos? O pajé vai buscar e os espíritos vêm para cá, pelo caminho dos espíritos eles vem vindo. O pajé pega o espírito, traz e te dá: "tau!". Aí você responde, você tem que pedir mais espíritos para ele [para o "professor"], você tem que imitar outros. "Você não pode ser sovina", você diz a ele. Pede mais hekura, pede para trazer mais. "Como você é pajé grande tem que trazer mais, não pode sovinar". Aí ele vai ouvir e vai te trazer muitos hekura, vão aparecer muitos.

A chegada dos hekura, assim como comentamos no capítulo "Casa-aldeia" sobre as concepções em torno da luminosidade, se dá através da "luz como intensidade pura", "em sua maior potência" (Viveiros de Castro, 2006, p. 322), como um raio (xĩi). Retomando a leitura de Eduardo Viveiros de Castro, trata-se assim de uma concepção (partilhada também por outras semiologias xamânicas entre os povos indígenas amazônicos) na qual a luminosidade e o brilho intenso dos espíritos "indica o caráter supervisível destes seres, que são 'invisíveis' ao olho desarmado pela mesma razão que a luz o é - por ser a condição do visível" (2006, p. 332). A luminosidade própria dos hekura, da perspectiva desses, então, adentra também o corpo-clareira do pajé e, tal qual na construção de um xapono no solo da terra-floresta, se complementa ao esforço de limpeza do terreno. Conforme o relato de um pajé yanomam apresentado por Smiljanic, no início do taamayõu:

O neófito fraco e entorpecido pela yakoana [uma variante nãocultivada do epena, feito com a casca ao invés das sementes, e chamada no Marauiá de yakoa ou, em português regional, paricádo-mato; Virola elongata] jaz no chão inconsciente. Enquanto seu corpo permanece ali, seus componentes incorpóreos são levados pelos espíritos [...]. Tem então início a construção da casa onde deverão morar seus espíritos auxiliares. Estes chegam e limpam o corpo do neófito, fazendo ali uma grande clareira onde deverão ser fincados os esteios da nova casa. O corpo interior do neófito é retalhado pelas facas que os espíritos auxiliares portam, ele sangra e se enche de feridas. Após o processo de purificação, a casa dos espíritos auxiliares é construída. Os espíritos do sol descem 
e fixam-se no peito do neófito, tornando claro o caminho a ser percorrido pelos espíritos auxiliares. Este caminho é comparado a uma luz, ao arco-íris, a espelhos (1999, p. 111).

A mesma imagem do xapono intensamente iluminado como um "arco-íris", tal como dizia-me Cláudio, pajé do Pukima Cachoeira (filho de Cândido e iniciado também por ele), assim, replica-se também na dobra interna do corpo do pajé que, desde a perspectiva dos hekura, corresponde a uma clareira onde suas casas serão construídas. A limpeza, a claridade e a luminosidade, portanto, se mostram como atributos vitais para a presença dos hekura, com ecos diretos, como vimos, no próprio modo yanomami de habitar a terra-floresta.

Retomando o final do relato de Cândido, a chegada dos hekura ao corpo do pajé "aluno", além da dimensão intensamente luminosa, é acompanhada "pelo som dele", isto é, o canto (amoa) próprio à cada classe de espíritos auxiliares e suas respectivas casas:

A casa deles [dos hekura, referindo-se aos seres no porepi] é boa, elas ficam aqui no céu. O pajé traz para cá o espírito no porepi [serimagem dos espectros dos mortos ancestrais; um exemplo, dentre os muitos hekura que podem ser convocados pelo "professor", segundo Mauro], ele vai dizer o nome da casa do espírito no porepi e ele vai avisar a pessoa: "Vai vir a casa do no porepï". Quando o pajé trouxer a casa do no porepi você vai ouvir o som dele [segundo Mauro, um barulho metálico, “tein!”]. Os espíritos que o pajé trouxer vão chegar dançando, alegres, chegando no seu peito dançando, como crianças os espíritos vêm brincando. É assim que funciona. Daí você pensa, "vou me tornar pajé" e você diz ao pajé [o "professor]: "Assim mesmo, assim mesmo, pode trazer mais espíritos" [...]. Então, quando ele trazer a casa dos espíritos, as suas imagens vão aparecer igual aos Yanomami, dançando no meio do xapono.

Conforme Cândido, então, no processo do taamayõu, junto de cada um dos seres-imagem vêm, simultaneamente, sua casa e seu canto ("o som dele"). Mediados pelo pajé "professor", em diálogo com os seres que convoca, os hekura se apresentam ao "aluno" tal como os convidados que chegam a uma grande festa na casa-aldeia: "igual aos Yanomami, dançando no meio do xapono". Assim, o corpo-clareira do "aluno", da perspectiva dos hekura, se apresenta como uma casa, na qual os seus espíritos auxiliares, durante as práticas do hekuramou que este deverá se engajar regularmente, são convidados a visitar, reproduzindo de forma prototípica a dança de 
Fig. 69. "Quando um Yanomami tornase xamã é assim que os espíritos descem até ele. Os xapiripë descem de muito longe, não vêm de perto. Por isso ainda que falem sobre suas terras, nós - não xamãs - não entendemos muito bem suas palavras" (framari Yanomami; Machado, 2014, p. 28). Desenho de Joseca Mokahesi Poroaunahiki thëri Yanomami (2014).

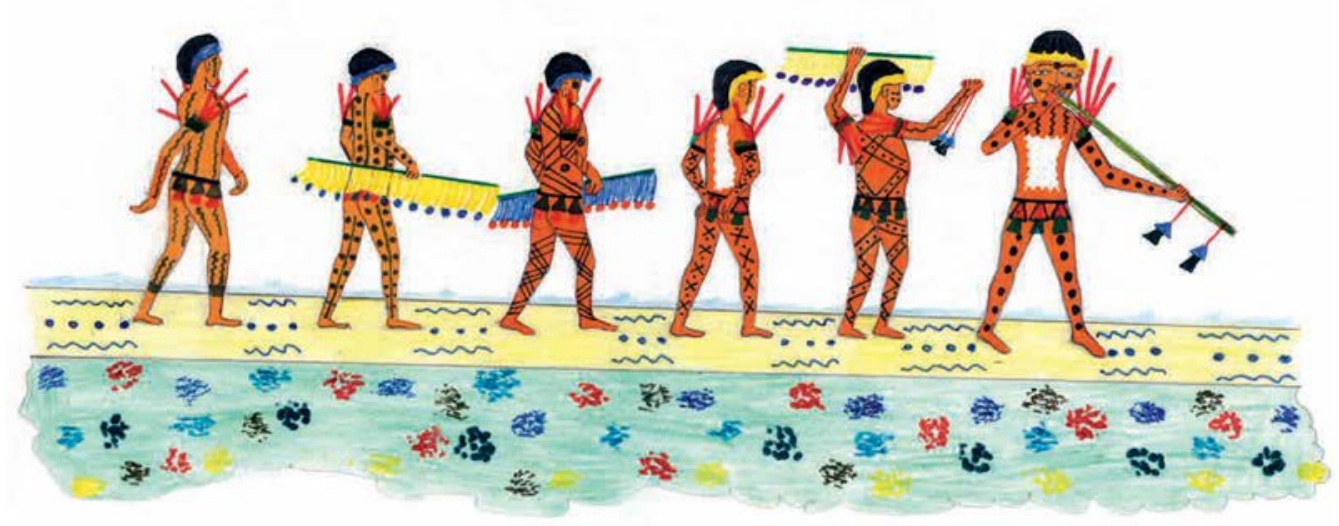


apresentação praiai tal qual nas aberturas das festas intercomunitárias reahu.

A simultaneidade entre a casa e o canto dos hekura, contudo, pode ser talvez melhor aprendida nessa outra narrativa de Cândido (traduzida por Francisco):

[...] Ao mesmo tempo, o pajé vai pegar as outras casas dos espíritos. Ao pegar uma casa, já vem o canto, o amoa do espírito, para ele [o "aluno"] poder gravar o canto do espírito. Daí vem outra casa com as músicas, os cantos dos espíritos, e o pajé dá o canto do espírito bem perto da boca dele para ele segurar bem o canto. Ao mesmo tempo, já começou o canto, com um monte de casas vindo para o peito. E o pajé vai dizer a ele: "Meu filho, os espíritos querem ficar no seu peito mesmo, os espíritos estão gostando de você, cheire paricá para eles ficarem felizes!”. Aí vem outra casa, outro canto. O pajé vai buscar outras casas, levando seu canto, e assim que o aluno levanta, o pajé fala outro nome da casa do espírito, até derrubar o aluno. Quando o aluno recebe bem os espíritos, quando vem o hekura como se fosse um raio forte, ele é partido no meio e cai no chão. $O$ aluno vai ouvindo o barulho - "tchuun!" -, um som como se fosse partido no meio, vai doer. Assim que o pajé faz. Assim que o pajé me fez [aqui Cândido refere-se à iniciação que ele próprio passou, conduzida pelo seu finado sogro].

Conforme me esclarecia Francisco, após a gravação desse relato, os cantos dos hekura são enunciados e, assim, ensinados ao "aluno" de forma simultânea à introdução em seu próprio corpo das casas relacionadas a cada um dos espíritos auxiliares - imagem que aproxima, assim, o corpo do pajé não a uma só casa, mas a um xapono, um corpo-casa-aldeia. Segundo essa exegese de Francisco, o nome de um hekura (ou de uma classe de hekura que não se limita a um, mas a uma multiplicidade implícita) corresponde ao nome de seu canto e também de sua casa. Assim, quando o pajé transmite um canto ao "aluno", nomeando-o e ensinando-lhe - "bem perto da boca dele para ele segurar bem o canto" -, simultaneamente, lhe transmite também uma casa, a morada de um certo espírito auxiliar.

Assim, se o pajé é aquele capaz de "abrigar um hekura no peito" përimapou, verbo transitivo a partir da raiz verbal përi-, como vimos em "Tapiri", cuja extensão semântica inclui também o sentido de "hospedar alguém" ou de "guardar um objeto perto de si na sua rede" (Lizot, 2004, p. 307) - , da perspectiva dos hekura, o corpo do pajé é aquilo que para 
si mesmos eles entendem como as suas próprias casas. Retomando a fala de Cândido:

Os espíritos que o pajé trouxer vão chegar dançando, alegres, chegando no seu peito dançando, como crianças os espíritos vêm brincando. É assim que funciona. [...] Então, quando ele trazer a casa dos espíritos, as suas imagens vão aparecer igual aos Yanomami, dançando no meio do xapono.

"No seu peito dançando", os hekura têm para si o corpo do pajé como um xapono ("casa-aldeia"), assim como para nós é um xapono esses lugares da terra-floresta que habitamos, também, "dançando no meio do xapono". Assim, no processo do taamayõu, a "casa de espíritos" (hekura pë yahipì) é transmitida de forma ubíqua. O que para nós (não-pajés) se apresenta como indícios em forma de cantos transmitidos ao pajé que se inicia, para os pajés e espíritos hekura, tal processo corresponde à versão hiperluminosa da dança de apresentação pratait, que adentra a espacialidade virtual do corpo do xamã "morto" pelo epena. Desta perspectiva, cada hekura com seu respectivo canto adentra o peito-clareira do pajé tal como um xapono animado pela festa, pela dança e pela cantoria. No interior do corpo-xapono, espaço reversível pela experiência e pela iniciação xamânica a qual o pajé se submete, os hekura são assim capazes de com ele produzir parentesco, produzir aliança e, enfim, construir suas casas em seu peito-clareira.

A mesma composição ubíqua, reflexo da corporalidade intensiva e recursiva dos pajés, se apresenta, por exemplo, noutro termo em yanomami para "pajé", xapori. A palavra corresponde à "pajé", no geral, mas também aos espíritos convocados como aliados e que habitam o corpo do pajé, diferentemente de hekura que, em certos contextos, referese especificamente aos seres-imagem livres e selvagens que vivem nos penhascos rochosos. Xapori e xapono, inclusive, partilham de uma mesma raiz em comum que, como aponta Lizot, "se refere ao seu caráter de domesticidade" (2011, p. 151). Como vemos no processo do taamayõu, portanto, trata-se de uma domesticidade recursiva e assim marcada pela ubiquidade em que ambas as perspectivas (do pajé em iniciação e dos hekura em festa, digamos) decorrem simultaneamente, mas em duas referências distintas: o corpo, da perspectiva humana e a "casa de espíritos", da perspectiva extra-humana. Como sugere Cesarino - falando sobre os pajés romeya marubo, cuja pessoa é também marcada pela ubiquidade do corpo-maloca -, embora o processo seja referido como decorrendo 
internamente ao corpo, com os hekura adentrando-o e lá construindo suas casas, esse processo talvez seja melhor compreendido como uma construção complexa e recursiva. Nesse sentido, o corpo-casa do pajé é "menos um espaço dentro do outro (ou, pior ainda, um espaço imaginário interno), mas um espaço a partir do outro" (2011, p. 138). Nesse sentido, ambas referências (ambos espaços ou ambos mundos) existem e decorrem paralelamente, embora visível somente aos pajés e espíritos hekura. Como diz Smiljanic sobre os pajés e espíritos (xapiri) yanomam: "Cada um destes mundos [...] são microcosmos que existem simultaneamente e pelos quais os pajés transitam livremente" (1999, p. 51).

A sequência do taamayõu é permeada então por essas duas referências paralelas (e transponíveis pelos pajés) que acompanham todo o processo de "construção conceitual" (Hugh-Jones, C., 1979, p. 235) da "casa de espíritos" (hekura pë yahipì). O final desse processo de construção e também de iniciação xamânica, no entanto, complexifica ainda mais a construção recursiva própria da ubiquidade do taamayõu. Assim, no último dia da iniciação-construção uma outra morada é trazida para o peito do pajé, morada essa que poderíamos pensar como a "casa de espíritos da casa de espíritos" ou a "casa-montanha do corpo-casa-aldeia". Sobre essa etapa, voltemos ao relato de Cândido (traduzido por Francisco):

Para ser pajé mesmo tem que prestar atenção para ver se ele [o "professor"] está dando mesmo os espíritos [...], [com isso, o "professor"] olha se o peito encheu mesmo [de "casas"] e vai mandar cortar um pau para a casa dos espíritos. Três rapazes vão tirar esse pau [chamado de pei maki, assim como as montanhas e picos rochosos], pintar com urucum, pena branca de gavião, papagaio. Essa é a casa dos espíritos. Nesse pei maki vai vir trariwë [ira, "onça-pintada", Panthera onca] e Yaoriwë [yao, "onça pequena", segundo os Yanomami, espécie não-identificada, talvez "jaguatirica", Leopardus pardalis, ou "gato-maracajá", Leopardus wiedii]. Eles são os cachorros da casa, para proteger a casa, para não chegar perto da casa dos outros espíritos. Dando isso o aluno vai perceber como se fosse onça de verdade [isto é, o animal, ira] e vai doer como arranhões de onça. Daí vai ser levantado de novo e o pajé vai passar nele uma taboca [hõrõmato, "tubo com o qual os hekura projetam substâncias mágicas"; cf. Lizot, 2004, p. 109] e chamar o espírito Hõrõmato, soprando no corpo do aluno. E quando ele estiver deitado, esse espírito organiza o aluno que o frariwë deixou bagunçado. Por dentro, ele ventila os 
Fig. 70. łrariwë, ser-imagem Onça, protetor da casa de espíritos. Desenho de Joseca Mokahesi Poroaunahiki thëri Yanomami (2003).

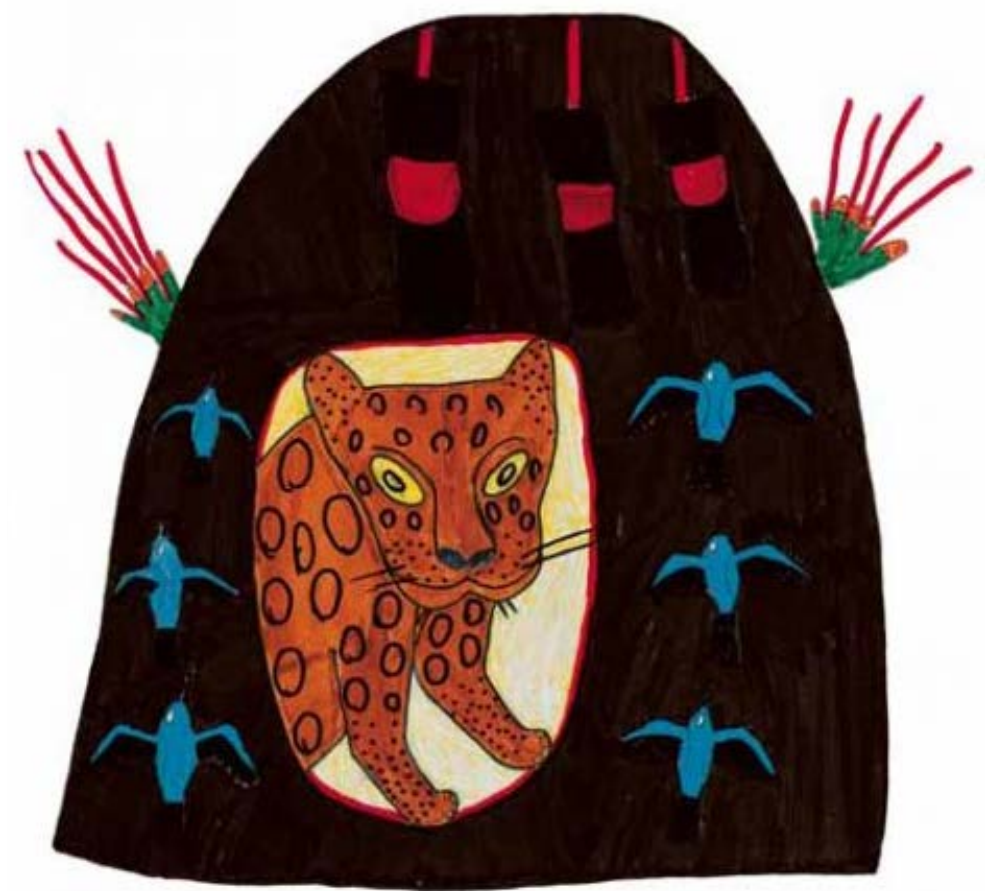


ossos para ele ressuscitar de novo ["como um ar-condicionado ou ventilador", explica-me Francisco]. Terminando isso, depois de frariwë, eles vão pegar a casa do espírito, pei maki. Vão pegar machado, terçado, flecha e vão trazer a casa dos espíritos [nesse momento, com o pau fincado no chão do meio do xapono, no extremo oposto da casa em que se dá taamayõu]. Tem que tirar todas as raízes do pei makí, sem quebrar as raízes. Têm que ser bem cortadas para não dar problema com o rapaz que está sendo iniciado. Quem vai trazer o pei maki é Morõriwë [morõ, "taturabo-de-couro", Cabassous unicinctus] e Wakariwë [waka, "tatucanastra", Pridontes maximus]. Morõriwë fica embaixo, Wakariwë em cima e os Paxoriwë [paxo, "macaco-aranha", Ateles] pegam no meio para não cair a montanha, fazendo como se fosse um gancho ou uma forquilha com as mãos. Daí dois rapazes seguram o jovem e o pei maki é colocado no meio da cabeça dele para poder entrar toda a raiz. Mesmo os dois rapazes segurando ele, ele vai ser prensado, por causa do peso da pedra. Fazendo isso outro espírito que se chama Porehimi ["espírito que fica no olho e supervisiona se está dando certo, para ver se está retinho", segundo Francisco]. É assim. Assim que eu aprendi, assim que eu estou falando. [No dia seguinte, no último dia] tira de novo a casa do espírito e vem o Warëriwë [warë, "queixada", Tayassu pecari]. De manhã, vai ser jogada a água sobre o fogo, fica lama, e o rapaz é jogado na lama com cinzas, como queixada, com cheiro de queixada mesmo, e no mesmo tempo pode dar comida, banana, taioba, pupunha [e com isso, gradualmente, o "aluno" pode voltar a se alimentar normalmente]. E daí vai vir também o Xokoriwë [xoko, "tamanduá-mirim", Tamandua tetradactyla], Ihamariwë [ihama, "bicho-preguiça", Bradypus tridactylus], Paxoriwë [...].

Pei maki, como notado anteriormente, indica os penhascos rochosos - as casas-montanha onde habitam os seres hekura - e, simultaneamente, o pau adornado utilizado durante os últimos dias do taamayõu - ele próprio concebido como "montanha" e "casa de espíritos" dos hekura. Dessa maneira, a mesma ubiquidade que marca o processo do taamayõu com a transmissão de conhecimentos xamânicos através das casas-cantos aqui se faz presente através do pau-casa-montanha. Segundo Francisco, normalmente se utiliza a madeira da árvore mõrã mahi (Dacryodes sp.) para fazer a estaca que, com a ponta mais fina voltada para baixo, constitui-se na base que será posteriormente adornada. No entanto, 
variam não só as madeiras utilizadas como também o modo de adornar o pei maki. Certa vez, por exemplo, acompanhei o taamayõu de um pajé já experiente do Manakapiwëi que havia ido ao no Pukima Cachoeira para ser "iniciado" com Cândido e Nelson, reconhecidos pajés desse xapono "intercâmbios" esses que são valorizados pelos hekura a fim de multiplicar seus cantos-casas a partir de outros conhecedores aliados. Segundo alguns interlocutores do Pukima Cachoeira, como o "aluno" e pajé visitante "já sabe cheirar paricá" - algo que mencionavam como se estivesse a fazer uma especialização ou uma pós-graduação, "para virar doutor" - ele não precisava de um pei maki "de verdade" e utilizava, ao invés de uma estaca de madeira, uma flecha com a ponta voltada para baixo para ser fincada na terra. A flecha era adornada tal como uma estaca de madeira, embora de forma mais discreta. Normalmente, tais adornos consistem em uma pintura com urucum, dando-lhe uma base vermelha e, por cima, linhas sinuosas e pontos intercalados desenhadas com uma variante mais escura dessa tintura. Sobre a pintura, o pei makie é emplumado com penas brancas de gavião ou, por vezes, com algodão, às vezes praticamente ocultando a pintura abaixo. E no topo é então adornada com penas de papagaio e penas de penas do rabo da arara-vermelha, tal como as braçadeiras comumente utilizada pelos pajés.

Esse artefato ou, melhor, essa casa-montanha, poderia assim ser pensada como um "modelo reduzido" (Lévi-Strauss, 2012), no sentido de um objeto (de uso ritual, digamos) que permite um modo de agir sobre o mundo através de um elemento que condensa e que transpõe a montanha (da perspectiva dos hekura, a casa de espíritos) da terra-floresta para o peito do pajé durante o taamayõu. O pei makí, seguindo a lógica do modelo reduzido, compartilha de certas propriedades estéticas e sensíveis das montanhas e dos picos rochosos, mas em escala reduzida. Dentre estas, a verticalidade, como um mastro fincado na terra ou ponteado na cabeça ou entre as pernas do "aluno"; a beleza e o brilho, decorrente dos adornos e dos grafismos; e o peso e a dureza que, se não estão necessariamente presentes na constituição da madeira utilizada, são notáveis nos relatos e também nos gestos corporais dos pajés que o carregam e o manipulam durante a iniciação xamânica. No entanto, a redução de escala, no sentido das dimensões físicas do objeto (da montanha ao pau, nesse caso) não é exclusivamente o que constitui um modelo reduzido. Para Lévi-Strauss, a redução deve ser entendida para além da escala e, de um ponto de vista 
complementar, sugiro que a noção de escala seja também compreendida para além de um sentido mais imediato de ordem dimensional, a partir da ideia de que "a transposição gráfica ou plástica implica sempre uma renúncia a certas dimensões do objeto" (2012, p. 40). A "renúncia a certas dimensões" de que fala Lévi-Strauss vai além da grandeza física e abre campo para pensarmos, então, a noção de escala em um sentido ampliado, estendendo-a para outras propriedades do objeto e transfigurando a operação de redução à outras noções que, nesse caso, me parecem mais pertinentes e produtivas, como a replicação e a variação posicional e escalar.

A variação posicional e escalar do pei maki que, a depender da perspectiva, pode ser visto como montanha, casa, corpo, pau ou pedra, talvez se faça mais explícita na explicação que ouvi do interlocutor Mauricio Iximawëteri (em português) sobre os sentidos do pei maki:

Você vê as montanhas altas, é a mesma coisa, as montanhas e as casas dos espíritos. Os espíritos moram dentro das montanhas. Eles fazem como nós fazemos. Eles vivem como nós: usam fogo, caçam, tem roça. [...] A casa no peito é a montanha quando está terminando de ensinar o hekura. Eles tiram a casa deles e fazem o pei maki. O pei maki é a casa. O pau tira no mato e é como se fosse a montanha que está lá. Dizem que o pau parece a serra mesmo. Quando coloca o pei maki na cabeça é como colocar a montanha no peito da pessoa, o pau é a raiz da montanha e vara o corpo. Depois os hekura distribuem a raiz da montanha para a montanha não cair. A raiz da montanha entra dentro da pessoa e a serra fica dentro da pessoa. Depois os espíritos ganham o espaço para morarem nessa montanha, a casa deles. [...] A casa é uma montanha. Dizem que parece uma montanha. Mas só a vê quem ensina e quem é ensinado. [...] A montanha fica sempre no corpo. É de pedra, igual à serra do mato. Pedra, pedra mesmo.

Além disso, através de tal ubiquidade - em suma, entre pau e pedra ressalta-se também a dimensão imperecível (ao menos durante o tempo de vida do pajé, como vimos acima) de tais casas de espíritos construídas no - ou a partir do - corpo do pajé. "De pedra, igual a serra", como diz Mauricio. Mas também, como relatam outros interlocutores, como Nelson, pajé do Pukima Cachoeira, que diz que ao dormir sente "o peito pesado, como se estivesse cheio de areia", referindo-se assim à sua própria casacorpo. Segundo ele (traduzido pelo seu filho Ricardo), sua casa de espíritos é "como o xapono aqui, grande, mas de pedra; não estraga nunca, muito duro, como as montanhas". A mesma comparação com o xapono "daqui" 


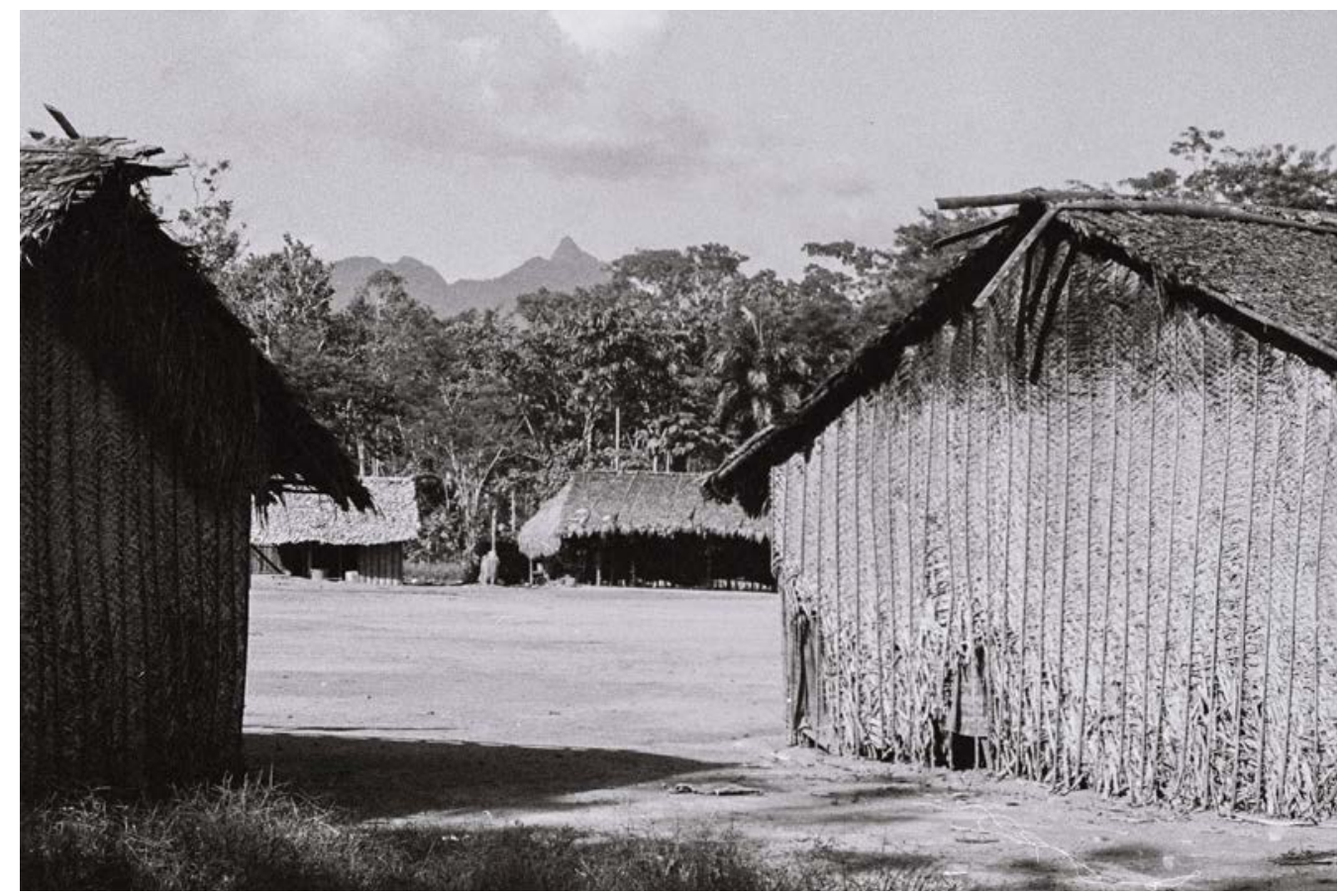

Fig. 71. Pukima Cachoeira visto do caminho que conecta o xapono à beira do Rio Marauiá. Entre as casas, aos fundos, a serra e os picos rochosos (pei maki), "casa de espíritos” (fotografia de Daniel Jabra, 2019). 


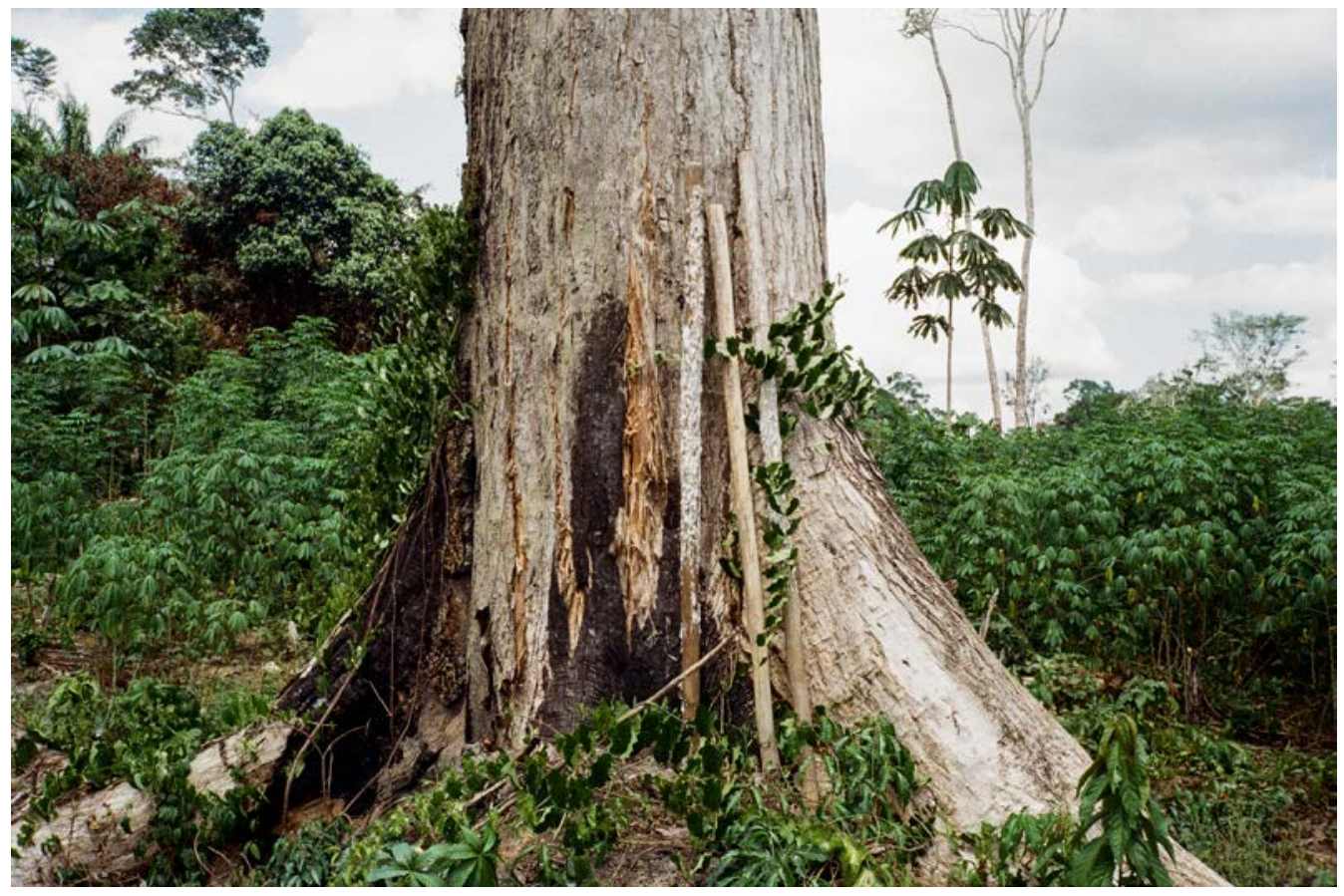

Fig. 72. Três pei maki com os adornos envelhecidos, encostados sobre um grande ipê (tomoro) em uma roça. Cada um deles corresponde a uma iniciação xamânica (taamayõu) de um pajé do xapono Pukima Beira (2019). 


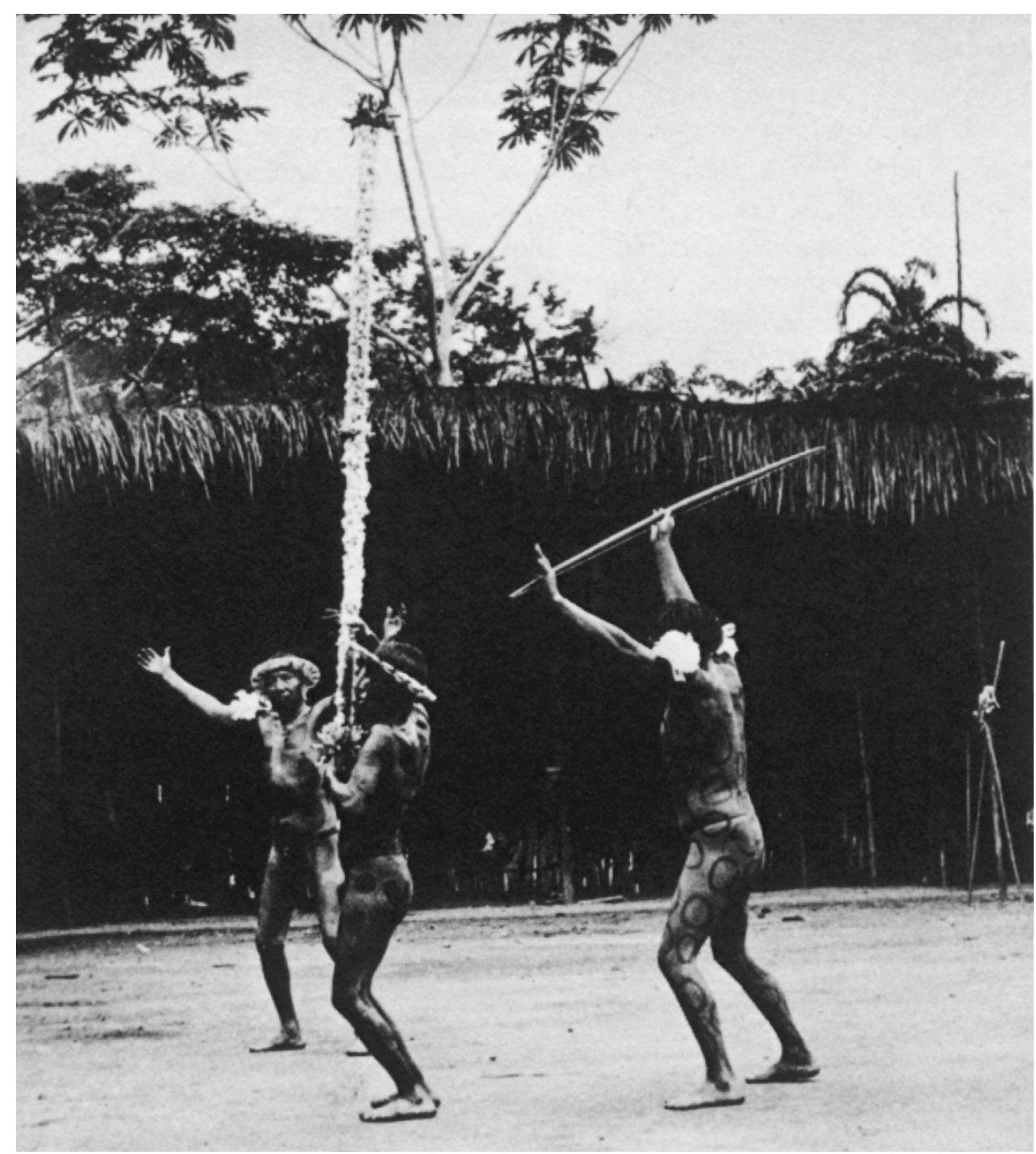

Fig. 73/74. Uma das restrições em torno das imagens estabelecida pelos meus interlocutores é em torno do registro dos pajés durante as sessões de pajelança (hekuramou) e de iniciação xamânica (taamayõu). As fotografias, segundo eles, poderiam captar sua imagem e, com isso, colocá-lo em risco. Reproduzo aqui, a fim de auxiliar na leitura do processo de iniciação xamânica, duas fotos de Jacques Lizot (1998), provavelmente da década de 1970 , em que se vê o pei makí, "casa-montanha" dos espíritos hekura, sendo carregado através do meio do xapono e, na página seguinte, fincado nas pernas do "aluno". 


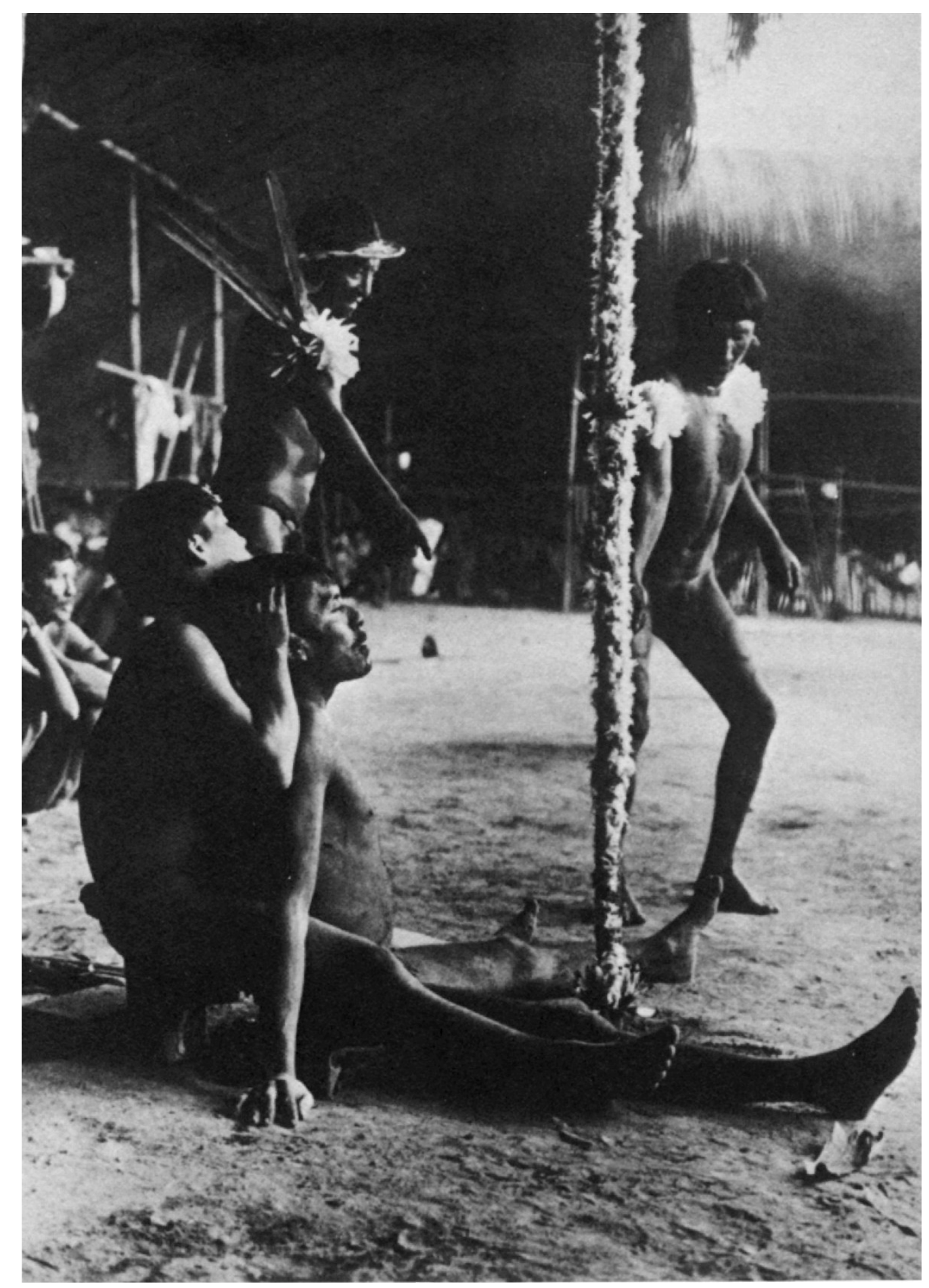


foi feita também por outro interlocutor do Pukima Beira, Emerson, assinalando, de forma complementar à escala grandiosa, também a limpeza exemplar, ambas de dimensões intensivas e extra-humanas. Dizia ele que a casa de espíritos e os xapono dos pajés (hekura) são "do mesmo formato", mas "muito mais limpo e mais organizado" e, além disso, "muito mais alto, como um hotel" - e, com isso, provavelmente referia-se a um dos hotéis da cidade de Santa Isabel do Rio Negro, um dos poucos edifícios com mais de dois pavimentos da cidade. O próprio Maurício, no mesmo contexto da fala acima citada, também relacionava as casas de espíritos com os edifícios urbanos, dizendo que estas são "como na cidade", feitas "de metal", "como prédios, de tão grande". Claudio, pajé do Pukima Cachoeira, ressalta a mesma coisa, e diz que as casas de espíritos são "altas" e, referindo-se especificamente à casa-corpo de Cândido, está então é "muito alta!".

A dureza, a altura e o peso da casa-montanha (pei maki) são também aspectos ressaltados na fala de Cândido apresentada acima sobre o taamayõu, assim como na exegese que Francisco realizou na sequência, a fim de me esclarecer alguns pontos da narrativa. Segundo ele, são sempre os seres-imagem Morõriwë (Tatu-rabo-de-couro) e Wakariwë (Tatu-canastra), junto do auxílio dos seres Paxoriwë (Macaco-aranha), que são os responsáveis por carregar o pei maki: "mesmo que pesado, eles que trazem, e os outros [Paxoriwë] vão segurando em cima, para não cair, para não entornar, para ser bem reto, para não cair as montanhas". E conforme Ricardo, do Pukima Cachoeira, são estes os "que constroem o pei maki no peito do pajé, eles que carregam os paus, um na frente e outro atrás, mas não é um pau como esses, é muito duro mesmo, é pedra, igual as serras". Como nota-se ainda na narrativa de Cândido, é com a introdução do pei maki, nos últimos dias do taamayõu, que o aluno se torna apto a receber outros hekura que não aqueles primeiros (como os seres-imagens da plantas, como vimos) que, preliminarmente, preparam e limpam seu corpo-clareira, fazendo também suas primeiras casas. A partir desse momento ele passa a receber, mediado pelo pajé "professor", os hekura considerados como mais fortes e mais potentes, tal é o caso do próprio Wakariwë - o "carregador" da casa, como me disse Mauricio - hekura reconhecido pela sua força extrema, já que com seus braços e garras pode destroçar os seres maléficos relacionados às doenças que ameaçam as pessoas. Ainda segundo Francisco, é com a chegada do 
pei maki, em seus termos, "que vão ficar todos, assim, morando nessa casa; vai ser como se cada um tivesse um quarto, cada um na sua rede, em umas fileiras". Reunidos assim em no interior de tal casa-montanha, "os espíritos vão conversar e ver se o pajé vai ser bom mesmo, se é bem cuidado mesmo, se ele quer ser pajé mesmo, aí eles vão ficar". Com o tempo, no entanto, outros hekura podem adentrar e povoar ainda mais tal morada, que, segundo Francisco, assim vai "enchendo, enchendo, abrindo mais espaço"; vai "aumentando, aumentando, aumentando, até acabar a vida, aí o espírito vai embora [...] e depois tem que refazer de novo, ensinar outro de novo".

É nessa grande casa-montanha - um "malocão", segundo Francisco - onde habitam os hekura mais poderosos que protegem o corpo-casa do pajé, notadamente łrariwë (Onça) e Yaoriwë ("Onçinha"), tal como, de outra perspectiva, é o pajé que protege o xapono em que habita (lembrando da fala de Adriano mencionada no capítulo "Casa-aldeia"). Como ressalta Cândido através de metáfora dos cachorros que, no próprio xapono, por exemplo, têm a função essencial de afastar possíveis invasores humanos ou extra-humanos, tais hekura "são os cachorros da casa, para proteger a casa, para não chegar perto da casa dos outros espíritos". Francisco, nesse contexto, assim me explica que são trariwë e Yaoriwë que "protegem a casa do dono", isto é, seu corpo ou corpo-casa: "Os espíritos são donos. Assim como esse cachorro, quem é dono é minha mãe e meu pai. Essa Onça [łrariwë] é para não chegar alguém nessa casa. Ela protege. A Onça protege a casa. Assim como nas montanhas é onde tem a maior onça [ira]". E nesse mesmo sentido, Mauricio dizia-me que trariwë é o hekura que "ajuda o pajé doente" e "defende do mal", já que é capaz de "segurar a vida dessa pessoa" e assim, portanto, capaz de proteger o corpo do pajé que, da sua perspectiva, passa a ser sua morada.

Com o fim do processo de iniciação, o pei maki é enfim encostado no tronco de uma grande árvore da floresta ou das roças ao redor do xapono. Certa vez, por exemplo, caminhando em uma roça do Pukima Beira, notei três paus com as penas e plumas de gavião já muito deterioradas pelo tempo, encostado numa grande árvore, intocada no meio da mata queimada pela coivara. Como me disse Eric, interlocutor que caminhava junto, os paus correspondiam às três etapas da iniciação xamânica que o pajé Arlindo havia recém passado naquele mesmo xapono. E, após esse procedimento, os paus deveriam justamente serem devolvidos à floresta e encostados numa 
árvore como essa, tomoro (ipê, Tabebuia guayacan), de madeira "dura como rocha" e também ela considerada como "casa de hekura".

Ao fim, o imperecível das rochas ou mesmo das grandes árvores não é totalmente impassível à perturbação alheia. E se por um lado são os pajés que tornados eles próprios casas-montanha são capazes de se aliarem aos seres-imagem potencialmente perigosos como frariwë, por outro lado são estes mesmos hekura (pajés e espíritos) que, frente à sanha destrutiva dos napë (os "brancos"), ficam furiosos com isso. Retomando o que disse Adriano (apresentado no capítulo "Terra-floresta"):

As montanhas são casas de pajés [espíritos hekura] perigosos. Se [vocês, os napë] continuarem destruindo tudo [...] os pajés vão ficar muito bravos e vão cortar o céu. Eles sabem onde estão os buracos, eles sabem cortar o céu, e se isso acontecer, esse céu vai cair, assim como esse aqui [apontando para o chão, para a terra] que já caiu antigamente [...] e quando aquele céu cair todos vão morrer [...] Os napë não sabem disso, eles não veem, eles só veem dinheiro. Os carros, os barcos, tudo isso tem espírito, é Siparariwë. Ele destrói as coisas mais duras. Se vocês continuarem destruindo tudo, é isso que vai acontecer. São os pajés que seguram o céu e não deixam os outros pajés [espíritos hekura] de lá cortarem, mas se vocês continuarem destruindo tudo os pajés vão ficar muito bravos e o céu vai cair. 
Assim é

Essa saudade sempre vai estar no nosso coração para onde a gente for. Ela abre no fim do dia, no entardecer, e no sonho.

Adriano Pukimapiwëteri Yanomami (2020)

"O que tanto você anota nesse papel?", perguntavam meus amigos e interlocutores yanomami em diferentes momentos em que estivemos juntos. Difícil pergunta que talvez somente agora eu tenha a resposta. Ao fim, esse texto é uma tentativa de pensar com (o que eu chamei de) "o jeito de pendurar redes". Inclusive, sempre achei curioso que, de certa forma, pendurado em minha rede, eu habitava o interior do corpo do meu objeto de pesquisa. Pensando agora, talvez parte desse tal objeto também habite dentro de mim. E com a tentativa de tornar isso compreensível, escrevo. Isso é parte dos termos de nossa relação de aliança. Faço isso a partir de descrições etnográficas estimuladas pelas arquiteturas do morar construídas, de diferentes maneiras, pelos Yanomami, povo com quem tive a alegria de conviver e de aprender junto. Alegria, como evoca Isabelle Stengers, cuja potência é capaz de modificar as "relações entre as dimensões já habitadas"; "alegria de pensar e de imaginar juntos, com os outros, graças aos outros" (2015, p. 152).

Da Lua ao Brasil, da construção à queima, da agregação à desagregação, do perecível ao imperecível, o que ressalto ao longo dessas linhas é o caráter mítico das arquiteturas yanomami que, como diria Claude Lévi-Strauss, "não terão afinal feito, como um vasto sistema mitológico, nada além de exibir os recursos de sua combinatória, antes de involuirem e se aniquilarem na evidência de sua decadência" (2011, p. 669). A evidência da decadência, entretanto, talvez tenha sido dos aprendizados de maior valor ao longo desses anos de convivência com o "povo da terrafloresta" ou, como diria Ailton Krenak, esse povo "como a folha que cai" (1994, p. 203). Durante minha última e longa viagem de barco descendo o Rio Marauiá em fevereiro de 2020, pouco antes de tomar conhecimento da pandemia que se aproximava e, por outro lado, completamente tomado pela intensidade do sol sobre a minha cabeça, enfim entendi que é justo 
esse modo transitório e inconstante das formas de "pendurar redes" que fazem do perecível, imperecível. Quero dizer, é pisando leve sobre a terrafloresta que a continuidade desse modo de viver e de habitar se estende, com toda vivacidade e resistência, desde os tempos do sangue da Lua. Contra a "religião da civilização" e aqueles que "mudam de repertório, mas repetem a dança" do "pisar duro sobre a Terra", aprendi com o povo da terra-floresta, ao contrário, sobre o "pisar leve, bem leve, sobre a Terra" (Krenak, 2019), como "um voo de um pássaro no céu" no qual em "um instante depois que ele passou, não tem rastro nenhum" (Krenak, 2020).

A leveza implicada nessa outra forma de habitar e construir, contudo, não deve ser pensada na chave tecnocêntrica da inferioridade técnica, mas, pelo contrário, a partir do interior de seus próprios critérios e concepções - objetivo último desse trabalho, portanto. Dentre essas concepções, por exemplo, situa-se o uso de materiais da floresta - um tapiri (yãno), uma casa (yahi) ou um xapono, afinal, não é mais do que a continuação da floresta por outros meios, tornada habitável deliberadamente feitos para desmanchar, isto é, para não deixar rastros. Como uma rede, que flutua sobre o solo e não deixa pegadas, caminha de um lugar para outro e é queimada junto de seu corpo no momento de sua morte. Assim, diferente de "nosso mundo e seu insano projeto cartesiano cujas consequências ecológicas mal começamos a medir" (Clastres, 2003, p. 203), "o jeito de pendurar redes", com as variadas técnicas do "viver junto", é marcadamente contra qualquer "excesso inútil", contra o acúmulo privado de bens ou o desejo de posse e, portanto, contra o "desejo de poder" (Clastres, 2003, p. 208/217). Não a manutenção da matéria, mas a manutenção do bem viver, permeada pelos conflitos da convivência, da consanguinidade e da aliança que, ao fim, gera o equilíbrio parcial e necessário entre o viver junto e seu revés, ao mesmo tempo em que, das duas formas, renovam-se o ciclos que fazem do "jeito de pendurar redes" se não algo parimi ("eterno"), algo vivo e contínuo.

O esforço dessa etnografia, então, foi o de procurar uma maneira de formular não uma "teoria da arquitetura yanomami" (ou "indígena") algo que, de fato, os próprios não precisam e, se quiserem, o farão à sua maneira - mas aquilo que um antropólogo napë ("branco") pode precisar formular como uma teoria para descrever tais modos de construir e habitar. Inspirado pelas linhas conclusivas de Marylin Strathern em Learning to see in Melanesia, eu poderia dizer que o que estou atribuindo ao "jeito 
yanomami de pendurar redes" é apenas "parte de um esforço para fazer com que eu - nós mesmos - 'enxerguemos' de maneira diferente" (2013b, p. 145). Assim, o mundo construído nessa pele de papel não é o mundo que os yanomami vêem - tais práticas de "pendurr redes", afinal, como diria Strathern, "não se preocupam em descrever 'um mundo"' (2013b, p. 145). Ao contrário, "sem tal construção 'nosso' mundo (com o qual nos preocupamos) será tudo o que 'nós' vemos" (Strathern, 2013b, p. 145). Contra o mundo-de-um-mundo-só e contra os olhos que só enxergam dinheiro, como bem disse Adriano Pukimapiwëteri, escrevo. Os papéis, como as casas e os corpos, bem sabemos, queimam como a madeira. Mas, afinal, que possamos aprender ao menos com uma centelha de brilho breve - isto o que esse trabalho talvez seja, uma brasa ao léu -, como um vislumbre, um transe ou um sonho. E, assim, como disse Donna Haraway (2020), que possamos seguir nos aliando com mundos que importam e que façam sentido. Esse é o meu pensamento. 


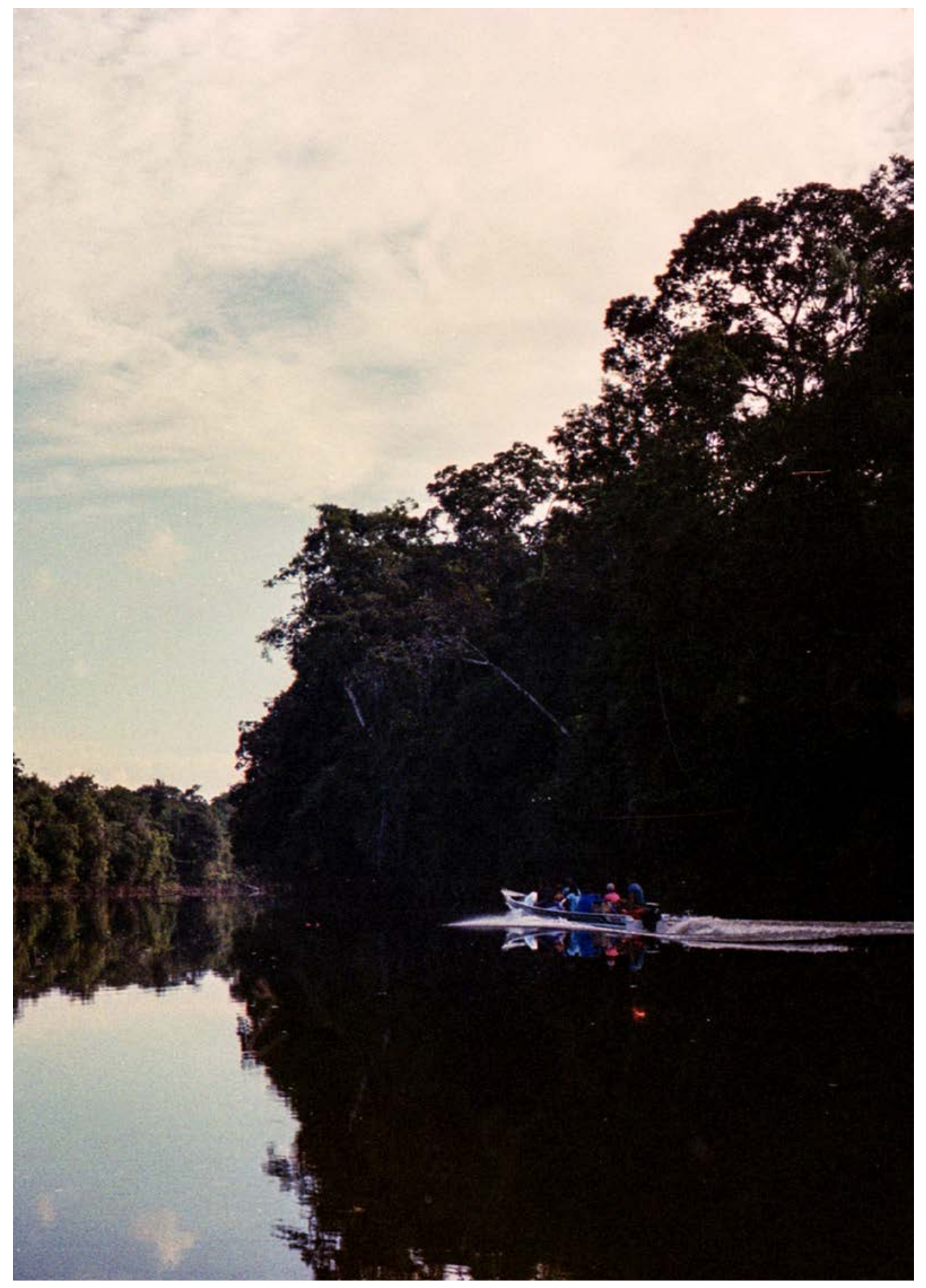

Fig. 75. Entardecer no Médio Rio Marauiá, registro durante nossa última viagem rio acima com os Pukimapiwëteri em 2020. 


\section{Referências}

Albert, Bruce. Temps du sang. Temps des cendres. Représentatrion de la maladie, systeme rituel et espace Politique chez les Yanomami du sud-est (Amazonie Brésilienne). 1985. Tese de Doutorado, Université de Paris X, Nanterre.

. Urihi: terra, economia e saúde Yanomami. In: Série Antropologia, n.119. Brasília: UNB, 1992. p. 1-20.

. "O ouro canibal e a queda do céu: uma crítica xamânica da economia política da natureza (yanomami)". Série Antropologia, Universidade de Brasília, n. 174, 1995. p. 1-33.

. "Native land: perspectives from other places". In: P. Virilio \& R. Depardon (orgs.). Native land: stop eject. Paris: Fondation Cartier pour l'art Contemporain, 2009. p. 37-58.

. "La fôret polyglotte". In: Le grand orchestre des animaux. Paris: Fondation Cartier pour l'Art Contémporain, p. 91-99.

. Sepultamento de Yanomami vítima da COVID-19. Amazônia Real, Manaus, 15 de abril de 2020. Disponível em: < https:// amazoniareal.com.br/sepultamento-de-yanomami-vitima-dacovid-19/>. Acesso em: 29/04/2020.

Albert, Bruce; Le Tourneau, François-Michel. "Ethnogeography and resource use among the Yanomami: toward a model of 'reticular space"'. Current Anthropology, vol. 48, n. 4, p. 584-592, 2007.

Albert, Bruce; Milliken, William. "The construction of a new yanomami round-house". Journal of Ethnobiology, n. 17, v. 2, p. 215-233, 1997.

Albert, Bruce; Milliken, William; Gomez, Gale Goodwin. Urihi a: a terra-floresta yanomami. São Paulo: ISA/IRD, 2009 [1999].

Alès, Catherine. "Anger as a marker of love. The ethic of conviviality among the Yanomami". In: Overing, Joanna; Passes, Alan. The Anthropology of Love and Anger. The Aesthetics of Conviviality in Native Amazonia. London/New York: Routledge, 2000. p. 133-151.

. "Función simbólica y organización social. Discursos rituales y política entre los Yanomami". In: Alès, Catherine; Chiappino, Jean (org.). Caminos Cruzados. Ensayos en Antropología Social, Etnoecología y Etnoeducación. Mérida: IRD Editions/ULA-GRIAL, 2003. p. 197.240.

Almeida, Mauro W. Barbosa de. "Caipora e outros conflitos ontológicos". Revista de Antropologia da UFSCar, v. 5, n. 1, p. 7-28, 2013. 
Andrello, Geraldo. "Transformações da cultura no Alto Rio Negro". In: Carneiro da Cunha, Manuela \& Cesarino, Pedro de Niemeyer (org.).

Políticas culturais e povos indígenas. São Paulo: Editora Unesp, 2014. p. 25-58.

Århem, Kaj. "From Longhouse to Village: Structure and Change in the Colombian Amazon". In: Rival, Laura; Whitehead, Neil (org.). Beyond the Visible and the Material - The Amerindianization of Society in the Work of Peter Rivière. Oxford: Oxford University Press, 2001. p. 123-156.

Ballester, Anne (org.). Naroriwë. O surgimento dos passáros. Ou o livro das transformações contadas pelos yanomami do grupo Parahiteri. São Paulo: Hedra, 2017a.

. Ruwëri. O surgimento da noite. Ou o livro das transformações contadas pelos yanomami do grupo Parahiteri. São Paulo: Hedra, 2017b.

Béksta, Kazys J. A maloca tukano-dessana e seu simbolismo. Manaus: Secretaria de Estado da Educação e Cultura, 1988.

Berbert, Paula. Tecendo redes de alianças afetivas: algumas notas sobre arte indígena contemporânea e práticas curatoriais. 2019. Trabalho de conclusão de curso, Pós-graduação em Estudos e Práticas Curatoriais da Fundação Armando Alvares Penteado, São Paulo.

Biocca, Ettore. Yanoáma: the story of Helena Valero, a girl kidnapped by Amazonian Indians. New York: Kodansha, 1996 [1965].

Blier, Suzane Preston. The anatomy of architecture: ontology and metaphor in Batammaliba architectural expression. Cambridge: Cambridge University Press, 1987.

Carneiro da Cunha, Manuela. "Pontos de vista sobre a floresta amazônica: xamanismo e tradução". Mana, n.4, v.1, p. 07-22, 1998.

Carsten, Janet; Hugh-Jones, Stephen (org.). About the house: LéviStrauss and beyond. Cambridge: Cambridge University Press, 1995.

Cesarino, Pedro de Niemeyer. "Donos e Duplos: relações de conhecimento, propriedade e autoria entre Marubo". Revista de Antropologia, n.1, v. 53, p. 147-197, 2010.

. Oniska: poética do xamanismo na Amazônia. São Paulo: Perspectiva/Fapesp, 2011.

Quando a terra deixou de falar - cantos da mitologia marubo. São Paulo: Editora 34, 2013. 
. "Conflitos ontológicos e especulações xamanísticas em La chute $\overline{\mathrm{du}}$ ciel de Davi Kopenawa e Bruce Albert". Sala Preta, n. 14. p. 205-212, 2014.

. "Montagem e formação do mundo nas artes verbais marubo". Species, n. 1, p. 66-78, 2015.

. "Imagens dobráveis: posição e ubiquidade nos xamanismos ameríndios". Boletim do Museu Paraense Emílio Goeldi, v. 14, n. 2, p. 499-511, 2019.

. "Poética e política nas terras baixas da América do Sul: a fala do chefe". Etnográfica, v. 24, p. 05-26, 2020.

Clastres, Hélène. "De que falam os índios". Cadernos de Campo, São Paulo, n. 25, p. 366-379, 2016 [2011].

Clastres, Pierre. A sociedade contra o Estado - pesquisas de antropologia política. São Paulo: Cosac Naify, 2003 [1974].

. Arqueologia da violência - pesquisas de antropologia política. São Paulo: Cosac Naify, 2004 [1980].

Clement, Charles R. "Domestication of the pejibaye palm (Bactris gasipaes): past and present”. In: Balick, Michal J. (ed.). The Palm - Tree of Life. Biology, Utilization and Conservation. New York: Advances in Economic Botany, vol. 6, 1988. p. 155-174.

Cocco, Luis. Iyëwei-teri. Quince años entre los yanomamos. Caracas: Escuela Técnica Popular Don Bosco, 1972.

Costa, Luiz Antonio. As Faces do Jaguar. Parentesco, História e Mitologia Entre os Kanamari da Amazônia Ocidental. 2007. Tese de doutorado, Museu Nacional, Rio de Janeiro.

De la Cadena, Marisol. Earth Beings: ecologies of practice across Andean worlds. Durham: Duke University Press, 2015.

Deleuze, Gilles; Guattari, Félix. Mil platôs. Capitalismo e esquizofrenia (vol.1). São Paulo: Editora 34, 1995 [1980].

Mil platôs. Capitalismo e esquizofrenia (vol.4). São Paulo:

Editora 34, 2012 [1980].

. Mil platôs. Capitalismo e esquizofrenia (vol.3). São Paulo:

Editora 34, 2015 [1980].

Fausto, Carlos. "Donos demais: maestria e domínio na Amazônia". Mana, n. 14, v.2, p. 329-366, 2008. 
Fox, James J. (org.). Inside Austronesian Houses: Perspectives on domestic designs for living. Canberra: The Australian National University Press, 2006.

Ferrari, Florencia et al. "O Apache era o meu reverso". Entrevista com Roy Wagner. Revista de Antropologia, Universidade de São Paulo, vol. 54, n.2, p. 955-978, 2012.

Gasparini, Graziano; Margolies, Luise. "La vivienda colectiva de los Yanomami". Tipití: Journal of the Society for the Anthropology of Lowland South America, n. 2, v. 2, p. 93-130, 2004.

Good, Kenneth. Yanomami hunting patterns: trekking and garden relocation as an adaptation to game availability in Amazonia, Venezuela. 1989. Tese de doutorado, University of Florida, Florida.

Gow, Peter. "Against the motion (2)". In: Ingold, Tim (ed.). Key Debates in Anthropology. London / New York: Routledge, 1996. cap. "1993 debate: Aesthetics is a cross-cultural category". p. 219-222.

An Amazonian Myth and its History. New York: Oxford University Press, 2001.

. “Me deixa em paz!' - Um relato etnográfico preliminar sobre o isolamento voluntário dos Mashco". Revista de Antropologia, Universidade de São Paulo, n.1, v.54, p. 11-46, 2011.

Guss, David. To Weave and Sing - Art, Symbol and Narrative in the South American Rain Forest. Berkeley: University of California Press, 1990.

Hamdan, Ana Amélia. Para escapar do coronavírus, Yanomami se refugiam no interior da floresta. Amazônia Real, Manaus, 28 de abril de 2020. Disponível em: <https://amazoniareal.com.br/para-escapardo-coronavirus-yanomami-se-refugiam-no-interior-da-floresta/ $>$. Acesso em: 29/04/2020.

Haraway, Donna; Torres, Helen. "Ficar com o problema de Donna Haraway - Entrevista”. Pandemia Crítica, n-1 edições, n. 137, p. 2-19, 2020.

Hugh-Jones, Christine. From the Milk River: Spatial and temporal processes in Northwest Amazonia. Cambridge: Cambridge University Press, 1979.

Hugh-Jones, Stephen. "The maloca: a world in a house". In: Carmichael, Elizabeth (org.). The hidden peoples of the Amazon. London: British Museum Publications, 1985. p. 78-93.

Ingold, Tim. The Perception of the Environment - Essays on livelihood, dwelling and skill. London: Routledge, 2000. 
. "Towards a Politics of Dwelling". Conservation and Society, n.2, v.3, p. 501-508, 2005.

Iramari Yanomami, Morzaniel; Machado, Ana Maria (org.). Xapiri thëa oni - Palavras escritas sobre os xamãs Yanomami. ISA/Hutukara: São Paulo/Boa Vista, 2014.

Ferreira, Helder Perri; Senra, Estêvão Benfica; Machado, Ana Maria Antunes (org.). As línguas Yanomami no Brasil: diversidade e vitalidade. São Paulo: Instituto Socioambiental, 2019. Disponível em: $<$ https://acervo.socioambiental.org/acervo/publicacoes-isa/linguasyanomami-no-brasil-diversidade-e-vitalidade $>$. Acesso em 15/06/2020.

Funai (Fundação Nacional do Índio). "Indígenas isolados do povo Yanomami foram registrados em operação da Funai". 09 de dezembro de 2016. Disponível em: <http://www.funai.gov.br/index. php/comunicacao/noticias/4046-isolados > . Acesso em: 25/06/2020.

Jabra, Daniel Stiphan. "Subir um rio de afetos". Capivara, n. 05, Dossiê Poesia de Quarentena, 2020. Disponível em: https://www. revistacapivara.com/poesia-de-quarentena-5. Acesso em: 17/09/2020.

Kopenawa, Davi; Albert, Bruce. "Xawara: o ouro canibal e a queda do céu - Depoimento de Davi Kopenawa". In: Yanomami: A todos os povos da terra. São Paulo: Ação pela Cidadania, 1990. pp. 11-4.

A queda do céu: palavras de um pajé yanomami. São Paulo: Companhia das Letras, 2015 [2010].

Kopenawa, Davi; Gomes, Ana Maria R. "O cosmo segundo os Yanomami: hutukara e urihi”. Revista da UFMG, n.1-2, v. 22, p. 142-159, 2015.

Kopenawa, Davi; Turner, Terence. "I fight because I am alive: an interview with Davi Kopenawa Yanomami”. Cultural Survival Quartely, n. 91, p. 59-64, 1991.

Krenak, Ailton. "Antes, o mundo não existia". In: Novaes, Adauto (org.) Tempo e História. São Paulo: Companhia das Letras, 1994, p. 201-204.

Krenak, Ailton; Cesarino, Pedro de Niemeyer. "As alianças afetivas Entrevista com Ailton Krenak por Pedro Cesarino". In: Volz, Jochen, Olascoaga, Sofia; Ngocobo, Gabi; Rebouças, Julia; Larsen, Lars Bang (org.). Incerteza viva - Dias de estudo: 32a Bienal de São Paulo. São Paulo: Fundação Bienal de São Paulo, 2016. v. 1, p. 169-189.

Krenak, Ailton; Massuela, Amanda; Weis, Bruno. "O tradutor do pensamento mágico - entrevista com Ailton Krenak. Revista Cult, n. 251, 2019. Disponível em: < https://revistacult.uol.com.br/home/ailtonkrenak-entrevista/> . Acesso em: 24/08/2020. 
Krenak, Ailton; Fernanda Santana. "'Vida sustentável é vaidade pessoal' - entrevista com Ailton Krenak". Jornal Correio, 25 de janeiro de 2020. Disponível em: <https://www.correio24horas.com.br/noticia/nid/ vida-sustentavel-e-vaidade-pessoal-diz-ailton-krenak/>. Acesso em: 24/08/2020.

Laudato, Luís. Yanomami pey këyo: o caminho yanomami. Brasilía: Editora Universa/Universidade Católica de Brasília, 1998.

Lévêque, Pierre; Vidal-Naquet, Pierre. Cleisthenes the Athenian - An Essay on the Representation of Space and Time in Greek Political Thought from the End of the Sixth Century to the Death of Plato. New Jersey: Humanities Press, 1997 [1964].

Lévi-Strauss, Claude. Tristes Trópicos. São Paulo: Companhia das Letras, 1996 [1955].

. "Hourglass configurations". In: Maranda, Pierra (ed.). The double twist. From ethnography to morphodynamics. Toronto: University of Toronto Press, 2001. cap. 1, p. 15-32.

. O cru e o cozido. São Paulo: Cosac Naify, 2004 [1964]. [1968]. A origem dos modos à mesa. São Paulo: Cosac Naify, 2006

. "A estrutura dos mitos". In: Antropologia estrutural. São Paulo: Cosac Naify, 2008 [1958]. cap. XI, p. 221-248.

. O homem nu. São Paulo: Cosac Naify, 2011 [1971].

. O pensamento selvagem. Campinas: Papirus, 2012 [1962].

. "A gesta de Asdiwal". In: . Antropologia estrutural dois. São Paulo: Cosac Naify, 2013 [1972]. cap. IX, p. 167-224.

Lizot, Jacques. Les Yanomami Centraux. Paris: Editions de l'Ecole Pratique de Hautes Etudes, 1984.

. O círculo dos fogos. Feitos e ditos dos índios Yanomami. São Paulo: Martins Fontes, 1988 [1976].

. "Words in the Night: The Cerimonial Dialogue - One Expression of Peaceful Relationships Among the Yanomami". In: Sponsel, Leslie E.; Gregor, Thomas (org.). The Anthropology of peace and nonviolence. Colorado: Lynne Rienner Publishers, 1994.

Diccionario enciclopédico de la lengua yãnomãmi. Puerto Ayacucho: Vicariato Apostólico de Puerto Ayacucho, 2004. 
. "El mundo intelectual de los yanomami: cosmovisión,

enfermedad y muerte con una teoría sobre el canibalismo". In: Freire, Germán (org.). Perspectivas en salud indígena: cosmovisión, enfermedad y políticas públicas. Quito: Ediciones Abya-Yala, 2011, p.141-190.

Lizot, Jacques; Cocco, Luís; Finkers, Juan. Los pueblos indios en sus mitos (vol. 4). Yanomami. Quito: Abya-Yala, 1993.

Low, Setha M.; Denise Lawrence-Zúñiga (org.). The anthropology of space and place: locating culture. Oxford: Blackwell Pub lishing, 2003.

Luciani, José Antonio Kelly. "Notas para uma teoria do 'virar branco'. Mana, n.11, v.1, p. 201-234, 2005.

State healthcare and yanomami transformations. A symmetrical ethnography. Tucson: The University of Arizona Press, 2011.

. "Aprendendo sobre os diálogos cerimoniais Yanomami". Species, n.1, v.1, p. 45-65, 2015.

. "On Yanomami ceremonial dialogues: a political aesthetic of metaphorical agency". Journal de la Société des américanistes, n.103, v.1, p.179-214, 2017.

Marchand, Trevor H. J. The Masons of Djenné. Bloomington: Indiana University Press, 2009.

Menezes, Gustavo Hamilton. Yanomami na encruzilhada da conquista: Contato e Transformação na fronteira amazônica. 2010. Tese de doutorado, Universidade de Brasília, Brasília.

Migliazza, Ernest Cesar. Yanomama grammar and intelligibility. 1972. Tese de Doutorado, Indiana University, Indiana.

Miranda, Tamara Aparecida. Os Yanomami do Rio Marauiá: trajetória e contato. 2020. Dissertação de Mestrado, Pontifícia Universidade Católica de São Paulo, São Paulo.

Nilsson, Maurice Seiji Tomioka; Fearnside, Philip Martin. "Yanomami Mobility and Its Effects on the Forest Landscape". Human Ecology, n.3, v.39, p. 235-256, 2011.

Novaes, Sylvia Caiuby (org.). Habitações indígenas. São Paulo: Edusp/ Nobel, 1983.

Perrone-Moisés, Beatriz. Festa e guerra. 2015. Tese de Livre-Docência, Universidade de São Paulo, São Paulo. 
Pierri, Daniel Calazans. O perecível e o imperecível: lógica do sensível e corporalidade no pensamento guarani-mbya. 2013. Dissertação de mestrado, Universidade de São Paulo, São Paulo.

Polykrates, Gottfried. Wawanautéri und Pukimapuei. Zwei Yanomamistämme nordwest-brasilien. Copenhagen: Publications of the National Museum of Denmark, Ethnographical series, vol. XIII, 1969.

Ramalho, Moisés. Os Yanomami e a morte. 2008. Tese de doutorado, Universidade de São Paulo, São Paulo.

Ramirez, Henri. Hapa të pë rë kuonowei. Mitologia Yanomami. Manaus: Inspetoria Salesiana da Amazônia, 1993.

. Le parler yanomami des Xamatauteri. 1994. Tese de Doutorado, Université de Provence, Aix-en-Provence.

Ramos, Alcida Rita. Memórias Sanumá - Espaço e tempo em uma sociedade Yanomami. São Paulo: Marco Zero, 1990.

Re, Giorgio; Re, Fabrizio; Laudato, Francisco; Laudato, Luís. Um mergulho na pré-história. Os últimos Yanomami?. Turim: Point Couleur, 1984.

Reig, Alejandro. 'When the forest world is not wide enough we open up many clearings'. The Making of Landscape, Place and People among the Shitari Yanomami of the Upper Ocamo basin, Venezuela. 2013. Tese de Doutorado, University of Oxford, Oxford.

Rivière, Peter. Individual and society in Guiana - A comparative study of Amerindian social organization. Cambridge: Cambridge University Press, 1984.

. "Houses, places and people: community and continuity in Guiana". In: Carsten, Janet; Hugh-Jones, Stephen (org.). About the house: Lévi-Strauss and beyond. Cambridge: Cambridge University Press, 1995. p. 189-205.

Smiljanic, Maria Inês. O corpo cósmico: o xamanismo entre os Yanomae do Alto Toototobi. 1999. Tese de Doutorado, Universidade de Brasília, Brasília.

. "Os enviados de Dom Bosco entre os Masiripiwëiteri. O impacto missionário sobre o sistema social e cultural dos Yanomami ocidentais (Amazonas, Brasil)". Journal de la société des américanistes, n. 88, p. 137-158, 2002.

Stengers, Isabelle. Cosmopolitics II. Minneapolis: University of Minnesota Press, 2011.

. No tempo das catástrofes - resistir à barbárie que se aproxima. São Paulo: Cosac Naify, 2015 [2009]. 
Strathern, Marylin. Partial Connections. Lanham: Altamira Press, 2004 [1991].

. "Prologue". In: Mosko, Mark S.; Damon, Frederick H (org.). On the order of chaos: social anthropology \& the science of chaos. New York/Oxford: Berghan Books, 2005. p. xii-xv.

O gênero da dádiva: problemas com as mulheres e problemas com a sociedade na Melanésia. Campinas: Editora Unicamp, 2013a [1988].

Learning to see in Melanesia - Lectures given in the Department of Social Anthropology, Cambridge University, 19932008. Cambridge: HAU Masterclass Series, vol.2, 2013b.

Taylor, Kenneth I. "A geografia dos espíritos: o xamanismo entre os Yanomami setentrionais". In: Langdon, Jean M. (org.). Xamanismo no Brasil. Novas perspectivas. Florianópolis: UFSC, 1996.

Urban, Greg. "Ceremonial dialogues in South America". American Anthropologist, v. 88, n. 02, p. 371-386, 1986.

Valero, Helena. Yo soy napëyoma: relato de una mujer raptada por los indígenas yanomami. Caracas: Fundación La Salle de Ciencias Naturales, 1984.

Vernant, Jean-Pierri. Mito e pensamento entre os Gregos. Rio de Janeiro: Paz e Terra, 1990 [1988].

Viveiros de Castro, Eduardo. A inconstância da alma selvagem e outros ensaios de antropologia. São Paulo: Cosac Naify, 2002.

. "Perspectival anthropology and the method of controlled equivocation”. Tipití, n. 1, vol. 2, p. 3-22, 2004.

"A floresta de cristal: notas sobre a ontologia dos espíritos amazônicos". Cadernos de Campo, n. 14/15, p. 1-382, 2006.

. Metafísicas Canibais: elementos para uma antropologia pósestrutural. São Paulo: Cosac \& Naify, 2015.

. "Nenhum povo é uma ilha". In: Ricardo, Fany; Gongora, Majoí. Cercos e resistências - povos indígenas isolados na Amazônia brasileira. São Paulo, ISA, 2019. p. 9-15.

Wilbert, Johannes; Simoneau, Karin (ed.). Folk literature of the Yanomami Indians. Los Angeles: University of California, 1990.

Zoé, Cafira. "Auscultar um rio: pequeno ensaio para uma cosmopolítica dos povos". Cadernos de subjetividade, n.19, ano 13, p. 69-74, 2019. 


